\title{
O IMPACTO NO BRASIL DA CASUÍSTICA INTERNACIONAL RELATIVA À VIOLACCÃO DO DIREITO DE INFORMAÇÃO SOBRE A ASSISTẾNCIA CONSULAR PARA PRESO ESTRANGEIRO
}

Dissertação de Mestrado

Orientador: Professor Associado PedRo BOHOMOLETZ DE ABREu DALlARI

Faculdade de Direito da Universidade de São Paulo

SÃo PAULO, 2011 


\title{
O IMPACTO NO BRASIL DA CASUÍSTICA INTERNACIONAL RELATIVA À VIOLAÇÃO DO DIREITO DE INFORMAÇÃO SOBRE A ASSISTENNCIA CONSULAR PARA PRESO ESTRANGEIRO
}

\begin{abstract}
Dissertação de Mestrado apresentada na Faculdade de Direito da Universidade de São Paulo como requisito para obtenção de título de Mestre Área de Concentração: Direito Internacional Orientador: PROFESSOR ASSOCIADO PEDRO BOHOMOLETZ DE ABREU DALLARI Departamento de Direito Internacional e Comparado (DIN-FDUSP)
\end{abstract}

FaCuldade de Direito da UniVersidade de São PaUlo

SÃo PAULO, 2011 
COMISSÃO JULGADORA:

Presidente: Professor Associado Pedro Bohomoletz DE ABREu DAllari

Julgamento:

Professor Titular Antonio Fernandes Scarance Julgamento:

Professor Doutor José RAUl GaViño DE AlMEIDA Julgamento:

FRANCISCO REZEK

Julgamento:

Suplente: Professor Doutor Wangner Menezes Julgamento:

Suplente: Professor Alexandre Wunderlich Julgamento: 
"A treaty is a contract between sovereigns. The notion that contracts must be enforceable against those who enter into them is fundamental to the Rule of Law. This case is resolved by that very basic idea. The United States voluntarily and legally entered into a treaty, a contract with over 100 other countries. The United States is bound by the terms of the treaty and the State of Oklahoma is obligated by virtue of the Supremacy Clause to give effect to the treaty." (Torres v. Oklahoma, No. PCD-04-442, slip. op. at 2-5, 8-12 (Ct. Crim. App. May 13, 2004)). Voto concordante do Juiz Charles S. Chapel.

"As Article 5 of the Convention makes plain, a principal function of the consular officer is to provide varying kinds of assistance to nationals of the sending State, and for this reason, the channel of communication between consular officers and nationals must at all times remain open. Indeed, such communication is so essential to the exercise of consular functions that its preclusion would render meaningless the entire establishment of consular relations. (...) Article 36 establishes rights not only for the consular officer but, perhaps even more importantly, for the nationals of the sending State who are assured access to consular officers and through them to others". Memorial apresentado pelos Estados Unidos em 12 de janeiro de 1980, no caso Teerã: Estados Unidos vs Irã, de 1979 (United States Diplomatic and Consular Staff in Tehran United States of America v. Iran), Memorial of the Government of the United States, p. 174.

"Um sul-africano tentou embarcar para Amsterdã, no Aeroporto Internacional de São Paulo, levando cinco quilos de cocaína no fundo falso de suas sandálias e numa cinta elástica presa ao corpo. Com um passaporte falso. Tudo passou despercebido até o momento do embarque. Só foi pego porque demonstrou nervosismo. Ele foi condenado em março de 2006. O tempo da condenação é a única informação que tem sobre o seu processo. Motivo: o sul-africano fala inglês e não conseguiu ler os fundamentos da sua condenação - só entendeu os números." Celas de Babel: ONG tenta defender o direito de defesa de estrangeiros. Instituto de Defesa do Direito da Defesa (IDDD). Disponível online em: $<$ http://iddd.org.br/imprensa/show/63>, (acesso em 02/11/2008).

"A expressão "residente no Brasil" deve ser interpretada no sentido de que a Constituição só pode assegurar a validade e o gozo dos direitos fundamentais dentro do território brasileiro." Habeas Corpus 74051/SC - Santa Catarina. Relator: Ministro Marco Aurélio. Julgado em 18/06/1996. Órgão Julgador: Segunda Turma. 
Para Dr. Hildebrando Bolivar e Myriancita, meus amados pais! 


\section{Agradecimentos}

Agradeço ao meu querido Mestre, o Professor Pedro Bohomoletz de Abreu Dallari, pelos ensinamentos e incentivo, mas, principalmente, por ter confiado em mim abrindo-me as portas da Faculdade de Direito da Universidade de São Paulo, de que tanto me orgulho de fazer parte.

Um agradecimento especial ao Professor Wagner Menezes, pelas orientações e inúmeras oportunidades acadêmicas a mim oferecidas, e quem me introduziu à participação dos eventos da Fundação Alexandre de Gusmão (FUNAG) e me apresentou ao querido Embaixador Jerônimo Moscardo. Muito obrigada pela sincera amizade!

Agradeço ao Embaixador Eduardo Gradilone Neto, Subsecretário-geral das comunidades brasileiras no exterior, do Ministério das Relações Exteriores; e à Secretária Adriana Telles Ribeiro, da Subsecretaria Geral das Comunidades Brasileiras no Exterior, pelo convite para participar da III Conferência "Brasileiros no Mundo" (CBM), realizada nos dias 2 e 3 de dezembro de 2010, com presença do Presidente da República no dia 3, no Palácio Itamaraty do Rio de Janeiro, e pelas informações tão úteis para a presente pesquisa.

Agradeço também aos meus amigos queridos da Academia, que compartilharam comigo os anseios das responsabilidades acadêmicas, como Maria Carla Coronel, Mariana Chaimovich, João Amorim, Adilson Paes de Souza. Ao meu querido tio Ney, pelo incentivo; ao meu irmão, pela amizade e conselhos; aos meus amados pais, pelo carinho e apoio incondicional durante a pesquisa, inclusive financeiro, e pela paciência, por haverem dividido a filha por tanto tempo com o computador, durante os raros encontros familiares em São Paulo. Finalmente, agradeço ao meu amor, Fernando Breviglieri, por todo apoio e compreensão durante a reta final deste trabalho. 


\section{RESUMO}

Trata-se do estudo da casuística internacional sobre as violações cometidas pelos Estados Unidos da América contra o artigo 36 da Convenção de Viena sobre Relações Consulares de 1963. A Corte Internacional de Justiça e a Corte Interamericana de Direitos Humanos interpretam, regulamentam e aprimoram o direito de informação sobre assistência consular para preso estrangeiro, que deixa de ser visto como um direito puramente inter-Estatal por ambos os tribunais. Abordamse questões de Direito Internacional Público, como a força vinculante das decisões da Corte Internacional de Justiça, e sua íntima relação com o direito interno do Estado parte do tratado, inclusive com relação aos Estados terceiros ao litígio internacional, como o Brasil. Em sendo um componente do pacote das garantias do devido processo legal, o prejuízo causado ao réu estrangeiro pela falta de informação sobre o direito de assistência consular pode ensejar o reconhecimento de nulidade processual penal absoluta.

\section{Palavras-chave}

Direito Internacional Público - Direito Internacional dos Direitos Humanos assistência consular para preso estrangeiro - Convenção de Viena sobre Relações Consulares de 1963 - processo penal 


\section{Abstract}

This is the study of international cases relating the violations committed by the United States of America against the article 36 of the Vienna Convention on Consular Relations of 1963. The International Court of Justice and the InterAmerican Court of Human Rights have the opportunity to interpret, regulate and enhance the right to information on consular assistance to foreign detainee, who is no longer seen as a purely inter-State law by both Courts. The study addresses issues of Public International Law, as the binding force of decisions of the International Court of Justice, and its close relationship with the Domestic Law of the State party to the treaty, including with respect to third states to the international dispute. Considered a human right, part of the package of guarantees of due process, the demonstrated prejudice caused to the foreign defendant for lack of information about his right to consular assistance may cause the recognition of absolute nullity of criminal procedure.

\section{KEY WORDS}

Public International Law - International Human Rights Law - consular assistance to foreign detainee - Vienna Convention on Consular Relations of 1963 - Criminal Procedural Law 
SUMÁRIO

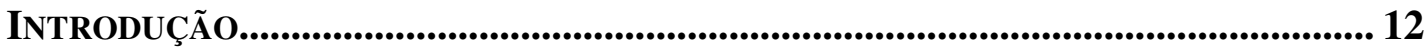

PARTe I - ENQUAdramento TEÓRICO DO DIREITO DE INFORMAÇÃo SOBRE ASSISTÊNCIA CONSULAR PARA PRESO ESTRANGEIRO.................. 25

Capítulo 1 - Breve contextualização histórica e doutrinária - da Antiguidade à Conferência das Nações Unidas sobre Relações Consulares................................ 26 Capítulo 2 - Qualificação do direito de informação sobre assistência consular para o preso estrangeiro

Parte II - Casuística internacional relativamente a Violações da CONVENÇÃo de VIENA SOBRE RELAÇÕES CONSUlaRES DE 1963........................... 59 Capítulo 3 - Introdução à escolha dos casos internacionais objeto do presente estudo 60

Capítulo 4 - Corte Internacional de Justiça - caso Breard: Paraguai vs. Estados Unidos da América, apresentado em 03 de abril de 1998, (Vienna Convention on Consular Relations - Paraguay v. United States of America) 73

4.1. A apresentação da controvérsia perante a Corte Internacional de Justiça.. 74 4.2. A medida provisória solicitada pelo Paraguai e ordenada pela Corte Internacional de Justiça 76

4.3. Contribuições do caso BREARD para o Direito Internacional Público. 80

Capítulo 5 - Corte Internacional de Justiça - Caso LaGrand: Alemanha vs. Estados Unidos da América, apresentado em 02 de março de 1999 .................. 83

5.1. Antecedentes do caso... 86

5.2. Curiosidades sobre o caso: a condição social dos irmãos LaGrand nos Estados Unidos.

5.3. A apresentação do contencioso pela Alemanha perante a Corte Internacional de Justiça e a ordem de medida provisória. 91 
Capítulo 6 - Corte Internacional de Justiça - Caso Avena: México vs. Estados Unidos da América, apresentado em 09 de janeiro de 2003 (Avena and Other Mexican Nationals - Mexico v. United States of America) 106

6.1. Quanto ao reconhecimento pela Corte Internacional de Justiça da previsão de direitos individuais pelo artigo 36 (1) (b) da Convenção de Viena sobre Relações Consulares de 1963 - e quanto à alegação de se tratar de um direito humano? 111

6.2. Quanto à interpretação da expressão "sem tardar", a partir de norma costumeira consagrada pela Convenção de Viena sobre Direito dos Tratados. 112

6.3. A posição dos Estados Unidos perante o Direito Internacional a partir da análise dos casos BREARD, LAGRAND E AVENA...... 115

Capítulo 7 - Corte Interamericana de Direitos Humanos - Opinião Consultiva Número 16 , de $1^{\circ}$ de outubro de 1999, solicitada pelo México, relacionada ao direito de informação sobre a assistência consular no âmbito das garantias do devido processo legal. 137

7.1. A Opinião Consultiva Número 16, de $1^{o}$ de outubro de 1999 da Corte Interamericana de Direitos Humanos.

7.2. Os efeitos causados pela Opinião Consultiva n. ${ }^{\circ} 16$ da Corte Interamericana de Direitos Humanos na esfera das Organizações Internacionais e no âmbito jurídico interno dos Estados. 150

7.3. A Opinião Consultiva Número 16 e seus efeitos no ordenamento jurídico brasileiro. 155

\footnotetext{
Parte III - Efeitos da Casuística internacional Relativa A ViOlaÇões da ConVEnÇÃo de Viena sobre RelaÇões ConSUlares DE 1963 NO DIREITO BRASILEIRO. 160
} 
Capítulo 8 - Reflexões sobre a relação entre direito internacional público e direito interno - efeitos das sentenças e pareceres jurídicos internacionais no direito brasileiro.

8.1. A incorporação dos tratados internacionais ao ordenamento positivo interno brasileiro - o status da Convenção de Viena sobre Relações Consulares de 1963. 168

8.2. Incorporação dos direitos previstos pelo artigo 36 da Convenção de Viena sobre Relações Consulares de 1963 no ordenamento positivo interno brasileiro análise da Constituição Federal e da legislação processual penal vigente. 183

Capítulo 9 - A assistência consular para preso estrangeiro como importante componente do direito de defesa: a ausência ou deficiência desse direito como causa de nulidade no processo penal...................................................................... 201

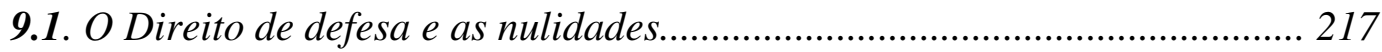

9.2. A hipótese de a violação do artigo 36 da Convenção de Viena sobre Relações Consulares de 1963 afetar o direito de ampla defesa à luz do Direito brasileiro.

9.3. A atuação do Brasil na assistência consular a brasileiros presos no exterior.

CONCLUSÃ̃

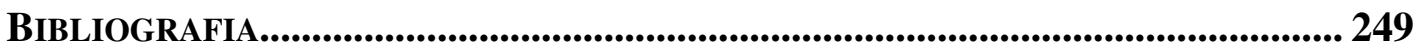

ANEXO I - ORGANOGRAMA DOS CASOS.............................................................261 


\section{INTRODUÇÃO}

O tema objeto deste trabalho de pesquisa acadêmica envolve o estudo dos casos contenciosos internacionais apresentados à Corte Internacional de Justiça, em face das violações cometidas pelos Estados Unidos da América contra o artigo 36 da Convenção de Viena sobre Relações Consulares de 1963, que codificou as normas costumeiras sobre o direito consular, além de ter estabelecido novos padrões. ${ }^{1}$ Inerentemente, tem também como base a Opinião Consultiva n..$^{\circ} 16$ de $1^{\circ}$ de outubro de 1999, solicitada pelo México à Corte Interamericana de Direitos Humanos. A partir da interpretação de ambos os tribunais internacionais, estuda-se a importância que o direito de informação sobre assistência consular representa para preso estrangeiro, em termos de Direito Internacional Público e, ainda, os efeitos das decisões no direito interno do Estado receptor do estrangeiro em situação de privação de liberdade, notadamente o direito processual penal. A referência, evidentemente, é o Brasil.

Apesar da área de concentração ser a do Direito Internacional, envolvendo a pesquisa questões como a auto-executabilidade de tratados internacionais e a força vinculante de decisões internacionais, este trabalho refere-se à relação da área com o direito interno, no caso o processo penal. Eis o que se prefere chamar de "viés interno" do Direito Internacional Público: a obrigação do Estado parte da Convenção de cumpri-la no âmbito processual penal, sob pena de sofrer uma responsabilização internacional.

E ainda relacionado a esse "viés interno" do Direito Internacional está o grande desafio, isto é, a reflexão sobre os efeitos das sentenças e pareceres jurídicos de tribunais internacionais no direito interno de Estados que, muito embora

\footnotetext{
1 "The VCCR codified existing international norms regarding consular relations and established new standards in the field. As such, the VCCR binds all States to the former through customary international law and binds signatory States, including the United States, to the latter by way of accession to the treaty." SHEIK, MANI. From Breard to Medellin: Supreme Court Inaction or ICJ Activism in the Field of International Law?, p. 535.
} 
não façam parte do litígio internacional, são partes do tratado em controvérsia, como, no caso, o Brasil. $^{2}$ Eis um dos resultados do próprio condensamento do Direito Internacional Público contemporâneo, com novos sujeitos e fontes, e vários foros para a busca de solução de controvérsias - decisões internacionais como fonte de interpretação do direito processual penal do Estado.

Tanto a Corte Internacional de Justiça quando a Corte Interamericana de Direitos Humanos tiveram a oportunidade histórica de interpretar e regulamentar o direito de informação sobre a assistência consular para preso estrangeiro, prevista pelo artigo 36 da Convenção de Viena sobre Relações Consulares de 1963. É assim que a casuística internacional, objeto desta pesquisa, representa uma grande contribuição para o aprimoramento e avanço desse direito. Isso porque, além de interpretarem e esclarecerem situações, esses tribunais internacionais indicam como esse direito deve ser aplicado pelo Estado Receptor, tanto perante o Estado de nacionalidade do indivíduo ("Estado que envia"), mas, principalmente, perante o próprio indivíduo, evitando-se uma responsabilização. As consequiências disso no plano jurídico interno dos Estados partes da Convenção fundamentam a última Parte do estudo. Daí outro fator importante e atual, que reflete o aumento do número de tribunais internacionais e a expansão dos seus poderes legais, um dos desenvolvimentos mais significativos no Direito Internacional do final do século XX - o surgimento de um sistema judiciário internacional com aparato cada vez mais forte.

Mais de treze anos depois de o Paraguai ter apresentado o primeiro pedido de abertura de procedimento contencioso perante a Corte Internacional de Justiça contra os Estados Unidos da América, em 03 de abril de 1998 - o caso BREARD; mais dez anos depois do julgamento pela Corte do caso interposto pela Alemanha - o caso LAGRAND, em 27 de junho de 2001; sete anos depois de a Corte

\footnotetext{
${ }^{2}$ A Convenção de Viena sobre Relações Consulares de 1963 foi celebrada em Viena, a 24 de abril de 1963. Assinada pelo Brasil em 24 de abril de 1963, foi provada pelo Decreto Legislativo $\mathrm{n}^{\circ}$ 6, de 1967. Teve o depósito de instrumento brasileiro de ratificação na ONU em 11 de maio de 1967, entrando em vigor, para o Brasil, a 10 de junho de 1967. Foi finalmente promulgada pelo Decreto $\mathrm{n}^{\circ}$ 61.078, de 26 de julho de 1967, e publicada no Diário Oficial de 28 de julho de 1967.
} 
Internacional de Justiça decidir sobre o último caso envolvendo a violação do artigo 36 da Convenção de Viena sobre Relações Consulares de 1963, apresentado pelo México em 09 de janeiro de 2003, o caso AvENA, a casuística internacional sobre violações do direito de informação e acesso à assistência consular, previsto no artigo 36 da Convenção de Viena sobre Relações Consulares de 1963, continua atraindo atenção.

Esses casos contenciosos envolvem estrangeiros que foram condenados à pena de morte por tribunais de diversos estados norte-americanos sem nunca terem sido, informados sobre o direito de informação e acesso à assistência consular (alguns deles até o foram, mas não oportunamente, conforme o direito processual penal americano, e sua doutrina Procedual Defaul). Alguns foram executados, como o paraguaio FrANCISCO BREARD, (estado da Virginia) o alemão Walter LaGrand (Arizona) e o mexicano José ERnesto Medelín (Texas), à margem das decisões de medidas provisórias e sentenças da Corte Internacional de Justiça. Além desses casos contenciosos, refere-se a Opinião Consultiva n. ${ }^{\circ} 16$, de 01 de outubro de 1999, da Corte Interamericana de Direitos Humanos.

O estudo da casuística internacional em questão permite a discussão de várias vertentes, como temas contemporâneos de Direito Internacional Público, tais como a força coercitiva das decisões da Corte Internacional de Justiça; a autoexecutoriedade da Carta das Nações Unidas; a relação entre Direito Internacional Público e direito interno dos Estados; o tema da multiplicação dos foros internacionais; além do crescente destaque da pessoa humana entre os sujeitos clássicos de Direito Internacional, ainda mais o foro em questão é tradicionalmente competente para julgar litígios apenas entre Estados. ${ }^{3}$ É nessa gama de sentidos que essa casuística foi escolhida, tanto no que representa em termos de Direito Internacional contemporâneo, como no contexto interno do Brasil - atuando como Estado Receptor e como Estado da nacionalidade do indivíduo preso no exterior, o Estado que envia. E, sobremaneira, no contexto do direito processual penal brasileiro.

\footnotetext{
${ }^{3} \mathrm{E}$ com relação a todas as questões de direito internacional que as partes a submetam, e a todos os assuntos especialmente previstos na Carta das Nações Unidas ou nos tratados e convenções vigentes. Artigos 34 e 36 do Estatuto da Corte Internacional de Justiça.
} 
Os casos contribuem para o aprimoramento e avanço do direito de notificação e acesso à assistência consular para o estrangeiro submetido a um ordenamento jurídico-criminal estranho, e privado de liberdade. Ambos os tribunais internacionais interpretam situações, esclarecem e indicam como esse direito deve ser cumprido pelo Estado Receptor, em seu plano jurídico interno, tanto perante o Estado que envia, mas, principalmente, perante o indivíduo.

Ao fornecer um quadro jurídico internacional para as relações consulares, privilégios e imunidades, a Convenção de Viena sobre Relações Consulares de 1963 visa assegurar o eficaz desempenho de funções pelas Repartições Consulares. Essas funções incluem, entre outras, a de promover o desenvolvimento de relações comerciais, econômicas, culturais e científicas entre o Estado que envia e o Estado Receptor, na qualidade de notário e registrador civil, na emissão de passaportes e documentos de viagem aos nacionais do Estado que envia, e de vistos e documentos apropriados às pessoas que pretendam viajar para o Estado de origem, prestar ajuda e assistência aos nacionais, pessoas físicas ou jurídicas, do Estado que envia.

Uma representação consular brasileira pode, por exemplo, indicar médicos, clínicas ou hospitais na região; orientar em caso de sepultamento, cremação no exterior ou de traslado de restos mortais para o Brasil. Nesse caso, a autoridade consular deverá ser informada imediatamente, a fim de que seja lavrado o óbito e emitido o atestado; repatriar cidadãos brasileiros que se encontrem no exterior, comprovada a extrema necessidade (desvalimento), mediante autorização do Ministério das Relações Exteriores e obedecidos os critérios estabelecidos pelo regulamento consular; pode também prestar informações sobre entidades assistenciais e condições de trabalho; facilitar o contato com familiares e amigos ou alguém que lhe possa prestar ajuda, com o envio de recursos financeiros, documentos e passagens; informar os parentes mais próximos, em caso de acidente ou outras emergências, e orientá-los quanto aos procedimentos adequados. Mas as funções do funcionário consular ${ }^{4}$ não param por aí. Incluem ainda a de representar os nacionais

\footnotetext{
${ }^{4}$ A Convenção de Viena sobre Relações Consulares define como "funcionário consular" como sendo "toda pessoa, inclusive o chefe da repartição consular, encarregada nesta qualidade do exercício de
} 
do Estado que envia e tomar as medidas convenientes para sua representação perante os tribunais e outras autoridades do Estado Receptor, visando conseguir, de acordo com as leis e regulamentos desse, a adoção de medidas para a salvaguarda dos direitos e interesses de seus nacionais, quando, por estarem ausentes ou por qualquer outra causa, não possam esses se defender em tempo útil. A razão subjacente da proteção consular é que o cônsul, ao se comunicar com seus nacionais, pode garantir o respeito aos direitos humanos fundamentais de seu nacional, confirmar a integridade física e estado mental saudável do seu compatriota naquela situação vulnerável, bem como verificar que não houve violação dos direitos (por exemplo, força, excesso de prisão, coerção para confissão e outros). O funcionário consular ainda pode informar sobre a existência de serviços locais de assistência jurídica gratuita; sugerir advogados locais que possam orientar sobre serviços jurídicos; e

funções consulares". "Cônsul" é uma das categorias de chefes da repartição consular. O artigo $5^{\circ}$ da Convenção qualifica as funções do Cônsul: "As funções consulares consistem em: a) proteger, no Estado receptor, os interesses do Estado que envia e de seus nacionais, pessoas físicas ou jurídicas, dentro dos limites permitidos pelo direito internacional; b) fomentar o desenvolvimento das relações comerciais, econômicas, culturais e científicas entre o Estado que envia e o Estado receptor e promover ainda relações amistosas entre eles, de conformidade com as disposições da presente Convenção; (c) informar-se, por todos os meios lícitos, das condições e da evolução da vida comercial, econômica, cultural e científica do Estado receptor, informar a respeito o governo do Estado que envia e fornecer dados às pessoas interessadas; d) expedir passaportes e documentos de viagem aos nacionais do Estado que envia, bem como vistos e documentos apropriados às pessoas que desejarem viajar para o referido Estado; e) prestar ajuda e assistência aos nacionais, pessoas físicas ou jurídicas do Estado que envia; f) agir na qualidade de notário e oficial de registro civil, exercer funções similares, assim como outras de caráter administrativo, sempre que não contrariem as leis $e$ regulamentos do Estado receptor; g) resguardar, de acordo com as leis e regulamentos do Estado receptor, os interesses dos nacionais do Estado que envia, pessoas físicas ou jurídicas, nos casos de sucessão por morte verificada no território do Estado receptor; h) resguardar, nos limites fixados pelas leis e regulamentos do Estado receptor, os interesses dos menores e dos incapazes, nacionais do país que envia, particularmente quando para eles for requerida a instituição de tutela ou curatela; $i$ ) representar os nacionais do país que envia e tomar as medidas convenientes para sua representação perante os tribunais e outras autoridades do Estado receptor, de conformidade com a prática e os procedimentos em vigor neste último, visando conseguir, de acordo com as leis e regulamentos do mesmo, a adoção de medidas provisórias para a salvaguarda dos direitos e interesses destes nacionais, quando, por estarem ausentes ou por qualquer outra causa, não possam os mesmos defendê-los em tempo útil; j) comunicar decisões judiciais e extrajudiciais e executar comissões rogatórias de conformidade com os acordos internacionais em vigor, ou, em sua falta, de qualquer outra maneira compativel com as leis e regulamentos do Estado receptor; $k$ ) exercer, de conformidade com as leis e regulamentos do Estado que envia, os direitos de controle e de inspeção sobre as embarcações que tenham a nacionalidade do Estado que envia, e sobre as aeronaves nele matriculadas, bem como sobre suas tripulações; l) prestar assistência às embarcações e aeronaves a que se refere a alínea " $k$ " do presente artigo e também às tripulações: receber as declarações sobre as viagens dessas embarcações, examinar e visar os documentos de bordo e, sem prejuízo dos poderes das autoridades do Estado receptor, abrir inquéritos sobre os incidentes ocorridos durante a travessia e resolver todo tipo de litígio que possa surgir entre o capitão, os oficiais e os marinheiros, sempre que autorizado pelas leis e regulamentos do Estado que envia; $m$ ) exercer todas as demais funções confiadas à repartição consular pelo Estado que envia, as quais não sejam proibidas pelas leis e regulamentos do Estado receptor, ou às quais este não se oponha, ou ainda as que lhe sejam atribuídas pelos acordos internacionais em vigor entre o Estado que envia e o Estado receptor." 
informar, desde que autorizado pelo preso, o fato a seus familiares no Estado que envia.

Nesses termos, a Convenção de Viena de 1963 contribui para o desenvolvimento de relações entre as nações, tendo em conta os objetivos e princípios da Carta das Nações Unidas, em particular os relativos à igualdade soberana dos Estados, a manutenção da paz internacional e segurança e a promoção de relações amistosas entre as nações. ${ }^{5}$

O estrangeiro submetido a um procedimento penal, em especial quando privado de liberdade, deve contar com medidas que lhe permitam um verdadeiro e pleno acesso à justiça. Deve comparecer em pé de igualdade com os nacionais do Estado em que segue o juízo, perante a justiça, sem as graves limitações que implicam a estranheza cultural, a ignorância do idioma, o desconhecimento do sistema processual e outras restrições de suas possibilidades de defesa. São necessárias vias de compensação que garantam o pleno acesso à justiça e conteúdo real ao devido processo legal. São nesses direitos e garantias que integram o devido processo legal - um sistema dinâmico, em constante formação - que está o direito do preso estrangeiro de ser informado sobre o direito que possui de recorrer à proteção consular e, concomitantemente, o de o Estado de sua nacionalidade ser notificado da prisão de seu súdito, por meio de sua representação diplomática que é o Consulado. ${ }^{6}$

O Brasil é parte da Convenção de Viena sobre Relações Consulares de 1963. Portanto, tem a obrigação de respeitar seus preceitos internamente, enquanto Estado Receptor, devendo, assim, facilitar o exercício das funções consulares relativas aos nacionais do Estado que envia, sempre que esses indivíduos forem presos, encarcerados, postos em prisão preventiva ou detidos de qualquer outra maneira em sua jurisdição, nos termos dos artigos $5^{\circ}$ e $36^{\circ}$ da Convenção de Viena de 1963.

\footnotetext{
${ }^{5} \mathrm{O}$ decreto $\mathrm{n}^{\circ} 19.841$, de 22 de outubro de 1945. promulga a Carta das Nações Unidas, da qual faz parte integrante o anexo Estatuto da Corte Internacional de Justiça, assinada em São Francisco, a 26 de junho de 1945, por ocasião da Conferência de Organização Internacional das Nações Unidas.

${ }^{6}$ Opinión Consultiva OC-16/99 del 1 de octubre de 1999. El Derecho a la Información sobre la Asistencia Consular en el Marco de las Garantías del Debido Proceso Legal, Voto concordante do JUIZ SÉRGIO GARCIA RAMIREZ, pp. 02 e 03.
} 
Enquanto Estado que envia, o Brasil tem o direito de exigir o exercício do direito de informação sobre assistência consular e acesso aos nossos compatriotas detidos de qualquer maneira no exterior quando esses indivíduos não recusarem o acesso. Aqui, em termos de assistência consular, o tema apresentado na última Parte será a atuação desempenhada pelo Ministério das Relações Exteriores, quanto à assistência consular aos nossos compatriotas detidos no exterior.

O desafio central do presente trabalho é o estudo dos efeitos da casuística internacional estudada no direito processual penal brasileiro. No caso de o Brasil, atuando como Estado Receptor, por meio de suas autoridades competentes, deixar de informar os estrangeiros que aqui se encontram detidos, de qualquer maneira, sobre o direito deles de informação sobre assistência consular. A problemática consiste em tentar responder até que ponto poderia essa violação acarretar o prejuízo da ampla defesa do acusado estrangeiro a ponto de acarretar uma nulidade processual.

Por outro lado, em termos de Direito Internacional Público, o desafio consiste em identificar quais seriam os efeitos dessas decisões no Direito doméstico do Brasil eis que, muito embora seja parte da Convenção de Viena de 1963, não participou das controvérsias internacionais, e tampouco reconhece a jurisdição compulsória da Corte Internacional de Justiça. Nesse contexto, é possível questionar, no decorrer da pesquisa, quais seriam então os efeitos das sentenças da Corte Internacional de Justiça com relação a terceiros Estados como o Brasil. Poderiam interpretar e aplicar internamente entendimento diverso ao reconhecido pela Corte Internacional de Justiça? No caso do Brasil, seria este um efeito análogo ao das Opiniões Consultivas como os da Corte Interamericana de Direitos Humanos, cuja jurisdição compulsória o Brasil reconhece? E mais, ainda nesse âmbito internacional, poderia o Brasil reclamar a violação do direito de assistência consular para seus nacionais detidos no exterior, que não tiverem sido informados oportunamente sobre esse direito, tendo sua ampla defesa prejudicada haja vista toda a atmosfera de vulnerabilidade que nossos compatriotas se encontram nessa situação? 
As principais questões a serem analisadas no decorrer desta dissertação de Mestrado envolvem vertentes não única e exclusivamente de Direito Internacional Público, tais como os efeitos causados pela ratificação de tratados internacionais no ordenamento jurídico-criminal interno dos Estados. In casu, o protagonista é um tratado não caracteristicamentede direitos humanos, mas que cria direitos individuais - o direito de informação sobre a assistência consular para preso estrangeiro. O tema escolhido traz importantes lições para o Brasil, por ser parte da Convenção de Viena sobre Relações Consulares, sobre o avanço do exercício da assistência consular no país, tanto para os estrangeiros que aqui se encontram enfrentando procedimentos criminais, e estando privados de liberdade, como com relação aos brasileiros que se encontram no exterior, enfrentando sistemas criminais desconhecidos, em cultura e língua desconhecida. Oferecerá também uma oportunidade para salientar essa importante função consular.

A partir da busca pela respostas aos problemas jurídicos teóricos, a pesquisa apresenta como resultado importantes lições práticas tanto em termos de Direito Internacional Público, como para o Direito brasileiro, e está dividido em três Partes e nove capítulos. O ponto de partida, a Parte I, dedica-se ao estudo teórico, ou seja, um sintético enquadramento histórico sobre a assistência consular, um costume internacional que existe desde os primórdios da sociedade humana organizada, que possui uma miríade de funções, entre as quais, a assistência consular para o indivíduo privado de liberdade em Estados Receptores afora. Uma interessante e breve diferenciação entre os papéis de uma missão diplomática (Embaixada) e de uma repartição consular, e entre os respectivos agentes diplomáticos e funcionários consulares, é inerente ao estudo proposto neste momento da pesquisa. Aqui, o método dedutivo e indutivo é primordialmente utilizado. O método dedutivo será a ferramenta principal quando uma construção ideal tiver de ser intentad, na procura de transformar enunciados complexos em particulares, cujo conhecimento embutido na conclusão já existe nas premissas. Ou seja, por meio do estudo da casuística internacional, bem como a leitura da doutrina, artigos científicos, e do marco regulatório internacional, leis nacionais e o estudo da relação entre esses chegaremos à conclusão de que, em sendo o Brasil parte da Convenção de Viena sobre Relações Consulares de 1963, tem a obrigação internacional de cumprir com seus preceitos em 
seu ordenamento jurídico interno, ou seja, de informar o estrangeiro preso em sua jurisdição, assim como notificar o consulado da nacionalidade desse estrangeiro, sobre sua situação, e da forma como a Corte Internacional de Justiça estipula, mas na medida conforme consagrado nos casos LAGRAND e AVENA - assim que ficar claro que se trata de um estrangeiro em situação de privação de liberdade.

A Parte II é dedicada ao estudo dos casos internacionais sobre violações cometidas pelos Estados Unidos da América contra o artigo 36 da Convenção de Viena sobre Relações Consulares, e a consequiência disso no plano jurídico internacional. Questões clássicas de Direito Internacional Público são visitadas, como a força vinvulante de tratados internacionais no âmbito interno dos Estados. Neste momento da pesquisa, aplica-se o método dedutivo, indutivo e comparatista ao analisarem-se os três casos levados perante a Corte Internacional de Justiça sobre violações cometidas contra a Convenção de Viena sobre Rlações Consulares de 1963; decisões clássicas da Suprema Corte norte-americana, e Cortes estaduais, com seus argumentos de direito interno para a não implementação das sentenças da Corte Internacional de Justiça. Um paralelo é apresentado com o caso dos Reféns em Teerã (United States Diplomatic and Consular Staff in Tehran United States of America v. Iran), e outras decisões internacionais, que observam a tímida mudança de perspectiva que está em curso na Corte Internacional de Justiça. Sem falar do Parecer Parecer Consultivo n. ${ }^{\circ} 16$ da Corte Interamericana de Direitos Humanos, que reconhece que o direito garantido pelo art. 36, 1(b) da Convenção de Viena sobre Relações Consulares de 1963 está entre as garantias mínimas essenciais para fornecer ao preso estrangeiro a oportunidade para preparar sua defesa e receber um julgamento justo adequadamente, eis que se trata de um direito humano fundamental componente do devido processo legal em caso de o preso estrangeiro.

Na Parte III estudam-se os efeitos dessa casuística internacional no Direito processual penal brasileiro. É aqui que se visa identificar a internalização dos preceitos do artigo 36 da Convenção de Viena de 1963 às regras constitucionais e de direito processual penal brasileiro: o direito de informação e acesso à assistência consular para preso estrangeiro como sendo um importante componente à efetivação do exercício da ampla defesa, podendo sua ausência ou deficiência, resultar em uma 
eventual causa de nulidade, haja vista o eventual prejuízo das garantias mínimas do devido processo legal. Finalmente, a conclusão será no sentido de reforçar a importância do tema escolhido, que oferece importantes reflexões e lições, tanto em termos de Direito Internacional Público, como em termos de direito interno, notadamente o brasileiro.

É possível constatar ainda que o estudo da casuística internacional objeto do presente trabalho também reflete uma tímida mudança de perspectiva da Corte Internacional de Justiça. Nas decisões dos casos LAGRAND e AvENA, a Corte, por meio da interpretação literal do artigo 36 da Convenção de Viena sobre Relações Consulares de 1963, reconheceu a existência de uma "circunstância especial de interdependência" entre direitos individuais e direitos do Estado que envia. ${ }^{7}$ Seria um possível destaque do indivíduo em foro internacional tradicionalmente interEstatal, uma aparente e discutível resistência ao voluntarismo positivista Westphaliano, que nega o jus standi aos indivíduos, dificultando a própria compreensão do Direito Internacional como um sistema verdadeiramente universal que deveria ser. ${ }^{8}$

FRANCISCO REZEK ${ }^{9}$, quanto à personalidade internacional, defende que pessoas de Direito Internacional Público são os Estados soberanos (personalidade originária de Direito Internacional Público) e as organizações internacionais em sentido estrito. No entanto, ele afirma que essa não é uma verdade eterna, mas uma

\footnotetext{
7 "The Court would recall that, in the LaGrand case, it recognized that "Article 36, paragraph 1 [of the Vienna Convention], creates individual rights [for the national concerned], which. . . may be invoked in this Court by the national State of the detained person" (I.C.J. Reports 2001, p. 494, para. 77). It would further observe that violations of the rights of the individual under Article 36 may entail a violation of the rights of the sending State, and that violations of the rights of the latter may entail a violation of the rights of the individual. In these special circumstances of interdependence of the rights of the State and of individual rights, Mexico may, in submitting a claim in its own name, request the Court to rule on the violation of rights which it claims to have suffered both directly and through the violation of individual rights conferred on Mexican nationals under Article 36, paragraph 1 (b)." Case concerning Avena and other Mexican nationals (Mexico $v$. United States of America), ICJ Reports of Judgments, Advisory Opinions and Orders (05/02/2003), parágrafo 40.

${ }^{8}$ CANÇADO TRINDADE, Antônio Augusto. Tratado de Direito Internacional dos Direitos Humanos, pp. $447-448$ e 453.

${ }_{9}^{9}$ REZEK, Francisco. Direito Internacional. Curso Elementar, pp. 154 e 159. O Ministro ressalta que o próprio Estatuto do Tribunal Penal Internacional confirma a falta de relação imediata entre o indivíduo e o direito das gentes, eis que o exercício efetivo da jurisdição do tribunal pressupõe o consentimento - a condição de parte da Convenção de Roma de 17/07/1998 - seja um consetimento ad hoc - tanto do Estado territorial do crime quanto do Estado patrial do réu.
} 
dedução da cena internacional contemporânea. Para ele, os indivíduos não têm personalidade internacional, tampouco as empresas privadas e públicas. Isso porque, esses entes não se envolvem na produção do acervo normativo internacional, tampouco guardam relação direta com essa ordem. De fato, os indivíduos não possuem ampla prerrogativa para reclamar a garantia de seus direitos em foros internacionais, mas submetem-se, para isso, ao compromisso estatal tópico, o que depende de um Estado "co-patriocinador do foro, de um vínculo jurídico de sujeição, em regra o vínculo de nacionalidade." É também experimental a idéia de que o direito das gentes imponha obrigações diretamente aos indivíduos.

Todavia, não há como negar as profundas transformações pelas quais tem passado o Direito Internacional nas últimas cinco décadas, como sistema de ordenação das relações entre sujeitos de Direito Internacional, sobretudo diante do gradativo destaque da pessoa humana vis a vis seu próprio Estado. ${ }^{10} \mathrm{O}$ antigo monopólio estatal da titularidade de direitos não encontra mais a mesma força e, gradativamente, o Direito Internacional enfrenta a necessidade de resgatar valores universais.

A construção do Direito Internacional no contexto pós-moderno está em curso. Trata-se de situá-lo no contexto histórico e cultural da atualidade, de forma a posicionar seus fundamentos na regulação da convivência entre os sujeitos clássicos de Direito Internacional, e os que estão posicionando-se. Deve tomar como parâmetro a realidade do mundo. É repensar as bases e conceitos herdados pelo Direito Internacional de outros tempos, e seu arcabouço normativo e conceitual,

\footnotetext{
${ }^{10}$ Para CANÇADO TRINDADE, os positivistas chegaram a identificar os princípios fundamentais do direito, que inspiram e conformam suas normas, como se deles emanassem. Daí, eles desvendaram uma visão estática do mundo, ignorando por completo sua dimensão temporal. Isolaram o Direito de outras áreas do conhecimento, revelando uma auto-suficiência própria dos arrogantes. É até confortável ser positivista ou realista, eis que não exige erudição alguma, tampouco maiores conhecimentos. Na era das Nações Unidas, os positivista-voluntaristas só conseguem enxergar interesses e vantagens, e não parecem crer na razão humana, e nem na capacidade dos seres humanos de extrair lições da experiência histórica. CANÇADO TRINDADE, Antônio Augusto. A Recta Ratio nos Fundamento do Jus Gentium como Direito Internacional da Humanidade. In: A Humanização do Direito Internacional, pp. 21 e 25.
} 
levando-se em conta outros agentes e os dados históricos e culturais, de maneira mais abrangente. $^{11}$

É nesse contexto contemporâneo que se insere o direito de informação sobre a assistência consular para preso estrangeiro no universo conceitual dos direitos humanos - a Corte Interamericana de Direitos Humanos concluiu que os direitos dispostos no artigo 36 da Convenção de Viena sobre Relações Consulares de 1963, não pode mais ser dissociado do corpus iuris dos direitos humanos, como componente das garantias do devido processo legal. ${ }^{12}$

A Corte Internacional de Justiça preferiu interpretar o sentido do direito de informação sobre assistência consular para preso estrangeiro como sendo um direito individual, ao invés de enfrentar suas próprias amarras positivistavoluntaristas. Por outro lado, foi sim um considerável avanço ao ressaltar que, poderia considerá-lo um direito humano, haja vista que isso seria uma questão de interpretação do tratado, para o qual possui competência.

Esta pesquisa também envolve o diálogo entre a Corte Interamericana de Direitos Humanose a Corte Internacional de Justiça. Uma busca da coerência do Direito Internacional ora especializado. É nesse contexto que se busca identificar a contribuição desses tribunais internacionais para o tema do direito de notificação e informação sobre a assistência consular para preso estrangeiro. Ainda, sua importância para a garantia do devido processo legal, no que diz respeito ao direito de ampla defesa, uma condição da paridade de armas que é imprescindível à concreta atuação do contraditório e, assim, à própria imparcialidade do juiz.

\footnotetext{
${ }^{11}$ CaSella, Paulo Borba. Fundamentos do Direito Internacional Pós-Moderno, pp. 15 -17. Nesse sentido, para o Juiz da Corte Internacional de Justiça, resgatar, neste início de século XXI, o legado do Jus Gentium em evolução equivale a sustentar a concepção universalista do Direito Internacional, voltada ao mundo em que vivemos, dilacerado por conflitos e disparidades, de modo a tornar o Direito Internaiconal capaz de responder às necesidades e aspirações da humanidade na atualidade. In: Cançado Trindade, Antônio Augusto. A Recta Ratio nos Fundamento do Jus Gentium como Direito Internacional da Humanidade. In: A Humanização do Direito Internacional, p. 15.

${ }^{12}$ CANÇADO TRINDADE, Antônio Augusto. Voto concordante. Opinião Consultiva n. ${ }^{\circ} \mathbf{1 6} / 99$, de $1^{\mathbf{0}}$ de outubro de 1999, solicitada pelos Estados Unidos Mexicanos perante a Corte Interamericana de Direitos Humanos. O direito à informação sobre a assistência consular no âmbito das garantias do devido processo legal, parag. 15.
} 
Esse será o quadro proposto: a relação entre o Direito Internacional Público e o ordenamento jurídico criminal interno. O direito de informação sobre assistência consular importa para a efetivação do devido processo legal, no sentido de que o acusado não pode ser condenado sem que, antes, tenha podido exercer, com plenitude, a sua defesa. Daí a necessidade de haver procedimentos com atos e fases que permitam ao acusado impedir que prossiga o processo contra ele e, de responder à acusação infundada, provar as suas alegações e recorrer de decisões condenatórias, e alegar prejuízo à defesa por conta da ausência de informação sobre assistência consular. $^{13}$

A casuística internacional que embala a pesquisa, além de identificar o avanço oferecido pelos tribunais internacionais quanto à interpretação e aplicação interna do direito de informações sobre a assistência consular para preso estrangeiro, apresenta fatos que sugerem que a evolução do Direito Internacional está em curso. Conceitos de justiça operacionalmente válidos, condições, valores universais, princípios fundamentais são todos repaginados, reinventados, reinterpretados, permanecendo válidos. O Direito Internacional contemporâneo reassume que existem regras, princípios e valores que se situam acima da livre-vontade do Estado. É o que CANÇADO TRINDADE refere ser o "eterno retorno do jusnaturalismo", contribuindo à afirmação e consolidação do primado internacional na ordem dos valores objetivos universais, das obrigações em matéria de direitos humanos vis a vis a comunidade internacional como um todo: trata-se da revitalização dos próprios princípios e fundamentos do Direito Internacional, que o estudo da casuística em questão instiga à reflexão. ${ }^{14}$

\footnotetext{
${ }^{13}$ Fernandes, Antonio Scarance; ALMEIDA, José Raul Gavião de; MoraES, Maurício Zanoide de. Sigilo no Processo Penal: Eficiência e Garantismo, p.14.

${ }_{14}$ CANÇADO TRINDADE, Antônio Augusto. A formação do Direito Internacional Contemporâneo: reavaliação crítica da teoria clássica de suas fontes. A Humanização do Direito Internacional, p. 86.
} 
PARTe I

ENQUADRAMENTO TEÓRICO DO DIREITO DE INFORMAÇÃo SOBRE ASSISTÊNCIA CONSULAR PARA PRESO ESTRANGEIRO 


\section{Capítulo 1}

\section{BREVE CONTEXTUALIZAÇÃo HiStóRICA E DOUTRINÁRIA - DA ANTIGUIDADE À CONFERÊNCIA DAS NAÇÕES UNIDAS SOBRE RELAÇÕES CONSULARES}

Nesta etapa inicial o propósito é apresentar um breve enquadramento teórico-histórico sobre o direito de assistência consular e a miríade de atribuições do funcionário consular, cuja assistência prestada ao súdito preso em Estado Receptor afora, objeto primordial do presente trabalho, é apenas uma das que atua. A assistência consular é um costume internacional que existe desde a Antiguidade, aqui, realiza-se uma apresentação histórica do papel do cônsul no desenvolvimento da sociedade internacional organizada, e a importância de sua atuação na proteção dos direitos dos indivíduos que se encontram no exterior, geralmente em situação de maior vulnerabilidade com relação aos nacionais. A partir da contextualização histórica, identificam-se institutos que se assimilavam ao papel desenvolvido pelo cônsul atual.

A Convenção de Viena sobre Relações Consulares de 1963 codificou as normas costumeiras que há muito regiam a atuação consular, e estabeleceu novos padrões nesse campo. ${ }^{15}$ Isso porque, o Direito Consular possui uma história mais

\footnotetext{
${ }^{15}$ A adoção da Convenção de Viena de 1961 sobre Relações Diplomáticas de 1963 e Convenção de Viena sobre Relações Consulares, seguido por sua grande aceitação pelos Estados-membros da comunidade internacional, foi logo sendo contada como um marco na codificação do Direito Internacional moderno. Seu sucesso foi atribuído ao fato de pertencerem a um domínio clássico do Direito Internacional, que já contava, antes mesmo da sua aprovação, com a prática considerável dos Estados. Foi também atribuído por pertencer à condução do Estado, ao invés da "substância das relações inter-Estatais". As citadas convenções foram consideradas como sendo "declaratórias" do direito consuetudinário sobre o tema. $\mathrm{Na}$ época em que foram adotadas e entraram em vigor, a implementação de ambas era encarada pelo panorama estritamente inter-Estatal. Menos de duas décadas depois, a CIJ, no caso "Estados Unidos vs. Irã", chamando atenção comunidade internacional como um todo, considerou que, ao menos quanto a alguns dispositivos, e os próprios EUA afirmaram em seu Memorial, "padrões de direitos humanos aceitáveis", e que o artigo 36 da CVRC consagra direitos humanos. CANÇADO TRINDADE, Antonio Augusto. International Law for Humankind: towards a New Jus Gentium (II), pp. 130-1.
} 
antiga e variada que as próprias missões diplomáticas. No decorrer dos séculos, os postos consulares desenvolveram uma grande variedade de tarefas - diplomática, política, comercial, jurídica, marítima - todas deixando sua marca na atividade do cônsul moderno. Ao gerar um sentido de confiança conducente ao comércio, viagens, residência em terras estrangeiras, o cônsul adquiriu a devida importância hoje reconhecida. $^{16}$

Daí porque dizer que a história das relações consulares é uma prova a mais para a observação de ROBERTO $\mathrm{AGO}^{17}$ sobre o Direito Internacional, “de que o direito inter-Estatal é quase tão antigo quanto o direito das sociedades quaseEstatais; na verdade um fenômeno que sempre emergiu e se desenvolveu entre um grupo de entidades políticas distintas e soberanas, sempre que relações continuadas e organizadas vieram a existir entre si." O próprio Preâmbulo da Convenção de Viena de 1963 evidencia isso, ao considerar que "desde tempos remotos, se estabeleceram relações consulares entre os povos". Como tal, SHEIK MANI defende que esse tratado vincula a todos os Estados, haja vista o direito internacional consuetudinário. $^{18}$

A instituição consular surge com o aumento da troca de relações entre os povos, com fundamento na idéia ancestral de que o estrangeiro merece especial atenção no território de acolhimento, que lhe deve dispensar melhor hospitalidade, protegendo-o. ${ }^{19}$ Com efeito, A história da função consular é amplamente associada

\footnotetext{
${ }^{16}$ LeE, Luke T. J.D. and Quigley, John. Consular Law and Practice, p. 03.

17 AgO, Roberto. The First International Communities in the Mediterranean Wold, apud. LEE, Luke T. J.D. and QuigleY, John. Consular Law and Practice, p. 04.

${ }^{18}$ SHEIK, MANI. From Breard to Medellin: Supreme Court Inaction or ICJ Activism in the Field of International Law?, p. 535.

${ }^{19}$ WLADIMIR BRITO lembra que já no Antigo Testamento a idéia de bondade e hospitalidade devidas ao estrangeiro aparece em vários momentos, por exemplo, no livro do Êxodo, 22, 21, que diz que "não molestarás, nem afligirás estrangeiro, porque também vós fostes estrangeiro na terra do Egito", ou no Livro do Levítico, 19, 33 e 34, se diz: "Se algum estrangeiro habitar na vossa terra, e morar entre vós, não o impropereis; mas esteja entre vós como um natural; amai-o como a vós mesmo, porque também vós fostes estrangeiros na terra do Egito". No Livro do Deuteronômio, 23, 7: "Não abominarás o idomeu, porque é teu irmão, o egípcio, porque fostes forasteiro na sua terra”; ou quando diz "Maldito seja o que perverte a justiça do estrangeiro, do órfão e da viúva". Na antiga Índia, de acordo com as leis do Código Manú, ao hóspede estrangeiro deveria ser dispensado tratamento caritativo e de boa hospitalidade, até que, entre os seis grupos de administradores das comunas, o segundo grupo ocupava-se da hospitalidade dos estrangeiros, devendo proporcionar-lhes alojamento, alimento, inspecionar a sua conduta, enterrá-los e assegurar o transporte dos seus bens, cuidar deles quando enfermos. Os Hebreus, como resulta do Antigo Testamento, marcados pela
} 
ao desenvolvimento do comércio internacional e os interesses econômicos dos Estados. Todavia, embora as origens da instituição consular remontem à Grécia antiga, não foi até o século XII que a primeira figura do cônsul surgiu e desenvolveu a sua estrutura atual e mais complexa. Além disso, os primeiros códigos de funções consulares foram desenvolvidos ao longo do mesmo período, principalmente na forma de compilações de direito marítimo. A crescente necessidade de proteger o comércio e a navegação dos atos de pirataria e de pilhagem levou a que, por exemplo, na Grécia, fossem criados no seio das comunidades estrangeiras nelas sediadas, assim como nas comunidades gregas formadas em território estrangeiro, mecanismos jurídico e políticos de proteção aos comerciantes navegadores. Mas a instituição consular, no sentido moderno do termo aparece com as Cruzadas, embora na Antiguidade, figuras exerciam funções em tudo idênticas àquelas que a partir do Século XI foram assumidas pelos cônsules - um tratamento especial concedido aos estrangeiros, com uma quase obrigação de lhes garantir boa hospitalidade estabelecida pelos costumes locais, ou até mesmo por normas escritas de vários povos da Antiguidade. ${ }^{20}$

Então, entre tantas contribuições políticas das cidades-Estados gregas está o desenvolvimento primitivo do sistema consular. Os prostates e os proxenos são considerados os precursores do cônsul moderno. Os prostates eram escolhidos pelos colonizadores gregos que moravam além do território grego para atuarem como intermediários em suas relações jurídicas e políticas junto aos governos locais. Ao redor do século VI a.C., os egípcios permitiram que os colonos gregos que viviam em Náucratis selecionassem um prostates para administrar o direito grego aos gregos, em especial no comércio. ${ }^{21}$

opressão que sofreram nas terras egípcias, dispensavam proteção e especial tratamento aos estrangeiros, e criaram um Tribunal especial, denominado Noachides, para julgá-los. CORREIA DE BRITO, Wladimir Augusto. Direito Consular, pp. 15 e 16.

${ }^{20}$ Correia De Brito, Wladimir Augusto. Direito Consular, pp. 14-15. É possível periodizar a evolução da instituição consualr em quatro períodos: $1^{\circ}$ ) entre os séculos XIII ao XVI, é o período do Cônsul-juiz; $2^{\circ}$ ) do século XVI ao XVII, é o período do Cônsul representante do Estado; $3^{\circ}$ ) do final do século XVII até o XIX, é o período do Cônsul defensor do comércio e da navegação; $4^{\circ}$ ) do final do século XIX até o século XX.

${ }^{21}$ Nesse mesmo período, instituições semelhantes podiam ser identificadas na Índia. LEE, Luke T. J.D. and Quigley, John. Consular Law and Practice, p. 04. WladiMIR BRITO explica que o Rei egípcio AMNÉS II permitiu aos Gregos estabelecer na margem esquerda do canal de Canopique, desembocadura do Nilo, um colônia em Náucratis e no ano 526 a.C. elegeram entre eles o prostates. CORREIA DE BRITO, Wladimir Augusto. Direito Consular, p. 15. 
Durante o primeiro milênio a.C, os proxenoi eram indicados por "estados" estrangeiros para representar seus interesses nas cidades-Estados gregas. O proxenos era escolhido entre os nacionais do "estado receptor", daí sua equivalência com o moderno Cônsul Honorário. ${ }^{22} \mathrm{O}$ proxenos desenvolvia diversos serviços aos nacionais do estado que enviava: proteção; segurança para empréstimos; promovia a venda de suas cargas; providenciava o testamento se morriam no estrangeiro sem têlo feito. Ele recebia oficiais diplomáticos do "estado que enviava" e os auxiliavam em suas funções, e relações pessoais. Também era chamado para estar presente nas negociações de tratados e nas disputas arbitrais entre o "estado que enviava e o que recebia". Ocasionalmente, podia ser enviado como embaixador ao estado que previamente representara. A indicação como proxenos passou a ser muito visada, passando a ser recompensada com honras e privilégios. Estima-se que, pelo menos, setenta e oito cidades-estados gregas, cidades e confederações, adotavam a instituição do proxenos. ${ }^{23}$

Em 242 a.C., a República Romana criou a instituição do praetor peregrinus para solucionar as disputas judiciais entre estrangeiros (peregrini), ou entre estrangeiros e cidadãos romanos. Os casos eram julgados pelo jus gentium, que incluía tanto o direito estrangeiro quanto as práticas costumeiras comerciais. O termo “cônsul” referia-se a figura de um governande sem a conotação diplomática,

${ }^{22} \mathrm{O}$ artigo $1^{\circ}, 2$, da CVRC dispõe que: "Existem duas categorias de funcionários consulares: os funcionários consulares de carreira e os funcionários consulares honorários. As disposiçães do Capítulo II da presente Convenção aplicam-se às repartições consulares dirigidas por funcionários consulares de carreira; as disposições do Capitulo III aplicam-se às repartições consulares dirigidas por funcionários consulares honorários." O termo "Cônsul Honorário" não é usado no mesmo sentido no direito de todos os países. Em alguns, o critério determinante é o fato de que o funcionário em causa não é pago pelo seu trabalho consular. Outras leis reconhecem explicitamente que os cônsules de carreira podem ser remunerados ou não, e na base da distinção entre a carreira e os cônsules honorários é o fato de que os primeiros são enviados ao exterior e os últimos recrutados localmente. Sob os termos de alguns regulamentos consulares, o termo "cônsul honorário", diz respeito a um agente que não é nacional do Estado que envia e que, além de suas funções oficiais, está autorizado a exercer uma atividade remunerada no Estado receptor, se ele de fato exercer a ocupação ou não. Para efeitos de concessão de imunidades consulares, alguns Estados-Membros consideram os representantes dos cônsules honorários, independentemente da sua nacionalidade, que, além de suas funções oficiais, exercem uma atividade profissional no Estado receptor. Finalmente, em muitos Estados, como os cônsules honorários são todos os cônsules que não são os de carreira. International LaW COMmission. TeXts, Instruments and Final Reports. Consular InTERCourse AND IMmunities. Draft Articles on Consular Relations with Commentaries, 1961. Disponível online em: <http://untreaty.un.org/ilc/texts/instruments/english/commentaries/9_2_1961.pdf> $\quad$ (acesso em 26/03/2010).

${ }^{23}$ LeE, Luke T. J.D. and Quigley, John. Consular Law and Practice, p. 04. 
nomeados pelo Imperador. Durante o século XII d.C. o título de cônsul era concedido a magistrados especiais com jurisdição sobre colônias comerciais estrangeiras semi-autônomas estabelecidas no Império Bizantino após a queda do Império Romano em 476 d.C. No ano de 1060, Veneza adquiriu o direito de enviar magistrados para Constantinopla para julgar venezianos envolvidos em casos civis e criminais. Os poderes dos magistrados foram estendidos pelo Imperador Alexius III's Golden Bull em 1119 para cobrir disputas entre venezianos e sujeitos do Império Bizantino. Logo, Gênova (1204); Montpellier (1243) e Narbonne (1340) também adquiriam o direito de estabelecer colônias no Império, e indicar seus próprios magistrados em Constantinopla. ${ }^{24}$

O crescimento do comércio, durante e depois do período das Cruzadas, estimulou o desenvolvimento do sistema consular. Mercadores italianos, espanhóis e franceses escolhiam entre si cônsules que atuariam no Ocidente para lá supervisionar seus comércios, proteger seus interesses, e adjudicar disputas entre mercadores. Assim, Marselha obteve autorização para enviar cônsules a, por exemplo, Beirute (1223); Montpellier, em Trípoli e Chipre (1254), e em Rhodes (1356); e Narbona, em Rhodes (1351). ${ }^{25}$ Mas foi com os tratados das Capitulações entre países cristãos e muçulmanos que o poder dos cônsules se fortaleceu. Por exemplo, Gênova (1453), Veneza (1454) e a França (1535) concluíram Capitulações com Bizâncio. Sob esses tratados, aos cônsules era concedido jurisdição civil e criminal sobre seus nacionais que residiam no Império Bizantino. ${ }^{26}$

A indicação de cônsules por nacionais residindo no exterior tornou-se uma prática freqüente no Oriente. No final da Idade Média, os mercadores estrangeiros nas cidades comerciais da Itália, Espanha e França elegiam companheiros, conhecidos como "juges consuls" ou "consul marchands" como árbitros de disputas comerciais. Em 1279, o "Consolato del Mare" - uma coleção de Ordenanças e costumes que influenciaram o surgimento do direito marítimo europeu - reconhecia magistrados que acompanhavam navios em suas viagens como cônsules. No século XV havia cônsules italianos residindo na Inglaterra e na

\footnotetext{
${ }^{24}$ LeE, Luke T. J.D. and Quigley, John. Consular Law and Practice, pp. 04 e 05.

${ }^{25}$ LeE, Luke T. J.D. and Quigley, John. Consular Law and Practice, p. 05.

${ }^{26}$ LeE, Luke T. J.D. and Quigley, John. Consular Law and Practice, p. 05.
} 
Holanda; enquanto cônsules ingleses podiam ser encontrados na Holanda, Noruega, Suécia, Dinamarca e Itália (Pisa). Eles exerciam jurisdição exclusiva, civil e criminal, sobre comerciantes da sua própria nacionalidade. ${ }^{27}$

Não foi até o século XI que as autoridades do Estado cada vez mais centralizado passaram a garantir controle direto sobre os estabelecimentos consulares. O Estado passou a despachar cônsules, que assumiram caráter de ministros públicos, passaram a desempenhar algumas funções diplomáticas, e gozavam de algumas imunidades e privilégios. Isso resultou em uma confusão entre as funções do cônsul e do diplomata - confusão que não foi esclarecida até o século XX. O incremento da manutenção pelos Estados de missões diplomáticas permanentes no exterior, seguida do emergente sentimento nacionalista contra a extraterritorialidade, causou um verdadeir "eclipse" das instituições consulares no século XVIII. Alguns Estados viam as instituições consulares com descrédito. ${ }^{28}$

No entanto, em virtude do enorme desenvolvimento econômico na Europa, do progresso nos sistemas de navegação e de comunicação, do crescente aumento das trocas comerciais, as relações consulares intensificavam-se, o que acelerou a produção interna quanto à legislação consular. ${ }^{29}$

O final do século XVIII testemunhou o desenvolvimento do comércio, navegações, indústria, tanto que mais uma vez as atenções dos governos se voltaram

\footnotetext{
${ }^{27}$ No outro lado do planeta, no Império Celestial da China, Oficiais Consulares - em função, se não em nome - operavam lá centenas de anos antes da abertura oficial ao Ocidente na metade do século XIX. Mas o destaque é quando o Cônsul americano em Tietsin firmou, no início de 1949, comunicações endereçadas às autoridades da não-reconhecida China Comunista, com o título "à comunidade americana de Tietsin". LEE, Luke T. J.D. and QuigleY, John. Consular Law and Practice, pp. 05-06.

${ }^{28}$ Nesse sentido, LEE menciona como exemplo o artigo 30 do tratado de Ryswick, firmado entre Países Baixos e França em 1697; assim como o artigo 38 do tratado de Uchtrecht de 1713; e o artigo 40 do tratado de Versalhes de 1739, que dispõe: "A l'avenir aucuns consuls ne seront admis de parte et d'autre; et si l'on jugeait à propos d'envoyer dês residents, agents, commissaires ou autres, ils NE pourront établir leur demeure que dans lês lieux de residence ordinaire de la Cour."

${ }_{29}$ Por exemplo, nos Estados Unidos da América do Norte, em 1792, com a sua primeira legislação consular; nos Países Baixos em 1838; no Reino Unido em 1846; na Confederação Germânica em 1867. A partir do século XX, praticamente todos os países se dotam de legislação consular. É esse movimento que incrementa a celebração de acordos bilaterais sobre o tema, o que contribui para o desenvolvimento e aperfeiçoamento do direito consular internacional, abrindo-se o caminho para se pensar em uma codificação internacional. CORREIA DE BRITO, Wladimir Augusto. Direito Consular, p. 36 .
} 
ao sistema consular. Referências específicas às funções, privilégios e imunidades dos cônsules foram feitas em alguns tratados comerciais e consulares, cujo primeiro foi a CONVENÇÃo Franco-EsPanhola DE PARDO, de 13 de março de $1769 .{ }^{30}$ Durante o século XIX o Oriente abriu-se não apenas ao comércio ocidental, mas para concessão de privilégios extraterritoriais para os nacionais do Ocidente. Em vista da incompatibilidade básica entre extraterritorialidade e o sistema moderno de Estadonação (com ênfase na igualdade entre as soberanias e na jurisdição territorial), as concessões extraterritoriais não podiam ser consideradas mais do que uma fase passageira. No entanto, muitos dos fatores extraterritoriais sobreviveram nas instituições consulares até hoje, embora em formas diferentes.

O crescimento das repartições consulares aconteceu durante os séculos XIX e XX revelando a necessidade de um quadro jurídico mais preciso, sobretudo relativamente ao serviço consular e ao estatuto jurídico dos cônsules. ${ }^{31}$ Posteriormente, as mudanças na atividade social, política e econômica, passaram a afetar a vida diária, criando um novo desafio para a instituição consular: a proteção dos cidadãos e da salvaguarda dos seus interesses.

Algumas tentativas preliminares com vistas à codificação oficial do Direito Internacional Consular resultaram na aprovação de acordos regionais, antecedendo o trabalho pioneiro realizado pela Liga das Nações sobre o assunto. ${ }^{32}$

\footnotetext{
${ }^{30}$ Nações líderes do comércio e navegações também começaram a promulgar estatutos para definir as funções de seus cônsules no exterior. Por exemplo: Ordenanças Francesas (1781 e 1833); Regulações Consulares dos Países Baixos (1786); Lei de Serviços Consulares dos EUA (1792 e 1856); Lei Britânica de Avanços Consulares (1825). o Tratado de Comércio Franco-Britânico (1860) - o Tratado Cobden - marcou a inauguração de uma nora era comercial, com convenções baseadas em princípios do livre-comércio e na cláusula da nação mais favorecida, além de uma série de tratados consulares semelhantes celebrados a partir de 1860, o envio e recepção de cônsules passaram a se ater em um alto grau de uniformidade de leis e práticas.LEE, Luke T. J.D. and QUIGLEY, John. Consular Law and Practice, pp. 06 e 07.

${ }^{31}$ A partir do final do século XVII a necessidade de dotar a função consular de uma regulamentação jurídica da sua organização e da jurisdição dos cônsules começa a impor-se em diversos Estados. Na França, Colbert, em 1681, publica pela primeira vez um regulamento sobre a organização e jurisdição consular - Ordennance de la Marine - com 27 artigos, que servirá de modelo à abundante legislação francesa sobre a função consular que se desenvolve a partir de 1778 com o "Edit Du Roi portant règlement sur lês fonctions judiciaires et de policie qu'exercent lês consuls de France em pays étranger". CORREIA DE BRITO, Wladimir Augusto. Direito Consular, p. 36.

32 Merecem destaque três grandes iniciativas institucionais, pelo impacto que tiveram no meio jurídico-internacional e contribuição no processo codificador. Primeiro, a iniciativa do INSTITUTO DE DIREITO INTERNACIONAL, em 1888, na sessão de Lousanne, a primeira iniciativa institucional de fundo para a codificação do Direito Consular Internacional, com ENGENHARDT como encarregado de
} 
Apesar das conclusões da Liga das Nações a respeito da importância do regulamento consular, por meio de instrumentos internacionais, a questão ficou pendente por quase vinte anos. Em 1928 foi aprovado o texto da CONVENÇÃo SOBRE AGENTES CONSUlares $^{33}$, na cidade de Havana. Como as relações consulares, eram, no passado, principalmente reguladas por acordos bilaterais e leis nacionais, havia uma grande variedade de práticas. A tarefa da Conferência de 1963 seria chegar a uma medida tão ampla quanto possível de um acordo sobre os princípios básicos do assunto, em base global. ${ }^{34}$

Foi apenas na primeira metade do século XX que se tornou possível codificar o direito internacional consular, pela primeira vez com uma Convenção de caráter regional, a Convenção sobre Relações Consulares de 1928, aprovada na Sexta Conferência Internacional Americana, ${ }^{35}$ e, mais adiante, a Convenção de natureza

apresentar um relatório sobre a imunidade consular, o que veio a fazer nas sessões seguintes, em 1891, Hamburgo, e em 1892, em Gênova, quando apresentou um projeto de resolução e um Projeto de Regulamento com 22 artigos. Esse trabalho foi bastante importante, porque prescrevia com bastante precisão as condições e limites da imunidade dos cônsules. A segunda iniciativa é a do Instituto AMERICANO DO DIREITO INTERNACIONAL, que adotou, em 1925, um projeo de Convenção. A terceira iniciativa veio da HARVARD SCHOOL OF LAW, na preparação de um Projeto de artigos elaborado a partir de um relatório do Professor QUINCY WRIGHT - Draft Convention of Harvard Law School of 1932 on the Legal Position and Function of Consuls - com 32 artigos, dividido em seis seções, com importantes informações sobre as relações consulares. Para Wladimir Brito, "todas essas iniciativas tiveram forte impacto no meio acadêmico e foram importantes não só para o estudo do Direito Consular Internacional, como para estimular a prática convencional multilateral no domínio das relações consulares".CORREIA DE BRITO, Wladimir Augusto. Direito Consular, p. 40.

${ }^{33}$ A Convenção sobre os Estrangeiros (1928), Decreto n. 18.956 - de 22 de outubro de 1929 promulga seis convenções de Direito Internacional Público, aprovadas pela Sexta Conferência Internacional Americana. Tendo sido sancionado pelo Presidente da República dos Estados Unidos do Brasil, por meio do decreto n. 5.647, de 8 de Janeiro de 1929, a resolução do Congresso Nacional approvou as seguintes convenções de direito internacional publico, adotadas pela Sexta Conferencia Internacional Americana, reunida em Havana, e assignadas a 20 de Fevereiro de 1928: 1) Convenção sobre condição dos estrangeiros; 2) Convenção sobre tratados; 3) Convenção sobre funccionarios diplomaticos; 4) Convenção sobre agentes consulares; 5) Convenção sobre Asilo; 6) Convenção sobre deveres e direitos dos Estados, nos casos de luctas civis; - e havendo-se efetuado o depósito do instrumento brasileiro de ratificação das ditas convenções, na Secretaria da União Panamericana, em Washington, a 29 de Agosto do mesmo ano.

34 United NATIONS CONFERENCE ON CONSUlar RElATIONS VienNA A/CONF.25/16. Official Records. Volume I: Summary records of plenary meetings and of the meetings of the First and Second Committees, p. 01. Vienna, March $4^{\text {th }}-$ April $22^{\text {nd }}, 1963$. Disponível online em: <http://untreaty.un.org/cod/diplomaticconferences/consrelat-1963/vol/english/vol_I_e.pdf> (acesso em 28/03/2010).

35 Projeto de Codificação do Direito Consular Internacional promovido por Organizações Internacionais Governamentais: Organização das Nações Unidas e Conselho da Europa: O primeiro projeto foi elaborado pela Comissão Inter-Americana de Juristas, reunida no Rio de Janeiro em 1927 (Sexta Sessão), para realizar a "codification of public and private international Law as a means of consolidating and developing the good relation which should exist between them". Nesse quadro, a Comissão elaborou doze projetos de Direito Internaiconal Público, detre os quais, o Direito Consular - o projeto "Consuls" - n. ${ }^{\circ}$ VIII, com 26 artigos, serviu de base para a elaboração da CONVENÇÃO DE 
universal, a Convenção de Viena sobre Relações Consulares de $1963 .{ }^{36}$ Até a sua entrada em vigor, em 19 de março de 1967, ou seja, no trigésimo dia após a data em que fora depositada junto ao Secretário-Geral da Organização das Nações Unidas o vigésimo segundo instrumento de ratificação ou adesão ${ }^{37}$, as relações consulares eram governadas por um pequeno número de regras costumeiras de Direito Internacional. Normas adicionais foram providenciadas por tratados bilaterais por vezes conflitantes, e por alguns tratados regionais. ${ }^{38}$ Vários projetos de codificação foram dedicados à posição jurídica e às funções dos cônsules, mas o direito consular não recebeu a devida atenção dos internacionalistas. ${ }^{39}$

O esforço para concluir um tratado multilateral sobre relações consulares foi parte do esforço da recém formada Organização das Nações Unidas para promover o desenvolvimento e codificação do direito internacional. ${ }^{40}$ Em 1949 ,

Havana sobre os AgEntes CONSUlares, que veio a ser adotada na Sexta Convenção PanAmericana, realizada em Havana, em janeiro de 1928. Essa conveção foi assinada por todos os delegados à Conferência, e mais tarde ratificada pelo Brasil, Colômbia, República Dominicana, México, Nicarágua, Panamá, e Estados Unidos da América do Norte. Embora de caráter regional, revelou ser possível a regulamentação das relações consulares, influenciando decisivamente a feitura de uma convenção multilateral das relações consulares, agora de caráter universal. CORREIA DE BRITO, Wladimir Augusto. Direito Consular, pp. 46-47.

36 Antes da primeira convenção regional, tentativas individuais ou institucionais foram feitas no sentido de uma codificação do direito internacional consular, mas a sociedade internaiconal ainda não estava me condições de aceitar uma Convenção multilateral, mesmo que de natureza regional, preferindo manter a regulamentação jurídica da instituição pela via de acordos consulares bilaterais ou pela via do costume internacional. CORREIA DE BRITO, Wladimir Augusto. Direito Consular, p. 35.

37 Artigo 77 da CVRC. "Entrada em Vigor. 1. A presente Convenção entrará em vigor no trigésimo dia que se seguir à data em que seja depositado junto ao Secretário-Geral as Organização das Nações Unidas o vigésimo segundo instrumento de ratificação ou adesão. 2. Para cada um dos Estados que ratificarem a Convenção ou a ela aderirem depois do depósito do vigésimo segundo instrumento de ratificação ou adesão, a Convenção entrará em vigor no trigésimo dia após o depósito, por esse Estado, do instrumento de ratificação ou adesão."

${ }^{38} \mathrm{O}$ especialista em direito consular, Luke T. Lee, providencia um apêndice com uma lista exaustiva de tratados bilaterais sobre relações consulares firmados desde 1923 até 2004. LEE, Luke T. J.D. and Quigley, John. Consular Law and Practice, pp. 590 - 601.

${ }^{39}$ Lee menciona autores como: Bluntschli, em 1868; Field, em 1876 e Fiore, em 1898; e o Projeto de Pesquisa de Harvard, em 1932, que não foi atualizado até 1961, e depois em 1991. LEE, Luke T. J.D. and Quigley, John. Consular Law and Practice, pp. 16 e 17.

${ }^{40}$ Artigo 13 da Carta da ONU: "1. A Assembléia Geral iniciará estudos e fará recomendações, destinados a: a) promover cooperação internacional no terreno político $e$ incentivar o desenvolvimento progressivo do direito internacional e a sua codificação; (...)". Em 1949 o então Secretário-Geral TRYGVE LIE enfatizou que "tendo em vista a contínua expansão do comércio internacional, a posição jurídica e funções dos cônsules deveria ser regularizada numa base universal. LeE, Luke T. J.D. and Quigley, John. Consular Law and Practice, p. 21. Desde a década de 30 do século XX, a Assembléia Geral da Sociedade das Nações (SdN) nomeou um Comitê de Peritos para a codificação progressiva do Direito Internacionalque elaborou uma lista com sete questões cuja codificação seria desejável, snedo revisada mais tarde, acrescentando-se a questão da situação jurídica dos cônsules. Foi nomeado um sub-comitê para elaborar um relatório sobre essa questão. O subcomitê afirmou no relatório que a codificação internacional sobre a situação jurídica dos cônsules era 
de 12 de abril a 09 de junho, na sua primeira sessão, a COMISSÃo DE DIREITO INTERNACIONAL DAS NAÇÕES UNIDAS considerou a inclusão das relações consulares e imunidades como parte de seus futuros trabalhos de codificação, sem colocar, no entanto, o assunto na lista de prioridades, mas entre outros treze pontos. Na sua sétima sessão, realizada em Genebra, entre 02 de maio e 08 de julho de 1955, a Comissão nomeou JAROSLAV ZOUREK como Relator Especial para iniciar a revisão do assunto e elaborar um conjunto de normas provisórias. Todavia, a discussão não começou formalmente até 1958. O Projeto de conjunto de regras que mais tarde foram divididas em quatro capítulos (relações consulares e imunidades; privilégios consulares e imunidades; estatuto jurídico dos cônsules honorários e seus privilégios e imunidades, e disposições gerais), acompanhado de comentários, foi submetido aos Estados-Membros da ONU para suas observações em diferentes estágios de negociação. Em 1960, a Comissão adotou uma primeira versão, junto com comentários, e transmitiu aos Governos para os seus comentários. Em 1961, a Comissão adoptou um projecto final sobre as relações consulares, e recomendou à Assembléia Geral da ONU que convocasse uma conferência internacional de plenipotenciários para concluir uma Convenção.

\section{A CONFERÊNCIA SOBRE RELAÇÕES E IMUNIDADES DIPLOMÁtiCAS,} ocorrida entre os dias 02 de março a 14 de abril de 1961, com a presença de delegações de oitenta e um países, dos quais setenta e cinco eram membros da Organização das Nações Unidas, e seis agências relacionadas ou partes no Estatuto da Corte Internacional de Justiça ${ }^{41}$, beneficiou-se do Congresso de Viena de 1815 ,

indispensável para evitar conflitos que a falta de regras precisas sobre a matéria acabaria sempre por causar. Daí, foram criadas condições jurídico-políticas internacionais para a elaboração de uma convenção multilateral de caráter universal sobre relações consulares, tarefa que será retomada pela ONU, cuja Assembléia convoca uma conferência internacional com vistas à codificação internacional das relações consulares, que ocorre finalmente em 1963. O último grande projeto foi o do Conselho da Europa, levado a cabo em 1967, a partir da idéia de elaborar uma convenção européia sobre relações consulares, surgida em 1961. Resolveu-se limitar a questão às funções consulares, dado que a CVRC não regulava essa matéria com profundidade. O projeto foi aprovado pelo Comitê de Ministros do Conselho, e aberto a assinaturas dos Estados Membros, com 6 capítulos e 57 artigos, e 2 anexos, e cujo Preâmbulo ressalta que complementa a CVRC, e que as matérias que não fossem nela reguladas seriam reguladas pelo direito internacional costumeiro. CORREIA DE BRITO, Wladimir Augusto. Direito Consular, pp. 41-43.

${ }^{41}$ Em sua décima segunda sessão, realizada entre 25 de abril e 01 de julho de 1960, a Comissão adotou um projeto com 65 artigos determinou que os artigos referentes aos cônsules de carreira deveriam ser igualmente aplicáveis aos cônsules honorários. Consequentemente, incluiu normas mais abrangentes e inseriu alguns artigos novos, antes de adotar provisoriamente o projeto de artigos e seus comentários. A semelhança do tema com as questões de imunidade diplomática levou à adoção de um 
quando foi aprovado o primeiro instrumento internacional para codificar qualquer aspecto do direito diplomático, o Regulamento que simplificou as regras complexas sobre as classes de chefes de missões diplomáticas e estipulou que prevalece entre os chefes de missões a data de chegada ao posto. O Brasil participou da Conferência, representado pela delegação cujos membros foram Joaquim de Souza Leao Filho Presidente da Delegação, na ocasião o Embaixador do Brasil na Haia; Roberto de Arruda Botelho, Embaixador do Brasil em Viena, Geraldo Eulalio do Nascimento e Silva, como Conselheiro, e Egberto da Silva Mafra, ambos Primeiros Secretários de Embaixada.

A CONFERÊNCIA SOBRE RELAÇÕES CONSULARES DE 1963 foi o mesmo que "desbravar novos caminhos". ${ }^{42}$ Pela primeira vez, aconteceu um esforço no

procedimento acelerado. Na décima terceira Sessão, a Comissão de Direito Internacional adotou o Projeto Final sobre Relações Consulares com comentários, de 71 artigos, e submeteu à Assembléia Geral das Nações Unidas, com vistas à adoção de uma convenção sobre o assunto. $\mathrm{O}$ órgão recomendou então que a Assembléia Geral das Nações Unidas convocasse uma conferência internacional de Plenipotenciários, o que foi aprovado por meio da resolução 1685 (XVI) de 18 de dezembro de 1961. Na sua décima sétima sessão, em 1962, a Assembléia discutiu novamente a questão e adotou a resolução 1813 (XVII) de 18 de dezembro de 1962, em que requereu que os registros e documentos da sessão fossem transmitidos à Conferência, e convidou os Estados a submeterem até 10 de fevereiro de 1963 quaisquer emendas, para atingir seus objetivos efetivamente, na preparação de uma convenção que, aberta às variações da prática, definiria claramente os princípios básicos das relações consulares, e que fosse amplamente aceitável aos Estados. A Conferência, assim, atingiu os seus objetivos, e um importante passo seria dado em direção à codificação e desenvolvimento progressivo do direito internacional.

Para saber mais a respeito da Conferência dobre Relações e Imunidades Diplomáticas, informações estão disponíveis na página principal, disponível online em: <http://untreaty.un.org/cod/avl/ha/vcdr/vcdr.html>, (acesso em 22/03/2011).

${ }^{42}$ No dia 18 de setembro de 1814, representantes de quase todas as nações européias participaram da grande Conferência de Paz de Viena. Seu objetivo foi a reordenação política da Europa após as guerras napoleônicas. O Congresso de Viena de 1815 inaugura uma nova fase diplomática. As monarquias européias sentiam estar às vésperas de uma mudança radical na sua diplomacia tradicional, isso em face do impacto da Revolução Francesa e das guerras napoleônicas. O surgimento de uma potência não européia, como os Estados Unidos, contribuiu para isso. O REGULAMENTO SOBRE A CLASSIFICAÇÃO DIPLOMÁTICA, em que pela primeira vez se codificaram regras referentes às relações diplomáticas, teve o mérito de acabar definitivamente com as disputas de precedência que, até então, representavam uma das maiores preocupações do agente diplomático, eis que uma ofensa protocolar à sua pessoa era o mesmo que ofender a pessoa de seu soberano. Também adotou o sistema do alternat por ocasião da assinatura de tratados. As Embaixadas no exterior passaram a ser mais modestas e cuidadosamente selecionadas, devido às enormes despesas. O Regulamento de Viena de 19 de março de 1815, que regulamentou a precedência dos agentes diplomáticos e suas consequiências, foi acolhido pelo Congresso de Viena de forma desesperada. Uma comissão apresentou projeto dividindo os agentes diplomáticos em três classes, o que não vingou. Daí o projeto limitou-se na precedência, recorrendo à uma fórmula apresentada em 1790 pelo Marques de Pombal, quando do matrimônio de Dom Pedro com a princesa do Brasil, que determinou que, no futuro, os embaixadores seriam recebidos de conformidade com a antiguidade das credenciais, sendo adotado, apesar das críticas na época, o seguinte artigo $4^{\circ}$ : "Os empregados diplomáticos terão precedência entre si, em cada classe, segundo a data da notificação oficial de sua chegada". O parágrafo único acrescenta: "o 
sentido de preparar um código sobre as relações consulares, com a colaboração de membros de todas as partes do mundo.

\section{A CONFERÊNCIA DAS NAÇÕES Unidas SOBRE RELAÇÕES}

CONSUlARES $^{43}$ foi realizada em Viena, Áustria, entre 04 de março a 22 de abril de 1963, e contou com a participação de delegados de noventa e dois Estados (inclusive o Brasil $)^{44}$, onze a mais que o número de Estados participantes da CONFERÊNCIA SOBRE RELAÇÕES E IMUNIDAdES DiPlomáticAS. Ademais, três Estados e quatro

presente regulamento não altera a situação dos representantes do Papa”. Daí, a maioria dos Estados, inclusive o Brasil, passaram a determinar a antiguidade pela data da apresentação das credenciais. A extinção do Sacro Império Romano e o enfraquecimento da França, que intransigente em questões de precedência, baseando-se na antiguidade da monarquia, facilitaram a adoção do Regulamento. Embora a Ata Final do Congresso de Viena, da qual o Regulamento sobre precedência figure como o anexo 17, tenha sido firmado por um número restrito de Estados, foi aceito expressa e tacitamente pelos Estados que surgiram posteriormente para a vida internacional. Em 21 de novembro de 1818 foi firmado protocolo estabelecendo que os ministros residentes formariam, em matéria de precedência, uma classe intermediária entre os ministros de segunda ordem e os encarregados de negócio. Nascimento e Silva, G. E. de. Diplomacia e Protocolo, pp. 101-104.

43 A Conferência das Nações Unidas sobre Relações Consulares, que contou com a participação de delegados de noventa e cinco Estados, inclusive o Brasil, reuniu-se em Viena, entre 04 de março a 22 de abril 1963. A Conferência considerou os artigos do Projeto elaborado pela Comissão de Direito Internacional, e algumas propostas adicionais, a dois comitês principais, cada um composto por todos os Estados participantes. Depois de terem os artigos e as propostas sido tratadas nas comissões principais, foram encaminhadas a uma comissão de redação, que preparou textos de apresentação para a reunião, realizada em sessão plenária. A Conferência aprovou a Convenção de Viena sobre Relações Consulares, constituída por setenta e nove artigos, um Protocolo Facultativo relativo à aquisição de nacionalidade e um Protocolo Facultativo relativo à Solução Compulsória de Controvérsias. Viena, que foi a casa da renomada Konsular-Akademie (Academia Consular), fundada em 1754 pela imperatriz Maria Teresa para a formação dos cônsules, e foi, durante séculos um dos grandes centros para o estudo do direito internacional, era um local particularmente apropriado para uma conferência sobre o direito consular. Numa altura em que as relações internacionais tinham assumido uma importância crescente para a vida de toda a humanidade, tornou-se cada vez mais desejável para colocá-las em uma base segura de clara, geralmente reconhecidas e geralmente observadas as regras de direito. Cônsules, como agentes diplomáticos, desempenham um papel importante nas relações internacionais. O desenvolvimento geral das viagens ao estrangeiro, comércio internacional e transporte aumentou o volume de atividades consulares em todo o mundo, e para essas atividades equipes consular maiores tornaram-se necessárias. Esclarecer o direito consular, assim, contribuiria para a promoção de relações amistosas entre os Estados. UNITED NATIONS CONFERENCE ON CONSUlar RElations VIENNA A/CONF.25/16. Official Records. Volume I: Summary records of plenary meetings and of the meetings of the First and Second Committees, p. 01. Vienna, March $4^{\text {th }} \quad-$ April $22^{\text {nd }}, \quad 1963 . \quad$ Disponível online <http://untreaty.un.org/cod/diplomaticconferences/consrelat-1963/vol/english/vol_I_e.pdf> (acesso em 28/03/2010).

${ }^{44}$ Participaram como representantes da Delegação brasileira: H.E. Mr. Mario Gibson Alves Barboza (Embaixador para a Áustria, e presidente da Delegação); Geraldo E. Nascimento e Silva, MinistroConselheiro em Londres; Carlos F. Duarte Gonzalves da Rocha, Ministro-Conselheiro em Viena. Conselheiros: Ruy B. Miranda e Silva, Chefe da Divisão Consular, Ministro das Relações Exteriores; Marcos Henrique Menezes Cortes, Segundo Secretário da Embaixada em Viena. M. Gibson Alves Barbosa atuou na Segunda Comissão. O Brasil atuou na Comissão de Redação, juntamente com Argentina; China; Espanha; Estados Unidos; França, Gana; Hungria; Índia; Reino Unido da GrãBretanha e Irlanda do Norte; Suíça; União das Repúblicas Socialistas Soviéticas. 
agências especializadas e organizações internacionais interessadas enviaram observadores. $^{45}$ Após um exame atento do texto da Comissão de Direito Internacional, a versão final foi preparada para apresentação ao plenário. Em 24 de abril de 1963, a Conferência aprovou e foram abertos à assinatura a Convenção de Viena sobre Relações Consulares, o Protocolo Facultativo relativo à aquisição da nacionalidade e o Protocolo Facultativo relativo à solução compulsória de controvérsias. A Convenção e os dois Protocolos Facultativos entraram em vigor em 19 de março de $1967{ }^{46}$

Durante a Conferência, quanto às negociações sobre o artigo 36 do Projeto de Convenção, as discussões sobre o acesso consular "sem tardar" foram tortuosas, tanto que ameaçaram por fim na Convenção de Viena Sobre Relações Consulares de 1963 em si. É justamente o artigo 36 o dispositivo que orienta o presente trabalho. Seu parágrafo 1(a) do dispositivo estabelece a liberdade de comunicação entre os funcionários consulares com os nacionais do Estado que envia. O parágrafo 1(b) pontua os direitos disponíveis ao estrangeiro presos no exterior, que pode pedir que sua detenção seja informada à Repartição Consular de seu país. Enfatiza a importância de o indivíduo privado de liberdade de ser informado pelas autoridades competentes, sobre esses direitos, "sem tardar". Da mesma forma o Consulado deve receber essa informação "sem tardar”. O parágrafo 1(c) dispõe sobre a liberdade dos Funcionários Consulares para visitarem seus nacionais privados de liberdade, providenciar sua defesa perante os tribunais e, da mesma forma, em

\footnotetext{
${ }^{45}$ Bolívia, Guatemala e Paraguai. A Organização Internacional do Trabalho (OIT), a Organização das Nações Unidas para Agricultura e Alimentação (FAO); a Agência Internacional de Energia Atômica e o Conselho da Europa. United Nations Conference On Consular Relations VienNa A/CONF.25/16. Official Records. Volume I: Summary records of plenary meetings and of the meetings of the First and Second Committees, p. XXV. Vienna, March $4^{\text {th }}-$ April $22^{\text {nd }}, 1963$. Disponível online em: <http://untreaty.un.org/cod/diplomaticconferences/consrelat1963/vol/english/vol_I_e.pdf> (acesso em 28/03/2010).

${ }^{46}$ Os princípios definidos na Conferência sobre Relações Consulares tiveram a vantagem de serem estabelecidos em conformidade com os interesses e pontos de vista de Estados com todos os tipos de sistemas políticos e econômicos - e, assim, ajudar a promover a melhoria das relações no mundo como um todo. A Convenção resultante beneficiou-se muito fruto dos sete anos de trabalho da CDI, cujo Projeto serviu de base para as discussões. ${ }^{46} \mathrm{E}$ tanto a CVRD quanto a CVRC fornecem bases quase universais para as relações inter-Estatais, mas ainda padrões comuns a legislação consular doméstica. A certeza e previsibilidade que resultou da Conferência foram benéficas. Até mesmo Estados que não são partes das convenções, as consideram como sendo declaratórias do direito internacional. Por exemplo, mesmo antes de o Canadá ratificar a CVRD (26/05/1966) e a CCRC (18/07/1974), o Departamento de Relações Exteriores já as consideravam declaratórias do direito internacional. LEE, Luke T. J.D. and QuigLEY, John. Consular Law and Practice, p. 25.
} 
virtude de execução de uma sentença. Todavia, esse direito fica sujeito à vontade do indivíduo, que pode expressamente se opor. Finalmente, o parágrafo $2^{\circ}$ prevê que esses direitos devem ser exercidos em conformidade com as leis e regulamentos do Estado Receptor, que devem garantir total efeito aos propósitos acordados no dispositivo. Isto é, o Estado Receptor não pode alegar uma lei ou norma de direito interno para impedir que o indivíduo detido impugne uma sentença condenatória, com fundamento na violação do artigo 36 da Convenção de Viena sobre Relações Consulares. $^{47}$

Alguns pontos discutidos pelas Delegações, durante a Conferência, merecem ser tratados, referentes às discussões sobre a adoção do artigo 36 do projeto, inclusive a posição da delegação brasileira, chefiada por MÁRIO GIBSON Alves BARBosA. ${ }^{48}$ Enquanto havia concordância geral de que o Estado Receptor deveria garantir o acesso quando requerido, os Estados participantes divergiam sobre se o Estado Receptor devia ser obrigado a notificar o consulado sempre quando da prisão de um nacional do Estado que envia - pelo projeto da Comissão de Direito Internacional das Nações Unidas, sim, conforme o artigo 36 do projeto. Várias objeções à obrigação foram apresentadas. Por exemplo, as delegações das Filipinas e

$47 \mathrm{Na}$ decisão do caso LAGRAND, a Corte Internacional de Justiça desmembra o artigo 36 da Convenção de Viena de 1963. LAGRAND (Germany $\boldsymbol{v}$. United States of America), ICJ Reports of Judgments, Advisory Opinions and Orders, 27/06/2001, par. 90.

48 "77. Mr. GIBSON BARBOZA (Brazil) shared the views of the representative of India. It would be inconceivable to draft a convention which did not include a provision of the kind contemplated in article 36. He had doubts whether any of the proposals before the meeting represented a real effort at compromise, for the concessions made did not go far enough. Nevertheless, he would vote in favor of any of them that were put to the vote rather than see the convention without the article at all." UNITED NATIONS CONFERENCE ON CONSUlAR RELATIONS VIENNA A/CONF.25/16. Official Records. Volume I: Summary records of plenary meetings and of the meetings of the First and Second Committees, p. 84. Vienna, March $4^{\text {th }}-$ April $22^{\text {nd }}, 1963$. Disponível online em: <http://untreaty.un.org/cod/diplomaticconferences/consrelat-1963/vol/english/vol_I_e.pdf> (acesso em 02/04/2010). MÁrio GiBSON Alves BARBosA (Olinda, 13 de março de 1918 — Rio de Janeiro, 26 de novembro de 2007) foi um diplomata brasileiro. Bacharelou-se em Ciências Jurídicas e Sociais pela Faculdade de Direito do Recife em 1937. Em 1939, prestou concurso para o Ministério das Relações Exteriores, ingressando na carreira diplomática. Foi vice-cônsul do Brasil em Houston, Texas e terceiro-secretário da Embaixada brasileira em Washington (Estados Unidos); primeirosecretário da representação brasileira em Bruxelas (Bélgica); ministro-conselheiro em Buenos Aires (Argentina) e junto à Organização das Nações Unidas (ONU); chefe-de-Gabinete do ministro das Relações Exteriores, Afonso Arinos de Melo Franco. Foi, ainda, embaixador do Brasil em Viena (Áustria), em Assunção (Paraguai) e em Washington, e secretário-geral de Política Exterior do Itamaraty. Pela sua gentileza, bons modos e imponência, que faziam lembrar um diplomata do antigo regime, era conhecido no Itamaraty como o Marquês de Olinda, em alusão a cidade onde nasceu. Informação disponível online em: <http://pt.wikipedia.org/wiki/M\%C3\%A1rio_Gibson_Barbosa>, (acesso em 22/03/2011). 
Romênia alegaram que um estrangeiro sujeito à jurisdição do Estado Receptor não poderia clamar por um grau de proteção maior do que a dos nacionais daqueles países; e que o argumento de que os estrangeiros privados de sua liberdade não conheciam as leis criminais do Estado Receptor não seria válido, "as no one was supposed to be ignorant of the Law". Para a Nova Zelândia e a Malásia, o texto não levou em consideração a realidade da enorme quantidade de imigrantes em alguns países, o que tornaria impossível aplicar o artigo 36 da Convenção. ${ }^{49}$ Para a delegação do Equador, a liberdade dos nacionais do Estado que envia de terem acesso aos consulados de seu país, quando privados de sua liberdade, mais combinava com a Declaração Universal de Direitos Humanos do que com uma convenção sobre funções e imunidades consulares.

A delegação da Espanha manifestou que o direito dos cidadãos de um Estado para se comunicar e ter acesso ao consulado e aos funcionários consulares de seu país "é um dos mais sagrados direitos dos estrangeiros residentes no Estado Receptor". O fato de ter sido estabelecido ao abrigo do direito interno, de modo algum conflita com a necessidade de estabelecê-lo nos termos do direito internacional. O representante da delegação do Equador disse que a liberdade dos cidadãos de se comunicar e ter acesso aos seus consulados veio no âmbito da Declaração Universal dos Direitos Humanos e não de uma convenção sobre as relações consulares. O representante da Grécia afirmou que seu país tinha um grande número de cidadãos em diferentes partes do mundo, e estava ansioso para a defesa

\footnotetext{
${ }^{49}$ A delegação da Venezuela, apoiada pela do Kwait, manifestou o seguinte: "The objection to the International Law Commission draft was mainly one of form. The opening statement of subparagraph 1 (a), concerning the right of the nationals of the sending State to communicate with and to have access to the competent consulate, was inappropriate in a convention on consular relations. The Government of Venezuela considered that foreign nationals in the receiving State should be under the jurisdiction of that State and should not come within the scope of a convention on consular relations. (...) an article in a convention on consular relations should not start by referring to the nationals of the sending State." Para a delegação da Austrália, muito embora o acesso consular fosse um direito fundamental para o indivíduo, deveria ser submetido ao desejo do preso: "however, that the fundamental right must be qualified with regard to the wishes of the individual." Para a delegação da Grécia, a inclusão da garantia de acesso consular do artigo 36 para a proteção dos estrangeiros no território do Estado receptor, residentes permanentes ou visitantes temporários, se destina precisamente a evitar futuros abusos e violações de direito internacional por parte das autoridades do Estado receptor.United NATIONS CONFERENCE ON CONSUlAR RELATIONS VIENNA A/CONF.25/16. Official Records. Volume I: Summary records of plenary meetings and of the meetings of the First and Second Committees, pp. 36 - 39, 331-334 Vienna, March $4^{\mathrm{th}}-$ April $22^{\text {nd }}, 1963$. Disponível online em: <http://untreaty.un.org/cod/diplomaticconferences/consrelat-1963/vol/english/vol_I_e.pdf> (acesso em 02/04/2010).
} 
dos seus direitos. A Conferência, em sua tarefa de codificar o direito internacional e costumes sobre as relações consulares, também estava seguindo a tendência atual de promover e proteger os humanos direitos, e as gerações futuras ficariam muito gratas. A Grécia, portanto, atribuiu uma importância muito grande para o artigo 36.

GIBSON BARBOZA, representante da delegação do Brasil, afirmou que seria inconcebível elaborar uma convenção que não incluísse uma disposição do tipo previsto no artigo 36. O representante do Reino Unido disse que o artigo 36 foi uma disposição importante e deveria ser redigida em termos inequívocos, já que envolve um assunto que era ainda mais delicado nos tempos modernos, quando os meios de transportes e viagens estavam se desenvolvendo progressivamente. Por outro lado, notou que o âmbito do artigo foi limitado pelas palavras de abertura: "com vista a facilitar o exercício das funções consulares". Para a delegação suíça a liberdade da pessoa humana e a expressão da vontade do indivíduo são os princípios fundamentais que regem os instrumentos celebrados sob a égide das Nações Unidas, e que o texto a ser elaborado pela Conferência deverá igualmente refletir esses princípios. ${ }^{50}$

No mais, as delegações basicamente discutiram um prazo para a expressão "sem tardar", o que poderia causar um "fardo" para os Estados receptores que recebem um grande número de turistas e residentes permanentes estrangeiros, daí a liberdade de opção do estrangeiro de receber, ou não, a assistência consular na prisão; a necessidade de o estrangeiro consentir com a notificação ao Consulado de sua nacionalidade, sobre sua detenção, a questão dos indocumentados, no caso de verificar sua nacionalidade; a manutenção de uma lista periódica dos presos estrangeiros, para facilitar o trabalho dos Consulados. Lembrando que foi o representante da delegação do Brasil, o Ex-Chanceler GIBSON BARBOSA, que atuou como presidente de mesa nessa sessão. Foi ele quem encerrou os trabalhos de considerações ao Projeto de artigos sobre Relações Consulares, adotados pela Comissão de Direito Internacional das Nações Unidas, na sessão $13^{\mathrm{a}}$ (A/CONF.25/6),

50 United NATions CONFERENCE on CONSUlar Relations VienNa A/CONF.25/16. Official Records. Volume I: Summary records of plenary meetings and of the meetings of the First and Second Committees, pp. 39, 84, 334, 335, 339. Vienna, March $4^{\text {th }}-$ April $22^{\text {nd }}, 1963$. Disponível online em: <http://untreaty.un.org/cod/diplomaticconferences/consrelat-1963/vol/english/vol_I_e.pdf> (acesso em 02/01/2011). 
depois dos agradecimentos costumeiros, em 4 de abril de 1963, no quadragésimoquarto encontro das delegações na Conferência.

A Ata Final da Conferência foi assinada em 24 de abril de 1963. Tanto a Convencao quanto os Protocolos Opcionais da Convenção ficaram abertos à assinatura até 31 de outubro de 1963 no Ministério Federal dos Negócios Estrangeiros da Áustria e, posteriormente, até 31 de março de 1964, na sede das Nações Unidas. Permanecem abertos para adesão por todos os membros da Organização das Nações Unidas ou de qualquer uma das agências especializadas ou Partes do Estatuto da Corte Internacional de Justiça, e de qualquer outro Estado convidado pela Assembléia Geral para se tornar parte. A Convenção e os dois Protocolos Facultativos entraram em vigor em 19 de março de 1967.

A Convenção de Viena sobre Relações Consulares codifica algumas das regras que guiam as relações consulares entre os Estados. Ao fornecer um quadro jurídico internacional para as relações consulares, privilégios e imunidades, a Convenção visa assegurar o eficaz desempenho das funções pelos postos consulares, em nome dos respectivos Estados. Estas funções consulares incluem a promoção do desenvolvimento das relações comerciais, econômicas, culturais e científicas entre os Estados; atuando como tabelião, cartório civil, e emissão de passaportes e documentos de viagem aos nacionais do envio Estado, bem como vistos e documentos apropriados às pessoas que pretendam viajar para o Estado de origem. Visa contribuir para o desenvolvimento de relações amistosas entre as nações, tendo em conta os objetivos e princípios da Carta das Nações Unidas, em particular os relativos à igualdade soberana dos Estados, a manutenção da paz internacional e segurança, e a promoção de relações amistosas entre as nações. 


\section{Capítulo 2}

\section{QUALIFICAÇÃO DO DIREITO DE INFORMAÇÃO SOBRE ASSISTÊNCIA CONSULAR PARA O PRESO ESTRANGEIRO}

A decisão de deixar o próprio país, seja para trabalhar e começar uma nova vida, seja para fazer turismo, geralmente vem acompanhada de dificuldades e obstáculos. Os imigrantes geralmente enfrentam discriminação, coletiva ou individualmente, e podem ficar sujeitos à hostilidade e exploração e, em alguns casos, violações de direitos humanos. Essa vulnerabilidade afeta algumas categorias de imigrantes, sobretudo no mundo totalmente interconectado; ainda mais quando sua situação imigratória é irregular. Daí porque, a proteção desses indivíduos deve ser fortalecida, por meio de mecanismos de prevenção e compensação. Isso pode ser conseguido por meio da proteção e assistência consular - para promover o respeito dos direitos dos estrangeiros e encorajar os Estados, e outros atores, a fazerem melhor uso desse instituto. ${ }^{51}$

Existem vários mecanismos internacionais de proteção, na eventualidade da violação de direitos humanos dos estrangeiros, que podem ser ativados. Um importante mecanismo de proteção aos direitos do estrangeiro, principalmente quando privado de liberdade, parece ter sido negligenciado, tanto como mecanismo de reação quanto de prevenção. A importância do direito de notificação e informação sobre assistência consular para o estrangeiro privado de liberdade foi reacendida quando da apresentação, pelo Paraguai, em 03 de abril de 1998, de pedido de abertura de procedimento contencioso perante a Corte

${ }^{51}$ PERRUCHOUD, Richard. Consular protection and assistance, pp. 71-72. O autor observa que imigrantes sao frequentemente vistos como diferentes, exploráveis, bodes expiatórios, os males da sociedade. É evidente a discriminação no trabalho, educação e outros serviços. 
Internacional de Justiça contra os Estados Unidos, estudado no capítulo seguinte deste trabalho.

A Convenção de Viena sobre Relações Consulares de 1963 codifica algumas das regras costumeiras que guiavam as relações consulares entre Estados, que, até então, estavam dispostas em inúmeros tratados bilaterais e alguns instrumentos regionais. E para IAN BROWNLIE ${ }^{52}$, foi exatamente a existência de práticas uniformes, evidenciado por inúmeros tratados bilaterais, que incentivou a Comissão de Direito Internacional das Nações Unidas a codificar essas práticas. ${ }^{53}$ Possui um forte elemento de desenvolvimento e reconstrução de um direito existente, e estabelece o status dos cônsules de carreira, bem próximo ao dos diplomatas.

Esse tratado internacional que protagoniza o presente estudo representa o maior passo para determinar o status das relações e imunidades consulares. Considerado a "pedra angular" do Direito Consular Internacional, ${ }^{54}$ é composto por 79 artigos, cuja maioria assegura o funcionamento dos consulados,

${ }_{52}^{52}$ BRownlie, Ian. Principles of Public International Law, p. 365.

${ }^{53} \mathrm{O}$ acesso consular aos seus nacionais em situação de privação da liberdade há muito é uma característica da prática da proteção consular. Antes mesmo da CVRC, os EUA concluíram 28 tratados com provisões de acesso consular, por exemplo, com a Algéria, China, Costa Rica, Chipre, Dinamarca, Etiópia, França, Alemanha, Nicarágua, Paquistão, Filipinas, Serra Leoa, Trinidad e Tobago, Uganda, Reino Unido, Vietnã. Os Estados, rotineiramente instruíam seus cônsules a como atenderem seus nacionais presos. Por exemplos, os cônsules haitianos eram treinados para buscar permissão nas autoridades locais para visitarem seus nacionais presos; da mesma forma a Holanda. Os EUA, em nota protesto enviada ao Chile em 1925, sobre a detenção de nacionais americanos lá, manifestaram que "os nacionais americanos, quando presos no exterior,devem ser autorizados a comunicarem-se com representantes diplomáticos ou consulares de seu país". Em 1927 a "Comissão de Reclamação" (EUA-México), no caso de um americano preso durante uma viagem de negócios ao México, constatou que ao americano "não foi permitido por vários dias a comunicação com seu cônsul" e acrescentou que "estrangeiro que não é familiar com as leis do país onde temporariamente reside, deveria ser garantida essa oportunidade", de comunicação com o consulado. A partir daí a "Harvard Research Draft", artigo 11(d), concluiu que o Estado receptor, sob o direito costumeiro, deve permitir que o cônsul visite seus nacionais quando eles forem presos ou detidos pelas autoridades do Estado receptor. Considerações de reciprocidade motivaram os Estados a aceitarem o acesso consular. Quando em 1934 o México reclamou que os oficiais da Califórnia não permitiram a visita do Cônsul mexicano ao seu nacional preso, o Departamento de Estado dos EUA informou ao governo da Califórnia que: "mesmo na ausência de tratado aplicável, este Governo sempre insistiu pela permissão dos cônsules para visitarem americanos presos ao redor do mundo, e crê-se que se a atitude do promotor for mantida, no caso em apreço haverá repercussões no México, e talvez em outros países, desfavoráveis aos cidadãos americanos. É seriamente requerido que seja tomada ação imediata para reverter essa posição". Por outro lado, o Japão considerava que um cônsul poderia visitar um nacional preso no Estado receptor por u ma questão de "cortesia internacional", e não por um direito ou costume, da mesma forma o Reino Unido. LEE, Luke T. J.D. and QUIGLEY, John. Consular Law and Practice, pp. 140-142.

${ }^{54}$ PERRUCHOUD, Richard. Consular protection and assistance, p. 74. 
delineia as funções de agentes consulares, que são muitas e variadas e incluem a proteção dos interesses do Estado que envia e de seus nacionais, os privilégios e imunidades. E ao fornecer um quadro jurídico internacional para as relações consulares, privilégios e imunidades, a Convenção visa assegurar o eficaz desempenho das funções pelos postos consulares, em nome de seus respectivos Estados.

A assistência e proteção consular ${ }^{55}$ são consideradas como sendo parte da Política Externa do Estado, visando a proteção dos interesses de seus nacionais no exterior. Recebe o título de Cônsul o funcionário de um Estado que envia responsável, em país estrangeiro, o Estado Receptor, pela proteção dos interesses dos indivíduos e empresas que sejam nacionais daquele Estado. Ele atua na órbita dos interesses privados proncipalmente dos seus compatriotas, mas também e de estrangeiros nacionais do Estado em que atua. Representa os interesses do Estado que é nacional, mas não no sentido político, como faz a Missão Diplomática.

É o artigo $5^{\circ}$ da Convenção de Viena sobre Relações Consulares que indica claramente no que consistem as funções exercidas pelo cônsul; que a proteção e assistência oferecida a um estrangeiro, pessoa física ou jurídica, para a defesa de seus direitos perante as autoridades do Estado Receptor. O direito de proteção e assistência consular também pode ser visto como uma consequência lógica do dever do Estado de proteger os direitos de seus nacionais, onde quer que estejam no exterior, assim como dos estrangeiros que se encontram em seu território, independentemente de seus status imigratório. ${ }^{56}$

\footnotetext{
55 Proteção consular é geralmente entendida como aplicável a casos concernentes a uma reclamação contra um ofical do governo por alegada infração a um direito de um estrangeiro. Assistência consular, por outro lado, é geralmente vista não como para corrigir um erro, mas como resposta a um estado de necessidade no qual os estrangeiros se encontram: assistência a doentes, pagamento de pensão, informação sobre estrangeiros detidos, retorno ao país de origem de estrangeiros em necessidade, assistência no caso de deportação e medidas semelhantes. No entanto, geralmente proteção e assistência consular são usadas alternadamente, ou lado a lado, sem nenhuma distinção. Outra distinção também é feita entre proteção e assistência consular ativa e passiva. Aquela é a exercida no Estado receptor pelos representantes consulares do Estado que envia, conforme as provisões da CVRC; enquanto que esta refere-se a exercida pelos representantes consulares de outros Estados nesse mesmo Estado que envia. Desta forma, enquanto a atividade de proteção consular é uma atividade do Estado com respeito a seus próprios nacionais em territórios de outros Estados, a forma passiva refere-se a esse Estado permitindo que outros façam o mesmo em seu território; uma diferença de perspectiva. PERRUCHOUD, Richard. Consular protection and assistance, p. 76.

${ }^{56}$ PERRUCHOUD, Richard. Consular protection and assistance, p. 76.
} 
Os funcionários consulares representam seu Estado de muitas formas administrativas, por exemplo, na emissão de vistos e passaportes e, em geral, promovem os interesses comerciais do seu Estado. Não podem é intervir no processo judicial ou assuntos internos do Estado, receber ou dar aconselhamento jurídico ou investigar um crime. As Repartições Consulares baseiam-se não apenas nas capitais dos Estados receptores, mas também em outras cidades importantes. No entanto, a rigor não exercem funções políticas. Portanto, aos funcionários consulares não é concedido o mesmo grau de imunidade de jurisdição como a dos diplomatas.

A Corte Internacional de Justiça, no julgamento do caso dos REFÉnS EM TEER $\tilde{A}^{57}$, ressaltou que a instituição da diplomacia, com seus privilégios e imunidades concomitantes, tem resistido ao teste dos séculos e provou ser um instrumento essencial para uma cooperação efetiva no seio da comunidade internacional, e para permitir que os Estados, independentemente de seus regimes constitucionais e sociais, alcancem a compreensão mútua, e resolvam suas diferenças por meios pacíficos. Ainda, que a conduta livre também das relações consulares, que também foi estabelecida entre os povos, desde os tempos antigos, não é menos importante no contexto da atual legislação internacional, na promoção do desenvolvimento de relações amistosas entre as nações, e garantia da proteção e assistência aos estrangeiros residentes nos territórios de outros Estados, e que, portanto, "os privilégios e imunidades dos funcionários consulares e empregados consulares, assim como a inviolabilidade das instalações consulares e arquivos, são igualmente princípios profundamente enraizado no direito internacional." As obrigações dos Estados Acreditados (denominação utilizada conforme a Convenção de Viena dobre Relações Diplomáticas de 1961) e Estados Receptores (linguagem utilizada conforme a Convenção de Viena sobre Relações Consulares de 1963), não

\footnotetext{
57 "Whereas the unimpeded conduct of consular relations, which have also been established between peoples since ancient times, is no less important in the context of present-day international law, in promoting the development of friendly relations among nations, and ensuring protection and assistance for aliens resident in the territories of other States; and whereas therefore the privileges and immunities of consular officers and consular employees, and the inviolability of consular premises and archives, are similarly principles deep-rooted in international law". INTERNATIONAL COURT OF JUSTICE. United States Diplomatic and Consular Staff in Tehran (United States of America v. Iran). Reports of Judgments, Advisory Opinions and Orders, Judgment of December, $15^{\text {th }}, 1970$, parágs. 39 e 40.
} 
são apenas obrigações contratuais, mas também obrigações decorrentes do direito internacional geral.

Diplomacia é a arte de representar o Estado, uns perante os outros, ou o conjunto de regras práticas referentes às relações pacíficas e as negociações entre os Estados - uma dimensão da política externa do Estado. O diplomata desempenha suas funções junto ao governo central; e atua em todo o território do Estado Acreditado - ele representa o Estado de origem junto à soberania local, e para o trato bilateral dos assuntos de Estado. O cônsul, à seu turno, representa o Estado de origem com o intuito de atender, no território em que atue, aos interesses privados de seus compatriotas que ali se encontrem ou aos nacionais que pretendam visitar aquele país, ou estabelecer negociações comerciais. Ele não tem aspecto representativo no sentido político, e atua junto às autoridades locais, e no raio da sua jurisdição consular. Daí porque suas imunidades são limitadas, em comparação com o diplomata.

Tanto o diplomata quanto o cônsul desempenham funções que representam os interesses do Estado que envia. Os cônsules devem possuir uma comissão do Estado que envia e uma autorização (exequatur) do Estado Receptor (já o diplomata recebe a Carta-Patente). Funcionários consulares têm direito à mesma isenção de impostos e deveres aduaneiros, assim como os diplomatas. Igualmente usufruem de inviolabilidade física e de imunidade ao processo penal ou cível, mas apenas no tocante aos atos de ofício. Vale destacar, que estes privilégios, assim limitados, não se estendem aos membros familiares e nem a instalações residenciais (salvo a residência do cônsul quanto à isenção de impostos). A imunidade penal dos cônsules, por ser limitada aos atos de ofício, autoriza, nos casos de crimes comuns, que sejam processados e punidos no local, devendo o Estado Receptor respeitar, ao máximo, a posição e as funções do cônsul e o andamento dos postos consulares. Não são puníveis, pois, pelo Estado local, os crimes relacionados com a função consular, tais como fraudes em passaportes, guias de exportação, entre outros. ${ }^{58}$

${ }^{58}$ SHAW, Malcon. International Law, pp. 725 e 772. Arts. 31, e 35, 41, 43 da CVRC. 
O cônsul desenvolve diferentes funções e possui status diferente do diplomata. Segundo a legislação brasileira, não existe carreira consular. O cônsul é, simplesmente, o título atribuído ao chefe de um Consulado, que pode ser um Embaixador ou, eventualmente, um Ministro da carreira diplomática. Há também o título de Cônsul-Adjunto, atribuído ao diplomata (ou diplomatas) subordinado(s) ao cônsul. Um funcionário administrativo do Ministério (como Oficial de Chancelaria ou Assistente de Chancelaria) que trabalhe em um Consulado pode receber o título de vice-cônsul.

Há, por fim, o cônsul honorário, brasileiro ou estrangeiro indicado pelo Governo brasileiro para coordenar algumas das atividades atribuídas a um Consulado em uma cidade ou região onde não há consulado brasileiro. Ressalta-se que esses títulos (cônsul, cônsul-adjunto, vice-cônsul) não guardam relação com os cargos da carreira diplomática (Embaixador, Ministro, Conselheiro, Secretário) e sim com as funções exercidas pelos diplomatas em um Consulado do Brasil no exterior.

O cônsul representará o Governo brasileiro perante as autoridades de sua jurisdição e junto aos brasileiros residentes ou de passagem, respeitada a competência da Missão Diplomática brasileira no país sede da mesma. Ele desempenha uma miríade de funções, que incluem a proteção dos interesses do Estado que envia e de seus nacionais, tais como: promover o desenvolvimento de relações comerciais, econômicas, culturais e científicas entre o Estado que envia e o Estado Receptor; atua na qualidade de notário e registrador civil e capacidades semelhantes; na emissão de passaportes e documentos de viagem aos nacionais do Estado que envia, e de vistos e documentos apropriados às pessoas que pretendam viajar para o Estado que envia; registro de nascimentos, casamentos e óbitos. Poucos artigos especificam outras funções dos funcionários consulares relacionadas aos cidadãos de seu país que enfrentam dificuldades em uma nação estrangeira. ${ }^{59}$

\footnotetext{
${ }^{59}$ Por outro lado, a Convenção de Viena sobre Relações Diplomáticas de 1961, promulgada pelo Brasil por força do Decreto $n^{\circ} 56.435$, de 8 de junho de 1965, dispõe em seu artigo $3^{\circ}$ que as funções de uma missão diplomática consistem, entre outras, em: a) representar o Estado acreditante perante o Estado acreditado; b) proteger no Estado acreditado os interesses do Estado acreditante e se seus nacionais, dentro dos limites permitidos pelo direito internacional; c) negociar com o Governo do Estado acreditado; d) inteirar-se por todos os meios lícitos das condições existentes e da evolução dos acontecimentos no Estado acreditado e informar a este respeito o Governo do Estado acreditante; e) promover relações amistosas e desenvolver as relações econômicas, culturais $e$
} 
Conforme o especialista em Direito Consular LUKE T. LEE ${ }^{60}$, a proteção de nacionais é a função mais básica do cônsul, função sagrada, consumindo a maior parte do trabalho nas Repartições Consulares. E o motivo é simples: cada vez aumenta mais o número de nacionais que viaja ou reside no exterior. Ele destaca a assistência consular aos nacionais em situação de privação de liberdade no Estado em que mantêm a Repartição Consular ${ }^{61}$, a atividade em resposta a seqüestros internacionais de menores; assistência a refugiados; e a proteção, em certas situações, de não-nacionais. O Estado receptor da repartição consular tem a obrigação, em geral, de permitir e facilitar essas atividades em seu território. ${ }^{62}$

cientificas entre o Estado acreditante e o Estado acreditado. 2. Nenhuma disposição da presente Convenção poderá ser interpretada como impedindo o exercício de funçães consulares pela Missão diplomática." Sobre a adoção da expressão "Estado acreditante", ao invés de "Estado que envia", para NASCIMENTO E SILVA, a eventual relutância em acolher esses neologismos, acolhidos no texto oficial brasileiro é compreensível, havendo sido hesitado da mesma forma pelas delegações francesa e espanhola. Para ele, a verdade é que na elaboração de tratados internacionais em que existem duas ou mais línguas oficiais (no caso temos cinco línguas oficiais), concessões lingüísticas têm que ser feitas, com o objetivo de uniformizar, na medida do possível, as várias versões assinadas, cabendo à doutrina aceitar e divulgar as inovações introduzidas. NASCIMENTo E Silva, G. E. de. Diplomacia e Protocolo, pp. 12-13. Assim, podemos identificar a diferença crucial entre as funções das missões diplomáticas e das repartições consulares: a embaixada representa os interesses e a soberania de um Estado (acreditante) perante outro Estado (acreditado); enquanto que o consulado representa, no Estado receptor, os interesses particulares dos nacionais, pessoas físicas ou jurídicas, no Estado que envia. O funcionário consular não representa o seu Estado perante o governo do país onde reside; atua na órbita dos interesses privados dos seus compatriotas. Outra diferença crucial é que, ao contrário dos diplomatas chefe da missão e seus membros, os Cônsules e funcionários consulares usufruem de inviolabilidade física e de imunidade ao processo penal ou cível, apenas no tocante aos atos de ofício. Ainda, de acordo com o artigo 70 da CVRC, é possível o exercício de funções consulares pelas missões diplomáticas na seguinte forma: "1. As disposições da presente Convenção aplicar-se-ão também, na medida em que o contexto o permitir, ao exercício das funções consulares por missões diplomáticas. 2. Os nomes dos membros da missão diplomática, adidos à seção consular ou encarregados do exercício das funções consulares da missão, serão comunicados ao Ministério das Relações Exteriores do Estado receptor ou à autoridade designada por este Ministério. 3. No exercício das funções consulares, a missão diplomática poderá dirigir-se: a) às autoridades locais da jurisdição consular; b) às autoridades centrais do Estado receptor, desde que o permitam as leis, regulamentos e usos desse Estado ou os acordos internacionais pertinentes. 4. Os privilégios e imunidades dos membros da missão diplomática mencionados no parágrafo $2^{\circ}$ do presente artigo continuarão a reger-se pelas regras de direito internacional relativas às relações diplomáticas".

${ }^{60}$ LeE, Luke T. J.D. and QuigLeY, John. Consular Law and Practice, pp. 116 e 131.

${ }^{61} \mathrm{O}$ "Estado que envia" é o qual é nacional a pessoa privada de sua liberdade (artigo 36.1. "b" da CVRC). Por sua vez, o "Estado Receptor" é o que priva a liberdade do indivíduo nacional do "Estado que envia".

${ }^{62} \mathrm{O}$ falecido Secretário-Geral das Relações Exteriores austríaco, o Sr. HEINRICH WILDNER, que recebeu o treinamento no serviço diplomático da monarquia austro-húngara, salientou em seu Manual sobre o Método Diplomático, que o serviço consular exigiria, pelo menos, o mesmo objeto de formação do serviço diplomático apropriado, e possivelmente até mesmo um treinamento mais intensivo. Talvez uma mina ainda mais rica de experiências, porque os membros do consulado estão mais diretamente em contato com a administração e a população do Estado Receptor, daí também com suas vidas e cultura. United NATIONS CONFERENCE ON CONSUlar RELATIONS VIENNA A/CONF.25/16. Official Records. Volume I: Summary records of plenary meetings and of the meetings of the First and Second Committees, parág. 13. Vienna, March $4^{\text {th }}-$ April $22^{\text {nd }}, 1963$. 
Ao contrário das Missões Diplomáticas, cuja função primordial é representar a soberania e os interesses do Estado perante outro, os Consulados representam e protegem interesses particulares. ${ }^{63}$ As regras do direito diplomático, em suma, constituem um regime autônomo que, por um lado, igualmente recebe facilidades, privilégios e imunidades que serão concedidos às missões diplomáticas. O princípio da inviolabilidade é um dos alicerces deste sistema, um costume estabelecido desde a Antiguidade.

A grande importância do serviço consular reside justamente no fato de que o contato dos consulados com as autoridades do Estado Receptor é geralmente mais estreito do que o destinado às embaixadas, restrito às autoridades locais, devido à própria natureza das funções atribuídas aos cônsules e seus assistentes. Os funcionários consulares não estão em contato não apenas com funcionários e diplomatas do Estado ao qual servem, mas, principalmente, com seus nacionais que estão no Estado Receptor, não raro em situação de vulnerabilidade, e buscando na Repartição Consular informação, aconselhamento e apoio. ${ }^{64}$

\footnotetext{
Disponível online em: <http://untreaty.un.org/cod/diplomaticconferences/consrelat1963/vol/english/vol_I_e.pdf> (acesso em 30/03/2010).

${ }^{63}$ E sobre o Direito Diplomático, Malcolm Shaw explica que a Diplomacia, como método de comunicação entre as várias partes, incluindo as negociações entre os agentes reconhecidos, é uma instituição antiga, e as disposições jurídicas internacionais que regem as suas manifestações resultam de séculos de práticas do Estado. Os privilégios e imunidades relativas ao pessoal diplomático de vários tipos cresceu em parte como consequência da imunidade soberana e da independência e igualdade dos Estados, e em parte como um requisito essencial de um sistema internacional. Os Estados devem negociar e consultar uns com os outros, e com as organizações internacionais, e fazem isso por meio dos funcionários diplomáticos, o que beneficia o princípio jurídico da soberania do Estado. SHAw, Malcon. International Law, p. 750.

64 Além das funções especificadas no artigo $5^{\circ}$ da Convenção de Viena sobre Relações Consulares compete, ainda, à Autoridade Consular: 1) efetuar matrículas e expedir as respectivas cédulas; 2) providenciar a repatriação de brasileiros, quando for o caso; 3) agir na qualidade de oficial do Serviço Militar; 4) praticar atos que a legislação eleitoral determinar; 5) atuar como agente receptor de Declarações de Rendimento de brasileiros residentes no exterior, de acordo com instruções expedidas, anualmente, pelo Ministério da Fazenda; 6) encaminhar processos de perda e de reaquisição de nacionalidade brasileira; e 7) encaminhar pedidos de naturalização de estrangeiros e entregar o respectivo Certificado de Naturalização. Caberá igualmente à Autoridade Consular: 1) prestar assistência aos brasileiros que se acharem envolvidos em processos criminais; 2)estabelecer contatos com diretores de penitenciárias situadas em sua jurisdição e manter relação atualizada de presos brasileiros; 3) caso solicitado, servir de ligação entre os prisioneiros e suas famílias, seja no Brasil ou no exterior; e 4) nos postos onde é elevado o número de prisioneiros brasileiros, inteirar-se das condições de saúde e das instalações onde estejam detidos e, ainda, instruir funcionário a visitar periodicamente os prisioneiros, mantendo fichário atualizado e enviando relatórios periódicos. República Federativa do Brasil. Ministério das Relações Exteriores. Subsecretaria-Geral das Comunidades Brasileiras no Exterior. Manual do Serviço Consular e Jurídico. Capítulo 2, item 2.1.9 e Capítulo 3 item 3.1.20, disponível online em: http://www2.mre.gov.br/mre_port/manualdcj1.htm> (último acesso em 10/07/2011).
} 
Uma importante função de proteção do funcionário consular, que fundamenta o tema estudado neste trabalho, é justamente a disposta no artigo 36 da Convenção: a comunicação com nacionais em qualquer situação de privação de liberdade, preventivamente ou definitivamente, ou resultado de uma sentença condenatória. Quando os nacionais do Estado que envia enfrentam alguma dificuldade criminal no exterior, são presos de qualquer maneira, acusados de terem cometido algum delito no Estado Receptor, e sentenciados, os funcionários consulares podem visitá-los na prisão para garantir que estão sendo tratados de forma apropriada. Se for aplicável algum tratado de transferência de preso, o cônsul pode facilitar a transferência do nacional para o Estado ao qual é nacional. O funcionário consular também pode prestar assistência a seus nacionais durante o tempo em que forem presos, no seu julgamento, para assegurar que seus direitos sejam protegidos e seja usufruido plenamente o direito de ampla defesa. As dificuldades surgem quando as autoridades competentes do Estado Receptor dificultam a comunicação entre o estrangeiro preso e o funcionário consular de seu país de origem.

O artigo 36 da Convenção de Viena sobre Relações Consulares de 1963 prevê uma situação especial de proteção e assistência consular, e refere-se à qualquer forma de privação da liberdade de um estrangeiro pelas autoridades competentes do Estado Receptor ${ }^{65}$, dispondo o seguinte:

\footnotetext{
${ }^{65}$ A Convenção Internacional sobre a Proteção dos Direitos de Todos os Trabalhadores Imigrantes e Membros das Suas Famílias, firmada em 18 de dezembro de 1990, havendo entrado em vigor em $1^{\circ}$ de julho de 2003, após a vigésima ratificação, possui um Comitê de cumprimento e implementação, e compõe o corpo de tratados internacionais de direitos humanos sob os auspícios da ONU, $69^{\mathrm{a}}$ Assembléia Geral, 18 de Dezembro de 1990. A/RES/45/158. O artigo 16(5-9) da Convenção assim dispõe: “(... 5. Migrant workers and members of their families who are arrested shall be informed at the time of arrest as far as possible in a language they understand of the reasons for their arrest and they shall be promptly informed in a language they understand of any charges against them. 6. Migrant workers and members of their families who are arrested or detained on a criminal charge shall be brought promptly before a judge or other officer authorized by law to exercise judicial power and shall be entitled to trial within a reasonable time or to release. It shall not be the general rule that while awaiting trial they shall be detained in custody, but release may be subject to guarantees to appear for trial, at any other stage of the judicial proceedings and, should the occasion arise, for the execution of the judgment. 7. When a migrant worker or a member of his or her family is arrested or committed to prison or custody pending trial or is detained in any other manner: (a) The consular or diplomatic authorities of his or her State of origin or of a State representing the interests of that State shall, if he or she so requests, be informed without delay of his or her arrest or detention and of the reasons therefor; (b) The person concerned shall have the right to communicate with the said authorities. Any communication by the person concerned to the said authorities shall be forwarded without delay, and he or she shall also have the right to receive communications sent by the said authorities without delay; (c) The person concerned shall be informed without delay of this right and of rights deriving from relevant treaties, if any, applicable between the States concerned, to
} 
1. A fim de facilitar o exercício das funções consulares relativas aos nacionais do Estado que envia:

a) os funcionários consulares terão liberdade de se comunicar com os nacionais do Estado que envia e visitá-los. Os nacionais do Estado que envia terão a mesma liberdade de se comunicarem com os funcionários consulares e de visitá-los;

b) se o interessado lhes solicitar, as autoridades competentes do Estado receptor deverão, sem tardar, informar a repartição consular competente quando, em sua jurisdição, um nacional do Estado que envia for preso, encarcerado, posto em prisão preventiva ou detido de qualquer outra maneira. Qualquer comunicação endereçada à repartição consular pela pessoa detida, encarcerada ou presa preventivamente deve igualmente ser transmitida sem tardar pelas referidas autoridades. Estas deverão imediatamente informar o interessado de seus direitos nos termos do presente sub-parágrafo;

c) os funcionários consulares terão direito de visitar o nacional do Estado que envia, o qual estiver detido, encarcerado ou preso preventivamente, conservar e corresponder-se com ele, e providenciar sua defesa perante os tribunais. Terão igualmente o direito de visitar qualquer nacional do Estado que envia encarcerado, preso ou detido em sua jurisdição em virtude de execução de uma sentença. Todavia, os funcionários consulares deverão abster-se de intervir em favor de um nacional encarcerado, preso ou detido preventivamente, sempre que o interessado a isso se opuser expressamente.

2. As prerrogativas a que se refere o parágrafo $1^{\circ}$ do presente artigo serão exercidas de acordo com as leis e regulamentos do Estado receptor, devendo, contudo, entender-se que tais leis e regulamentos não poderão impedir o pleno efeito dos direitos reconhecidos pelo presente artigo.

O parágrafo 1(a) do dispositivo dispõe que os funcionários consulares são livres para se comunicarem com seus nacionais no Estado Receptor e terem acesso a eles, enquanto esses indivíduos devem ter a mesma liberdade de comunicação e acesso aos funcionários consulares da repartição representante de seu país. Particularmente, o artigo 36.1 (b) dispõe que se um nacional assim requerer, as

correspond and to meet with representatives of the said authorities and to make arrangements with them for his or her legal representation. 8. Migrant workers and members of their families who are deprived of their liberty by arrest or detention shall be entitled to take proceedings before a court, in order that that court may decide without delay on the lawfulness of their detention and order their release if the detention is not lawful. When they attend such proceedings, they shall have the assistance, if necessary without cost to them, of an interpreter, if they cannot understand or speak the language used. 9. Migrant workers and members of their families who have been victims of unlawful arrest or detention shall have an enforceable right to compensation." 
autoridades do Estado Receptor devem, sem tardar, informar à Repartição Consular do Estado que envia sobre qualquer forma de privação de liberdade daquele. Prevê, ainda, o direito dos funcionários consulares de visitar o seu nacional que estiver detido e providenciar a sua defesa perante os tribunais. As autoridades em questão devem informar ao nacional do Estado que envia, sem tardar, sobre esses seus direitos. Semelhantemente, qualquer comunicação do preso deve ser remetida à Repartição Consular "sem demora”. É a linguagem do artigo 36.1(c) que confere ao Estado que envia o direito de representar seus nacionais por violações dos seus direitos em foros internacionais. ${ }^{66}$

Na etapa seguinte deste estudo, constata-se que pela decisão do caso LAGRAND, prolatada em 27 de junho de 2001, a Corte tem a oportunidade de interpretar a "natureza inter-relacionada" existente entre as alíneas "(a), (b) e (c)" do parágrafo $1^{\circ}$ do artigo 36 da Convenção, que acarreta na "interdependência" entre os direitos do Estado que envia e de seus nacionais. ${ }^{67}$ Juntas, as alíneas estabelecem que o indivíduo tem o direito de ser informado, sem tardar, pela autoridade que o detém, sobre seu direito de comunicação consular; tendo esse indivíduo o direito de escolher se o Consulado de seu país deverá ser notificado sobre sua detenção, ou não. Tem ainda o direito de seu Consulado ser informado, e sem demora, pela autoridade que o privou de liberdade; de se comunicar livremente com o representante consular de seu país; de aceitar ou, inclusive, recusar a assistência consular. E quanto ao Estado que envia, o artigo 36 confere ao Consulado o direito de se comunicar e ter acesso ao seu nacional detido; de ser informado, sem demora, sobre a detenção de um nacional seu,

\footnotetext{
${ }^{66}$ Se o detento quer o seu consulado notificado, a notificação deve ser feita na primeira oportunidade conveniente - geralmente dentro de 24 horas após a prisão. A maneira mais fácil para notificar o consulado é via fax. Faxes podem ser enviadas 24 horas por dia, e a folha de confirmação de fax fornece um registro escrito fácil que a notificação foi feita e, assim, o tratado foi cumprido. Consular Notification and Access. COOKE, Rachel L. Disponível online em: http://www.oregon.gov/DPSST/RT/docs/ConsularNotificationAccess/FinalArticle.pdf?ga=t

67 "The Court notes that Article 36, paragraph $1(b)$, spells out the obligations the receiving State has towards the detained person and the sending State. It provides that, at the request of the detained person, the receiving State must inform the consular post of the sending State of the individual's detention "without delay". It provides further that any communication by the detained person addressed to the consular post of the sending State must be forwarded to it by authorities of the receiving State "without delay". Significantly, this subparagraph ends with the following language: "The said authorities shall inform the person concerned without delay of his rights under this subparagraph" (emphasis added). Moreover, under Article 36, paragraph 1 (c), the sending State's right to provide consular assistance to the detained person may not be exercised "if he expressly opposes such action". LAGRAND (Germany v. United States of America), ICJ Reports of Judgments, Advisory Opinions and Orders, 27/06/2001, parag. 77, p. 494.
} 
conforme o seu desejo, de visitar e se corresponder com esse indivíduo, em todos as fases do processo; de arranjar para esse indivíduo, representação jurídica; de garantir-lhe outras formas de assistência humanitária, protetiva, ou jurídica, com o consentimento do indivíduo em questão.

A assistência consular garante ao estrangeiro privado de sua liberdade um melhor entendimento sobre o sistema jurídico do Estado Receptor ao qual está sujeito, e garante melhor acesso a um sistema de apoio psicológico e emocional. Além de servirem como um contato cultural para esses estrangeiros detidos, ao providenciar acesso a referências culturais de seu país, os funcionários consulares podem providenciar representação jurídica, auxiliando na efetivação da defesa do estrangeiro, ao providenciar um advogado bilíngüe adequado e competente para o caso, e na busca por provas atenuantes inclusive no território do Estado que envia, de onde o preso é nacional, o que pode ser decisivo no procedimento criminal. ${ }^{68}$

Por meio da assistência consular, pode-se fornecer advogado e intérprete pessoal para a fase pré-processual conhecida como inquisitorial, para o acompanhamento da lavratura de atos procedimentais, principalmente em relação àqueles relativos ao interrogatório policial e ao indiciamento. No curso da ação penal, o acusado estrangeiro não pode interferir na nomeação de intérprete pelo Juiz, que cumpre a função de perito, mas outro intérprete fornecido pelo Consulado permite que o estrangeiro, sofrendo um processo criminal, entenda e conheça, juntamente com seu advogado nomeado ou dativo, certos direitos, como o de ficar calado e de não responder perguntas que lhe forem formuladas, e que esse direito de silêncio não lhes importará em confissão, e não poderá ser interpretado em prejuízo da defesa. O juiz deve respeitar a sua liberdade de defender-se como preferir: falando ou calando-se. ${ }^{69}$.

\footnotetext{
${ }^{68}$ Tranel, Adrienne M. The Ruling of the International Court of Justice in Avena and other Mexican Nationals, pp. 411-412.

${ }^{69}$ Inciso LXII do artigo $5^{\circ}$ da CF: LXIII - "o preso será informado de seus direitos, entre os quais o de permanecer calado, sendo-lhe assegurada a assistência da família e de advogado". A CF denota sua preocupação inicial com a pessoa capturada - essas garantias lhe são asseguradas mesmo fora e antes do interrogatório.
} 
Ademais, a assistência consular pode facilitar a coleta de registros, documentos e outras provas para garantir a ampla defesa na instrução do processo, e apresentando eventuais atenuantes e minorantes na fase de condenação penal. Pode ainda proporcionar a comunicação com familiares e amigos, além de financiar transporte para membros da família e testemunhas. Sem falar do encaminhamento para tradução dos autos para a língua do acusado estrangeiro para que ele próprio entenda o teor de sua acusação. É por tudo isso que a assistência consular, em se tratando de preso estrangeiro, representa uma função que pode contribuir significdamente na garantia do devido processo legal, principalmente quanto à ampla defesa e contraditório. ${ }^{70}$

Os estrangeiros submetidos a um procedimento penal, em especial quando se vêem privados de liberdade, devem contar com medidas de reforço, que lhes permitam um verdadeiro e pleno acesso à justiça. Não basta que a lei lhes reconheça os mesmos direitos que os demais indivíduos nacionais do Estado em que segue o juízo, mas devem comparecer em pé de igualdade perante a justiça, sem as graves limitações que implicam a estranheza cultural, a ignorância do idioma, o desconhecimento do sistema processual, e outras restrições de suas possibilidades de defesa, sendo necessárias vias de compensação que garantam o acesso à justiça, e conteúdo real ao devido processo legal. E os direitos e garantias que integram o devido processo leal - jamais uma realidade esgotada, se não um sistema dinâmico, em constante formação, são partes necessárias de um conjunto, daí incluído o direito do preso estrangeiro de ser informado sobre o direito que possui de recorrer à proteção consular. $^{71}$

\footnotetext{
${ }^{70}$ O direito do réu à observância, pelo Estado, da garantia pertinente ao "due process of law", além de traduzir expressão concreta do direito de defesa, também encontra suporte legitimador em Convenções internacionais que proclamam a essencialidade destas a franquia processual, que compõe o próprio estatuto constitucional do direito de defesa, enquanto complexo de princípios e de normas que amparam qualquer acusado em sede de persecução criminal, mesmo que se trate de réu estrangeiro, sem domicílio em território brasileiro, aqui processado por suposta prática de delitos a ele atribuídos. HC 94016 / SP - São Paulo Habeas Corpus. Relator: Min. Celso de MelloJulgamento: 16/09/2008 - Órgão Julgador: Segunda Turma.

${ }^{71}$ Opinión Consultiva OC-16/99 del 1 de octubre de 1999. El Derecho a la Información sobre la Asistencia Consular en el Marco de las Garantías del Debido Proceso Legal, Voto concordante do JUIZ SÉRGIO GARCIA RAMIREZ, pp. 02 e 03.
} 
Outros instrumentos internacionais contêm previsões sobre a proteção e assistência consular, como, por exemplo, a Convenção Relativa às Infrações e a Certos Outros Atos Cometidos a Bordo de Aeronaves de $1963^{72}$; o artigo $7^{\circ}$ "a”, da Convenção Internacional sobre a Proteção dos Direitos de Todos os Trabalhadores Migrantes e dos Membros das suas Famílias, Adotada pela Resolução 45/158, de 18 de Dezembro de 1990, da Assembléia-Geral (entrada em vigor a 1 de Julho de $2003)^{73}$. O artigo 14 da Convenção Internacional sobre a Supressão de Atentados Terroristas com Bombas de $1997^{74}$; o artigo 16 (5) do Protocolo contra o Contrabando de Migrantes por Terra, Mar e Ar, complemento da Convenção das Nações Unidas contra o crime Organizado Transnacional, Nova York: ONU, 20005; a Resolução 43/173 da Assembléia Geral da ONU, de 9 de dezembro de 1988, que prevê o Conjunto de Princípios para a Proteção de todas as Pessoas Sujeitas a Qualquer Forma de Detenção ou Prisão ${ }^{76}$; a Declaração das Nações Unidas sobre os Direitos Humanos dos Indivíduos que não são Nacionais do País em que Vivem,

\footnotetext{
${ }^{72}$ Foi assinada pelo Brasil em 28 de fevereiro de 1969, tendo o instrumento de ratificação sido depositado em 14 de janeiro de 1970. Entrou em vigor para o Brasil em 14 de abril de 1970, e foi promulgada pelo Decreto $n^{\circ} 66.520$, de 30 de abril de 1970, cujo artigo 13 (3) dispõe: "Todo Estado contratante deverá receber qualquer pessoa que o comandante da aeronave lhe entregar, de conformidade com o disposto no artigo $9^{\circ}$, parágrafo $1^{\circ}$. À pessoa detida, de conformidade com o parágrafo anterior, será assegurada toda facilidade para se comunicar imediatamente com o representante correspondente do Estado de sua nacionalidade que se encontrar mais próximo.

${ }^{73}$ Artigo 7." No caso de sujeição de um trabalhador migrante ou membro da sua família a detenção ou prisão preventiva, ou a qualquer outra forma de detenção: a) As autoridades diplomáticas ou consulares do seu Estado de origem ou de um Estado que represente os interesses desse Estado são informadas sem demora, se o interessado assim o solicitar, da sua detenção ou prisão e dos fundamentos dessa medida".

${ }_{74}$ Artigo 14: "Toda pessoa que estiver detida ou a respeito da qual se adote qualquer medida ou procedimento com base nesta Convenção terá a garantia de tratamento justo, inclusive o usufruto de todos os direitos e garantias de conformidade com a lei do Estado em cujo território estiver, e os dispositivos aplicáveis do direito internacional, inclusive o direito internacional em matéria de direitos humanos". Assinada em Nova York, em 15/12/1997. Aprovada no Brasil pelo Decreto Legislativo n. ${ }^{\circ} 116$, de 12/06/2002, com reserva ao parágrafo $1^{\circ}$ do Artigo 20. Promulgada pelo Decreto n. ${ }^{\circ} 4388$, de 25 de setembro de 2002. Entrou em vigor para o Brasil em 22/09/2002, e internacionalmente em 01/07/2002.

${ }^{75} 5$. In the case of the detention of a person who has been the object of conduct set forth in article 6 of this Protocol, each State Party shall comply with its obligations under the Vienna Convention on Consular Relations1963, where applicable, including that of informing the person concerned without delay about the provisions concerning notification to and communication with consular officers.

${ }^{76}$ Artigo 16.2: No caso de um estrangeiro, este será igualmente informado sem demora do seu direito de se comunicar, por meios adequados, com um posto consular ou com a missão diplomática do Estado de que seja nacional ou que, por outro motivo, esteja habilitada a receber a comunicação, à luz do direito internacional, ou com representante da organização internacional competente no caso de um refugiado ou de uma pessoa que, por qualquer motivo, encontre-se sob a proteção de uma organização intergovernamental.
} 
adotada pela Assembléia geral em sua resolução 40/144, de 13 de dezembro de $1985^{77}$.

RichARD PERRUCHOUd ${ }^{78}$ ressalta que a Convenção de Viena sobre Relações Consulares de 1963, enquanto não seja um tratado internacional de direitos humanos strictu sensu, contem provisões relevantes para a proteção dos direitos humanos. E que é fato que a Convenção Internacional sobre a Proteção dos Direitos de Todos os Trabalhadores Migrantes e dos Membros das suas Famílias é um tratado internacional de direitos humanos. Esses instrumentos conferem um número de direitos, tanto para os Estados como para os imigrantes: o direito de informação sobre proteção consular e assistência; o direito de notificação consular; o direito de comunicação consular.

Oportunamente exercida, a assistência consular é, portanto, situação real que ampara os estrangeiros que se encontram sujeitos a um procedimento penal, do qual dependem os seus bens jurídicos mais valiosos e, eventualmente, a sua própria vida, porque auxilia para que eles recebam tratamento justo e igualitário por parte dos tribunais locais e das autoridades penais do Estado Receptor. E tendo em vista as diferenças não apenas com relação à língua, mas também culturais, sociais, e jurídica, uma vez que cada país possui seu próprio sistema jurídico-criminal, o papel dos funcionários consulares torna-se essencial para assegurar os direitos e garantias fundamentais aos estrangeiros que forem presos, encarcerados, postos em prisão preventiva ou detidos de qualquer maneira no território do Estado Receptor, onde experimentam, muitas vezes, condição de particular vulnerabilidade.

A singularidade da atuação consular é a de quase sempre lidar diretamente com pessoas, de tratar de assuntos que podem afetar imediatamente suas vidas e seus relacionamentos, que muitas vezes envolvem vulnerabilidades econômico-sociais, com forte carga emocional e notável potencial de chegar aos

\footnotetext{
${ }^{77}$ Artigo 10: "Todo estrangeiro terá liberdade em qualquer momento para se comunicar com o consulado ou a missão diplomática do Estado de que seja nacional ou em sua falta, com o consulado ou a missão diplomática de qualquer outro estado que tenha sido confiado à proteção no estado em que resida dos interesses do que seja nacional".

78 Perruchoud, Richard. Consular protection and assistance. In: CHOLEWINSKI, Richard. International Migration Law: Developing Paradigms and Key Challenges, p. 78.
} 
parlamentos, aos órgãos de defesa dos direitos humanos e à mídia. Seu manejo é assim objeto de grande visibilidade, tanto em âmbito doméstico como externo. 
Parte II

Casuística internacional Relativamente a Violações Da CONVENÇão de Viena SOBRE RELAÇões CONSUlaRES dE 1963 


\section{Capítulo 3}

\section{INTRODUÇÃO À ESCOLHA DOS CASOS INTERNACIONAIS OBJETO DO PRESENTE ESTUDO}

Neste capítulo introdutório quanto à escolha dos casos internacionais que fundamentam o presente estudo dos efeitos no Direito brasileiro da casuística internacional sobre a violação do artigo 36 da Convenção de Viena sobre Relações Consulares de 1963, o propósito é fundamentar os motivos pelos quais se concentrou nas decisões da Corte Internacional de Justiça. É o principal órgão judicial das Nações Unidas, e o único tribunal internacional que tem competência geral para solucionar litígios entre todos os membros da Organização das Nações Unidas, praticamente todos os Estados do mundo. Possui uma importância considerável, política e acadêmica. Muitas das suas decisões solucionaram disputas internacionais reais. E, embora emalgumas situações, faltaram esforços de alguns Estados para o cumprimento de suas decisões, ou reconhececimento de sua jurisdição, continua a ser um símbolo poderoso para a possibilidade de um sistema jurídico internacional. ${ }^{79}$

De fato, um paralelo essencial é o estudo da Opinião Consultiva n. ${ }^{\circ}$ 16/99 emitida pela Corte Interamericana de Direitos Humanos, porque ambos os tribunais, cada qual limitando à sua competência e ponto de vista, traçaram interpretações sobre o direito à informação sobre a assistência consular para preso estrangeiro, como deve ser esse direito observado pelo Estado Receptor, e as conseqüências de sua violação perante o Estado que envia e perante o indivíduo. Cada tribunal oferece importantes lições, em mais de uma vertente, tanto para o

79 Posner, Eric A. e Figueiredo, Miguel de. Is the International Court of Justice Biased? University of Chicago. Law \& Economics, Olin Working Paper, Nr 234. December, 2004. The Chicago Working Paper Series Index: Disponível online em: < http /Lawecon/index.html://www.law.uchicago.edu>. Social Science Research and at the Network Electronic Paper Collection: Disponível online em:http://ssrn.com/abstract=642581>. 
Direito Internacional Público contemporâneo, quanto para o ordenamento jurídico interno dos Estados partes desse tratado, que representam um verdadeiro avanço na prática e respeito ao direito de notificação e informação sobre a assistência consular para preso estrangeiro.

A Corte Internacional de Justiça é o principal órgão judicial das Nações Unidas, segundo o artigo 92 da Carta das Nações Unidas. ${ }^{80}$ O Estatuto da Corte Internacional de Justiça, anexo à Carta das Nações Unidas, estabelece o enquadramento organizacional e os procedimentos que regem os casos julgados pela Corte Internacional de Justiça. O artigo 94.1 da Carta das Nações Unidas prevê o “princípio geral de Direito Internacional da natureza vinculante das decisões” de um tribunal internacional, "cada Membro das Nações Unidas se compromete a conformar-se com a decisão da Corte Internacional de Justiça em qualquer caso em que for parte". ${ }^{81}$ Porém, a submissão à jurisdição da Corte, "em qualquer caso", depende do consentimento das partes ${ }^{82}$. Assim, o artigo 36 do seu Estatuto delineia duas maneiras pelas quais uma nação pode aceitar a sua jurisdição: o consentimento pode ser geral, ou seja, a jurisdição para solução qualquer questão sobre interpretação e aplicação de um tratado ou do Direito Internacional Geral, cuja declaração deve ser remetida ao depósito ao Secretário Geral das Nações Unidas, para transmissão aos outros membros da comunidade internacional; ou o Estado pode

\footnotetext{
${ }^{80}$ ). Foi criada em junho de 1945, pela Carta das Nações Unidas, e iniciou seus trabalhos em abril de 1946. Sua sede é no Palácio da Paz na Haia (Países Baixos). Dos seis principais órgãos das Nações Unidas, é o único que não está localizado em Nova Iorque, Estados Unidos. O papel principal da Corte é resolver, de acordo com o Direito Internacional, disputas legais submetidas por Estados e dar pareceres consultivos sobre questões jurídicas submetidas por órgãos das Nações Unidas e agências especializadas. É composto de 15 juízes, que são eleitos para mandatos de nove anos pela Assembléia Geral da ONU e o Conselho de Segurança. É auxiliado por uma Secretaria, o seu órgão de administração. Suas línguas oficiais são o Inglês eo Francês.

${ }^{81}$ SCHulte, Constanze. Compliance with decisions of the International Court of Justice, p.29. Princípio confirmado pelos artigos 59 e 60 de seu Estatuto.

${ }^{82}$ Os Estados ainda estão relutantes em concordar com o julgamento de conflitos pela Corte ex ante, porque temem as importantes questões políticas que possam estar em jogo. Assim, poucos Estados consentiram com a cláusula facultativa da Corte, e não há tendência perceptível para uma maior aderência; daí há quem diga que é tentador considerar a jurisdição obrigatória da Corte como ilusória. Acredita-se que este é o indicador verdadeiro e um dos problemas mais profundos, para caracterizar a CIJ como estando em "declínio de longo prazo". Curiosamente, no entanto, a prática real desmente essa conclusão; as últimas décadas têm demonstrado que a jurisdição compulsória está longe de ser letra morta, porque a esmagadora maioria da pauta Corte foi iniciada através da invocação unilateral pela recorrente de jurisdição obrigatória, haja vista as cláusulas compromissórias nos próprios tratados em litígio. Llamzon, Aloysius P. Jurisdiction and Compliance in Recent Decisions of the International Court of Justice, pp. 817-818.
} 
aceitar especificamente a competência de uma categoria especial de casos ou conflitos nos termos de um tratado em separado. ${ }^{83}$

As provisões da executoriedade das decisões da Corte encontram-se mais na Carta das Nações Unidas que em seu Regulamento ou Estatuto. O Estado que recusa cumprir com boa-fé essas decisões pode accaretar tensões políticas, que não serão determinadas por outro exame judicial da Corte, mas por meio de ações políticas imediatas no âmbito do Conselho de Segurança da ONU, o órgão competente para a manutenção da a paz e a segurança (por meio de operações de paz; aplica;ao de sanções internacionais; autoriza;ao de interferências militares, na forma de Resoluções). Além disso, compete ao Conselho de Segurança assegurar o cumprimento das decisões da Corte Internacional de Justiça, conforme o artigo 94 (2) da Carta das Nações Unidas, que dispõe que "se uma das partes num caso deixar de cumprir as obrigações que lhe incumbem em virtude de sentença proferida pela Corte, a outra terá direito de recorrer ao Conselho de Segurança que poderá, se julgar necessário, fazer recomendações ou decidir sobre medidas a serem tomadas para o cumprimento da sentença." O não-cumprimento de uma decisão da Corte é uma violação de Direito Internacional suscetível a responsabilização, independente do objeto da disputa ou dos termos da sentença. ${ }^{84}$

CONSTANZE SCHUlte ${ }^{85}$ explica que as sentenças aplicam-se aos Estados de forma geral, e não sobre um órgão específico qualquer, embora quem represente o Estado perante à Corte seja mesmo o governo. O cumprimento da decisão uma questão de direito interno, que decide a partir de seu direito interno como cumprir, e não pode alegar um obstáculo de direito interno para escusar o descumprimento de uma decisão da Corte. O Direito Internacional não possui um

${ }^{83}$ Originalmente, os EUA consentiram com a jurisdição geral da Corte Internacional de Justiça em 1946, mas denunciaram-na em 1985. U. S. Dept. of State Letter and Statement Concerning Termination of Acceptance of ICJ Compulsory Jurisdiction (Oct. 7, 1985). "Secretary's Letter to UN Secretary General, Oct. 7, 1985 Dear Mr. Secretary-General: I have the honor on behalf of the Government of the United States of America to refer to the declaration of my Government of 26 August 1946, as modified by my note of 6 April 1984, concerning the acceptance by the United States of America of the compulsory jurisdiction of the International Court of Justice, and to state that the aforesaid declaration is hereby terminated, with effect six months from the date hereof. Sincerely Yours, George P. Shultz."

${ }^{84}$ SCHULTE, Constanze. Compliance with decisions of the International Court of Justice, p. 35.

${ }^{85}$ SCHULTE, Constanze. Compliance with decisions of the International Court of Justice, pp. 2426 e $29-30$. 
órgão para a execução da decisão, muito menos impõe um prazo para o cumprimento pelo Estado, que depende de circunstâncias concretas em cada caso, como a cooperação entre as partes litigantes. É o Estado, como sujeito de Direito Internacional determina como cumprir com a obrigação internacional e qual medida necessária deverá arcar para isso. A organização política interna do Estado, como quando Federado, não poderá servir como obstáculo ao cumprimento das decisões da Corte. Quando o Estado condenado reluta em cumprir com a decisão, pode ser chamado à Corte para interpretar o julgamento e facilitar negociações diplomáticas subseqüentes. ${ }^{86}$

Por ser o tribunal internacional de jurisdição geral, muitas vezes recebe questões a serem decididas com base no Direito Internacional Geral. Todos os outros tribunais internacionais recebem apenas os casos que surjam no âmbito do regime do tratado para a qual foram criados. Esse contexto limitado restringe a capacidade de servirem como fóruns definitivos sobre as questões de Direito Internacional Geral. Esse papel é, com efeito, reservado ao principal órgão judicial das Nações Unidas, que pode levar em conta a evolução do Direito Internacional em todo o espectro das relações internacionais. Seus julgamentos, ordens de medidas provisórias e pareceres consultivos, como resultado, refletem a perspectiva de um tribunal sem restrições por limitações estreitas que um regime especial pode impor a um fórum internacional. Assim, seus pronunciamentos sobre Direito Internacional Geral são necessariamente mais persuasivos do que declarações semelhantes feitas por tribunais internacionais com competência e perspectivas estreitas. Isto reforça o papel de liderança que a Corte Internacional de Justiça realiza na manutenção e desenvolvimento do Direito Internacional Geral.

\footnotetext{
${ }^{86}$ Em julho de 2009, a candidata ao título de Mestre em Direito Internacional teve a inesquecível experiência de cursar o curso de verão em Direito Internacional Privado da Academia de Direito Internacional da Haia, na Holanda, e aproveitou a oportunidade de conhecer e visitar o interior da Corte Internacional de Justiça, havendo inclusive presenciado ao vivo a leitura de uma sentença internacional referente ao caso Dispute regarding Navigational and Related Rights (Costa Rica v. Nicaragua), de 2005; visitou também a Corte Permanente de Arbitragem que, assim como a Corte Internacional de Justiça, situa-se no Palácio da Paz. Outro visitado foi o Tribunal Penal Internacional, havendo presenciado uma audiência de instrução com a presença física do acusado CHARLES TAYLOR, no caso do Tribunal Especial para Serra Leoa.
} 
O que limita a atuação da Corte Internacional de Justiça é a competência exclusiva para julgar questões envolvendo apenas Estados, conforme o artigo 34 de seu Estatuto. Daí, outros fóruns internacionais mais especializadas têm competência para abordar as reivindicações de entidades não-Estatais, direta e indiretamente. ${ }^{87}$ No campo dos Direitos Humanos e Direito Penal Internacional, a Corte limitou as oportunidades, sendo obrigada a ceder estas áreas para outros fóruns internacionais. Argumentos fortes em prol da expansão do tribunal judicial das Nações Unidas nessas áreas podem ser feitas. Por outro lado é difícil é o pronunciamento sobre Direito Internacional Geral pelos tribunais nacionais, que poderiam se beneficiar da experiência e da uniformidade que pode ser promovida pela análise da Corte. Enquanto teoricamente qualificados para pronunciar-se sobre o Direito Internacional, eis que tratados são incorporados ao direito interno, os juízes nacionais não têm a amplitude da experiência e da compreensão do Direito Internacional à disposição dos juízes da Corte. Uma cacofonia de pronunciamentos jurídicos internos decorrentes de circunstâncias várias poderiam se beneficiar das opiniões consultivas da Corte.

Uma das discussões mais atuais no seio da Comissão de Direito Internacional das Nações Unidas talvez seja a proliferação de tribunais internaiconais especializados, criados para atender o Direito Internacional Contemporâneo e suas especialidades. A discussão tem a ver com, se essa multiplicação prejudicaria, ou ameaçaria, a coerência e legitimidade do Direito Internacional Público ou, mais especificadamente, do sistema jurídico internaiconal, ou até mesmo causaria conflitos entre decisões. A Corte Internacional de Justiça, desde sua predecessora, Corte Permanente de Justiça Internacional, nunca atuou sozinha como o tribunal exclusivo para resolver as controvérsias em conformidade com o direito internacional. Tem sempre coexistido com outras instâncias terceiras ad hoc.

${ }^{87}$ O Centro Internacional para Arbitragem de Disputas sobre Investimentos (ICSID); a Convenção para a Solução de Disputas sobre Investimentos entre Estados e Nacionais de Outros Estados, que possibilita a arbitragem entre Estados e investidores privados; o Tribunal de Reclamações Irã-Estados Unidos, que deu acesso a muitas entidades não-Estatais à grandes reivindicações ao Tribunal para recuperar os seus créditos contra o Estado acusado de ter causado as suas perdas. "There are, however, reasons for caution here also. In the case of non-State entities, one must keep in mind that international law is primarily a system of law addressed to State Entities. The pressures on States to abide by authoritative international law are substantial, even in the decentralized legal system in which they operate." CHARNEY, Jonathan I. Is international law threatened by multiple international tribunals?, p. 366. 
Recentes desenvolvimentos no próprio Direito Internacional Público estão mudando o ambiente internacional como resultado da criação de instâncias internacionais permanentes. $^{88}$

Ainda sobre o tema da proliferação dos tribunais internacionais, questiona-se se uma hierarquia poderia ser estabelecida entre eles. CHARNEY ${ }^{89}$ ressalta que a comunidade internacional não vai e nem pode estabelecer essa hierarquia dos tribunais internacionais, para colocar a Corte Internacional de Justiça, ou qualquer outro tribunal internacional, no ápice do Direito Internacional, que atuaria como uma "Suprema Corte de Direito Internacional." Embora as razões podem ser muitas, duas são principais: (1) o fato de que um tratado universal, ou quase universal, de Estados para ungir qualquer fórum em particular com este status parece praticamente politicamente impossível; e (2) essa "Suprema Corte" prejudicaria o desejo da comunidade por diversos fóruns, e muitas das vantagens decorrentes dessa multiplicidade. Para $\mathrm{CHARNEY}^{90}$, a revisão por um tribunal de competência genérica poderia comprometer as características que tornam os diversos tribunais internacionais alternativas atraentes para solução de conflitos de matéria

\footnotetext{
${ }^{88}$ Na verdade, o fenômeno da "fragmentação" do Direito Internacional é arguido desde a década de 1850, como forma de questionar a composição e a legitimaidade do Direito Internacional. Mas a conotação negativa que o termo "fragmentação" carrega tem assegurado a sua utilização por aqueles que desejam desafiar a direção que o Direito Internacional está tomando. De fato, o termo "diversificação" ou até mesmo "desenvolvimento" pode ser usado para descrever o mesmo processo, e com conotação mais positiva."Desenvolvimento" parece implicar que há um objetivo sendo perseguido, que há um resultado que está sendo procurado; enquanto que a "fragmentação" implica que este resultado não está sendo procurado, e nem será alcançado. "Usually, fragmentation is used in a substantive manner, in other words, it is used to describe what is going on in the substance of international law. (...) It has been used to describe the institutional developments in international law. In this case, international law is fragmenting simply because of the proliferation of courts and tribunals, without necessarily perceiving this as a negative trend, or even as a threat to the substantive unity. If the different courts apply the same law, then there will be no substantive fragmentation as a result of institutional fragmentation." SCHELTEMA, Heko. The Fragmentation of International Law: Framing the Debate. European University Institute. February 20th, 2010, pp. 04 e 14-16. Disponível online em: <http://papers.ssrn.com/sol3/papers.cfm?abstract_id=1581425>, (acesso em: 01/10/2010).

${ }^{89}$ ChaRney, Jonathan I. The impact on the international legal system of the growth of international courts and tribunals. Materials and Publications. NYU Journal of International Law and Politics, Vol. 31, p. 698. Disponível online em: <http://www.pictpcti.org/publications/PICT_articles/JILP/Charney.pdf> (acesso em 29/09/2010).

${ }_{90}$ ChaRney, Jonathan I. The impact on the international legal system of the growth of international courts and tribunals. Materials and Publications. NYU Journal of International Law and Politics, Vol. 31, pp. 698-699. Disponível online em: <http://www.pictpcti.org/publications/PICT_articles/JILP/Charney.pdf> (acesso em 29/09/2010).
} 
específica. Assim, um número significativo de tribunais internacionais independentes continuará a ser uma realidade do sistema jurídico internacional no futuro.

Com base nas principais doutrinas de Direito Internacional Público, daí incluindo-se o Direito dos Tratados; as fontes do Direito Internacional; a Responsabilidade Internacional do Estado; a reparação por danos a estrangeiros; Esgotamento dos Recursos Internos; nacionalidade e o Direito Internacional de Fronteiras Marítimas, ele ${ }^{91}$ analisa a jurisprudência de diversos tribunais internacionais judiciais e administrativos. CHARNEY conclui que esses foros compartilham visões relativamente semelhantes de Direito Internacional Público Geral, e engajam-se na mesma dialética.

O aumento do número de tribunais internacionais, ausente um sistema hierárquico eficaz, que produzisse respostas definitivas às eventuais diferenças sobre interpretação das normas do Direito Internacional, significa que acompleta uniformidade das decisões é impossível. No entanto, CHARNEY $^{92}$ observa que a multiplicidade de tribunais internacionais permite um certo grau de experimentação e exploração, que pode levar a melhorias na legislação internacional, contribuindo com ideias que poderão ser incorporadas ao Direito Internacional Geral. Além disso, facilita a avaliação das idéias pela comunidade internacional como um todo. Até porque, em alguns casos, soluções únicas para circunstâncias especiais pode ser a melhor alternativa. Daí, uma estrutura muito hierárquicamente rígida para as decisões internacionais poderia colocar restrições indesejáveis para o próprio desenvolvimento do Direito Internacional Geral e da advocacia especializada em áreas específicas.

\footnotetext{
91 "The fundamentals of this general international law remain the same regardless of which tribunal decides the case". ChARNEY, Jonathan I. The impact on the international legal system of the growth of international courts and tribunals. Materials and Publications. NYU Journal of International Law and Politics, Vol. 31, pp. 698-699. Disponível online em: <http://www.pictpcti.org/pub lications/PICT_articles/JILP/Charney.pdf> (acesso em 29/09/2010).

92 CHARNey, Jonathan I. The impact on the international legal system of the growth of international courts and tribunals. Materials and Publications. NYU Journal of International Law and Politics, Vol. 31, p. $700 . \quad$ Disponível online em: <http://www.pictpcti.org/publications/PICT_articles/JILP/Charney.pdf> (acesso em 29/09/2010).
} 
Também é difícil argumentar que a multiplicação de tribunais internacionais têm causado distanciamento do órgão judicial das Nações Unidas, negando-se, assim, o seu legítimo prestígio. Também não parece provável que um "declínio" da Corte esteja no horizonteem vez disso, nos últimos anos, a Corte tem recebido o maior número de casos na sua história, embora o aparente pequeno número de casos julgados, e tem agilizado os seus procedimentos, a fim de lidar com mais casos. O cronograma para apresentação de memoriais, contra-memoriais e outros documentos, é normalmente longo, e fixado especialmente para cada caso. Não há limites para apresentação de documentos. As audiências podem levar muitas semanas, e os processos internos de tomada de decisão e elaboração de sentenças é um trabalho intensivo para todos os juízes, e consome um tempo considerável. Além disso, as opiniões concordantes e divergentes podem ser de enorme extensão. Os próprios Estados desejam que os casos em que litigam sejam cuidadosamente julgados.

CHARNEY $^{93}$ salienta que essa demora não quer dizer que a Corte Internacional de Justiça não seja capaz de atuar de forma mais célere, conforme necessário, ou que os seus procedimentos em geral não possam ser melhorados. Ele cita, por exemplo, o Caso BREARD, um dos casos objeto de nosso estudo, quando a Corte agiu rapidamente para ordenar uma medida provisórias de proteção, demonstrando a delicadeza da sua autoridade, instruindo os Estados Unidos a tomar todas as medidas ao seu alcance para impedir a execução do SR. FRANCISCO BREARD pelo estado da Virgínia.

Na verdade, a Corte Internacional de Justiça tem tomado medidas para melhorar os seus procedimentos, mas a comunidade internacional tem também implicitamente resistido a esse reforço. ${ }^{94}$ Isso pode refletir o fato de que outros

\footnotetext{
93 ChARnEY, Jonathan I. The impact on the international legal system of the growth of international courts and tribunals. Materials and Publications. NYU Journal of International Law and Politics, Vol. 31, p. 702. Disponível online em: <http://www.pictpcti.org/publications/PICT_articles/JILP/Charney.pdf> (acesso em 29/09/2010).

${ }_{94}$ Por exemplo, como medidas para aumentar a eficácia dos seus procedimentos internos, instou os Estados em litígio a apresentarem articulados mais claros, sucintos, e fez suas ordens e decisões rápida e facilmente acessível a todos em seu site. O então Presidente da Corte Internacional de Justiça, lamentou publicamente o declínio do orçamento destinado pela ONU à Corte, de U\$ 11 milhões anuais, embora o número de casos aumente cada vez mais: "While the caseload of the Court has
} 
fóruns internacionais serem complementos necessários, especialmente em questões que envolvem temas específicos, ou de menor preocupação central do Estado, ou ainda, que envolvam partes incompetentes para litigarem perante a Corte. $\mathrm{O}$ fato de que apenas os Estados podem ser Partes perante a ela pode explicar a criação de outros tribunais.

Os advogados envolvidos em litígios internacionais geralmente conhecem a posição de outros tribunais, principalmente os da Corte Internacional de Justiça, que acabam sempre sendo alegadas perante outros fóruns, quando surge um problema jurídico surge. Assim, um significativo número daquilo que CHARNEY chama de "fertilização cruzada" ocorre entre os tribunais internacionais. Neste ambiente, a Corte continua sendo uma força prodigiosa. As suas decisões e opiniões consultivas continuam a ser os mais analisados e mais frequentemente referenciados em decisões de outros tribunais que abordam sobretudo questões de Direito Iternacional Geral. Isso é improvável que mude em um futuro previsível, tendo em vista a sua competência geral. ${ }^{95}$ Assim, outros fóruns internacionais complementam o trabalho da Corte e fortalecem o sistema de Direito Internacional, não obstante o risco de alguma perda de uniformidade. A própria comunidade internacional está predisposta a levar a sério os pontos de vista da Corte Internacional de Justiça sobre o Direito Internacional Geral, campo em que continuará a ter influência, que está muito além de sua jurisdição nominal. E isso é verdade, muito embora nao tenha sido dotada pela comunidade internacional com o status de "Suprema Corte de Direito Internacional", com autoridade universal de revisão. Mesmo assim a Corte tem um

significantly increased, it has not enjoyed a proportional growth in its resources... Today its total budget is of the order of \$11,000,000 a year, a smaller percentage of the budget of the Organization than in 1946. This has resulted in an enlarging gap between the conclusion of the written, and the opening of the oral, phase of a case, a gap caused by the backlog in the work of the Court." A título de comparação, apenas para o TPI para ex Iugoslávia, foram destinados U\$ 70 milhões. International Court of Justice must be afforded the resources to work with full effectiveness and dispatch, President Schwebel tells United Nations General Assembly. Press Release, October 27 ${ }^{\text {th }}, 1998$ Disponível online em: <http:/www.icj-Corte Internacional de Justiça.org/presscom/index.php?pr=619\&pt=1\&p1=6\&p2=1\&PHPSESSID=5c407> (acesso em 30/09/2010).

95 CHARNEY, Jonathan I. The impact on the international legal system of the growth of international courts and tribunals. Materials and Publications. NYU Journal of International Law and Politics, Vol. 31, p. 705 . Disponível online em: <http://www.pictpcti.org/publications/PICT_articles/JILP/Charney.pdf> (acesso em 29/09/2010). 
papel importante a desempenhar na manutenção da coerência da interpretação do Direito Internacional Geral - uma função valiosa. ${ }^{96}$

Todos os outros tribunais internacionais permanentes têm competência limitada ao âmbito do regime dos tratados que os instituíram. Este contexto limitado e perspectiva reduzida, restringe a capacidade desses de servirem como fóruns definitivos para as questões de Direito Internacional Geral. Esse papel é, de fato, reservado para a Corte Internacional de Justiça, com pronunciamentos persuasivos, o que reforça o papel de liderança que realiza na manutenção da coerência e desenvolvimento do Direito Internacional Geral. ${ }^{97}$

Se um sistema judicial hierárquico de direito internacional não há de ser estabelecido. E para que se possa evitar o conflito de interpretações por esses diversos tribunais internacionais especializados, o que CHARNEY chama de "forças centrífugas", dois fatores funcionariam como "contra-forças". Todos os participantes do sistema internacional devem ser sensíveis aos riscos inerentes a um sistema descentralizado e horizontal, e ter cuidado para evitar ações que possam enfraquecêlo. Em primeiro lugar, a Corte deverá manter seu papel de liderança intelectual na área. Segundo, outros tribunais devem ser incentivados a aumentar o diálogo que já existe com o tribunal das Nações Unidas - é o que ele chama de "diálogo das fontes" - a idéia de que todos esses tribunais estão engajados em um esforço comum, podendo a Corte das Nações Unidas, em suas decisões, considerar teorias usadas por esses tribunais, sem perder sua liderança, o que consagraria ainda mais seu respeito, e a própria manutenção de um grau de coerência do próprio sistema jurídico internacional pacífico e benéfico, para todos os participantes. Isso poderia

\footnotetext{
${ }^{96}$ ChARney, Jonathan I. The impact on the international legal system of the growth of international courts and tribunals. Materials and Publications. NYU Journal of International Law and Politics, Vol. 31, p. 705. Disponível online em: <http://www.pictpcti.org/publications/PICT_articles/JILP/Charney.pdf> (acesso em 29/09/2010).

96 CHARNEY, Jonathan I. The impact on the international legal system of the growth of international courts and tribunals. Materials and Publications. NYU Journal of International Law and Politics, Vol. 31, p. 702. Disponível online em: <http://www.pictpcti.org/publications/PICT_articles/JILP/Charney.pdf> (acesso em 29/09/2010).

97 CHARNeY, Jonathan I. The impact on the international legal system of the growth of international courts and tribunals. Materials and Publications. NYU Journal of International Law and Politics, Vol. 31, p. 706. Disponível online em: <http://www.pictpcti.org/publications/PICT_articles/JILP/Charney.pdf> (acesso em 30/10/2010).
} 
proporcionar fortes pressões contra as "forças centrífugas", ao mesmo tempo permitindo a independência destes tribunais especializados. ${ }^{98}$

No futuro, sem dúvidas que a Corte Internacional de Justiça, desempenhará um papel cada vez mais importante. HANS CORELL sustenta que a influência dos tribunais em qualquer sistema ultrapassa os casos julgados. É bem verdade que o artigo 59 do Estatuto da Corte Internacional de Justiça prescreve que as decisões da Corte não têm força vinculante, exceto entre as partes no caso e com relação ao litígio em questão. Todavia, por razões óbvias os Estados observam a sua jurisprudência e desenham suas próprias conclusões. Assim, essa jurisprudência é de grande assistência aos Estados quando buscam resolver controvérsias entre outros Estados sem recorrer a um terceiro. ${ }^{99}$

É por conta desse prestígio e papel de liderança que se optou por concentrar o presente estudo na casuística da Corte Internacional de Justiça. Com relação às decisões dos casos objeto do presente estudo, tanto as medidas provisórias quanto às sentenças de mérito, a Corte tem a oportunidade histórica para esclarecer e regulamentar a forma como o direito de informação e notificação sobre a assistência consular para o preso estrangeiro deve ser obedecido pelo Estado Receptor, tanto perante o Estado que envia, mas, principalmente, quanto ao indivíduo em situação de privação de liberdade.

Paulo Borba Casella avalia as decisões Avena e LaGrand a partir do fato de existirem direitos fundamentais assegurados não apenas por constituições e sistemas nacionais, mas por meio de tratados, que se tornam parte integrante do conjunto de garantias de direitos fundamentais e podem ter sua implementação feita também pela Corte Internacional de Justiça. Assim, esse tribunal internacional, tradicionalmente competente para julgar questões entre Estados, nesses casos, atua como instância de controle e implementação ide direitos

98 CHARNEY, Jonathan I. The impact on the international legal system of the growth of international courts and tribunals. Materials and Publications. NYU Journal of International Law and Politics, Vol. 31, p. 707. Disponível online em: <http://www.pictpcti.org/publications/PICT_articles/JILP/Charney.pdf> (acesso em 30/10/2010).

${ }^{99}$ Corell, Hans. The Role of Public International Law and the ICJ in a Changing World, pp. 17 18. 
fundamentais, em relação a Estados que estariam cometendo violações de direitos fundamentais garantidos por tratados, que constituíam obrigações para esse Estado, em âmbito de direito processual penal interno, no sentido de assegurar sua observação por seus tribunais e pela administração nacional, sob pena de ser responsabilizado internacionalmente. Ou seja, a Corte, muito embora mantenha a condição de tribunal internacional para julgar controvérsias entre Estados, aqui se apresenta como instância de controle e averiguação de aplicação do Direito Internacional pelos Estados. Isso porque, a matéria regulada no plano internacional, cria para o Estado a obrigação de observar e aplicar os dispositivos do tratado internacional em que é parte, no presente caso, a Convenção de Viena sobre Relações Consulares, enquanto assinado e ratificado pelo Estado, não obstante a competência do Estado para regular internamente o funcionamento dos tribunais e da organização do judiciário nacional. ${ }^{100}$

No julgamento sobre o caso dos Reféns em Teerã (Estados Unidos vs. Irã), a Corte Internacional de Justiça alertou que as obrigações em questão não são meramente obrigações contratuais, no caso estabelecidas pelas Convenções de Viena sobre Relações Diplomáticas e Consulares, respectivamente de 1961 e 1963, mas também obrigações estabelecidas sob o manto do direito internacional geral. E que privar de forma abusiva seres humanos de sua liberdade e submetê-los a constrangimento físico em condições de sofrimento em si é manifestamente incompatível com os princípios da Carta das Nações Unidas, bem como com os princípios fundamentais enunciados na Declaração Universal dos Direitos do Homem. Mas o que deve ser ressaltado é a extensão e gravidade do conflito entre a conduta do Estado iraniano e as suas obrigações no âmbito de todo o corpo de regras internacionais em que as missões diplomáticas e consulares é composto. ${ }^{101}$

É por essas razões que CANÇADO TRINDADE explica que a Corte Internacional de Justiça estabeleceu a relevância dos princípios de Direito Internacional geral, assim como de Direito Internacional de Direitos Humanos. Para

\footnotetext{
${ }^{100}$ Casella, Paulo Borba. Fundamentos do Direito Internacional Pós-Moderno, pp. 1258 e 1259.

${ }^{101}$ International Court of Justice. United States Diplomatic and Consular Staff in Tehran (United States of America v. Iran). Case concerning U.S. Diplomatic and Consular Law in Tehran. Sentença (1980), p. 42, parágrafo 91. Disponível online em:< http://www.icj-Corte Internacional de Justiça.org/docket/files/64/6291.pdf> (acesso em 08/09/2009).
} 
ele, o corpus iuris do direito diplomático estava, então, abordado à luz de considerações básicas de humanidade. A Corte judicial das Nações Unidas, na mesma decisão, também chamou atenção de toda comunidade internacional para a universalidade do direito consular e diplomático codificado, cuja observância seria para beneficiar, no fim das contas, a humanidade como um todo. A decisão alerta à "consciência" da comunidade internacional, e não apenas aos seus atos de vontade. Daí porque um domínio do Direito Internacional que há algumas décadas fora concebido sobre uma base estritamente inter-Estatal, como o direito diplomático e consular, seja hoje permeado com conceitos básicos de humanidade. ${ }^{102}$

Por fim, mostra-se coerente a posição de JONATHAN CHARNEY ${ }^{103}$, de que ao invés de promover uma hierarquia no sistema jurídico internacional, seria melhor contar com a otimização da Corte Internacional de Justiça no uso da força da sua reputação histórica, financeira e intelectual que detém, bem como os esforços de todos os tribunais internacionais que abordam questões jurídicas para reconhecer seu interesse comum e a empenhar-se em um maior diálogo inter-tribunais. Estas são as chaves para a coerência do direito internacional permanecer como sendo praticada por esses tribunais. É também a maneira em que a ela pode continuar a servir o órgão internacional principal e mais influente, prestígio que perdura desde a criação da sua predecessora, e que não parece estar ameaçada pela existência de outros tribunais especializados para decidir os litígios que envolvam o Direito Internacional. Passa-se a partir do capítulo seguinte para o estudo da principal casuística internacional sobre a violação do artigo 36 da Convenção de Viena sobre Relações Consulares de 1963, e seus fundamentos sobre Direito Internacional clássico, e a partir de uma interpretação contemporânea, seus efeitos sobre o direito interno dos Estados, inclusive daqueles que, embora partes da Convenção, como no caso o Brasil, não participaram dos casos contenciosos internacional.

\footnotetext{
102 CANÇADO TRINDADE, Antônio Augusto. The Humanization of Consular Law: The Impact of Advisory Opinion No. 16 (1999) of the Inter-American Court of Human Rights on International CaseLaw and Practice, pp. 04 e 05.

${ }^{103}$ CHARNEY, Jonathan I. Is international law threatened by multiple international tribunals?, p. 373.
} 


\section{Capítulo 4}

Corte Internacional de Justiça - Caso Breard: Paraguai va. Estados Unidos da AmÉrica, APRESEnTAdo EM 03 DE ABRIL DE 1998, (Vienna Convention on Consular Relations - Paraguay V. UNITED STATES OF AMERICA)

ANGEL FRANSCISCO BREARD, paraguaio, foi preso em 01 de setembro de 1992 pelas autoridades do estado da Virginia, Estados Unidos da América, por suspeita de tentativa de estupro e assassinato de RUTH DiCKIE. Em seguida, foi julgado em 24 de junho de 1993, e condenado à pena de morte em 22 de agosto de 1993, sem jamais ter sido avisado sobre seu direito de receber assistência consular, e sem ter sido o Consulado paraguaio notificado pelas autoridades americanas sobre sua prisão. No julgamento do paraguaio, a promotoria apresentou provas potenciais da sua culpabilidade do paraguaio. Além do mais, ele confessou ser culpado pelo crime. Sua execução foi agendada para o dia 14 de abril de 1998, às 21 horas. Em nenhum momento do processo ele foi informado do direito à comunicação com o posto consular de sua nacionalidade e de receber a assistência pelos representantes consulares, conforme previsto pelo artigo 36 da Convenção de Viena sobre Relações Consulares, de 1963.

O Paraguai tomou conhecimento da prisão de seu nacional somente em meados de 1996, quando começou a assisti-lo em série de recursos e habeas corpus nos tribunais estaduais e federais, alegando a violação da referida Convenção. Foi a primeira vez que Breard alegou, desde o julgamento em 1993, que as autoridades americanas em nenhum momento o informaram, como cidadão paraguaio, de que teria o direito de contatar o consulado do Paraguai. A Corte 
Distrital rejeitou o habeas corpus por conta da doutrina de direito interno conhecida como procedural default doctrine, concluindo que ele deveria ter alegado essa violação na instância estadual, e que tampouco havia mostrado "causa ou prejuízo". O United States Court of Appeals confirmou. ${ }^{104}$ Daí o apelo foi para a Suprema Corte, por writ of certionari (em pouquíssimas palavras, um mandado emitido por um tribunal superior para um de jurisdição inferior exigindo o registro de um caso particular), e sem sucesso, pelo mesmo motivo.

\subsection{A apresentação da controvérsia perante a Corte Internacional de Justiça}

O Paraguai apresentou pedido de abertura de procedimento contencioso perante a Corte Internacional de Justiça em 03 de abril de 1998, contra os Estados Unidos da América, no seu próprio direito e no direito de exercer a proteção diplomática ${ }^{105}$ de seu nacional, haja vista a violação da Convenção de Viena de $1963 .{ }^{106}$ Pediu a restauração da situação anterior à violação da Convenção de Viena de 1963 pelo estado da Virginia, descrito como restitutio in integrum, e que os Estados Unidos estariam obrigados a garantir que qualquer detenção futura ou procedimento penal contra o Sr. BREARD ou quaisquer outros paraguaios no seu território, deveriam ser efetuadas em conformidade com as disposições legais internacionais aderidas pelos Estados Unidos, o que não deixaria de ser um pedido de

\footnotetext{
${ }^{104}$ (Breard v. Netherland, 949 F. Supp. 1255 (E.D. Va. 1996) e (Breard v. Pruett, 134 F. 3d 615, 620 (4th Cir. 1998).

${ }^{105}$ Trata-se de instituto pertencente ao domínio da responsabilidade internacional, quando o Estado vítima do ilícito internacional imputável a outra soberania não pretende ver-se ressarcido por dano causado diretamente à sua dignidade ou ao seu patrimônio, mas por alegada afronta ao patrimônio privado de um nacional seu. O objetivo é o particular - indivíduo ou empresa - que, no exterior, seja vítima de um procedimento estatal arbitrário, e que em desigualdade de condições frente ao governo estrangeiro responsável pelo ilícito que lhe causou dano, pede ao seu Estado de origem que o defenda, fazendo da reclamação uma demanda autêntica entre personalidades de Direito Internacional Público. O Estado é livre para conceder o endosso (outorga da proteção diplomática de um Estado a um particular), depois de verificar o esgotamento dos recursos internos acessíveis ao particular no território do Estado reclamado, ou recusá-lo. REzeK, Francisco. Direito Internacional. Curso Elementar, pp. 288-295.

${ }^{106}$ Tanto a República do Paraguai quanto os Estados Unidos são partes da Convenção de Viena e de seu Protocolo Facultativo relativo à solução compulsória de controvérsias. O artigo I do Protocolo Facultativo prevê que: "Os litígios decorrentes da interpretação ou aplicação da Convenção de Viena sobre Relações Consulares deve situar-se dentro da jurisdição obrigatória da Corte Internacional de Justiça, podendo, portanto, ser interposta perante a Corte por um pedido feito por qualquer das partes em litígio, sendo parte do presente Protocolo."
} 
garantia de não repetição. O Paraguai alegou que a falta da notificação ao consulado, sobre a detenção do Sr. BREARD, impediu que os representantes consulares providenciassem representação jurídica adequada para a defesa de seu nacional, já que ele foi representado por advogado dativo, não familiarizado com a cultura paraguaia e com o sistema de justiça criminal que um paraguaio esperaria encarar. ${ }^{107}$

Basicamente, entre outras coisas, o Paraguai alegou que, com a assistência consular oportuna, poderia ter contatado seu nacional, ajudado na sua defesa, monitorado as condições da sua detenção e garantido que as normas internacionais fossem respeitadas no tratamento e nos processos contra seu nacional. E que, como resultado da falta de assistência consular, o Sr. Breard teria feito uma série de decisões objetivamente ilógicas durante o processo penal instaurado contra ele, que era, inclusive, conduzido sem tradução. Ele se recusou a aceitar a oferta das autoridades por prisão perpétua ao invés da capital caso confessasse em oportunidade anterior ao julgamento. Em vez disso, o paraguaio insistiu em arriscar uma sentença de morte, ao preferir confessar e relatar o seu comportamento criminal passado, durante o julgamento.

Para o Paraguai, ele teria tomado essas medidas altamente prejudiciais porque - na ausência de recomendações do seu consulado - ele não compreendeu as diferenças fundamentais entre os sistemas de justiça penal dos Estados Unidos e do Paraguai. Eis que o Sr. Breard acreditava que sua confissão resultaria na misericórdia do Juiz americano, como ele entendeu que seria se estivesse enfrentando um procedimento criminal no Paraguai. $\mathrm{Na}$ realidade, estes atos praticamente asseguraram a sua condenação e sentença de morte.

Com efeito, a assistência consular oportuna teria incluído o aconselhamento sobre as diferenças culturais e jurídicas entre Paraguai e Estados Unidos, incluindo a oportunidade de aceitar ou rejeitar as "ofertas" da acusação (possibilidade de se negociar a pena - o "plea bargaining”) à luz dessas diferenças, a

\footnotetext{
${ }^{107}$ As alegações aqui relatadas foram todas extraídas do próprio de abertura de procedimento contencioso apresentado pelo Paraguai perante a CORTE INTERNACIONAL DE JUSTIÇA. Vienna Convention on Consular Relations (Paraguay $v$. United States of America), Application of The Republic Of Paraguay, April $3^{\text {rd }} 1998$.
} 
nomeação de um intérprete; um conselheiro jurídico complementar, na identificação e comunicação com os membros da família dele, que poderiam prestar assistência e informações à Defesa, fornecendo registros, documentos e outros elementos úteis, além de financiar o transporte de familiares e outras testemunhas para o estado da Virgínia, para prestarem depoimentos; coletar e apresentar provas favoráveis na a fase de sentença, e outras formas de assistência jurídica ou não. O Paraguai asseverou que essa assistência consular teria afetado o resultado do processo criminal contra o Sr. Breard, incluindo qualquer pena imposta.

\subsection{A medida provisória solicitada pelo Paraguai e ordenada pela Corte Internacional de Justiça}

Na mesma ocasião, alegando a "importância e santidade da vida humana individual, reconhecida pelo direito internacional", como pelo artigo $6^{\circ}$ do Pacto Internacional sobre Direitos Civis e Políticos, apresentou pedido urgente de medida provisória, buscando o restabelecimento do stauts quo ante, ou seja, da situação que existia antes da violação de direito internacional cometida pelos Estados Unidos, ao não providenciar a notificação do Posto Consular paraguaio e nem informar BREARD sobre esse direito, nos termos do artigo 36 da Convenção de Viena sobre Relações Consulares de 1963. O intuito era fazer com que os Estados Unidos tomassem todas as medidas necessárias à sua disposição para evitar a execução de BREARD, contrária ao direito internacional, marcada em 25 de fevereiro 1998, pelo Circuit Court of Arlington County, Virgínia, para o dia 14 de abril de 1998, até que a Corte Internacional de Justiça decidisse sobre o mérito do caso. ${ }^{108}$

\footnotetext{
${ }^{108}$ O Cônsul Geral do Paraguai também entrou com ação alegando a violação de seus direitos sob a Convenção de Viena de 1963. É que a 42 U.S.C § 1983 autoriza Embaixadores e Cônsules a terem causa de ação pela violação de tratado internaiconal, no caso o Paraguay-US Treaty of Friendship, Commerce and Navigation, se alegarem seus direitos, ou do País, que devem ser diferentes dos direitos já decididos pela Corte (aqui, seus direitos eram diferentes dos direitos de Breard). A Corte Distrital não admitiu a ação por falta de competência, alegando que não era o caso de violação continuada de lei federal.
} 
Em 09 de abril de 1998, a Corte Internacional de Justiça ordenou a medida, porque o caso não dizia respeito diretamente à administração da justiça criminal dos Estados Unidos, mas sim à violação de tratado internacional. O alcance e extensão dessa medida limitou-se: a) à prevenção da execução de ANGEL FRANCISCO BREARD, estando pendente a decisão de mérito da Corte sobre o procedimento; e b) à obrigação de os Estados Unidos informarem a Corte sobre as medidas tomadas para implementar a ordem. A particularidade é a clareza da parte operativa da ordem, referindo-se diretamente ao indivíduo, com a obrigação de uma ação específica - a suspensão da execução estando pendente a decisão final sobre o procedimento. ${ }^{109}$ A adequação da execução da medida não foi deixada à mercê dos Estados Unidos; de forma sábia, não adentrou no sistema criminal interno norte americano, porque ordenou apenas a suspensão da execução, e não se referiu à pena em si, focando apenas na questão de direito internacional. ${ }^{110}$

E quanto mais precisa for a ordem, mais precisa ainda deverá ser o contra-argumento para não implementá-la. E os Estados Unidos responderam de forma a tornar a questão mais geral, com base nas especificidades do seu sistema judicial interno, argumentando que o órgão judicial das Nações Unidas não teria prima facie jurisdição para ordenar medidas provisórias no caso, o que seria uma interferência no ordenamento jurídico independente dos estados; a possibilidade de a Corte se tornar um tribunal internacional de recursos criminais; e que bastaria um pedido formal de desculpas.

Em 13 de abril de 1999, a Secretária de Estado MAdELAINE K. ALBRIGHT, embora afirmando o caráter não-vinculante da medida provisória ordenada pela Corte, escreveu para o governador do estado da Virginia, JAMES S. GILMORE, solicitando a sustação da execução do paraguaio, porque isso poderia ser

\footnotetext{
${ }^{109}$ The Court, unanimously: 1. Indicates the following provisional measures: The United States should take all measures at its disposal to ensure that Angel Francisco Breard is not executed pending the final decision in these proceedings, and should inform the Court of all the measures which it has taken in implementation of this Order. Reports of judgments, advisory opinions and orders. Case concerning the Vienna Convention on Consular Relations. (Paraguay v. United States of America). Request for the indication of provisional measures.

Order of 9 April 1998, par. 41, p. 258.

${ }^{110}$ SHEIK, MANI. From Breard to Medellin: Supreme Court Inaction or ICJ Activism in the Field of International Law?, pp. 44-45.
} 
visto como se o país negasse significado ao direito internacional e à posição da Corte Internacional de Justiça nas relações internacionais, o que poderia resultar na limitação da habilidade para assegurar que americanos fossem protegidos no exterior. ${ }^{111}$

O Departamento de Justiça e Estado dos Estados Unidos informaram à Suprema Corte que medidas provisórias ordenadas pela Corte Internacional de Justiça não teriam força vinculante nos tribunais internos do País. No dia seguinte ao pedido, em 14 de abril de 1998, a Suprema Corte indeferiu o pedido de writ of certionari interposto pelo Paraguai, buscando a implementação da medida provisória, para suspensão da execução de Breard até a decisão de mérito pela Corte Internacional de Justiça sobre o caso.

A Suprema Corte, nesse julgamento, não se apoiou per se na violação do artigo 36 da Convenção de Viena sobre Relações Consulares de 1963, mas negou o pedido de habeas corpus do paraguaio com fundamento na doutrina federalista, de que a Corte não teria jurisdição para interferir no sistema jurídico-criminal interno. Além disso, baseou a decisão na doutrina processual interna chamada "doctrine of procedural default ${ }^{12}$ ", baseada na lei Antiterrorism and Effective Death Penalty $A c t^{113}$, porque a alegação de violação do artigo 36 da Convenção não poderia ter sido alegada em habeas corpus na instância federal porque não havia sido alegada na instância inferior, estadual (algo pareciso ao nosso prequestionamento). Tampouco seria um caso de exceção à $\mathrm{XI}^{\mathrm{a}}$ Emenda da Constituição americana, que estabelece

\footnotetext{
${ }^{111}$ Não surpreendentemente, o governador GILMORE recusou a concessão de indulto ou a suspensão da execução. Ele ressaltou que as preocupações da secretária ALBRIGHT eram de "grande devido respeito" e "séria consideração". Mas o mais importante para ele era o seu dever de garantir que os virginianos pudessem "conduzir a sua vida livre do medo do crime". Governador GILMORE também reconheceu que ele havia considerado demais o Departamento de Justiça, sugerindo que a CORTE INTERNACIONAL DE JUSTIÇA "não tem autoridade para interferir em nosso sistema de justiça criminal". SHEIK, MANI. From Breard to Medellin: Supreme Court Inaction or ICJ Activism in the Field of International Law?, p. 540.

${ }^{112}$ Por não fazer valer a sua reivindicação de violação da Convenção de Viena de 1963 em instância estadual, Breard não pôde exercer os seus direitos dispostos nesse tratado, haja vista as leis dos Estados Unidos e da Comunidade de Virgínia. Tendo falhado a fazê-lo, ele não pode levantar uma alegação de violação desses direitos agora em revisão de habeas em instância federal. Breard v. Greene, 523, 371, U.S., (14/04/1998), Supreme Court of the United States.

${ }^{113}(. .$.$) which provides that a habeas petitioner alleging that he is held in violation of "treaties of the$ United States" will, as a general rule, not be afforded an evidentiary hearing if he "has failed to develop the factual basis of [the] claim in State court proceedings.” 28 U.S. C. A. \$\$ 2254(a), (e)(2) (Supp. 1998). Breard v. Greene, 523, 371, U.S, (14/04/1998) Supreme Court of the United States.
} 
que "o poder judiciário dos Estados Unidos não deve ser interpretado no sentido de estender a qualquer ação de direito ou de equidade, iniciada ou processada contra um dos Estados Unidos, por cidadãos de outro, ou por cidadãos ou súditos de qualquer Estado estrangeiro. ${ }^{114}$

\section{A Suprema Corte salientou que em nada teria adiantado para o} paraguaio a assistência do seu consulado, porque ele fez questão de depor no julgamento, ao contrário do que seus advogados haviam indicado, deixando de ser beneficiado com a "plea bargain", o que lhe renderia ao menos a pena perpétua. ${ }^{115}$

114 Ratificada em 1795, a Emenda XI foi elaborada para anular a decisão da Suprema Corte em Chisholm v. Georgia, 2 E.U. (2 Dall.) 419, 1 L. Ed. 440 (1793), que considerou que um cidadão de um estado poderia processar o governo de outro Estado na Suprema Corte. Chisholm criou um redemoinho nos Estados Unidos. No fim da Revolução Americana, cada estado adquiriu grande dívida com credores estrangeiros para a assistência financeira e outros pagamentos recebidos durante a guerra. Representantes do Congresso temiam que Chisholm permitisse esses credores estrangeiros de pedir à justiça federal forçasse os cofres do Estado fiscalmente, a suportar os encargos destas dívidas. O texto da Emenda XI limita o poder dos tribunais federais para receber os processos contra os governos estaduais trazidos pelos cidadãos de outro Estado ou os cidadãos de um país estrangeiro. A Suprema Corte também tem interpretado a Emenda XI no sentido de barrar os tribunais federais das ações instituídas por cidadãos de um Estado sendo processado, e ações judiciais iniciadas pelos governos de países estrangeiros. Por exemplo, o estado de Nova York poderia invocar a Emenda XI para se proteger de ser processado no tribunal federal por seus próprios residentes, os residentes de outro Estado, os residentes de um país estrangeiro, ou o governo de um país estrangeiro. Está enraizada no conceito de FEDERALISMO, segundo o qual a Constituição cuidadosamente enumera os poderes do Congresso para governar a nível nacional, salvaguardando o poder dos estados para governar localmente. Ao limitar o poder dos tribunais federais para ouvir ações judiciais impetradas contra os governos estaduais, a Emenda XI tenta encontrar um equilíbrio entre a soberania partilhada pelos governos estadual e federal. No entanto, a Emenda XI não impede todas as ações judiciais impetradas contra os governos estaduais em tribunal federal. Quatro grandes exceções foram reconhecidas pela Suprema Corte. Em primeiro lugar, a Emenda XI não se aplica às ações judiciais movidas contra as subdivisões políticas de um estado. Assim, países, estados, cidades e municipalidades podem ser processados em um tribunal federal sem levar em conta as restrições da Emenda XI. A segunda exceção à aplicação da Emenda XI permite que um governo estadual renuncie à sua proteção constitucional ao concordar com uma ação contra esse num tribunal federal. A terceira exceção permite o Congresso revogue a imunidade de um estado de ser processado em um tribunal federal, por meio da aplicação da legislação em conformidade com os seus poderes de execução no âmbito da "proteção igual e das cláusulas de Devido Processo", da Décima Quarta Emenda. A exceção final da XI Emenda permite aos cidadãos de qualquer estado, a buscar uma "injunção" contra funcionários do estado, em um tribunal federal para "acabar com uma violação continuada do direito federal", como contra o governador. Disponível online em: <http://legaldictionary.thefreedictionary.com/Eleventh+Amendment> (acesso em 22/02/2010).

$115 \mathrm{O}$ professor JACOB DOLINGER critica o argumento da Suprema Corte americana de que a assistência do consulado paraguaio não modificaria em nada o resultado do julgamento, o para ele significa o "desconhecimento da psique do estrangeiro, principalmente um sul-americano diante das cortes americanas." Que "para alguém que é estrangeiro e totalmente leigo quanto à mentalidade do sistema penal americano é muito difícil conceber que é melhor confessar o crime do que negá-lo quando há evidência do mesmo e que o acusado não deve, a não ser em casos especialíssimos, prestar depoimento pessoal'. Para o Professor, o funcionário consular exerceria mais influência para convencer o criminoso a seguir o aconselhamento dos advogados americanos, sobre o plea bargaining. Isso porque, o funcionário consular conhece a realidade do país de acolhida, tem mais autoridade, ascendência, por isso pode proteger melhor os interesses do estrangeiro que se encontra 
Referiu-se ao procedimento contencioso internacional pendente na Corte Internacional de Justiça de forma irrelevante, limitando-se apenas à questão da força vinculante da ordem de medida provisória nos tribunais internos do País, e sequer referiu-se ao artigo 94 da Carta das Nações Unidas. ${ }^{116}$

O governo da Virgínia valeu-se do entendimento da Suprema Corte e, ignorando o pedido da própria Secretária de Estado, feito por carta, no dia anterior, FRANCISCO BREARD foi executado no mesmo dia, em 14 de abril de 1999, por meio de injeção letal.

Após o pedido de desculpas formal feito pelos Estados Unidos pela violação da Convenção de Viena de 1963, prometendo melhorar o cumprimento da Concenção de Viena, o Paraguai pediu por meio de uma carta apresentada à Corte em 02 de novembro de 1998 e o caso foi retirado da lista de contenciosos da Corte em 11 de novembro de 1999, sem haver, portanto, decisão de mérito. ${ }^{117}$ Daí porque a Corte não teve a oportunidade de se manifestar, inclusive, sobre a força vinculante das suas ordens de medidas provisórias.

\subsection{Contribuições do caso BREARD para o Direito Internacional Público}

Muito embora a Corte Internacional de Justiça não tenha proferido decisão de mérito, o caso é de relevante importância em termos de Direito Internacional. Depois do caso NOTTEBOHM ${ }^{118}$, trata-se de outro caso envolvendo

em dificuldade no Estado receptor. DOLINGER, Jacob. Os Estados Unidos perante o Direito Internacional. A decadência jurídica de uma grande nação, pp.106-107.

${ }^{116}$ Breard v. Greene, 523, 371, U.S, (14/04/1998) Supreme Court of the United States.

${ }^{117}$ SHEIK, MANI. From Breard to Medellin: Supreme Court Inaction or ICJ Activism in the Field of International Law?, p. 540.

${ }^{118}$ Corte Internacional de Julstiça. Nottebohm (Liechtenstein v. Guatemala), apresentado pelo governo de Liechtenstein contra a Guatemala em 17 de dezembro de 1951, para o fim de exercer a proteção diplomática em favor do Sr. Friedrich Nottebohn, cidadão de Liechtnstein, por atos praticados pela Guatemala contra seu cidadão, em violação do direito internacional, por tê-lo tratado como inimigo nacional, inclusive expondo-a a medidas de detenção infustificadas. Acontece que a Guatemala alegou que a nacionalidade fora convenientemente adquirida para livrar-se da nacionalidade alemã, em plena segunda guerra. 
diretamente um individuo submetido ao tribunal judicial das Nações Unidas, que, tradicionalmente, julga controvérsias entre Estados, o que levantou questionamentos sobre a própria competência jurisdicional da Corte. ${ }^{119}$ Além disso, criou um precedente no direito interno americano que representa um dos maiores desafios do direito internacional contemporâneo, a saber, a implementação de decisões internacionais no ordenamento jurídico interno, sobretudo em Estados federados, impedida por doutrina de direito interno; e a dúvida levantada a respeito da força vinculante das ordens de medida provisória da Corte. ${ }^{120}$

Para CARlos MAnuel VAsquez, a execução de Breard com a "benção" da Suprema Corte norte-americana, mas em desafio a uma ordem da Corte Internacional de Justiça, e um pedido da Secretária de Estado, levantou importantes questões concernentes à distribuição do poder e responsabilidades entre os estados e o governo federal na área das relações exteriores. ${ }^{121}$

Para SANJA DJAJIC, o caso ilustra bem a complexidade que é a relação entre direito internacional e direito interno - uma relação complexa e em constante desenvolvimento. O caso mostra que as cortes internacionais podem lidar com situações que envolvem o direito interno do Estado em litígio, e que envolve fatores como: a obrigação dos tribunais internos para o cumprimento das ordens e decisões da Corte Internacional de Justiça; a responsabilidade do Estado pela violação do

\footnotetext{
${ }^{119}$ O Juiz ODA, em declaração feita com respeito à ordem de medida provisória emitida pela Corte em 09 de abril de 1998, votou favoravelmente, com muito desconforto e em "termos humanitários", manifestou sua posição da seguinte forma: "I voted in favour of the Court's Order with great hesitation as I believed and I still believe that the request for the indication of provisional measures of protection submitted by Paraguay to the Court should have been dismissed. However, in the limited time - one or two days - given to the Court to deal with this matter, I have found it impossible to develop my points sufficiently to persuade my colleagues to alter their position", Reports of Judgments, advisory opinions and orders, 09/04/1998, p. 260.

${ }^{120} \mathrm{O}$ Advogado Geral dos Estados Unidos enviou uma carta à Suprema Corte, questionando a força vinculante das medidas provisórias ordenadas pela Corte nas cortes estaduais independentes dos Estados Unidos. Fez o mesmo no caso LAGRAND, acatado pelo Justice SOUTER. Federal Republic of Germany et. al. vs. United States et. al., 526 U.S. 111, per curiam. A Corte critica essa posição na sentença: "33. In the course of these proceedings, the United States Solicitor General as counsel of record took the position, inter. ulia, that "an order of the International Court of Justice indicating provisional measures is not binding and does not furnish a basis for judicial relief'. On the same date, the United States Supreme Court dismissed the motion by Germany, on the ground of the tardiness of Germany's application and of jurisdictional barriers under United States domestic law. LAGRAND (Germany $v$. United States of America), ICJ Reports of Judgments, Advisory Opinions and Orders, 27/06/2001, parág. 33.

${ }^{121}$ VAZQUEZ, Carlos Manuel. Breard, Printz, and the Treaty Power, p. 1317.
} 
direito internacional pelos seus tribunais internos; métodos de execução no ordenamento jurídico interno de decisões internacionais; o efeito das decisões dos tribunais internos no procedimento internacional e no direito internacional em si; a potência das doutrinas de direito interno para o não cumprimento do direito internacional; considerações de direitos humanos na estrutura horizontal do sistema internacional; formas para conciliar atitudes conflitantes e possibilitar total cumprimento com o direito internacional. Ao ter a Suprema Corte ignorado a ordem em decisão interlocutória da "Corte do Mundo (World Court)", os Estados Unidos subestimaram a autoridade do tribunal judicial das Nações Unidas, levantando questionamentos sobre o compromisso do país com o Direito Internacional. ${ }^{122}$

DJAJIC também ressalta que a Convenção de Viena sobre Relações Consulares de 1963 não é o único tratado a ser violentado pelos Estados Unidos no caso, mas a Carta das Nações Unidas e o Estatuto da Corte Internacional de Justiça, no que diz respeito à força vinculante das decisões desse tribunal internacional. Levantou questões quanto à validade jurídica dessas decisões, à interpretação de tratados internacionais e direito internacional consuetudinário; o tratamento à separação de poderes e federalismo no sistema jurídico norte americano ao encarar questões referentes a relações internacionais; e a proteção dos direitos humanos pelos tribunais norte americanos. O sistema jurídico interno do País, de certa forma, foi exposto na moldura jurídica internacional - o caso passou de interpretação de tratado internacional para implementação de decisões internacionais pelo sistema jurídico processual penal interno. ${ }^{123}$

\footnotetext{
${ }^{122}$ DJAJIC, Sanja. The Effect of International Court of Justice Decisions on Municipal Courts in the United States: Breard v. Greene, p. 30.

${ }^{123}$ DJAJIC, Sanja. The Effect of International Court of Justice Decisions on Municipal Courts in the United States: Breard v. Greene, p. 34.
} 


\section{Capítulo 5}

\section{Corte Internacional de Justiça - Caso laGrand: Alemanha vs. Estados Unidos da AmÉrica, APRESENTAdo EM 02 de MARÇO DE 1999}

Em 02 de março de 1999, o governo alemão apresentou perante a Corte Internacional de Justiça pedido de instauração de procedimento contencioso contra os Estados Unidos da América, por violações da Convenção de Viena sobre Relações Consulares de 1963. Na mesma oportunidade, apresentou pedido de emissão de ordem de Medida Provisória de proteção, em prol do Sr. WALTER BURNHART LAGRAND. ${ }^{124}$ A Alemanha alegou que os Estados Unidos, ao prender, deter, julgar, condenar e sentenciar os irmãos WALTER BURNHART LAGRAND e KARL HINZE LAGRAND à pena de morte, sem lhes informar o direito que tinham de receber assistência por parte do Consulado de sua nacionalidade e sem informarem a repartição consular alemã sobre suas prisões, violaram suas obrigações internacionais perante a Alemanha, em seu próprio direito, e no seu direito de conferir proteção diplomática de seus nacionais. Por essa razão, os processos criminais condenatórios deveriam ser anulados. Ainda, que ao aplicar doutrinas de direito interno para obstar o cumprimento de suas obrigações de Direito Internacional, os Estados Unidos estariam obrigados a restaurar o status quo ante com relação a WALTER LAGRAND. KARL já havia sido executado em 24 de fevereiro de 1999, razão pela qual a

124 LaGrand (Germany $v$. United States of America): Documentos disponíveis online em: $<$ http://www.icj-Corte Internacional

de Justiça.org/docket/index.php?p1=3\&p2=3\&k=04\&case $=104 \&$ code $=$ gus $\&$ p3 $=0>, \quad$ (acesso $\quad$ em 18/09/2009). Importante ressaltar que nessa data a Corte Interamericana de Direitos Humanos ainda não havia declarado ser o direito à assistência conforme o art. 36, parágrafo 1(b) da Convenção de Viena de 1963 um “direito humano", no Parecer Consultivo n. ${ }^{\circ}$ 16, de $1^{\circ}$ de outubro de 1999. 
Alemanha pediu reparação e garantia de medidas de não-repetição dos atos internacionalmente ilegais. $^{125}$

O caso claramente referia-se ao destino de dois indivíduos, ao invés de mais um grupo de vítimas "anônimas", como é comum em muitos casos abordados pela Corte. Os fatores políticos, tais como a postura abordada pelos Estados Unidos em caso envolvendo a polêmica pena de morte, certamente também desempenharam um papel, muito embora não se trate diretamente da pena capital. Para CARSTEN Hope, o caso pareceu resumir a esperança de que o Direito Internacional Público pode ajudar um indivíduo em perigo, para decidir sobre a sua vida ou morte. ${ }^{126}$

A Alemanha afirmou que houve uma conexão entre o que é visto como defesa inadequada dos irmãos LAGRAND e a condenação deles à pena morte, por não terem recebido a assistência consular oportuna. Alegou que se o consulado alemão tivesse sido devidamente informado sobre a prisão dos alemães, seus funcionários teriam fornecido imediatamente proteção, apoio e assistência aos seus nacionais, ajudando na preparação da sua defesa, na obtenção de um advogado

125 Inicial com pedido de abertura de procedimento contencioso contra os Estados Unidos, por violação da Convenção de Viena sobre Relações Consulares de 1963, protocolada na Secretaria da Corte Internacional de justiça em 02 de março de 1999 (Application). Disponível online em: <http://www.icj-Corte Internacional de Justiça.org/docket/files/104/7153.pdf> (acesso em 10/10.2009). Conforme CHRISTINA CERNA, é digno observar que nessa oportunidade, de "petição inicial", a Alemanha alegou que os Estados Unidos haviam violado uma obrigação para com a Alemanha, e que essa implicaria uma violação dos direitos individuais dos irmãos LaGrand. Ou seja, não foi ainda na "petição inicial" que a Alemanha alegou que o caráter do artigo 36 da Convenção de Viena Sobre Relações Consulares de 1963 havia assumido caráter de "direito humano", mas apenas na fase oral, alegando explicitamente que por se tratar de um direito humano, tornaria a eficácia da provisão ainda mais imperativa. Fundamentou a assertiva na "Declaração sobre os direitos humanos dos indivíduos que não são nacionais do país em que vivem", adotada pela Assembléia Geral da ONU em sua Resolução 40/144, de 13 de dezembro de 1985, que confirma que o direito ao acesso ao Consulado de seu país, assim como a informação sobre esse direito constituem direitos individuais do estrangeiro, devendo ser considerados direitos humanos dos estrangeiros. CERNA, Christina M., The right to consular notification as a human right, pp. 443 e 444.Em 02 de março de 1999 a Corte Interamericana de Direitos Humanos ainda não havia publicado a Opinião Consultiva n. ${ }^{\circ} 16$, fazendoo em 01 de outubro do mesmo ano, quando considerou ser o direito à assistência consular um legítimo direito humano, componente do devido processo legal. Observamos que os procedimentos orais no caso LaGrand ocorreram no ano 2000. Acreditamos que seria uma importante influência da Opinião Consultiva da Corte Interamericana de Direitos Humanos, alegada perante a Corte Internacional de Justiça.

${ }^{126}$ HOPPE, Carsten. Implementation of LaGrand and Avena in Germany and the United States: Exploring a Transatlantic Divide in Search of a Uniform Interpretation of Consular Rights, $p$. HopPE, Carsten. Implementation of LaGrand and Avena in Germany and the United States: Exploring a Transatlantic Divide in Search of a Uniform Interpretation of Consular Rights, p. 319. 
competente e no levantamento de provas atenuantes. $\mathrm{O}$ caso dos dois teria sido exaustivamente investigado e as provas atenuantes essenciais para à defesa, principalmente se coletadas na Alemanha, teriam sido apresentadas nas etapas decisivas do processo penal. Na verdade, para o governo alemão, KARL e WALTER LAGRAND foram mal representados, nenhuma prova atenuante foi produzida e os irmãos foram condenados à pena morte à margem do Direito Internacional. Os irmãos teriam escapado da pena de morte se as provas mencionadas tivessem sido introduzidas a tempo. ${ }^{127}$

Os Estados Unidos não negaram a violação do art. 36, 1(a)(b), da Convenção. No entanto, sustentaram que o direito de informação consular seria puramente inter-Estatal, muito embora indiretamente beneficiasse indivíduos. Pediram desculpas formais à Alemanha, e que estariam tomando medidas substanciais destinadas a evitar que as violações se repetissem. Ao ignorarem a existência de um procedimento internacional perante a Corte Internacional de Justiça, da emissão da ordem de medida provisória e logo uma decisão internacional direcionada contra si e seus tribunais internos, os Estados Unidos desafiaram a autoridade da Corte, o que levantou a questão sobre a própria força de implementação e cumprimento interno das decisões internacionais pelos Estados que se submetem às jurisdições internacionais. ${ }^{128}$

Mas antes de se adentrar em detalhes do caso na instância internacional, convém apresentarmos uma contextualização histórica do caso no âmbito jurídico interno americano. Em seguida, o objetivo será vincular o estudo do caso ao contexto contemporânero de Direito Internacional. O caso é importante não apenas com relação ao direito criminal interno dos Estados partes da Convenção, mas representa um marco em termos de Direito Internacional.

\footnotetext{
${ }^{127}$ LAGRAND CASE (Germany v. United States of America). Memorial of the Federal Republic of Germany Volume I (Text of the Memorial), 16 September 1999, par. 1.01.

${ }^{128}$ DJAJIC, Sanja. The Effect of International Court of Justice Decisions on Municipal Courts in the United States: Breard v. Greene, p. 29.
} 


\subsection{Antecedentes do caso}

Em 07 de janeiro de 1982, as autoridades policiais do estado norte americano do Arizona detiveram dois cidadãos alemães, KARL HiNZE e WALTER BERNHARD LAGRAND, pela tentativa de assalto à mão armada ao banco Valley National Bank, na cidade de Manara. Morreu o gerente, Ken HARTSOCK, e sofreu sérios ferimentos uma funcionária chamada DAWN LOPEZ. ${ }^{129}$

Em 17 de fevereiro de 1984 ambos foram condenados por homicídio de primeiro-grau, tentativa de homicídio, assalto à mão armada e por duas acusações de seqüestro, logo na primeira instância, havendo sido representados por advogado dativo, por falta de condições financeiras para arcar com advogado de sua escolha. Ocorre que o advogado dativo não argüiu a violação da Convenção de Viena Sobre Relações Consulares de 1963, tampouco procurou por circunstâncias atenuantes ligadas à criação sob circunstâncias sociais extremas.

Em 14 de dezembro de 1984, os irmãos LAGRAND foram então condenados à pena de morte por assassinato de primeiro grau, e por pena restritiva de liberdade pelos outros crimes. Foram detidos, julgados e condenados à morte sem terem sido oportunamente informados sobre o direito de assistência consular. Em 30 de janeiro de 1987 a Suprema Corte do estado do Arizona rejeitou os recursos de apelação ${ }^{130}$, da mesma forma, a Suprema Corte dos Estados Unidos rejeitou o pedido de Writ of Certionari ${ }^{131}$. Outra tentativa de recurso perante a Suprema Corte do estado do Arizona tampouco teve sucesso, negada em 1989 e em $1991^{132}$. Até então, os irmãos ainda não conheciam seus direitos previstos no artigo 36 da Convenção. Foi apenas em junho de 1992, quando todas as vias legais estaduais tinham sido

\footnotetext{
${ }^{129}$ Pouco depois de 8 h00 do dia 7 de janeiro de 1982, Karl LaGrand e seu irmão, Walter, entraram no Valley National Bank, em Marana. Armados com uma pistola de brinquedo, Karl tentou forçar Ken Hartsock, o gerente de 63 anos, para abrir o cofre. Hartsock não conseguia abrir o cofre porque ele não tinha a senha completa. Os irmãos, então, levaram Hartsock e Dawn Lopez, uma funcionária do banco, ao gabinete de Hartsock, e os amarraram. Depois de ameaçar Hartsock com um abridor de cartas, os irmãos começaram a bater nele. Hartsock morreu com 24 golpes. Tentaram matar Lopez golpeando-a por seis vezes, depois fugiram do banco. Informações disponíveis online em: <http://www.azcentral.com/specials/special32/articles/06240622EXElegrandkarl-ON.html> (acesso em 16/10/2009).

${ }^{130}$ State v LaGrand (Walter), 734 P 2d 563 (1987); State v LaGrand (Karl), 733 P 2d 1066 (1987).

131 Karl LaGrand v Arizona, 484 US 872 (1987); Walter LaGrand v Arizona, 484 US 872 (1987).

132501 U.S. 1259, 111 S.Ct. 2910, 2911, 115 L.Ed.2d 1074 (1991).
} 
esgotadas, que o principal posto consular alemão tomou conhecimento do caso dos irmãos e, por eles próprios, de que haviam tomado conhecimento de seus direitos previstos no art. 36 da Convenção por outros meios, que não por informação das autoridades do Arizona ${ }^{133}$. Em dezembro de 1992 funcionários consulares fizeram a eles a primeira visita oficial. A partir daí, uma nova rodada de processo de habeas corpus foi iniciada, referindo-se às violações da Convenção de Viena sobre Relações Consulares de $1963 .^{134}$

Em 24 de janeiro e 16 de fevereiro de 1995, o Tribunal Federal dos Estados Unidos para o Distrito de Arizona (Federal United States District Court for the District of Arizona) indeferiu o pedido de habeas corpus dos irmãos. Fora a primeira vez que se alegou a violação do artigo 36 da Convenção. O Tribunal fundamentou a decisão na doutrina de direito interno chamada "procedural default doctrine" 135 - porque os irmãos não reivindicaram seus direitos previstos no art. 36 da Convenção na instância criminal anterior, estadual, não poderiam fazê-lo em procedimento federal de Habeas Corpus. ${ }^{136}$ Isto, muito embora fosse óbvio que os

\footnotetext{
${ }^{133}$ No entanto, na audiência do Comitê de Misericórdia (Mercy Committee), em 23 de fevereiro de 1999, Procurador do Estado, Peasley, revelou que as autoridades do estado do Arizona tinha efetivamente conhecimento, desde 1982, que Karl e Walter LaGrand eram cidadãos alemães. No entanto, os Estados Unidos alegaram que pouco importa que desde 1982, funcionários da justiça (probation officers), ou autoridades da imigração, soubessem da nacionalidade alemã dos irmãos, porque essas não seriam as autoridades competentes, conforme a Convenção de Viena sobre Relações Consulares de 1963. In: Sentença - LaGrand (Alemanha v. Estados Unidos da América), 27 de junho de 2001 - Corte Internacional de Justiça, par. 16.

${ }^{134}$ LAGRAND (Germany $v$. United States of America), ICJ Reports of Judgments, Advisory Opinions and Orders, 27/06/2001, par. 22.

${ }_{135}$ "Is a federal rule that, before a state criminal defendant can obtain relief in federal court, the claim must be presented to a state court. If a state defendant attempts to raise a new issue in a federal habeas corpus proceeding, the defendant can only do so by showing cause and prejudice. Cause is an external impediment that prevents a defendant from raising a claim and prejudice must be obvious on its face. One important purpose of this rule is to ensure that the state courts have an opportunity to address issues going to the validity of state convictions before the federal courts intervene." $\mathrm{O}$ "United States District Court for the District of Arizona" considerou que os irmãos não haviam demonstrado um fator externo objetivo que os prevenisse de alegar a violação da Convenção antes, o que foi confirmado pelo "United States Court of Appeasl Ninth Circuit". Em 02 de novembro de 1998 a Suprema Corte dos Estados Unidos negou ulterior revisão desse julgamento. LAGRAND (Germany v. United States of America), ICJ Reports of Judgments, Advisory Opinions and Orders, 27/06/2001, parág, 23.

${ }^{136}$ LaGrand v Lewis, 883 F Supp 451 (Ariz, 1995); LaGrand v Lewis, 883 F Supp 469 (Ariz,1995). Os parágrafos 32 e 33 referem assim: É indiscutível que o Estado do Arizona não notificou o LaGrands dos seus direitos ao abrigo da Convenção. Também é indiscutível que esta alegação não foi levantada em qualquer procedimento estatal. A afirmação é, portanto, "procedurally defaulted" (tradução livre). Podemos abordar os méritos de uma ação "procedurally defaulted" se o requerente demonstrar a causa para a procedural default e prejuízo real como resultado de supostas violações de lei federal.Bonin v. Calderon, 77 F.3d 1155, 1158 (9th Cir.), cert. denied, 516 U.S. 1143, 116 S.Ct.
} 
irmãos não conheciam esses direitos naquela fase processual - porque as autoridades do Arizona deixaram de lhes informar a tempo.

KARL E WALTER LAGRAND foram formalmente notificados pelas autoridades competentes dos Estados Unidos sobre seus direitos de assistência consular em 21 de dezembro de 1998 - aproximadamente 15 anos após suas condenações à pena de morte. Em 15 de janeiro de 1999 a Suprema Corte do Arizona marcou a execução de KARL HINZE para o dia 24 de fevereiro de 1999, e a execução de seu irmão WALTER BURNHART para o dia 03 de março de 1999. Uma petição subseqüente foi apresentada à Suprema Corte do Arizona, mas o certiorari foi negado. Outros procedimentos em fevereiro de 1999 foram novamente sem sucesso $^{137}$, além de tratativas diplomáticas entre os governos da Alemanha e dos Estados Unidos. ${ }^{138}$ Não havia nenhum mecanismo jurídico interno efetivo capaz remediar esta situação, haja vista a doutrina de direito interno, a doctrine of procedural default. ${ }^{139}$

980, 133 L.Ed.2d 899 (1996). Para demonstrar a causa, o requerente deve demonstrar a existência de "algum fator objetivo externo à defesa que tenha impedido os esforços do advogado para dar cumprimento à regra processual do Estado. Murray v. Carrier, 477 U.S. 478, 488, 106 S.Ct. 2639, 2645, 91 L.Ed.2d 397 (1986); see also McCleskey v. Zant, 499 U.S. 467, 497, 111 S.Ct. 1454, 147172, 113 L.Ed.2d 517, reh'g denied, 501 U.S. 1224, 111 S.Ct. 2841, 115 L.Ed.2d 1010 (1991) (a causa é um impedimento externo, como a interferência do governo ou indisponibilidade razoável de base factual da alegação). Na falta de causa e prejuízo e, talvez, possamos considerar reivindicações "processualmente barradas" se, ao fazê-lo, implicasse na condenação ou a execução de "quem é realmente inocente". Schlup v. Delo, 513 U.S. 298, 321, 115 S.Ct. 851, 864, 130 L.Ed.2d 808 (1995).

${ }^{137}$ LaGrand v Stewart, 525 US 971 (1998) e LaGrand v Stewart, 170 F 3d 1158 (9th Cir, 1999);

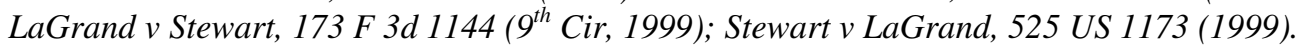

${ }^{138}$ Particularmente os Ministros da Justiça e das Relações Exteriores da Alemanha escreveram para seus colegas norte americanos em 27 de janeiro de 1999; no mesmo dia, o Ministro das Relações Exteriores alemão escreveu para o Governador do Arizona; o Chanceler alemão escreveu para o presidente Bill Clinton em 05 de fevereiro de 1999, referindo-se, no entanto, às penas capitais em geral, e não a questão sobre a falta de notificação consular, o que foi referido em carta posterior, enviada à secretário de estado norte americana em 22 de fevereiro de 1999, dois dias antes da execução de Karl Hinze.

${ }^{139}$ Esta é uma regra rigorosa da lei federal americana que emergiu da divisão federal dos poderes, que impede que um réu obtenha benefícios em tribunais federais, via o remédio do habeas corpus, a menos que o pedido tenha sido apresentado a um tribunal estadual ("É um princípio bem estabelecido do federalismo, que uma decisão do estado que repousa em uma base adequada de fundo na lei estadual é imune a revisão nos tribunais federais": Wainwright v. Sykes, 433 E.U. 72, 81 (1977)). O remédio baseado em novo pedido feito perante um Tribunal Federal é deferido apenas se a nova argüição puder mostrar que um impedimento externo impossibilitou o pedido de ser feito a um tribunal estadual ("causa") e prejuízo. US Code Collection. Title 28 (Judiciary and Judicial Procedure)> Part VI (Particular Proceedings)> Chapter 153 (Habeas Corpus)> $\$ 2254$ (State custody; remedies in Federal courts): (b) (1) An application for a writ of habeas corpus on behalf of a person in custody pursuant to the judgment of a State court shall not be granted unless it appears that: (A) the applicant has exhausted the remedies available in the courts of the State; or; (B) (i) there is an absence of available State corrective process; or (ii) circumstances exist that render such process ineffective to 
Em 23 de fevereiro de 1999, o "Arizona Board of Executive Clemency" rejeitou um pedido de clemência de KARL HINZE. Pela lei interna do estado, isso significa que o Governador ficara impedido de conceder a Clemência. ${ }^{140}$ No mesmo dia, nova tentativa de recurso baseada na falta de notificação consular foi negada pelo “Arizona Superior Court in Pima County”. Em 24 de fevereiro de 1999, no dia da execução de KARL, o "United States Court of Appeals Ninth Corcuit" confirmou que a falta de notificação não podia ser alegada, haja vista a regra de direito interno, chamada "doctrine of procedural default". ${ }^{141}$

KARL LAGRAND foi executado em 24 de fevereiro de 1999, por injeção letal ${ }^{142}$, após algumas tentativas diplomáticas frente ao "Comitê de Misericórdia do Arizona" (Arizona Mercy Commitee), pedidos de clemência, para evitar a execução da sentença de morte, em violação crassa de Direito Internacional. A data da execução de WALTER LAGRAND, cujo método, escolhido por ele, seria o da câmara de gás letal, já estava marcada para o dia 03 de março de 1999, ou seja, no

protect the rights of the applicant. (2) An application for a writ of habeas corpus may be denied on the merits, notwithstanding the failure of the applicant to exhaust the remedies available in the courts of the State. (3) A State shall not be deemed to have waived the exhaustion requirement or be stopped from reliance upon the requirement unless the State, through counsel, expressly waives the requirement. (c) An applicant shall not be deemed to have exhausted the remedies available in the courts of the State, within the meaning of this section, if he has the right under the law of the State to raise, by any available procedure, the question presented.

${ }^{140}$ No mesmo dia, Walter teve outro pedido baseado na falta de notificação consular negado pelo “Arizona Superior Court in Pima County", com base na "doctrine of procedural default". LAGRAND (Germany v. United States of America), ICJ Reports of Judgments, Advisory Opinions and Orders, 27/06/2001, parágs, 25-28.

${ }^{141}$ Karl LaGrand também alegou que a execução por gás letal constituía pena cruel e incomum. O Tribunal Distrital concluiu que Karl LaGrand não tinha conseguido demonstrar a causa ou prejuízo, vigorando a regra da "doctrine of procedural default". O Tribunal de Apelações reverteu a decisão. O Nono Circuito encontrou um prejuízo, e concluiu que a falha de Karl LaGrand ao não alegar a questão do método de execução por gás letal foi dispensado porque não havia nenhuma base legal ou de fato para o pedido quando ele exercia o apelo direto a um tribunal estadual. O prejuízo foi mostrado porque ele era agora confrontado com a execução de um método que o próprio Nono Circuito havia anteriormente considerado inconstitucional com base na Emenda Oitava. Supreme Court of the United States. Terry Stewart, director, Arizona Department of Corrections, et al. v. Walter LaGrand. On application to lift restraining order and petition for writ of certiorari to the Ninth Circuit Court of Appeals, March 3, 1999.

${ }^{142}$ Ambos os irmãos escolheram a câmara de gás como método de execução, na esperança de que os tribunais alegassem a inconstitucionalidade, em face da $8^{\mathrm{a}}$ Emenda, por se tratar de método cruel e incomum. Mas quando esta tática falhou, porque o $9^{\circ}$ Circuito (9th U.S. 9th Circuit Court of Appeals) considerou que Karl havia escolhido a câmara de gás espontaneamente, mas encontrou um "prejuízo" na alegação dele, e determinou a suspensão da execução por esse método. Daí o Estado do Arizona recorreu à Suprema Corte que, por $8 \times 1$, reverteu a decisão do $9^{\circ}$ Circuito. Karl LaGrand aceitou a oferta de última hora, em 24 de fevereiro, de receber então uma injeção letal. In: LaGrand v. Stewart, No. 99-99004, at 10-11 (CA9 February 24, 1999). 
dia seguinte à data da apresentação da reclamação perante a Corte Internacional de Justiça.

\subsection{Curiosidades sobre o caso: a condição social dos irmãos LaGrand nos Estados Unidos}

Os irmãos WALTER e KARL LAGRAND nasceram na Alemanha, na cidade de Augusburgo, respectivamente em 26 de janeiro de 1962 e 20 de outubro de 1963, e eram de nacionalidade alemã. Os meninos eram cuidados pela avó ou por uma babá. Quando a avó ficou doente, foram colocadas pela mãe em um orfanato, durante dois anos, onde teriam sofrido falta de cuidados. Até que EMMA, a mãe, os recuperasse, as crianças já sofreriam de insônia e stress pós-traumático. Em 1966, EMMA casou-se com MASIE LAGRAND, um soldado americano que vivia na mesma cidade alemã, que adotou os dois meninos e a irmã mais velha deles, PATRICIA. A família mudou-se permanentemente para os Estados Unidos, em 1967, quando os irmãos tinham aproximadamente quatro e cinco anos. Em seguida MASIE LAGRAND foi enviado para a Guerra do Vietnã, retornando muito diferente para os Estados Unidos, o que causou o divórcio entre ele e EMMA, em 1973.

Os irmãos visitaram a Alemanha apenas uma vez na vida, em 1974, por seis meses. Assim, ao tempo da prisão, em 1982, por seus comportamentos e fala, mais pareciam americanos do que alemães, e sequer falavam bem a língua materna. Nenhum se identificou como sendo nacional alemão. As autoridades competentes do estado do Arizona alegaram que não sabiam que eram estrangeiros, até meados de $1983 .^{143}$

\footnotetext{
${ }^{143}$ Informações obtidas da própria sentença do Caso LaGrand, de 27 de junho de 2001, par. 13, assim como da interessante página da Internet, disponível online em: < http://www.executedtoday.com/2008/03/03/1999-walter-lagrand/> (acesso em 15/10/2009). Consta que o primeiro registro de delinqüência dos irmãos ocorreu em 1978 quando, ao fugirem de casa, cometeram roubo.
} 
Christina CERnA ${ }^{144}$ salienta que, haja vista a integração social dos irmãos KARL e WALTER LAGRAND na cultura norte americana, poderse-ia cogitar que dificilmente seria esse um caso ideal que demonstrasse a necessidade de assistência consular a nível de igualdade no acesso equitativo à justiça para os estrangeiros. Embora tenham vivido nos Estados Unidos a maior parte de suas vidas, e tenham sido adotados por um cidadão dos Estados Unidos, eles nunca foram naturalizados pelo Serviço Nacional de Imigração, ou seja, nunca adquiriram a nacionalidade norte-americana - mantiveram exclusivamente a nacionalidade alemã. Mesmo assim, a Corte Internacional de Justiça estabeleceu que, ainda que o estrangeiro domine o idioma e possua contato cultural com o Estado Receptor em que se encontrar, ao ser privado de liberdade, por qualquer motivo que seja, deve ser informado sobre o direito de notificação e acesso à assistência consular, pelo fator nacionalidade.

\subsection{A apresentação do contencioso pela Alemanha perante a Corte Internacional de Justiça e a ordem de medida provisória}

Em 02 de março de 1999, exatamente 27 horas antes da data agendada para a execução de WALTER, e depois que falharam todos os esforços, jurídicos e diplomáticos, praticados pela Alemanha, para tentar impedir a execução de KARL LAGRAND, ocorrida em 24 de fevereiro, a Alemanha apresentou pedido de instauração de procedimento contencioso internacional na Secretaria da Corte Internacional de Justiça, contra os Estados Unidos, por violações da Convenção de Viena sobre Relações Consulares de $1963 .{ }^{145}$ Basicamente, alegou que os Estados Unidos violaram suas obrigações internacionais perante a Alemanha, diretamente, por conta da violação do artigo 36 da Convenção de 1963, e ainda indiretamente, ao violarem o instituto da proteção diplomática em nome de seus nacionais.

\footnotetext{
${ }^{144}$ CERNA, Christina M., The right to consular notification as a human right, pp. 442 e 443.

145 Salienta-se que, nesta ocasião, a Corte Interamericana de Direitos Humanos ainda não havia declarado em seu Parecer Consultivo n. ${ }^{\circ} 16$ de 01 de outubro de 1999, que a assistência consular compõe o corpus iuris dos direitos humanos. Daí talvez o motivo de a Alemanha, ao contrário do México, no ulterior caso Avena, instituído em 2001, pelo México, não ter alegado desde a inicial que se tratava de violação de um legítimo direito humano componente do devido processo legal.
} 
$\mathrm{Na}$ mesma oportunidade da inicial, a Alemanha apresentou pedido urgente de ordem de Medida Provisória de Proteção com vistas à evitar a execução de WALTER, cuja execução estava marcada para o dia seguinte, 03 de março de 1999. 146

No mesmo dia, o Arizona "Board of Executive Clemency" considerou o caso de WALTER LAGRAND, contrário à comutação da sua pena de morte, mas recomendando ao Governador para que concedesse 60 dias de suspensão à execução, haja vista a ação interposta pela Alemanha na Corte, o que foi negado pela governadora JANE DEE HULl. ${ }^{147} \mathrm{O}$ caso foi levado pela Alemanha à Suprema Corte dos Estados Unidos, para buscar a aplicação interna da Medida Provisória concedida pela Corte Internacional de Justiça em 03 de março de 1999, em que ordenou os Estados Unidos a tomar todas as medidas ao seu alcance para garantir que WALTER LAGRAND não fosse executado enquanto se aguardava a decisão final no processo, e deveriam informar ao Tribunal da ONU todas as medidas que tomaram para a aplicação da ordem.

A Suprema Corte dos Estados Unidos declarou-se incompetente, devido à XI Emenda da Constituição, que proíbe tribunais federais de receberem processos de Estados estrangeiros contra um estado norte-americano. ${ }^{148}$ Com relação ao caso da Alemanha contra os Estados Unidos, declarou que a "doctrine of procedural default" aplicava-se à alegação "tardia" Convenção de Viena de 1963, e que mesmo se essa regra processual interna entrasse em conflito com o tratado, teria

\footnotetext{
${ }^{146} \mathrm{O}$ pedido foi no sentido de que os Estados Unidos tomassem todas as medidas à sua disposição para assegurar que Walter não fosse executado antes da decisão de mérito do caso, tendo em vista a extrema gravidade: "The United States should take all measures at its disposal to ensure that Walter LaGrand is not executed pending the final decision in these proceedings, and should inform the Court of all the measures which it has taken in implementation of that Order". A segunda ordem foi a de o Governo Federal transmitir a odem de medida provisória ao governador do estado do Arizona. Request for the indication of Provisional Measures of Protection submitted by the government of the Federal Republic of Germany. Por carta, o Ministro das Relações Exteriores alemão pediu à Secretária de Estado norte americana para que insistisse com o governador do Arizona pela suspensão da execução de Walter.

${ }^{147}$ A governadora fundamentou sua decisão com base na "justice" e nas vítimas: "I have carefully weighed the recommendation from the Board of Executive Clemency. However, in the interests of justice and with the victims in mind, I have decided to allow the execution to go forward." Disponível online em: < http://www.guardian.co.uk/world/1999/mar/04/julianborger> (acesso em 02/11/2010).

148 "The Judicial power of the United States shall not be construed to extend to any suit in law or equity, commenced or prosecuted against one of the United States by Citizens of another State, or by Citizens or Subjects of any Foreign State".
} 
sido revogada pela lei federal posterior, a "Anti-Terrorism and Effective Death Penalty Act of 1996", que legislou explicitamente a doutrina da "omissão processual", a "doctrine of procedural default". ${ }^{49}$

Em 03 de março de 1999, a Corte atendeu ao pedido urgente apresentado pela Alemanha quando do depósito da inicial. Foi a primeira vez que a Corte emitiu ordem de Medida Provisória próprio motu ${ }^{150}$, tendo em vista a extrema urgência e a presença de prejuízo irreparável, ou seja, sem ouvir a parte contrária - e sequer haveria tempo para isso. A Corte tomou o cuidado de esclarecer que o caso não dizia respeito ao direito interno dos estados federais dentro dos Estados Unidos, de aplicação pena de morte para os crimes mais hediondos, e reforçou sua função exclusiva de resolver litígios internacionais entre os Estados, inter alia, quando surgem da interpretação ou aplicação de tratados internacionais, e não de agir como um "Tribunal Internacional de Apelação Criminal”. ${ }^{151}$

A Corte indicou unanimemente duas Medidas Provisórias de Proteção em favor da Alemanha. Primeiramente, ordenou que os Estados Unidos tomassem "todas as medidas ao seu dispor" para suspender a execução de WALTER LAGRAND, marcada para o dia seguinte, até a sentença final do caso no âmbito da própria Corte. Em segundo lugar, considerando que a responsabilidade internacional de um Estado é constatada pela ação dos órgãos competentes e autoridades do Estado, quaisquer que sejam, a Corte determinou que o governo norte americano teria, por conseguinte, a obrigação internacional de transmitir aquela Ordem ao governo do estado do

\footnotetext{
${ }^{149}$ Nos Estados Unidos, assim como acontece no Direito brasileiro, uma legislação do Congresso anula tratados anteriores conflitantes. U.S. Supreme Court (Federal Republic of Germany et. al. vs. United States et. al., 526 U.S. 111, per curiam).

${ }^{150} \mathrm{O}$ procedimento está previsto no artigo 75 do Regulamento da Corte Internacional de Justiça: "Article 75: 1. The Court may at any time decide to examine proprio motu whether the circumstances of the case require the indication of provisional measures which ought to be taken or complied with by any or all of the parties. 2. When a request for provisional measures has been made, the Court may indicate measures that are in whole or in part other than those requested, or that ought to be taken or complied with by the party which has itself made the request. 3. The rejection of a request for the indication of provisional measures shall not prevent the party which made it from making a fresh request in the same case based on new facts".

151 "Whereas the issues before the Court in this case do not concern the entitlement of the federal states within the United States to resort to the death penalty for the most heinous crimes; and whereas, further, the function of this Court is to resolve international legal disputes between States, inter alia when they arise out of the interpretation or application of international conventions, and not to act as a court of criminal appeal." LAGRAND (Germany v. United States of America), ICJ Reports of Judgments, Advisory Opinions and Orders, 03/03/2001, parág. 25.
} 
Arizona, que, da mesma forma, deveria agir em conformidade com os compromissos internacionais assumidos pelos Estados Unidos.

A Alemanha recorreu à Suprema Corte norte americana para fazer valer a ordem da Corte Internacional de Justiça para tentar suspender a execução de WALTER LAGRAND, isso tudo a menos de duas horas antes da execução. O pedido foi indeferido, e WALTER foi executado em seguida, ${ }^{152}$ pelo método cruel e incomum da câmara de gás. ${ }^{153}$ A Suprema Corte, em termos semelhantes aos do caso BREARD, impôs inúmeros obstáculos de direito interno, como a doutrina que equivale ao nosso prequestionamento, "doctrine of procedural default", que não era incompatível com a Convenção de Viena sobre Relações Consulares de 1963, e mesmo que fosse, prevaleceria o disposto na lei federal posterior Anti-Terrorism and Effective Death Penalty Act de 1996, que legislou a doutrina de maneira expressa (para fins de lei local, legislação do Congresso posterior anula tratados anteriores que possuam conteúdo conflitante). ${ }^{154}$ Declarou-se incompetente no que diz respeito à causa da Alemanha contra o estado do Arizona, referindo-se à XI Emenda da Constituição americana. Acompanhando o parecer do Solicitor General ${ }^{155}$, a Suprema Corte

${ }^{152}$ Federal Republic of Germany et. al. vs. United States et. al., 526 U.S. 111, per curiam. On application for temporary restraining order or preliminary injunction and on motion for leave to file a bill of complaint No. 127, Orig. (A-736). Decided March 3, 1999.

${ }^{153}$ Até o momento, WALTER LAGRAND foi o último homem a ser executado pelo método da câmara de gás, pelo estado de Arizona, em 3 de março de 1999. Ele foi um dos apenas 11 prisioneiros mortos por esse meio bárbaro, entre as 1.099 execuções ocorridas até então, desde que a pena de morte fora restabelecida em 1976. Os Estados Unidos introduziram a câmara de gás como um método de execução no início do século XX. O primeiro prisioneiro do corredor da morte, executado com "ar envenenado" foi o imigrante chinês GEE JON, que morreu na prisão no Estado de Nevada em 1924. Em relação ao outros métodos em uso no momento - a cadeira elétrica, enforcamento, e pelotão de fuzilamento - o gás era considerada a forma mais "humana" de tirar a vida de uma pessoa. Disponível online em: < http://www.executedtoday.com/2008/03/03/1999-walter-lagrand/> (acesso em 15/10/2009). Corroboramos a informação em diversos sites de ONG's americanas sérias como a Death Penalty information Center, disponível online em: <http://www.deathpenaltyinfo.org/> (acesso em 15/10/2009); TAYLOR, Rupert, Gas Chamber Execution, Hydrogen Cyanide Used to Kill in United States, publicado na Suite101.com, em 29/09/2009, disponível online em: $<$ http://peacesecurity.suite101.com/article.cfm/gas_chamber_execution> (acesso em 15/10/2009).

${ }_{154}^{15}$ Federal Republic of Germany et. al. vs. United States et. al., 526 U.S. 111, per curiam.

155 Este ente, na cadeia hierárquica, vem em segundo após o "Advogado Geral da Uniao", o responsável pela fiscalização do cumprimento da lei e da administração da justiça. Ele apresentou uma carta pela qual se opôs a qualquer tipo de adiamento da execução de WALTER LAGRAND. Na sua opinião, a "Convenção de Viena não fornece uma base para suspender a sua execução", e questionou a força vinculativa de uma ordem da Corte Internacional de Justiça indicadora de medida provisória. O Advogado Geral acrescentou, porém, que ele "não teve tempo para ler a matéria completa nem para digerir o conteúdo." Supreme Court of the United States. No. 127, Orig. (A-736) The Federal Republic of Germany et al. v. United States et . On application for temporary restraining order or preliminary injunction and on motion for leave to file a bill of complaint, March $3^{\text {rd }}, 1999$. 
encontrou outras "barreiras", como a "imunidade soberana do país", e ressaltou que a ação fora apresentada apenas duas horas antes da execução programada do alemão. 156

\subsection{A sentença da Corte Internacional de Justiça sobre o caso LAGRAND}

Ao contrário do Paraguai, que retirou o caso da lista de contenciosos em novembro de 1999, após a execução de seu nacional, a Alemanha prosseguiu, resultando na sentença expedida pela Corte em 27 de junho de 2001, que decidiu por condenar os Estados Unidos a "revisão e reconsideração" das sentenças e condenações, por violação das suas obrigações internacionais contidas no artigo 36 da Convenção de Viena Sobre Relações Consulares de 1963, que cria sim direitos individuais que podem ser argüidos pelo Estado nacional do preso estrangeiro perante a Corte, por meio da proteção diplomática, e por ignorarem a ordem de medida provisória proprio motu do dia 03 de março de 1999.

Abaixo estão os principais pontos da sentença, que trazem inovações em termos de Direito Internacional Público, que interferem no direito interno dos Estados partes da Convenção, no sentido da interpretação e aplicação interna do tratado.

a) Quanto ao reconhecimento pela Corte Internacional de Justiça da previsão de direitos individuais pelo artigo 36 (1) (b) da Convenção de Viena sobre Relações Consulares de 1963

A Corte estabelece que o artigo 36. 1(b) determina as obrigações que o Estado Receptor tem perante o indivíduo estrangeiro detido e Estado que o envia. Prevê que, a pedido do indivíduo detido, o Estado Receptor tem o dever de informar o Posto Consular do Estado que envia, sobre a detenção do indivíduo seu nacional, e

\footnotetext{
${ }^{156}$ Supreme Court of the United States. No. 127, Orig. (A-736) The Federal Republic of Germany et al. v. United States et al. On application for temporary restraining order or preliminary injunction and on motion for leave to file a bill of complaint, March $3^{\text {rd }}, 1999$.
} 
isso "sem tardar". Prevê ainda que deve ser transmitida qualquer comunicação pela pessoa detida endereçada ao Posto Consular, pelas autoridades competentes do Estado Receptor, e "sem tardar". O parágrafo termina com a seguinte passagem: "As referidas autoridades devem informar a pessoa em causa, sem demora, sobre seus direitos ao abrigo desta alínea". Além disso, nos termos do artigo 36, parágrafo 1 (c), o direito do Estado que envia de prestar assistência consular ao seu nacional detido não pode ser exercido tão somente "se ele se opuser expressamente". Com base na clareza do texto literal dessas disposições, a Corte conclui que o artigo 36. 1(b) "cria direitos individuais" que, por força do artigo $1^{\circ}$ do Protocolo Adicional, pode ser invocado perante a Corte Internacional de Justiça, pelo Estado nacional (que envia) da pessoa detida no território do Estado Receptor, direitos que foram violados no caso. ${ }^{157}$

A Corte tomou o cuidado de não se manifestar a respeito do argumento adicional da Alemanha, apresentada em seu Memorial escrito, de que o direito do indivíduo a ser imediatamente informado ao abrigo do artigo 36.1(b), da Convenção "não só é um direito individual, mas tem hoje assumido o caráter de um legítimo direito humano, tornando a eficácia desta disposição ainda mais imperativa". A Corte não encontrou necessidade para considerar o argumento da Alemanha, de que a assistência consular seria um direito humano, vez que já havia decidido sobre a violação por parte dos Estados Unidos.

JOAN FITZPATRICK, fez importantes reflexões sobre a implementação da decisão do caso LAGRAND pelos Estados Unidos, o que ela definiu como “importantes lições”. Entre elas o fato de a Corte ter sido hesitante e desconfiada no sentido de definir se esse direito individual seria um direito humano. Ela ressalta que

157 "The Court notes that Article 36, paragraph $1(b)$, spells out the obligations the receiving State has towards the detained person and the sending State. It provides that, at the request of the detained person, the receiving State must inform the consular post of the sending State of the individual's detention "without delay". It provides further that any communication by the detained person addressed to the consular post of the sending State must be forwarded to it by authorities of the receiving State "without delay". Significantly, this subparagraph ends with the following language: "The said authorities shall inform the person concerned without delay of /lis rights under this subparagraph" (emphasis added). Moreover, under Article 36, paragraph 1 (c), the sending State's right to provide consular assistance to the detained person may not be exercised "if he expressly opposes such action". The clarity of these provisions, viewed in their context, admits of no doubt." LAGRAND (Germany vs. United States of America), ICJ Reports of Judgments, Advisory Opinions and Orders, 27/06/2001, par. 77. 
a Corte Internacional de Justiça não mencionou o Parecer Consultivo n. ${ }^{\circ} 16$ da Corte Interamericana de Direitos Humanos, que interpretou o direito de informação sobre a assistência consular para preso estrangeiro como sendo um dos componentes do pacote em constante transformação que formam as garantias mínimas de devido processo legal, no caso do o preso estrangeiro para preparar sua defesa, e receber um julgamento justo adequadamente. Para a ela, no entanto, o direito de assistência consular, assim como as Convenções de Genebra de 1949, repousa firmemente sobre os princípios tradicionais de reciprocidade. Não é um direito erga omnes, como são as garantias previstas no Pacto Internacional de Direitos Civis e Políticos da ONU. 158

Para CHRISTIAN TAMS ${ }^{159}$, a decisão da Corte, de reconhecer que o art. 36, 1 (b) da Convenção de Viena de 1963 cria direitos individuais, confirma a visão do Direito Internacional moderno, de que direitos individuais não necessariamente derivam de tratados internacionais clássicos de direitos humanos, mas são um "fenômeno persuasivo", visão compartilhada com a Corte Interamericana de Direitos Humanos. Porém, enquanto esse Tribunal, quando da Opinião Consultiva n. ${ }^{\circ} 16$ de 01 de outubro de 1999, focou na discussão entre o direito individual à assistência consular e direitos humanos procedimentais, o principal órgão judicial das Nações Unidas teria preferido evitar a "politização da controvérsia".

BRUNO SIMMA observa que as expressões "direitos humanos" e "pena de morte" são referidas apenas uma vez na decisão do caso LAGRAND. Ele acredita que essa omissão diz respeito justamente à Opinião Consultiva n. ${ }^{0} 16$ da Corte Interamericana de Direitos Humanos, e à "questão da fragmentação e a relação entre tribunais internacionais." 160 A esse respeito, JOHN QUIGLY sustenta que a posição de ambos os tribunais, com relação ao artigo 36 da Convenção, são

\footnotetext{
${ }^{158}$ FITZPATRICK, Joan e outros. Consular rights and the death penalty after LaGrand, pp. 309-310. ${ }^{159}$ TAMS, Christian J. Consular Assistance: Rights, Remedies and Responsibility. Comments o n the ICJ's Judgement in the LaGrand case, p. 1257.

${ }^{160}$ No mesmo encontro, CATHERINE BROWN critica a decisão LaGrand, ao dizer que não basta definir que se trata de um direito individual, e questiona qual seria essa relação com o procedimento processual penal do Estado receptor, e se essa disposição criaria a obrigação para o Estado parte da Convenção de incorporar em seu sistema jurídico-criminal interno, a ponto do indivíduo levantar uma nulidade. FITZPATRICK, Joan e outros. Consular rights and the death penalty after LaGrand, p. 311.
} 
perfeitamente consistentes, porque condenaram, de certa forma, a imposição da pena de morte sem garantir ao indivíduo condenado, o direito de informação sobre assistência consular, e tendo sido obstado por institutos de direito interno, como a XI Emenda à Constituição americana e a doctrine of procedural default rule. ${ }^{161}$

THEODOR MERON ${ }^{162}$ afirmou que a Corte, na decisão do caso LAGRAND, ao reconhecer que o art. 36.1 (b) da Convenção de Viena de 1963 cria direitos individuais, ainda que pelo exercício do Estado do direito de proteção diplomática, refletiu o "aumento da sensibilidade para as questões envolvendo direitos humanos", muito embora tenha se abstido de decidir se esse direito do preso estrangeiro é um direito humano. Conforme MERon, o instituto da proteção diplomática dos cidadãos no estrangeiro “continua a servir a um propósito útil para o avanço dos direitos humanos". ${ }^{163}$

\section{b) Quanto às medidas provisórias da Corte Internacional de Justiça} e o reconhecimento de sua força vinculante - uma interpretação com base em costume internacional consagrado pela Convenção de Viena sobre Direito dos Tratados de 1969

A Corte teve a oportunidade de consolidar, pela primeira vez, o que nem a Corte Permanente de Justiça Internacional havia feito antes, o entendimento acerca dos efeitos jurídicos vinculantes das Medidas Provisórias previstas pelo artigo 41 do seu Estatuto ${ }^{164}$, e pelos artigos 73-78 de seu Regulamento, que conferem a

\footnotetext{
${ }^{161}$ FITZPATRICK, Joan e outros. Consular rights and the death penalty after LaGrand, p. 317.

${ }^{162}$ MERON $_{2}$ Theodor. International Law in the Age of Human Rights. General Course on Public International Law, pp. 199-200 e 310-12. Ele salienta o trabalho de JOHN DUGARD, Relator especial do primeiro relatório sobre proteção diplomática da CDI, que fez importante contribuição para esclarecer a relação entre o instituto e a proteção de direitos humanos, ao mostrar que a proteção diplomática pode ser empregada como meio de proteção de direitos humanos, mas que não existe nenhum direito individual à proteção diplomática. Ainda é considerada um direito exclusivo do Estado a seu critério. Todavia, a visão clássica de que, pela proteção diplomática, o Estado está reivindicando seus próprios direitos é cada vez mais contestada. A proteção diplomática é mais vista como um direito procedimental, enquanto o "direito material está investido no indivíduo".

${ }^{163}$ LaGrand (Germany vs. United States of America), ICJ Reports of Judgments, Advisory Opinions and Orders, 27/06/2001, par. 77.

${ }^{164}$ Article 41: 1. The Court shall have the power to indicate, if it considers that circumstances so require, any provisional measures which ought to be taken to preserve the respective rights of either
} 
possibilidade de emitir medidas necessárias para a manutenção dos direitos das partes, e cujo desrespeito representa, sim, violação de Direito Internacional. Trata-se de decisão interlocutória que não pode prejudicar a decisão de mérito do caso, e tampouco a questão referente à responsabilidade do Estado. Por isso que as questões materiais são reservadas para a decisão de mérito. A sentença do caso LAGRAND esclarece que o caráter interlocutório da medida provisória lida apenas com questões incidentais que não influenciam na decisão final de mérito, não a destituindo de seu caráter judicial. ${ }^{165} \mathrm{O}$ cumprimento de medidas provisórias não pode causar dano aos Estados partes do caso - servem simplesmente para efetivar a administração justiça internacional. $^{166}$

SANJA DJAJIC explica que o propósito principal das Medidas Provisórias é a preservação de direitos que são o objeto da disputa em curso na Corte, para que o procedimento não se torne sem sentido, antes mesmo de ser encerrado. Garantem, ainda, uma resposta mais correta e adequada para uma situação urgente que possa ameaçar os direitos dos Estados partes do litígio e, assim, preservam-se provas, evitam-se danos irreparáveis, assim como a prorrogação desnecessária da disputa. ${ }^{167}$ Ela ressalta que, muito embora as medidas provisórias possuam força vinculante, no entanto, isso não significa que sejam executáveis no plano interno do Estado, daí porque parece que a Corte comunica-se com o Estado no plano das relações internacionais, um método apropriado para duas entidades internacionais. Prescreve uma "atribuição" para o Estado, com exposição de motivos,

party. 2. Pending the final decision, notice of the measures suggested shall forthwith be given to the parties and to the Security Council. Statute of the International Court of Justice.

165 "Whereas the power of the Court to indicate provisional measures under Article 41 of the Statute of the Court has as its object to preserve the respective rights of the parties pending the decision of the Court, and presupposes that irreparable prejudice should not be caused to rights which are the subject of dispute in judicial proceedings". Passage through the Great Belt (Fin. Den.), 1991. I.C.J. Reports of Judgments, Advisory Opinions and Orders (July 29), par. 16. "B. The Government of the United States of America and the Government of the Islamic Republic of Iran should not take any action and should ensure that no action is taken which may aggravate the tension between the two countries or render the existing dispute more difficult of solution;”. United States Diplomatic and Consular Staff in Tehran (United States of America v. Iran). I.C.J. Reports of Judgments, Advisory Opinions and Orders (December 15/1979).

${ }^{166}$ DJAJIC, Sanja. The Effect of International Court of Justice Decisions on Municipal Courts in the United States: Breard v. Greene, p.39.

${ }^{167}$ DJAJIC, Sanja. The Effect of International Court of Justice Decisions on Municipal Courts in the United States: Breard v. Greene, p. 35. 
como sendo juridicamente vinculante, e o Estado, por sua vez, resolve como bem implementar a decisão internacional em seu ordenamento jurídico interno. ${ }^{168}$

A Corte limitou a questão da força vinculante das medidas provisórias essencialmente à interpretação do artigo 41 de seu Estatuto, que é idêntico ao da Corte Permanente de Justiça Internacional, preferindo fazê-la de acordo com o "Direito Internacional Consuetudinário, consagrado no artigo 31 da Convenção de Viena sobre o Direito dos Tratados de 1969", cujo inciso I dispõe que "um tratado deve ser interpretado de boa fé, em conformidade com o sentido comum atribuível aos termos em seu contexto e em à luz do objeto do tratado e finalidade". ${ }^{69}$

Em seguida, comparou as versões em inglês e francês do dispositivo, fazendo um histórico da sua implementação. ${ }^{170}$ Decidiu que em caso de divergência entre as versões igualmente autênticas dos Estatutos, nem esses e tampouco a Carta das Nações Unidas indicam como proceder. Desta forma, na ausência de acordo entre as partes a este respeito, é oportuno referir-se ao parágrafo $4^{\circ}$ do artigo 33 da Convenção de Viena sobre o Direito dos Tratados de 1969, que, na opinião da Corte reflete o "Direito Internacional Costumeiro". Esta disposição diz "quando a comparação dos textos autênticos revela uma diferença em sentido que a aplicação dos artigos 31 e 32 não eliminam, adotar-se-á o sentido que, tendo em conta o objeto

\footnotetext{
${ }^{168}$ DJAJIC, Sanja. The Effect of International Court of Justice Decisions on Municipal Courts in the United States: Breard v. Greene, p. 42.

${ }^{169}$ A Corte foi cautelosa, isso porque os Estados Unidos não ratificaram a Convenção de Viena de 1969, mas seus preceitos codificaram direito consuetudinário existente e, portanto, vinculam Estados mesmo sem a ratificação. Citamos o Parecer Consultivo da Corte Internacional de Justiça, sobre o caso da Namíbia, que dispõe o seguinte: "As regras estabelecidas pela Convenção de Viena sobre o Direito dos Tratados em matéria de extinção da relação de um tratado em virtude da violação (adotada sem voto) pode, em muitos aspectos, ser considerada como uma codificação do direito consuetudinário existente sobre o assunto. À luz dessas regras, apenas a violação substancial de um tratado justifica a extinção, tal violação ser definido como: "(a) uma rejeição do tratado não sancionada pela presente Convenção; ou (6) a violação de uma disposição essencial para a realização de o objeto ou fim do tratado "(art. 60, par. 3). Reports of Judgments, Advisory Opinions and Orders. Legal Consequences for States of the Continued Presence of South Africa in Namibia (South West Africa) notwithstanding security council Resolution 276 (1970). Advisory Opinion of 21 june 1971, par. 94.

${ }^{170}$ Ressaltou inclusive a participação fundamental do brasileiro RAUL FERNANDES, quem sugeriu a primeira versão, no Conselho da Liga das Nações: The initial preliminary draft of the Statute of the Permanent Court of International Justice, as prepared by the Committee of Jurists established by the Council of the League of Nations, made no mention of provisional measures. A provision to this effect was inserted only at a later stage in the draft prepared by the Committee, following a proposal from the Brazilian jurist Raul Fernandes. LAGRAND (Germany v. United States of America), ICJ Reports of Judgments, Advisory Opinions and Orders, 27/06/2001, par. 105.
} 
e a finalidade do tratado, melhor conciliar os textos". Que à luz do artigo 59 do Estatuto, o contexto do artigo 41 é, quando as circunstâncias pedem, no sentido de impedir que a Corte seja prejudicada no exercício de suas funções, e para que os respectivos direitos das partes em litígio também sejam preservados, o que implica que essas medidas devem ser vinculantes.

A Corte também leva em conta o artigo 94 da Carta das Nações Unidas ${ }^{171}$, cuja expressão "conformar-se com as decisões da Corte" não diz respeito apenas aos efeitos vinculantes das sentenças finais, mas também das suas ordens de medidas provisórias. ${ }^{172} \mathrm{Ou}$ melhor, a expressão "decisões" compreende todas as decisões da Corte Internacional de Justiça, inclusive as decisões interlocutórias, tais como as medidas provisórias. ${ }^{173}$

SHEIK MANI ressalta que esta parte da sentença pode muito bem ser considerada a mais importante para o futuro da credibilidade da Corte Internacional de Justiça. Ao estabelecer que as suas ordens de medidas provisórias são vinculantes, deu um passo significativo para "dar dentes" às suas ordens. No entanto, ele ressalta que as decisões internacionais continuam a não ter um mecanismo de aplicação

\footnotetext{
${ }^{171}$ Artigo 94. 1. Cada Membro das Nações Unidas se compromete a conformar-se com a decisão da Corte Internacional de Justiça em qualquer caso em que for parte. 2. Se uma das partes num caso deixar de cumprir as obrigações que the incumbem em virtude de sentença proferida pela Corte, a outra terá direito de recorrer ao Conselho de Segurança que poderá, se julgar necessário, fazer recomendações ou decidir sobre medidas a serem tomadas para o cumprimento da sentença. Além desses, mencionamos outros dispositivos do Estatuto da Corte Internacional de Justiça, que igualmente sugerem o caráter vinculante das medidas provisórias. São esses: Artigo 38. 1. A Corte, cuja função seja decidir conforme o direito internacional as controvérsias que sejam submetidas, deverá aplicar; 2. as convenções internacionais, sejam gerais ou particulares, que estabeleçam regras expressamente reconhecidas pelos Estados litigantes; 3. o costume internacional como prova de uma prática geralmente aceita como direito; 4. os princípios gerais do direito reconhecidos pelas nações civilizadas; 5. as decisões judiciais e as doutrinas dos publicitários de maior competência das diversas nações, como meio auxiliar para a determinação das regras de direito, sem prejuízo do disposto no Artigo 59. 6. A presente disposição não restringe a faculdade da Corte para decidir um litígio ex aequo et bono, se convier às partes. Artigo 59. A decisão da Corte não é obrigatória senão para as partes em litígio e respeito ao caso alvo de decisão. Artigo 60. A sentença será definitiva e inapelável. Em caso de desacordo sobre o sentido ou desfecho da sentença, a Corte interpretará a solicitação de qualquer das partes.

${ }^{172}$ LAGRand (Germany $v$. United States of America), ICJ Reports of Judgments, Advisory Opinions and Orders, 27/06/2001, par. 102.

${ }^{173}$ Mencionamos ainda os seguintes dispositivos da Carta da ONU, que apontam para o caráter vinculante das medidas provisórias: Artigo 25: Os Membros das Nações Unidas concordam em aceitar e executar as decisões do Conselho de Segurança, de acordo com a presente Carta; Artigo 103: No caso de conflito entre as obrigações dos Membros das Nações Unidas, em virtude da presente Carta e as obrigações resultantes de qualquer outro acordo internacional, prevalecerão as obrigações assumidas em virtude da presente Carta.
} 
viável, porque pela própria característica horizontal do Direito Internacional, ao contrário dos regimes jurídicos internos, não existe um poder de execução das decisões. $^{174}$

Sobre a responsabilidade internacional pela violação da Medida Provisória em questão, a Corte ressaltou que a Alemanha solicitou que a Corte julgasse e declarasse que apenas os Estados Unidos violaram sua obrigação jurídica internacional para dar cumprimento à ordem dos 03 de março de 1999, e nada sobre a consequiência disso. Também salientou que os Estados Unidos sofreram grande pressão de tempo, neste caso, devido às circunstâncias em que a Alemanha tinha iniciado o processo, 27 horas antes da execução de WALTER LAGRAND, e se, por ventura, tivesse que decidir a conseqüência da violação da Medida Provisória ordenada em questão, teria tomado em consideração esses fatores, caso a Alemanha tivesse incluído um pedido de indenização. ${ }^{175}$

\section{c) Quanto ao costume internacional da proteção diplomática e a exaustão dos recursos de direito interno}

A Alemanha alegou que os Estados Unidos violaram suas obrigações legais internacionais perante a Alemanha, por seu próprio direito, e em seu direito de conferir proteção diplomática a seus nacionais. Os Estados Unidos, em contrapartida, alegaram que a Corte não teria competência para julgar a questão da proteção diplomática, porque, à luz do Protocolo Adicional, nada teria a ver com a interpretação da Convenção de Viena de 1963. Na tentativa de uma "manobra

\footnotetext{
${ }^{174}$ SHEIK, MANI. From Breard to Medellin: Supreme Court Inaction or ICJ Activism in the Field of International Law? 546.

LAGRAND (Germany $v$. United States of America), ICJ Reports of Judgments, Advisory Opinions and Orders, 27/06/2001, parág. 98.

175 "The Court observes finally that in the third submission Germany requests the Court to adjudge and declare only that the United States violated its international legal obligation to comply with the Order of 3 March 1999: it contains no other request regarding that violation. Moreover, the Court points out that the United States was under great time pressure in this case, due to the circumstances in which Germany had instituted the proceedings. The Court notes moreover that at the time when the United States authorities took their decision the question of the binding character of orders indicating provisional measures had been extensively discussed in the literature, but had not been settled by its jurisprudence. The Court would have taken these factors into consideration had Germany's submission included a claim for indemnification." LAGRAND (Germany v. United States of America), ICJ Reports of Judgments, Advisory Opinions and Orders, 27/06/2001, par. 116.
} 
jurídica", apontaram para a distinção que haveria entre competência sobre os tratados e competência sobre o direito consuetudinário, e observaram que "ainda que ambos tivessem o mesmo conteúdo, cada um teria sua aplicabilidade em separado", porque o tratado em questão lidaria apenas com assistência consular e não com proteção diplomática. ${ }^{176}$

Alegaram ainda, que não haveria relação entre o caso e os casos de proteção diplomática envolvendo reivindicações econômicas pelo Estado em nome de seus cidadãos. Ainda, que o direito de um Estado de garantir assistência consular aos seus cidadãos detidos em outro país, bem como o de argüir em foros internacionais as reivindicações econômicas de seus cidadãos, por meio do instituto da proteção diplomática, trata-se de sentidos juridicamente diferentes. Até porque, a para as Estados Unidos o direito de assistência consular não seria um direito individual, mas que o individuo seria beneficiado indiretamente por um direito exclusivamente do Estado. ${ }^{177}$

Ademais, o País alegou a falta da exaustão dos recursos internos, havendo esbarrado na doutrina interna da procedural default doctrine, porque a violação deveria ter sido levantada pelos irmãos na primeira instância, e que os Estado Unidos não poderiam ser prejudicados por um erro estratégico dos advogados da defesa naquela fase processual. ${ }^{178}$ A Corte estabeleceu que não seria necessária a exaustão dos recursos de direito interno, porque foi uma doutrina de direito interno que barrou o remédio à violação da Convenção de Viena sobre Relações Consulares, e desde $1992 .{ }^{179}$

A Corte não aceitou a tese de que a Alemanha com base nos direitos individuais dos irmãos LAGRAND ultrapassaria a sua jurisdição, porque a proteção

\footnotetext{
176 "Legally, a world of difference exists between the right of the consul to assist an incarcerated national of his country, and the wholly different question whether the State can espouse the claims of its national through diplomatic protection." LAGRAND (Germany $\boldsymbol{v}$. United States of America), ICJ Reports of Judgments, Advisory Opinions and Orders, 27/06/2001, parág. 40.

77 LAGRAND (Germany $v$. United States of America), ICJ Reports of Judgments, Advisory Opinions and Orders, 27/06/2001, parág. 76.

${ }^{178}$ LAGRAND (Germany v. United States of America), ICJ Reports of Judgments, Advisory Opinions and Orders, 27/06/2001, parág. 58.

${ }^{179}$ LAGRAND (Germany v. United States of America), ICJ Reports of Judgments, Advisory Opinions and Orders, 27/06/2001, parágs. 59-60.
} 
diplomática é um conceito de Direito Internacional Consuetudinário. O Estado-parte de um tratado que reconhece direitos individuais pode assumir o caso em nome de seus nacionais, e instituir um processo judicial internacional, com base em uma cláusula geral de competência no tratado. ${ }^{180}$

Outro aspecto definido pela Corte é o fato de o artigo 36 da Convenção impor obrigações idênticas para todos os Estados-partes, independentemente da gravidade da infração, de e das sanções que podem ser impostas ao acusado. Dependendo da gravidade, um pedido de desculpas pode ser suficiente a título de reparação. ${ }^{181}$ A Corte considerou irrelevante para efeitos do presente caso se os LAGRAND A necessidade de prejuízo ao processo criminal, conforme alegado pelos Estados Unidos, porque é suficiente a Convenção conferir esses direitos, e que a Alemanha e os LAGRANDS foram impossibilitados de exercêlos por conta de doutrina de direito processual penal interno. ${ }^{182}$

JOAN FITZPATRICK salienta que, muito embora essa não seja a questão em jogo, o caso não deixou de expor internacionalmente o lado obscuro da pena de morte, geralmente restrita aos elementos marginalizados da comunidade, cujos direitos básicos são significadamente violados durante as fases investigatórias e de julgamento. Estrangeiros deixam de apresentar objeções oportunas por falha de seus advogados dativos, e esbarram na doutrina interna "doctrine of procedural default". 183

Tanto a Corte Internacional de Justiça quanto a Corte Interamericana de Direitos Humanos referiram-se a "penas severas". No entanto, é importante

${ }^{180}$ LAGrand (Germany $v$. United States of America), ICJ Reports of Judgments, Advisory Opinions and Orders, 27/06/2001, parág. 42.

${ }^{181}$ LAGRAND (Germany $v$. United States of America), ICJ Reports of Judgments, Advisory Opinions and Orders, 27/06/2001, parág. 42.

${ }^{182}$ LAGRAND (Germany $v$. United States of America), ICJ Reports of Judgments, Advisory Opinions and Orders, 27/06/2001, par. 74.

${ }^{183} \mathrm{O}$ fato de a representação dos irmãos LaGrand não terem alegado o direito à assistência consular em tempo oportuno, e essa falha ter afetado a defesa deles, é um exemplo, o qual ela chama de "sistema hermético de inadimplência processual" que comanda a disponibilidade de habeas corpus na justiça federal. Ela salienta que a decisão LaGrand deixa em aberto a questão da reparação adequada para remediar a violação do artigo 36 (1)(b). Porque o direito individual diz respeito de informação, e não à assistência consular em si, é difícil determinar exatamente o dano causado por essa violação em qualquer caso determinado. FITZPATRICK, Joan e outros. Consular rights and the death penalty after LaGrand, pp. 309 e 310. 
esclarecer que o caso LAGRAND não diz respeito a pena de morte, mas sobre a violação do artigo 36 da Convenção de Viena sobre Relações Consulares de 1963. Os direitos previstos por esse dispositivo, de informação sobre o direito de assistência consular, devem ser garantidos para o estrangeiro assim que privado de liberdade, e ao Posto Consular de sua nacionalidade, se assim ele não se opor expressamente. A Corte esclarece que a Convenção de Viena sobre Relações Consulares de 1963 impõe idênticas obrigações aos Estados-partes, independentemente da gravidade da ofensa, ou da pena imposta. Todavia, isso não significa que a reparação da violação desse artigo deve ser idêntica em todas as situações. Ou seja, enquanto um pedido formal de desculpas pode remediar algumas situações, em outras não será suficiente. ${ }^{184}$

No geral, a decisão do caso LAGRAND é balanceada e bem argüida. Muito embora não tenha sido proclamada a tempo de salvar a vida dos irmãos LAGRAND, oferece uma base para solucionar futuras violações do direito de informação sobre a assistência consular de maneira mais segura, e serve como base da decisão do caso AvENA, que se examinará na sequência. Ao afirmar a importância da assistência consular e a necessidade da sua implementação efetiva no âmbito dos sistemas jurídico-criminais internos dos Estados, a Corte Internacional de Justiça esclarece que o Direito Internacional não é neutro nessa questão, e que os Estados são obrigados internacionalmente a cumprir internamente com suas obrigações assumidas perante toda a comunidade internacional.

${ }^{184}$ LAGRAND (Germany $v$. United States of America), ICJ Reports of Judgments, Advisory Opinions and Orders, 27/06/2001, par. 63. 


\section{Capítulo 6}

\section{Corte Internacional de Justiça - Caso Avena: México vs. Estados Unidos da AMÉRICA, APRESENTADO EM 09 DE JANEIRO DE 2003 (AVENa AND OTHER MEXICAN Nationals - MEXICO V. UNITED STATES OF AMERICA)}

Oito meses após a sentença do caso LAGRAND, de 27 de junho de 2001, o México apresentou pedido de abertura de procedimento contencioso perante a Corte Internacional de Justiça, em 09 de janeiro de 2003. O motivo foram as condenações à pena de morte de CARlos AVEnA GuILlen e outros 53 cidadãos mexicanos, em nove estados norte-americanos, sem terem sido propriamente informados sobre o direito de informação e notificação sobre a assistência consular, um direito humano. Além disso, o México alegou que tanto o governo federal americano como suas subdivisões políticas estaduais estariam obrigados a respeitar os compromissos internacionais assumidos pelo País, e que o cumprimento de uma condenação pela Corte Internacional de Justiça não poderia ocorrer por meio da clemência executiva. O México também pediu que a Corte ordenasse medida provisória, como tentativa de evitar a execução de três dos mexicanos da lista da inicial.

Os Estados Unidos insistiram que nem a Convenção de Viena sobre Relações Consulares de 1963, ou outro tratado internacional de direitos humanos reconhece a assistência consular como sendo um "direito humano" e, assim, a não observância não poderia invalidar um procedimento criminal interno, porque seria um direito puramente inter-Estatal. Interessante porque os Estados Unidos, em caso levado à julgamento no passado (1979), sobre os Reféns em Teerã, argumentaram 
em sentido contrário perante a Corte Internacional de Justiça no passado, dizendo o seguinte: ${ }^{185}$

\begin{abstract}
"A principal function of the consular officer is to provide varying kinds of assistance to nationals of the sending State, and for this reason, the channel of communication between consular officers and nationals must at all times remain open. Indeed, such communication is so essential to the exercise of consular functions that its preclusion would render meaningless the entire establishment of consular relations. (...) Article 36 establishes rights not only for the consular officer but, perhaps even more importantly, for the nationals of the sending State who are assured access to consular officers and through them to others".
\end{abstract}

Muitas perguntas permanecem sem resposta, incluindo as opções do Congresso norte-americano para dar efeito interno para a decisão da Corte. Ainda assim, a Corte teve a oportunidade de aprofundar a interpretação decorrente dos dois casos anteriores, BREARD e LAGRAND, sobre o direito de informação sobre assistência consular para preso estrangeiro, e as consequiências de sua violação.

A Corte Internacional de Justiça encontrou provas de competência prima facie (um requisito básico para a concessão de medidas provisórias) com base na existência de um litígio, na acepção do artigo I do Protocolo Facultativo da Convenção Relativo à Solução de Controvérsias, de 24 de abril de 1963, em que o México e os Estados Unidos eram partes, sem reserva.

Com relação à primeira ordem de medida provisória, de 05 de fevereiro de 2003, foi a primeira a ser emitida, após a deliberação histórica da sentença do caso LAGRAND, que considerou que essas são decisões são vinculantes. A inovação feita neste caso foi de que a Corte Internacional de Justiça substituiu o qualificador daquela ordem - "à sua disposição" - por um termo mais incisivo, o "necessário", dando a entender a obrigatoridade de cumprimento da ordem. ${ }^{186}$

\footnotetext{
${ }^{185}$ Memorial apresentado pelos Estados Unidos, perante a Corte Internacional de Justiça, no caso dos reféns em Teerã: Estados Unidos vs Irã, de 1979 (United States Diplomatic and Consular Staff in Tehran (United States of America v. Iran), p. 174.

186 "The Court, unanimously: 1. Indicates the following provisional measures: a) The United States of America shall take all measures necessary to ensure that Mr. César Roberto Fierro Reyna, Mr. Roberto Moreno Ramos and Mr. Osvaldo Torres Aguilera are not executed pending final judgment in these proceedings; (b) The Government of the United States of America shall inform the Court of all measures taken in implementation of this Order. Case concerning Avena and other Mexican nationals (Mexico $v$. United States of America), ICJ Reports of Judgments, advisory opinions
} 
Em 31 de março de 2004, a Corte proferiu sentença condenando os Estados Unidos a providenciarem, por meio de sua própria escolha, "revisão e reconsideração" dos julgamentos e sentenças condenatórias ${ }^{187}$. Esta mudança aparentemente trivial, não apenas representou uma vitória para o México, como também estabeleceu um precedente internacional único. A Corte tornou inequívoca, no teor do mérito da decisão, como o México havia solicitado, a obrigação de serem juridicamente vinculantes as ordens de medidas provisórias, devendo serem "impostas", e terem o respectivo "resultado necessário".

De certa forma, então, a Corte simplesmente reafirmou um princípio axiomático do Direito Internacional: um Estado não pode invocar o seu direitointernoou estrutura jurídica interna para desculpar ou justificar violações do direito internacional. ${ }^{188}$ Sua importância como um precedente internacional, finalmente, é pareado por seu significado quanto aos efeitos potenciais, jurídicos e políticos, para os Estados Unidos, conforme veremos a seguir

Os 52 cidadãos mexicanos condenados à morte em nove diferentes estados dos Estados Unidos da América estavam vivos quando a Corte emitiu seu julgamento. Apenas três dos nacionais tinham esgotado todas as vias de recursos judiciais nos Estados Unidos, enquanto os 49 restantes estavam em diferentes fases do processo nos tribunais estaduais e federais. Na decisão do caso AvENA e outros nacionais mexicanos, de 31 de março de 2004, a Corte teve a oportunidade de

and orders (05/02/2003), parág. 59. Em contrapartida, talvez por ainda não ter, na ocasião, deliberado sobre a força executória das medidas provisórias, fazendo-o quando da sentença, no caso LAGRAND, a Corte ordenou o seguinte: 1. Indicates the following provisional measures: (a) The United States of America should take all measures at its disposal to ensure that Walter LaGrand is not executed pending the final decision in these proceedings, and should inform the Court of all the measures which it has taken in implementation of this Order; (b) The Government of the United States of America should transmit this Order to the Governor of the State of Arizona. In: LAGRAND (Germany v. United States of America), ICJ Reports of Judgments, Advisory Opinions and Orders, 03/03/1999, par. 22.

187 Até o momento da sentença, da lista original de 54 demandantes havia sido reduzida para 52, porque um reclamante tinha dupla cidadania, mexicana e americana, e outro havia sido informado dos seus direitos consulares.

${ }^{188}$ Reparation for Injuries Suffered in the Service of the United Nations, [1949] ICJ Rep. 174, 180 (11 April); Treatment of Polish Nationals and Other Persons of Polish Origin or Speech in the Danzig Territory, Corte Internacional de Justiça (ser. A/B) No. 44 (1932), at 4; Free Zones of Upper Savoy and the District of Gex (France v. Switzerland), Corte Internacional de Justiça (Ser. A) No. 24 (1930), at 12.). 
avançar a linha de seus precedentes diretos, o caso BREARD, encerrado sem julgamento, e o caso LAGRAND.

A novidade tem a ver com a inserção direta da proteção do ser humano, desde o pedido inicial de abertura de procedimento contencioso, especialmente em casos de pena de morte, porque ninguém pode ser privado da vida arbitrariamente $^{189}$ - a presença e atuação do ser humano, ainda que amparada pelo Estado, em foro internacional tradicionalmente competente para julgar contenciosos entre Estados. O México mencionou na petição inicial que havia recorrido, em termos semelhantes, à Comissão e à Corte Interamericana de Direitos Humanos. ${ }^{190}$

A Corte Internacional de Justiça diretamente confrontou a ligação entre as obrigações de Direito Internacional com o funcionamento do direito processual criminal interno do Estado norte americano. O sistema de justiça criminal dos Estados Unidos é necessariamente levado em consideração no caso internacional, não só devido à natureza das principais obrigações de fundo, mas também por causa do tipo de reparação procurada e concedida a favor do México, de revisão e reconsideração das sentenças e condenações dos seus tribunais internos, por conta de "violações de direito internacional", no caso, da Convenção de Viena sobre Relações Consulares de $1963 .^{191}$

189 "Further, violation of the rights established by Article 36 of the Vienna Convention constitutes a violation of the human rights of Mexican nationals, especially in cases which may result in the imposition of a death sentence." Case concerning Avena and other Mexican nationals (Mexico v. United States of America), Application instituting proceedings, 9 January 2003, parag. 271.

${ }^{190}$ Faced with this continuing pattern and practice of Vienna Convention violations by United States authorities, Mexico sought a declaration of its rights in the Inter-American Court of Human Rights. In an advisory opinion, that Court held that failure to respect the right to consular assistance established by Article 36.1(b) of the Vienna Convention would prejudice the due process rights of foreign nationals such that the imposition of capital punishment under such circumstances would violate the human right not to be deprived of life arbitrarily. (The Right to Information on Consular Assistance in the Framework of the Guarantees of the Due Process of Law, Advisory Opinion OC-16/99 of 1 October 1999. Series A No. 16.) Case concerning Avena and other Mexican nationals (Mexico $v$. United States of America), Application instituting proceedings, 9 January 2003, parag. 65.

${ }^{191}$ Observa-se a constatação da Corte na sentença do caso Avena: "The Court has been informed of the variety of types of proceedings and forms of relief available in the criminal justice systems of the United States, which can differ from state to state. In very general terms, and according to the description offered by both Parties in their pleadings, it appears that the 52 cases may be classified into three categories: 24 cases which are currently in direct appeal; 25 cases in which means of direct appeal have been exhausted, but post-conviction relief (habeas corpus), either at State or at federal level, is still available; and three cases in which no judicial remedies remain. The Court also notes that, in at least 33 cases, the alleged breach of the Vienna Convention was raised by the defendant either during pre-trial, at trial, on appeal or in habeas corpus proceedings, and that some of these 
A Corte Internacional de Justiça esclarece que a clemência executiva, muito embora o importante papel histórico na administração da justiça criminal americana, quando esgotados os meios judiciais, não seria suficiente para reparar a violação do artigo 36.1 da Convenção de Viena sobre Relações Consulares de 1963. ${ }^{192}$ A obrigação de "revisão e reconsideração", deve ser efetuada por meio de "um procedimento que garanta que o peso dado à violação dos direitos estabelecidos na Convenção de Viena, seja qual for o resultado real dessa revisão e reconsideração", e "por meio de processo judicial". Essa seria a forma adequada de reparação, com vistas a determinar, examinando os fatos em cada caso, e se a violação resultou em real prejuizo ao réu, no processo de administração da justiça criminal do Estado Receptor.

A Corte ressaltou, no entanto, que os procedimentos adequados de clemência podem complementar a revisão judicial e reconsideração, particularmente quando o sistema judicial não tomou em devida conta a violação dos direitos estabelecidos na Convenção de Viena. ${ }^{193}$ Mas a maior preocupação é a de esclarecer que, o que estava sendo julgado pela Corte não é sistema criminal interno do Estado

claims were dismissed on procedural or substantive grounds and others are still pending." Case concerning Avena and other Mexican nationals (Mexico v. United States of America), ICJ Reports of Judgments, advisory opinions and orders (27/06/2004), parág. 20.

192 "As regards the clemency procedure, the Court notes that this performs an important function in the administration of criminal justice in the United States and is "the historic remedy for preventing miscarriages of justice where judicial process has been exhausted" (Herrera v. Collins, 506 U.S. 390 (1993) at pp. 411-412). The Court accepts that executive clemency, while not judicial, is an integral part of the overall scheme for ensuring justice and fairness in the legal process within the United States criminal justice system. It must, however, point out that what is at issue in the present case is not whether executive clemency as an institution is or is not an integral part of the "existing laws and regulations of the United States", but whether the clemency process as practised within the criminal justice systems of different states in the United States can, in and of itself, qualify as an appropriate means for undertaking the effective "review and reconsideration of the conviction and sentence by taking account of the violation of the rights set forth in the Convention", as the Court prescribed in the LaGrand Judgment (I.C.J. Reports 2001, p. 514, para. 125). (...) The Court considers nevertheless that appropriate clemency procedures can supplement judicial review and reconsideration, in particular where the judicial system has failed to take due account of the violation of the rights set forth in the Vienna Convention. Case concerning Avena and other Mexican nationals (Mexico $v$. United States of America), ICJ Reports of Judgments, advisory opinions and orders (27/06/2004), parágs. 142-143.

${ }^{193}$ The Court would emphasize that the "review and reconsideration" prescribed by it in the LaGrand case should be effective. Thus it should "take account of the violation of the rights set forth in [the] Convention" (I.C.J. Reports 2001, p. 516, para. 128 (7) and guarantee that the violation and the possible prejudice caused by that violation will be fully examined and taken into account in the review and reconsideration process. Lastly, review and reconsideration should be both of the sentence and of the conviction. Case concerning Avena and other Mexican nationals (Mexico v. United States of America), ICJ Reports of Judgments, advisory opinions and orders (27/06/2004), parág. 138. 
Receptor, isto é, não são as sentenças e condenações à pena de morte, a causa da violação do tratado internacional, mas as violações de Direito Internacional que as precederam, contra o art. 36.1 da Convenção de Viena sobre Relações Consulares de 1963.

De forma geral, a Corte Internacional de Justiça decidiu nos mesmos termos do julgamento do caso LAGRAND, datado de 27 de junho de 2001, com alguns avanços, os quais elencamos a seguir.

\subsection{Quanto ao reconhecimento pela Corte Internacional de Justiça da previsão de} direitos individuais pelo artigo 36 (1) (b) da Convenção de Viena sobre Relações Consulares de 1963 - e quanto à alegação de se tratar de um direito humano?

Na decisão do caso AVEnA, de 31 de março de 2004, recordando o que já havia deliberado na decisão do caso LAGRAND, a Corte conclui que existe no artigo 36.1(b) da Convenção uma "circunstância especial de interdependência" entre os direitos do Estado que envia e os direitos dos seus nacionais privados de liberdade no território do Estado Receptor. Pode o México pedir à Corte para se pronunciar sobre a violação dos direitos que alega ter sofrido tanto diretamente, assim como pela violação dos direitos individuais conferidos aos seus cidadãos. Daí porque o dever de esgotar os recursos internos não se aplica. Por essas razões, a Corte não considera necessário lidar com a alegação do México de violação de uma "posição distinta ao do instituto da proteção diplomática". ${ }^{194}$

As obrigações do artigo 36.1 da Convenção, no primeiro momento, são cumpridas no âmbito interno do Estado receptor. Somente quando esse processo for concluído e os recursos internos esgotados, o Estado que envia teria o direito de expor perante a Corte Internacional de Justiça, reclamações individuais dos seus cidadãos por meio do exercício do instituto da proteção diplomática. A Corte, no

${ }^{194}$. Case concerning Avena and other Mexican nationals (Mexico v. United States of America), ICJ Reports of Judgments, advisory opinions and orders (31/03/2004), parág. 40. 
entanto, verificou que o México não estava atuando exclusivamente nessa base, ou seja, em nome de seus nacionais, porque sustenta suas afirmações baseando-as sobre o prejuízo que alega ter sofrido diretamente, e também por seus nacionais, como resultado da violação pelos Estados Unidos das obrigações que lhe incumbem por força do artigo 36, parágrafo 1 (a), (b) e (c)

Outro fato importantíssimo é que ao decidir sobre a $4^{\mathrm{a}}$ objeção quanto a sua jurisdição, apresentada pelos Estados Unidos, de que não teria competência para dispor sobre direitos humanos, a Corte responde que isso seria uma questão de interpretação da Convenção de Viena sobre Relações Consulares, para a qual teria competência sim. ${ }^{195}$ No entanto, observou que nem o texto nem o objeto, tampouco o travaux préparatoires da Convenção, apóiam a conclusão do México, de que seria um direito humano fundamental componente das garantias do devido processo legal. ${ }^{196}$

\subsection{Quanto à interpretação da expressão "sem tardar", a partir de norma costumeira consagrada pela Convenção de Viena sobre Direito dos Tratados}

A Corte concluiu que a Convenção não define expressamente o sentido do termo "sem tardar" do artigo 36, 1(b) da Convenção de Viena. A interpretação pela Corte foi feita de acordo com os artigos 31 e 32 da Convenção de Viena sobre Direito dos Tratados de 1969. Começa interpretando o artigo 36.1 (b), que possui três elementos inter-relacionados: a) o direito do indivíduo de ser imediatamente informado de seus direitos ao abrigo do artigo 36.1(b); b) a direito do Posto Consular, de ser imediatamente notificado da detenção do indivíduo, se ele assim não se opuser expressamente e; c) a obrigação do Estado Receptor de transmitir, "sem tardar", a comunicação endereçada ao Posto Consular, sobre seu nacional detido. Ainda, que o dever do Estado Receptor de informar o indivíduo

\footnotetext{
195 Case concerning Avena and other Mexican nationals (Mexico v. United States of America), ICJ Reports of Judgments, advisory opinions and orders (31/03/2004), parág. 35.

${ }^{196}$ Case concerning Avena and other Mexican nationals (Mexico $v$. United States of America), ICJ Reports of Judgments, advisory opinions and orders (31/03/2004), parág. 124.
} 
surge assim que se perceber que se trata de um estrangeiro, ou assim que houver motivos para suspeitar que a pessoa é, provavelmente, um estrangeiro. Precisamente quando isso pode ocorrer varia de acordo com as circunstâncias, ou seja, não deve ser interpretado como "imediatamente após a prisão e antes do interrogatório". ${ }^{197}$

E haja vista a diversidade cultural da sociedade norte americana, a língua que uma pessoa fala, ou sua aparência, não indica necessariamente que ele é um estrangeiro. Desta forma, a Corte sugeriu que o dever de informar todo cidadão estrangeiro detido de seu direito de assistência consular poderia ser equiparado à leitura dos direitos MIRANDA WARNING. ${ }^{198}$

\section{a) Quanto ao costume internacional da proteção diplomática}

Igualmente ao caso LAGRAND, os Estados Unidos alegaram que em vários dos 52 casos, não havia ocorrido o requisito costumeiro da exaustão dos recursos de direito interno, tampouco o procedimento de clemência. A Corte, retomando a decisão do caso LAGRAND, observou que os direitos individuais dos cidadãos mexicanos devem ser afirmados, em qualquer caso, em primeiro lugar, no âmbito do ordenamento jurídico interno dos Estados Unidos. E quando esse procedimento está concluído e os recursos locais se esgotam é que México teria o direito de expor a pedidos individuais de seus cidadãos por meio do costume internacional de proteção diplomática. No entanto, a Corte concliou que, no caso, o México sofrera prejuízos tanto diretamente, e também indiretamente por meio de seus nacionais, como resultado da violação pelos Estados Unidos das obrigações que

\footnotetext{
${ }^{197}$ Case concerning Avena and other Mexican nationals (Mexico v. United States of America), ICJ Reports of Judgments, advisory opinions and orders (31/03/2004), parág. 63, 87, 88.

${ }^{198}$ Estes direitos incluem, nomeadamente: 1) o direito de permanecer calado; 2) o direito de ter um advogado presente durante o interrogatório, e; 3) o direito de ter um advogado nomeado às custas do governo, se a pessoa não pode pagar por um. A Corte constata que, de acordo com os Estados Unidos, essa prática em relação aos direitos da Convenção de Viena já está a ser seguido em algumas jurisdições locais. Case concerning Avena and other Mexican nationals (Mexico v. United States of America), ICJ Reports of Judgments, advisory opinions and orders (31/03/2004), parag. 64.
} 
lhe incumbem por força do artigo 36.1 da Convenção. Daí porque o dever de exaustão dos recursos de direito interno não se aplicaria ao caso. ${ }^{199}$

\section{b) Quanto ao pedido de interpretação e pedido urgente de nova ordem de medida provisória em caso formalmente encerrado}

Em 5 de junho de 2008, o governo do México apresentou perante a Corte da Haia, pedido de interpretação do parágrafo 153(9) da sentença AvENA de 31 de março 2004. Solicitou orientação quanto ao alcance e significado das obrigações de reparação incumbidas aos Estados Unidos, se a condenação à revisão e reconsideração, seria uma "obrigação de resultado", ou de "meio". Na mesma data, o México pediu que a Corte ordenasse Medida Provisória, até que o pedido de interpretação fosse julgado, para o fim de assegurar que José ERNESTO MEDELLín, César Roberto Fierro Reyna, Rubén Ramírez Cárdenas, Humberto Leal García, e Roberto Moreno Ramos não fossem executados. A Corte acatou o pedido do México e ordenou Medida Provisória em 16 de julho de 2008.

Foi a primeira vez que um pedido urgente de medida provisória foi apresentado perante a Corte em caso que já havia sido formalmente encerrado, dando a entender que além da interpretação, o pedido tinha a ver com a implementação da

\footnotetext{
${ }^{199}$ Em voto separado, o Juiz Vice-Presidente RANJEVA observa, referindo-se ao caso da Corte Permanente de Justiça Internacional, (Mavrommatis Parlestine Concessions, Judgment No. 2, 1924, P.C.I.J., Scries A, p. 12), que, tradicionalmente, a proteção diplomática é essencialmente uma instituição de interesse geral ou comum do direito internacional: "É um princípio elementar de direito internacional que um Estado tem o direito de proteger seus súditos, quando prejudicados por atos contrários às leis internacionais, cometidas por outro Estado, de quem eles foram incapazes de obter satisfação por meio dos canais normais. Ao assumir o caso de um dos seus sujeitos, e recorrendo à ação diplomática ou processos judiciais internacional em seu nome, o Estado está, na realidade, afirmando os seus próprios direitos - o direito de assegurar, na pessoa de seu súdito, o respeito pelas regras do direito internacional". Ele questiona a clareza da decisão da Corte sobre a questão, afirmando que à luz dos termos utilizados pela CPJI, não há uma conclusão clara: a proteção diplomática é um direito que pertence ao Estado. Assim, em matéria de proteção dos direitos individuais dos cidadãos, a questão é saber se existe um lugar para a proteção diplomática e ressalta: "Se eu tiver entendido corretamente, essas proposições (quanto à proteção diplomática) contemplam a atribuição direta de direitos individuais, mas não impõe qualquer condição prévia para Estados que pretendem invocar a violação dos direitos dos seus nacionais (como o requisito da exaustão dos recursos de direito interno)." Case concerning Avena and other Mexican nationals (Mexico $v$. United States of America), ICJ Reports of Judgments, advisory opinions and orders (31/03/2004), Declaration of Vice-President RANJEVA, pp. 76-78.
} 
decisão, o que nem a Carta das Nações Unidas e tampouco o Estatuto da Corte Internacional de Justiça prevêem.

Em 19 de janeiro 2009, no julgamento do pedido de interpretação do México, a Corte decidiu que bastava reiterar que a decisão AvENA, de 31 de março de 2004 permanecia vinculante, e que os Estados Unidos continuavam sob a obrigação de implementá-la. Ressaltou que o País violara a medida provisória ordenada em 16 de julho de 2008, ao ter executado JosÉ ERNESTO MEDELLín em 5 de agosto de 2008 sem garantir-lhe a revisão e reconsideração da condenação. Mas negou o pedido feito pelo México de ordenar garantia de não-repetição contra os Estados Unidos, eis que o País já havia se comprometido a engajar-se no cumprimento da Convenção de Viena de 1963, desde o caso LAGRAND. ${ }^{200}$

\subsection{A posição dos Estados Unidos perante o Direito Internacional, a partir da análise dos casos BREARD, LAGRAND e AVENA}

Trata-se de repetidas violações de Direito Internacional cometidas pelos Estados Unidos da América. Interessante porque, no passado, a tradição norteamericana era outra. Os tribunais estaduais e municipais, reconheciam consistentemente que tratados internacionais vinculavam o País e que, portanto, deveriam ser respeitados. Recentemente, todavia, o Executivo, o Congresso, os tribunais domésticos, e inclusive juristas passaram a afirmar que disposições de direito doméstico são a resposta final, e que o efeito vinculante dos tratados internacionais têm pouco peso. ${ }^{201} \mathrm{O}$ sistema jurídico norte americano desenvolveu

\footnotetext{
${ }^{200}$ LAGRAND (Germany $v$. United States of America), ICJ Reports of Judgments, Advisory Opinions and Orders, 27/06/2001, parág. 121-124. A Corte refere-se à publicação em janeiro de 1998 de uma brochura que seria distribuida para todas as autoridades competentes em todos os estados da Federação, e instâncias municipal, estaduial e federal, chamado: "Consular Notification and Access: Instructions for Federal, State and Local Law Enforcement and Other Officiais Regarding Foreign Nationals in the United States and the Rights of Consular Officials to Assist Them”. Além disso, distribuiu um cartão-referência e promoveu treinamentos.

${ }^{201}$ Throughout its history the United States has been a leading advocate of the judicial settlement of international disputes. Great landmarks on the road to the establishment of a really permanent international court of justice were set by the United States. As the United States becomes a party to [the U.N.] Charter it would naturally accept and use an international court to apply international law
} 
diferentes mecanismos para a recepção do direito internacional, ora com base na bem estabelecida doutrina dualista ${ }^{202}$, ora na constante necessidade de aderir a requisitos constitucionais.

Os argumentos voluntaristas alegados pelos Estados Unidos, para não cumprirem com as decisões da Corte Internacional de Justiça, suscitam o questionamento sobre a própria força do Direito Internacional frente à sua natureza horizontal e a resistência do voluntarismo. Sem falar das alegações de doutrinas de direito processual interno, como a doctrine of procedural default ${ }^{203}$, baseada na lei

and to administer justice. RUSSELL, Ruth B. A history of the United Nations Charter: the role of the United States, 1940-1945, p. 865. In: Writ of Certiorari to the Court of Criminal Appeals of Texas - Medellín v. Texas. 28 de Junho de 2007.

${ }^{202}$ Para a doutrina Monista o direito interno e o direito internacional formam um sistema jurídico único - o sistema jurídico de todos os Estados compõem um sistema jurídico único que consiste em direito interno e direito internacional. Para a doutrina dualista, o direito internacional é analisado na medida em que tenha validade no sistema jurídico nacional. Os sistemas jurídicosinterno e internacional são ordens diferentes e, portanto, operam em níveis independentes. Tratados internacionais não têm efeito no direito interno na ausência de legislação que os transforme em regras do ordenamento jurídico interno. Podem ser usados como contribuição para a fundamentação das decisões judiciais, mas não como fonte de Direito interno. FeldMAN, David. Monism, dualism and constitutional legitimacy, p. 105. O Professor PEDRO DALLARI explica que, segundo KELSEN, que tratou exaustivamente do assunto, em curso ministrado em 1926 na Academia de Direito Internacional da Haia, que versou justamente sobre "Les rapports de système entre le droit interne et le droit international public" o dualismo implica total distinção e independência entre direito interno e Direito Internacional, de sorte que a validade de uma norma interna não está condicionada à sua integração e sintonia com a ordem internacional. DALLARI, P.B. A. O Mercosul perante o sistema constitucional brasileiro, p. 41.

${ }^{203}$ US Code Collection. Title 28 (Judiciary and Judicial Procedure). Part VI (Particular Proceedings), Chapter 153 (Habeas Corpus), \$ 2254 (State custody; remedies in Federal courts): (b) (1) An application for a writ of habeas corpus on behalf of a person in custody pursuant to the judgment of a State court shall not be granted unless it appears that: $(A)$ the applicant has exhausted the remedies available in the courts of the State; or; $(B)(i)$ there is an absence of available State corrective process; or (ii) circumstances exist that render such process ineffective to protect the rights of the applicant. (2) An application for a writ of habeas corpus may be denied on the merits, notwithstanding the failure of the applicant to exhaust the remedies available in the courts of the State. (3) A State shall not be deemed to have waived the exhaustion requirement or be stopped from reliance upon the requirement unless the State, through counsel, expressly waives the requirement. (c) An applicant shall not be deemed to have exhausted the remedies available in the courts of the State, within the meaning of this section, if he has the right under the law of the State to raise, by any available procedure, the question presented." Disponível online em: < http://www.law.cornell.edu/uscode/html/uscode28/usc_sec_28_00002254----000-.html> (acesso em 24/06/2010). "Is a federal rule that, before a state criminal defendant can obtain relief in federal court, the claim must be presented to a state court. If a state defendant attempts to raise a new issue in a federal habeas corpus proceeding, the defendant can only do so by showing cause and prejudice. Cause is an external impediment that prevents a defendant from raising a claim and prejudice must be obvious on its face. One important purpose of this rule is to ensure that the state courts have an opportunity to address issues going to the validity of state convictions before the federal courts intervene." O "United States District Court for the District of Arizona" considerou que os irmãos não haviam demonstrado um fator externo objetivo que os prevenisse de alegar a violação da CVRC antes, o que foi confirmado pelo "United States Court of Appeasl Ninth Circuit". Em 02 de novembro de 1998 a Suprema Corte dos Estados Unidos negou ulterior revisão desse julgamento. LAGRAND 
Antiterrorism and Effective Death Penalty Act ${ }^{204}$. Fica difícil, senão impossível, para os governos estrangeiros e seus nacionais processarem os estados norte-americanos em um tribunal federal em face do descumprimento da Convenção de Viena de 1963, porque essas alegações esbarrariam na Emenda XI da Constituição do país que, na maioria das circunstâncias, fornece aos estados imunidade judicial soberana em um tribunal federal, contra litígios apresentadas por indivíduos estrangeiros e por outros países. ${ }^{205}$ Para JANICE JACOBS L. ${ }^{206}$, Secretário de Estado Assistente para Assuntos Consulares, a consequência mais significativa dessas violações, entretanto, é que os Estados Unidos serão vistos como um país que não leva suas obrigações jurídicas internacionais a sério.

Sobre a posição dos Estados Unidos perante o direito internacional, nas palavras do Professor JACOB DOLINGER, lembrando alguns clássicos em que a Suprema Corte respeitou os direitos de outras soberanias e os princípios gerais do direito, "a tradição era boa" ${ }^{207}$ Ele menciona o caso do PAQUETE HABANA ${ }^{208}$, um dos mais citados na jurisprudência de direito internacional norte americana, em que a Suprema Corte decidiu, em 08 de janeiro de 1900, pela exclusão de barcos

(Germany $v$. United States of America), ICJ Reports of Judgments, Advisory Opinions and Orders, 27/06/2001, parág, 23.

${ }^{204}(\ldots)$ which provides that a habeas petitioner alleging that he is held in violation of "treaties of the United States" will, as a general rule, not be afforded an evidentiary hearing if he "has failed to develop the factual basis of [the] claim in State court proceedings." 28 U.S. C. A. \$\$ 2254(a), (e)(2) (Supp. 1998). Breard v. Greene, 523, 371, U.S, (14/04/1998) Supreme Court of the United States.

${ }^{205}$ Esta alteração foi aprovada em resposta a, e a fim de sobrepor, a decisão da Suprema Corte sobre o caso Chisholm v. Georgia, 2 U.S. 419 (1793). O texto da XI Emenda é o seguinte: "The Judicial power of the United States shall not be construed to extend to any suit in law or equity, commenced or prosecuted against one of the United States by Citizens of another State, or by Citizens or Subjects of any Foreign State."

${ }^{206}$ Consular notification of detained foreign nationals. A letter to the law enforcement community from the Assistant Secretary of State for Consular Affairs. 28/04/2010. Disponível online em: <http://www.policeone.com/border-patrol/articles/2072444-Consular-notification-ofdetained-foreign-nationals/> (acesso em 02/04/2011).

${ }^{207}$ DOLINGER, Jacob. Os Estados Unidos perante o Direito Internacional. A decadência jurídica de uma grande nação, p. 84 e ss. O Professor menciona o primeiro caso que se tem notícia na jurisprudência norte americana, The Schooner Exchange v. Mc Faddon, julgado em 1812, em que se concedeu plena imunidade ao Imperador da França e Rei da Itália, Napoleão Bonaparte, em ação movida por dois americanos que pleiteavam a propriedade de um navio de guerra que entrara no porto de Philadelfia, devido ao mau tempo. A Suprema Corte fundamentou sua decisão mencionando Ulrich Ulber e o Tratado de Bynkershoek, assim como na autoridade de Vattel, para não submetê-lo à jurisdição norte americana. O Professor destacou ainda outros clássicos, como Whitney v. Robertson, de 1888, sobre a hierarquia dos tratados internacionais, que, conforme a Constituição norte americana tem mesma posição hierárquica do que uma lei, ambos declarados como sendo a supreme law of the land e, ocorrendo conflito, prevalece a última palavra do Congresso.

${ }^{208}$ U.S. Supreme Court - The Paquete Habana, 175 U.S. 677 (1900). 
pesqueiros, Paquete e Habana, pertencentes a cidadãos espanhóis, nascidos e domiciliados em Cuba de apreensão como presas de guerra, consagrando a força do direito costumeiro e a autoridade da opinião dos jurisconsultos, sobre a força cogente da doutrina que isenta os pesqueiros, seus barcos e cargas de captura como presas de guerra. Em sua decisão, a Suprema Corte historia a matéria desde as ordens emitidas pelos reis ingleses do século $\mathrm{XV}$, até a tradição norte americana de respeito ao direito dos pescadores, referindo-se à guerra com o México em 1846, quando reconheceram a imunidade à apreensão de barcos que faziam pesca costeira. ${ }^{209}$

Hoje, no entanto, o "Dualismo" parece prevalecer para a relação entre Direito Internacional e o doméstico, apesar das críticas à doutrina por muitos acadêmicos. Os Estados Unidos podem representar o exemplo essencial da abordagem dualista, que considera que o Direito Internacional e o interno são regimes com planos distintos. O Direito doméstico se aplica na esfera internacional apenas se os atores internacionais decidirem incorporá-lo e, inversamente, o Direito Internacional é aplicável na esfera doméstica somente se os atores internos decidirem incorporá-lo. ${ }^{210}$

Fazendo-se uma alusão com ao caso Arrest Warrant of $11^{\text {th }}$ April 2000 (Democratic Republic of the Congo v. Belgium) ${ }^{211}$, em que a Corte Internacional de Justiça ordenou o cancelamento da prisão do Ministro das Relações Exteriores do Congo pelas autoridades belgas, a legalidade da prisão do Ministro era em si a violação do Direito Internacional, com respeito à imunidade diplomática. No

\footnotetext{
${ }^{209}$ O Professor DOLINGER ressalta trechos do julgamento que deixam bem claro a posição da Suprema Corte sobre o direito internacional naquele caso: "International law is part of our law, and must be ascertained and administered by the courts of justice of appropriate jurisdiction as often as questions of right depending upon it are duly presented for their determination. For this purpose, where there is no treaty and no controlling executive or legislative act or judicial decision, resort must be had to the customs and usages of civilized nations, and, as evidence of these, to the works of jurists and commentators who by years of labor, research, and experience have made themselves peculiarly well acquainted with the subjects of which they treat. Such works are resorted to by judicial tribunals, not for the speculations of their authors concerning what the law ought to be, but for trustworthy evidence of what the law really is."DOLINGER, Jacob. Os Estados Unidos perante o Direito Internacional. A decadência jurídica de uma grande nação, p. 87.

${ }^{210}$ MURPHY, John F., Medellín v. Texas: implications of the Supreme Court's decision for the United States and the rule of law in international affairs... pp. 251-252. Disponível online em: $<$ http://www.law.suffolk.edu/highlights/stuorgs/transnat/documents/Murphy.pdf> (acesso em 21/06/2009)

${ }^{211}$ Case concerning the Arrest Warrant of $11^{\text {th }}$ April 2000 (Democratic Republic of the Congo v. Belgium), ICJ Judgement Report, $14^{\text {th }}$ February 2002.
} 
presente caso não são as sentenças e condenações em si que estão em violação com o Direito Internacional, mas o simples fato de terem sido aplicadas sem o cumprimento da obrigação internacional nos termos do art. 36 da Convenção de Viena sobre Relações Consulares de 1963. Daí porque a escolha do meio da revisão e reconsideração deve ser tomada pelos Estados Unidos e seu sistema judiciário, no sentido de fazer cumprir com o direito de informação sobre assistência consular, ou seja, cumprir com a obrigação perante os indivíduos e perante o México. ${ }^{212}$

ADRIENNE TRANEL acredita que a Corte Internacional de Justiça acertou ao negar a institutio in intengrum, ordenando os Estados Unidos a revisarem e reconsiderarem as condenações à pena capital em violação ao art. 36 da Convenção de Viena de 1963. Mas, apesar de a Corte ter providenciado uma definição mais precisa para o que seria "revisão e reconsideração" de uma sentença condenatória, poderia ter emitido uma ordem de garantia de não-repetição contra os Estados Unidos. ${ }^{213}$ Se bem que seria impossível a restitutio in integrum, ou seja, o retorno ao status quo ante, uma vez que o paraguaio ANGEL FrANCISCO BREARD, o alemão WALter LAGRAND e o mexicano José ERNesto Medellín foram executados, à margem das ordens de medidas provisionais e sentenças da Corte Internacional de Justiça.

O governo norte americano também questionou a natureza das formas de reparação "cessação do ilícito" e "garantia de não-repetição", basicamente porque exigir atos específicos pelos Estados Unidos em seus sistemas judiciais penais domésticos penetraria profundamente na independência do sistema estadual e federal de justiça criminal. Alegaram que a Corte não teria competência para isso, o que

\footnotetext{
212 "The present case has clearly to be distinguished from the Arrest Warrant case. In that case, the question of the legality under international law of the act of issuing the arrest warrant against the Congolese Minister for Foreign Affairs by the Belgian judicial authorities was itself the subjectmatter of the dispute. Since the Court found that act to be in violation of international law relating to immunity, the proper legal consequence was for the Court to order the cancellation of the arrest warrant in question (I.C.J. Reports 2002, p. 33). By contrast, in the present case it is not the convictions and sentences of the Mexican nationals which are to be regarded as a violation of international law, but solely certain breaches of treaty obligations which preceded them". Case concerning Avena and other Mexican nationals (Mexico v. United States of America), ICJ Reports, March 31 ${ }^{\text {st }}$ 2004, parág. 123.

${ }^{213}$ Tranel, Adrienne M. The Ruling of the International Court of Justice in Avena and other Mexican Nationals, p. 407.
} 
seria uma "intromissão" na autonomia do sistema jurídico-criminal da Federação. ${ }^{214}$ Que a Corte estaria agindo como se fosse um "Tribunal Internacional de Apelação Criminal". Além disso, a Convenção de Viena não criaria direito que um indivíduo estrangeiro condenado pudesse arguir em procedimentos criminais domésticos. ${ }^{215}$

Acontece que não há sombra de subordinação de um órgão judicial nacional a outro internacional, mesmo quando o ato tido como violador de direitos humanos é uma decisão judicial interna. Um tribunal internacional tem natureza jurídica de Direito Internacional, só se relaciona com sujeitos de Direito Internacional. Não existe hierarquia funcional entre o tribunal internacional e um de direito interno. As partes, o conteúdo e o conteúdo da controvérsia não são iguais nas duas jurisdições. No tribunal internacional discute-se a pretensa violação de obrigação de direito internacional cometida pelo Estado. Daí porque a instância internacional não é um tribunal superior ao interno, de apelação ou cassação, mas é órgão internacional que constata a responsabilidade internacional do Estado por violação de obrigação de Direito Internacional assumida. Uma decisão judicial interna que viola o Direito Internacional é vista pelos tribunais internacionais como mero fato. As instâncias internacionais não rescindem nem reformam ato judicial interno, mas constatam a violação da obrigação de direito internacional, e o resultado disso é a suspensão dos efeitos do ato judicial interno. ${ }^{216}$

\footnotetext{
214 "The United States objects that so to require specific acts by the United States in its municipal criminal justice systems would intrude deeply into the independence of its courts; and that for the Court to declare that the United States is under a specific obligation to vacate convictions and sentences would be beyond its jurisdiction. The Court, the United States claims, has no jurisdiction to review appropriateness of sentences in criminal cases, and even less to determine guilt or innocence, matters which only a court of criminal appeal could go into." Case concerning Avena and other Mexican nationals (Mexico $v$. United States of America), ICJ Reports, March 31 ${ }^{\text {st }}$ 2004, parág. 32.

${ }^{215}$ A International Law Comission desde 1979 refere que é fato inegável que, em nível de direito internacional, qualquer distinção é feita entre um Estado com estrutura unitária e um Estado Federado no sentido de isenção de responsabilidade internacional. The International Law Commission's Draft Articles on State responsibility. Yearbook of the International Law Commission. Vol. II, Part I. United Nations Publication, 1979. Sobre a imagem do País diante do não-comprometimento com suas obrigações internacionais, destacamos o que Alexander Hamilton bem asseverou, criticando o sistema de federação, em 1787 "The faith, the reputation, the peace of the whole Union, are thus continually at the mercy of the prejudices, the passions, and the interests of every member of which it is composed. Is it possible that foreign nations can either respect or confide in such a government? Is it possible that the people of America will longer consent to trust their honor, their happiness, their safety, on so precarious a foundation?" In: HAMILTON, Alexander. The Federalist, $\mathrm{n}^{\circ} .22$

${ }^{216}$ RAmos, André de Carvalho. Processo internacional de direitos humanos, pp. 345 e 354-358. E Direitos humanos em juízo, pp. 509-510.
} 
SARAH M. RAY ${ }^{217}$ acredita ser provável que a Corte Internacional de Justiça alegue que a condenação nos casos LAGRAND e AvENA possam gerar um mal entendido sobre o que entende por "revisão e reconsideração", como reparação por violações cometidas contra o artigo 36 da Convenção de Viena sobre Relações Consulares de 1963. Em nenhum lugar na decisão do caso LaGrand a Corte exigiu "um exercício de julgamento." A decisão apenas indicou como necessárias duas coisas: "revisão e reconsideração" das condenações em violação ao Direito Internacional. Geralmente, o uso de duas palavras com significados diferentes implica duas exigências distintas e separáveis. Seguindo esse raciocínio, "revisar" exige o exame completo do registro para determinar a existência de violações contra Convenção de Viena de 1963, e as circunstâncias em que ocorreram. Se essa revisão localiza uma violação, então o segundo aspecto do remédio, "reconsideração", entraria em vigor, exige que o ato seja repetido ou reavaliado após a descoberta da violação.

O remédio pode exigir inúmeras ações, como a supressão de uma confissão, porque um consulado teria explicado ao réu o direito de permanecer em silêncio; um novo julgamento, porque o primeiro julgamento foi realizado sem a defesa efetivo e o consulado teria fornecido um advogado melhor; ou uma nova audiência de sentença, porque o primeiro não tinha provas atenuantes, e o consulado poderia ter fornecido informações e testemunhas do país de origem do réu. Para SARAH M. RAY, o órgão competente para resolver como reconsiderar e revisar as condenações à margem do Direito Internacional e para implementar as obrigações internacionais assumidas pelos Estados Unidos é a Suprema Corte.

Considerou-se irrelevante o Memorando emitido pelo Presidente GeOrge W. Bush ${ }^{218}$ em 28 de fevereiro de 2005, que concordou em dar

\footnotetext{
${ }^{217}$ RAY,Sarah M., Domesticating International Obligations: How to Ensure U.S. Compliance with the Vienna Convention on Consular Relations, pp. 1764-1766.

${ }^{218}$ O Presidente BUSH fez a seguinte declaração ao Advogado Geral: "I have determined, pursuant to the authority vested in me as President by the Constitution and the laws of the United States of America, that the United States will discharge its inter-national obligations under the decision of the International Court of Justice in the Case Concerning Avena and Other Mexican Nationals (Mexico v. United States of America) (Avena), 2004 ICJ 128 (Mar. 31), by having State courts give effect to the decision in accordance with general principles of comity in cases filed by the 51 Mexican nationals addressed in that decision. [Signed] George W. Bush."
} 
cumprimento à decisão da Corte, referente ao caso AvenA. A Suprema Corte considerou que ele não teria autoridade baseada em lei federal para essa determinação, o que seria um ato inconstitucional. A Suprema Corte concluiu que nem a sentença AvENA, da Corte Internacional de Justiça, e tampouco o Memorando expedido pelo Presidente George W. BuSH constituem diretamente "directly enforceable federal Law". ${ }^{219}$

Isso parece não coincidir com os termos da própria Constituição norteamericana, que se destaca por ser um documento com mais de duzentos anos de existência, e a referência a tratados internacionais é expressa. Prevê que o Congresso tem o poder para declarar como ilegais as violações de Direito Internacional, mas não há qualquer disposição sobre a recepção de sentenças internacionais pelo ordenamento jurídico interno. A seção II do artigo II da Constituição americana dispõe sobre o poder de celebrar tratados exercido pelo Presidente, "com o conselho e consentimento do Congresso, desde que dois terços dos Senadores presentes concordem". Além disso, o Congresso utiliza os seus poderes para implementar os tratados que não são auto-executáveis, isto é, na ausência de legislação de execução. ${ }^{220}$ Pela leitura do artigo VI, seção II, da Constituição norte americana, as

${ }^{219}$ Medellin v. Texas - Certiorari to the Court of Criminal Appeals of Texas No. 06-984. Argued October 10, 2007-Decided March 25, 2008, p. 02. O Professor ROSENKRANZ propõe um texto para a lei que implementaria a CVRC, a ser legislada pelo Congresso, o Avena Act, que teria o seguinte teor: "(a) No state or locality therein shall receive Justice Assistance Grant funding, unless that state satisfies the conditions set forth in parts $(b)$ and $(c)$ of this section. This section does not bind a state that refuses receipt of funds. (b) The state shall direct its agents to read the consular notification rights set forth in the Vienna Convention on Consular Notification, upon the arrest of an alien or realization that a person in state custody is an alien; the state shall then notify the nearest consulate of the alien's home country and allow a representative of that consulate to consult with the alien upon request. (c) In the event that an alien is detained for forty-eight hours or more before receiving the notification required by part (b) of this section, or if credible evidence is presented that state officials knew of the alien's status and deliberately delayed in informing him or her of his or her rights under the Vienna Convention, then the state must provide for a hearing to determine if prejudice occurred regardless of when the alien raises this claim and irrespective of state procedural default rules.(d) The Anti-Terrorism and Effective Death Penalty Act shall not be construed as precluding the hearing required by part (c) of this section.(e) This section shall not be construed as preventing states or localities from providing additional remedies than those provided in this section." DUFFY, Edward . The Avena Act: An Option To Induce State Implementation of Consular Notification Rights After Medellín. Disponível online em: < http://legalworkshop.org/2010/09/13/the-avena-act-anoption-to-induce-state-implementation-of-consular-notification-rights-after-medellin> (acesso em 06/12/2010).

${ }^{220}$ No caso Missouri, O Justice Holmes declarou que o governo federal poderia implementar tratados não auto-executáveis mesmo na ausência de lei federal implementatória criada pelo o Congresso, e mesmo se o Congresso não pudesse editar lei federal com o mesmo teor, na ausência do tratado. State of Missouri vs. Holland, 252 U.S. 416 (1920), 252 U.S. 416. 
cortes estaduais e federais devem executar tratados justamente com hierarquia de leis federais em casos de suas respectivas jurisdições.

A "supremacy clause" declara em seu artigo VI seção 2 da Constituição $^{221}$, que, além da Constituição e as leis, os tratados firmados pelos Estados Unidos deverão ser considerados a "Lei suprema da terra" (supreme law of the Land" ${ }^{, 22}$ ). Isto é, depois que um tratado é ratificado, de acordo com a Constituição, a "supremacy clause" lhe confere igual status de lei federal suprema. ${ }^{223}$

221 "Article VI - This Constitution, and the Laws of the United States which shall be made in Pursuance thereof; and all Treaties made, or which shall be made, under the Authority of the United States, shall be the supreme Law of the Land; and the Judges in every State shall be bound thereby, anything in the Constitution or Laws of any State to the Contrary notwithstanding."

222 Além do reconhecimento de que a Cláusula de Supremacia assegurou a superioridade dos tratados sobre o direito estatal e confirmou que algumas disposições dos tratados seriam executáveis em tribunais internos, existe uma brecha na Constituição americana quanto aos detalhes da implementação do tratado a ser trabalhado ao longo do tempo. A doutrina da auto-execução tem fundamentos ambíguos e levou tempo para surgir dos primeiros debates políticos, e precisa ser revista de tempos em tempos. Em 1829 a Suprema Corte respondeu parcialmente sobre o conflito entre leis federais e tratados internacionais, quando anunciou no caso Foster v. Neilson que tratados internacionais possuem duas categorias para propósitos judiciais: Tratados contendo status de lei judicialmente implementável são considerados "auto-executáveis", ou seja, não precisam de legislação posterior para que possam operar internamente: "Our constitution declares a treaty to be the law of the land. It is, consequently, to be regarded in courts of justice as equivalent to an act of the legislature, whenever it operates of itself without the aid of any legislative provision. But when the terms of the stipulation import a contract, when either of the parties engages to perform a particular act, the treaty addresses itself to the political, not the judicial department; and the legislature must execute the contract before it can become a rule for the Court." 27 U.S. (2 Pet.) 253, 314 (1829). Primeiro, alguns tratados são auto-executáveis (os que criam direitos individuais e vestem com poder o Executivo), o que significa que vestem poder diretamente pelo Presidente, sendo obrigatórios em tribunais internos sem legislação implementatória posterior. Em segundo lugar, outros tratados não são auto-executáveis porque exigem a aplicação da legislação para produzir efeitos jurídicos nacionais. Em terceiro lugar, os conflitos entre tratados e leis federais serão resolvidos pela regra last in time rule, a qual reconhece que os tratados não precisam aplicação da legislação simplesmente porque entram em conflito com leis federais, mas também reconhece a autoridade do Congresso sobre as matérias reguladas pelos tratados, e rejeita a idéia de que os tratados são superiores aos estatutos federais. Pela leitura tanto da cláusula do tratado e da cláusula da supremacia dão ao Presidente e ao Senado o poder de celebrar tratados, que será a lei suprema da terra, aparentemente em pé de igualdade com a Constituição e leis federais, ao dizer nada sobre o papel da Câmara na celebração de tratados. Cada estado americano adotou o texto da Constituição como está escrita. Embora o poder do tratado e Cláusula de Supremacia eram controversos, e as emendas foram propostas, não foram introduzidas alterações ao documento. No entanto, os federalistas fizeram declarações tão ambíguas sobre os tratados que o fracasso final para aprovar uma emenda não pode ser conclusivo. Federalistas conquistaram a vitória importante de começar a Constituição ratificada, mas sua vitória foi tão clara sobre as questões igualmente importantes do que isso significaria na prática. Na verdade, a idéia de que o significado da Constituição deve emergir do diálogo entre federalistas e antifederalistas teve ressonância muito além do debate sobre os tratados e se tornou uma parte importante do realinhamento da política americana, que começou no final de 1790. O conflito entre um tratado celebrado em 1783, a Cláusula de Supremacia, e lei estadual chegou à Suprema Corte em 1796, no caso Ware v. Hylton. Um credor britânico processou o devedor do estado da Virgínia no tribunal federal do circuito, buscando o pagamento de uma dívida de 1774. O devedor argumentou que a dívida havia sido parcialmente quitada em conformidade com o uma lei da Virgínia que permitiu devedores para pagar parte ou a totalidade da dívida ao Estado e receber uma quitação enquanto o 
Em outras palavras, a Constituição dos Estados Unidos estabelece que os tratados vinculam a Nação como um todo, e não refere a aberta possibilidade de

credor afirmou que o tratado de paz de 1783 revogou o estatuto da Virgínia e anulou todos os processo sob ele. O tribunal concordou com o com o devedor. A Suprema Corte reverteu a decisão. Sobre o impacto do tratado no direito do estado da Virginia o Justice Chase declarou que o tratado possuia hierarquia superior. Mesmo se houvesse dúvidas sobre essa questão, a Cláusula de Supremacia da Constituição resolveu a questão: "Um tratado não pode ser a lei suprema do país, que é de todos os Estados Unidos, se qualquer ato legislativo de um estado da Federação pode ficar no seu caminho. Ele passou a enfatizar a natureza abrangente da Cláusula de Supremacia "da mesma forma que um tratado pode revogar uma lei do estado, também pode anulá-lo"O resultado foi que o tratado de 1783 não se limitou o estatuto de seqüestro daVirginia, mas também com efeitos retroactivos foram anulados todos os atos tomados com base nela que eram incompatíveis com o Tratado de Paz de 1783. No caso, Ware afirmou que a Cláusula de Supremacia faz das disposições de alguns tratados autoexecutáveis sem necessidade de legislação posterir, mas os Justices Chase e Iredell fizeram uma clara distinção entre os tipos de disposições de tratados, e Chase também afirmou que algumas disposições do Tratado exigem a implementação pelo Congresso ou do Presidente, e não poderia ser implementados diretamente pelos tribunais. Além disso, a Suprema Corte aplicou o tratado a substituir a lei estadual, mas não chegou a discutir o impacto dos tratados sobre leis federais. Também não discutir o papel da Câmara dos Deputados na implementação do tratado além de reconhecer que a legislação federal, às vezes, é necessária. A partir de 1796, uma série de questões de política externa levou os membros do Congresso em extensos debates sobre o lugar dos tratados na ordem constitucional americana, especialmente na separação do nível de competências, até que a Suprema Corte, no caso Foster v. Neilson adotou a regra "last in time" No mesmo ano, Alexander Hamilton foi muito claro sobre o impacto de um tratado sobre os estatutos federais. Para ele pela Constituição americana, que garante ipso facto aos tratados, tornando-os em igualdade com atos do Congresso, a lei suprema do país, um Tratado deve, necessariamente, revogar uma lei antecedente ao contrário, de acordo com o princípio jurídico de que 'leges contrarias priores abrogant posteriores. Hamilton defendeu que o poder do tratado e da cláusula de supremacia criam uma catraca de sentido único. Tratados podem substituir a legislação anterior contrária e vincular o Congresso a aplicá-los ou apoiálos quando necessário. Eles também retiram o Congresso de seu poder legislativo sobre questões já cobertas por tratados. Hamilton ainda insistiu estas conclusões eram consistentes com as intenções dos autores e os entendimentos do ratificadores. Os Republicanos descartavam a idéia de que os tratados poderiam substituir estatutos federais existentes. A Cláusula de Supremacia, eles notaram, foi dirigida para os estados e nada disse sobre a prioridade relativa das diferentes fontes de leis federais. $\mathrm{Na}$ verdade, eles sugeriram a sua reivindicação de autoridade da Câmara, evitado o argumento da Cláusula de Supremacia, porque os tratados precisariam de sanção legislativa, o que eliminaria a maioria dos conflitos entre tratados e leis. Quanto aos debates de ratificação, os Republicanos se baseavam nos argumentos de conciliação em vários estados pelos proponentes da constituição que conflitavam com os federalistas (que defendiam que tratados poderiam revogar leis federais, mas essas não poderiam revogar os tratados). Em 1822, Thomas Sargeant declarou: "como o tratado é declarado ser a lei suprema do da terra, é obrigatório sobre os tribunais, e quando afeta os direitos das partes em litígio na Justiça, é para ser considerada um ato do Congresso". Ware v. Hylton, 3 U.S. (3 Dall.) 199 (1796) e Foster v. Neilson, 27 U.S. (2 Pet.) 253 (1829). PARRY, John T., Congress, the Supremacy Clause, and the Implementation of Treaties, pp. 1265-1275.

${ }^{223}$ Ainda que os tratados internacionais possuam a mesma força jurídica que as leis federais, ainda não são do mesmo caráter: These gentlemen would do well to reflect that a treaty is only another name for a bargain, and that it would be impossible to find a nation who would make any bargain with us, which should be binding on them absolutely, but on us only so long and so far as we may think proper to be bound by it. They who make laws may, without doubt, amend or repeal them; and it will not be disputed that they who make treaties may alter or cancel them; but still let us not forget that treaties are made, not by only one of the contracting parties, but by both; and consequently, that as the consent of both was essential to their formation at first, so must it ever afterwards be to alter or cancel them. The proposed Constitution, therefore, has not in the least extended the obligation of treaties. They are just as binding, and just as far beyond the lawful reach of legislative acts now, as they will be at any future period, or under any form of government. JAY, John. The Powers of the Senate. Independent Journal. The Federalist. No. 64. Wednesday, March 5, 1788. Disponível online em: <http://www.constitution.org/fed/federa64.htm> (acesso em 02/02/2010). 
políticas inconsistentes dos estados individualmente. ${ }^{224}$ PEDRO DALLARI ${ }^{225}$ observa que não há referência explícita sobre a eventual superioridade da norma convencional internacional em relação às do ordenamento jurídico interno, mas que a Constituição contempla expressamente a respeito da integração do tratado ao ordenamento jurídico nacional.

Daí saber se a "Lei suprema da terra" tem a ver com a obrigação do país de cumprir as decisões da Corte Internacional de Justiça. O fato é que ao não respeitarem a Convenção de Viena sobre Relações Consulares de 1963 e ignorarem as ordens de medidas provisórias e sentenças da Corte Internacional de Justiça, alegando todos os obstáculos de direito doméstico possíveis, além da não autoexecutabilidade da Convenção de Viena, os Estados Unidos cometeram graves violações de Direito Internacional. ${ }^{226}$

No julgamento do último habeas corpus interposto em favor de JosÉ ERNESTO MEDELLÍN ${ }^{227}$, BREYer foi acompanhado pelos Justices SOUTER e GINSBURG $^{228}$, em voto concorrente. Em nome da supreme clause da Constituição, BREYER alegou que as cortes internas devem obedecer a um tratado. Explicaram que os Estados Unidos assinaram e ratificaram uma série de tratados obrigando os a cumprir com as decisões da Corte Internacional de Justiça em casos em que tenha

\footnotetext{
${ }^{224}$ De acordo com JAMES WILSON, no decorrer dos debates sobre a ratificação da Constituição, na Pensilvânia: This clause, sir, will show the world that we make the faith of treaties a constitutional part of the character of the United States; that we secure its performance no longer nominally, for the judges of the United States will be enabled to carry it into effect, let the legislatures of the different states do what they may. Disponível online em: <http://www.constitution.org/rc/rat_pa.htm> (acesso em 19/06/2009).

${ }^{225}$ DALlARI, Pedro B. A. Constituição e Tratados Internacionais, p. 27.

${ }^{226}$ Uma questão importante e sem solução legal é saber se a CVRCcria uma causa de ação de tal forma que uma a possibilitar o ajuizamento de uma ação judicial em um tribunal nos Estados Unidos para impor o tratado. Primeiro é preciso saber se a CVRC é auto-executável. Só então poderia o tratado de dar origem a uma causa de ação para fazer valer os direitos que podem ser concedidos por esse tratado. Sob o Direito dos EUA, um tratado auto-executável é aquele diretamente aplicável nos tribunais dos EUA, sem a necessidade de implementação da legislação por meio de lei federal emitida pelo Congresso. BUYS, Cindy Galway. Strangers in a Strange Land: The Importance of Better Compliance with Consular Notification Rights, p. 23

${ }^{227}$ Medellin v. Texas. Certiorari to the Court of Criminal Appeals of Texas. No. 06-984. Argued October 10, 2007-Decided March 25, 2008. Somente se o tratado contiver estipulações autoexecutáveis que não será necessário uma lei posterior para implementá-lo internamente, possuindo a força e efeito de lei federal. O texto do tratado é crucial, e seus termos podem refletir uma determinação do Presidente que o negocia, e do Senado que confirma que o tratado possui efeitos domésticos.

${ }^{228}$ Medellin v. Texas - Certiorari to the Court of Criminal Appeals of Texas No. 06-984. Argued October 10, 2007-Decided March 25, 2008, pp 50-52.
} 
dado o seu consentimento para o exercício da sua autoridade adjudicatória, como o Protocolo Opcional à Convenção (Optional Protocol, Art. I, Apr. 24, 1963, [1970]

21 U. S. T. 325, 326 T. I. A. S. No. 6820 - capitalization altered), e concordaram com a força vinculante das decisões da Corte Internacional de Justiça, no âmbito dos tribunais internos.

Muito importante a observação desses Justices sobre a interpretação do teor do artigo 94 da Carta das Nações Unidas ${ }^{229}$, que estabelece que cada Nação signatária "se compromete a cumprir as decisões da Corte Internacional de Justiça, em qualquer caso a que seja parte". ${ }^{230} \mathrm{O}$ artigo 59 do Estatuto da Corte Internacional Justiça estabelece que "a decisão da Corte não é obrigatória senão para as partes em litígio e respeito ao caso alvo de decisão". O artigo 60 prevê que "a sentença será definitiva e inapelável. Em caso de desacordo sobre o sentido ou desfecho da sentença, a Corte interpretará a solicitação de qualquer das partes". ${ }^{231}$

\footnotetext{
${ }^{229}$ A aplicação do art. 94 da Carta da ONU fora discutido pelos tribunais americanos. No caso, o United States Court of Appeals for the District of Columbia Circuit recusou-se a dar efeito ao artigo, usando doutrinas de direito interno sobre implementação de tratados. O caso envolvia organizações e indivíduos que alegavam prejuízos físicos e econômicos sofridos em guerra na Nicarágua, contrários à política imposta pelos EUA na América central. O tribunal alegou que o art. 94 da Carta da ONU não seria auto-executável, e tampouco conferiria direitos a indivíduos. Deixou em aberto, portanto, quando a parte a pedir a implementação de uma decisão da Corte Internacional de Justiça é um Estado. "Neither individuals nor organizations have a cause of action in an American court to enforce ICJ judgments. The ICJ is a creation of national governments, working through the U.N.; its decisions operate between and among such governments and are not enforceable by individuals having no relation to the claim that the ICJ has adjudicated -in this case, a claim brought by the government of Nicaragua. Appellants try to sidestep this difficulty by alleging violations of international law rather than styling their suit as an enforcement action in support of the ICJ judgment. The United States' contravention of an ICJ judgment may well violate principles of international law. But, as we demonstrate below, those violations are no more subject to challenge by private parties in this court than is the underlying contravention of the ICJ judgment.United States Court of Appeals for the District of Columbia Circuit. No. 87-5053. Argued November 13, 1987. Decided October 14, 1988.Committee of United States Citizens Living in Nicaragua et al Appellants, v. Ronald Wilson Reagan, President of the United States, et al, Appellee. Antes disso, um pedido de abertura de contencioso internacional havia sido interposto pela Nicarágua contra os EUA perante a Corte, alegando que o apoio militar oferecido pelos EUA aos Contras, contra o governo da Nicarágua, violava o direito internacional costumeiro e tratado internacional entre os países. A Corte julgou favoravelmente à Nicarágua.

${ }^{230}$ Existe uma lei emitida pelo Congresso que reforça a obrigação dos EUA sob à Carta da ONU, o United Nations Participation Act (1945): prescribe the domestic, internal arrangements within [the U.S.] Government for giving effect to [U.S.] participation in [the United Nations] and [to] set up the machinery whereby [U.S.] national authorities can comply with certain of the major international commitments" assumed by the United States upon its ratification of the U.N. Charter. These commitments included the requirement that U.N. members comply in good faith with any Security Council decision under Article 41 to apply specified measures short of the use of armed force to implement Security Council decisions."

${ }^{231}$ Medellin v. Texas - Certiorari to the Court of Criminal Appeals of Texas No. 06-984. Argued October 10, 2007-Decided March 25, 2008, p. 52.
} 
BREYER asseverou que o tratado que consagra a Corte Internacional de Justiça, a Carta das Nações Unidas, é auto-executável, baseando-se na leitura de outros tratados, que tiveram efeito sem uma ação adicional do Congresso. Para ele, o julgamento de AvENA seria auto-executável, pelo fato de os Estados Unidos terem consentido e ratificado à jurisdição da Corte, o que vincula o País sem a necessidade de outra lei interna. ${ }^{232}$ Ele citou 29 casos $^{233}$, retrocedendo 200 anos na história, em que a própria Suprema Corte, haja vista a supremacy clause, considerou tratados internacionais como "self-executing", por exemplo, o caso Ware v. Hylton 3 U.S. 3 Dall. 199199 (1796), que ilustrou que os tratados internacionais "devem ser a lei

\footnotetext{
${ }^{232}$ Mesmo se toda a Convenção de Viena não seja considerada auto-executável, é possível para os tribunais determinarem que disposições selecionadas, como os artigos 36 e 37 da referida Convenção, são auto-executáveis. Por exemplo, no caso Sei Fujii, a Suprema Corte da Califórnia declarou que algumas das disposições da Carta das Nações Unidas pode seriam auto-executáveis, mesmo que as disposições específicas invocadas pelo demandante, nesse caso não fossem. Para determinar se um tratado é auto-executável os tribunais olham para a intenção das partes signatárias, manifestada pela linguagem do instrumento, e, se o instrumento é incerto, se pode recorrer para as circunstâncias que rodearam a sua execução. "In determining whether a treaty is self-executing, courts look to the intent of the signatory parties as manifested by the language of the instrument, and, if the instrument is uncertain, recourse may be had to circumstances surrounding its execution. (...) If that treaty language is "clear and definite or prescribed in detail the rules governing rights and obligations of individuals, it is likely that the framers intended for that treaty provision to be self-executing." Fujii v. California (Supreme Court of California L. A. No. 21149 1952.CA.40786 ; 242 P.2d 617; 38 Cal. 2d 718, April 17, 1952, Sei Fujii, Appellant, v. The State of California, Respondent. Appeal from a judgment of the Superior Court of Los Angeles County. Wilbur C. Curtis, Judge.

${ }^{233}$ Georgia v. Brailsford, 3 Dall. 1, 4 (1794); Hopkirk v. Bell, 3 Cranch 454, 457-458 (1806); Hannay v. Eve, 3 Cranch 242, 248 (1806) (monetary debts); Martin v. Hunter's Lessee, 1 Wheat. 304, 356-357 (1816) (land ownership); Chirac v. Lessee of Chirac, 2 Wheat. 259, 270-271, 274, 275 (1817) (land ownership and inheritance); Orr v. Hodgson, 4 Wheat. 453, $462-465$ (1819); United States v. Arredondo, 6 Pet. 691, 697, 749 (1832); United States v. Percheman, 7 Pet. 51, 88-89 (1833) (land ownership); American Ins. Co. v. 356 Bales of Cotton, 1 Pet. 511, 542 (1828) (property); Hauenstein v. Lynham, 100 U. S. 483, 485-486, 490-491 (1880) (property rights and inheritance); United States v. Rauscher, 119 U. S. 407, 410-411, 429-430 (1886) (extradition); Wildenhus's Case, 120 U. S. 1, 11, 17-18 (1887) (criminal jurisdiction); Geofroy v. Riggs, 133 U. S. 258, 267-268, 273 (1890) (inheritance); Johnson v. Browne, 205 U. S. 309, 317-322 (1907) (extradition); Asakura v. Seattle, 265 U. S. 332, 340, 343-344 (1924) (same); Maiorano v. Baltimore \& Ohio R. Co., 213 U. S. 268, 273-274 (1909) (travel, trade, access to courts); Olympic Airways v. Husain, 540 U. S. 644, 649; 657 (2004) (air carrier liability); El Al Israel Airlines, Ltd. v. Tsui Yuan Tseng, 525 U. S. 155, 161163, 176 (1999) (same); Zicherman v. Korean Air Lines Co., 516 U. S. 217, 221, 231 (1996); Société Nationale Industrielle Aérospatiale v. United States Dist. Court for Southern Dist. Of Iowa, 482 U. S. 522, 524, 533 (1987) (international discovery rules); Sumitomo Shoji America, Inc. v. Avagliano, 457 U. S. 176, 181, 189-190 (1982) (employment practices); Trans World Airlines, Inc. v. Franklin Mint Corp., 466 U. S. 243, 245, 252 (1984) (air carrier liability); Kolovrat v. Oregon, 366 U. S. 187, 191, n. 6, 198 (1961) (property rights and inheritance); Clark v. Allen, 331 U. S. 503, 507-508, 517-518 (1947) (same); Bacardi Corp. of America v. Domenech, 311 U. S. 150, 160, and n. 9, 161 (1940) (trademark); Todok v. Union State Bank of Harvard, 281 U. S. 449, 453, 455 (1930) (property rights and inheritance); Nielsen v. Johnson, 279 U. S. 47, 50, 58 (1929) (taxation); Jordan v. Tashiro, 278 U. S. 123, 126-127, n. 1, 128-129 (1928) (trade and commerce). In: MEDELLIN v. TEXAS Certiorari to the Court of Criminal Appeals of Texas. No. 06-984. Argued October 10, 2007Decided March 25, 2008, p.82 e ss.
} 
suprema da terra" ${ }^{234}$ Um exemplo de caso envolvia o Tratado de Paris (1783), que o Congresso não promulgou uma lei federal interna para tornar executórias as suas provisões. Em seguida ele questiona a necessidade de um tratado constar explicitamente em seu teor que é auto-executável, o que não prova nada, porque a própria supremacy clause não explicita isso. ${ }^{235}$

BREYER, SOUTER e GINSBURG explicam porque votaram pela autoexecutoridade da Convenção de Viena sobre Relações Consulares de 1963, e porque as decisões da Corte Internacional de Justiça têm efeitos domésticos juridicamente vinculantes, pela própria redação dos tratados (Convenção de Viena, Protocolo Opcional, Carta das Nações Unidas e Estatuto da Corte Internacional de Justiça). Muito embora nenhum deles explicite que vincula o país-Membro em termos de Direito doméstico, porque isso depende da lei interna de cada país, e no caso dos Estados Unidos, a supremacy clause. BREYER indagou o que haveria de errado com a expressão "conformar-se", do artigo 94 da Carta das Nações Unidas, citando a definição contida no Webster's New International Dictionary 2770 (2d ed. 1939), assim como a versão do dispositivo em espanhol, " compromete a cumplir", concluindo que há sim uma obrigação de execução, e não de posterior ato político. Aliás, a consequencia dessa leitura é a de colocar o destino de uma promessa internacional feita pelos Estados Unidos à mercê da boa vontade dos Estados. E isso é exatamente o que a supremacy clause busca evitar. Todavia, o dispositivo em questão é muito confortável para o País, já que tem poder de veto no Conselho de Segurança. ${ }^{236}$

\footnotetext{
${ }^{234}$ Medellin v. Texas - Certiorari to the Court of Criminal Appeals of Texas. No. 06-984. Argued October 10, 2007-Decided March 25, 2008, p. 54.

${ }^{235}$ The present Constitution of the United States affords the first instance of any government which, by saying treaties should be the supreme law of the land made it indispensable that they should be published for the information of all. At the same time I admit that a treaty, when executed pursuant to full power, is valid and obligatory, in point of moral obligation, on all, as well on the legislative, executive, and judicial departments (so far as the authority of either extends, which in regard to the last, must in this respect be very limited) as on every individual of the nation, unconnected officially with either, because it is a promise in effect by the whole nation to another nation, and if not in fact complied with, unless there be valid reasons for noncompliance, the public faith is violated. Ware v. Hylton 3 U.S. 3 Dall. 199199 (1796). Disponível online em: <http://supreme.justia.com/us/3/199/case.html> (acesso em 19/06/2009).
}

${ }^{236}$ Medellin v. Texas - Certiorari to the Court of Criminal Appeals of Texas. No. 06-984. Argued October 10, 2007-Decided March 25, 2008, p. 67. 
Por essas e outras razões, os Jutices BREYER, SOUTER e GINSBURG, defenderam a auto-executoridade da decisão do caso AVENA, especificamente, no tribunal do Texas. Corre-se o risco de privar os indivíduos, incluindo as empresas, proprietários, beneficiários de testamentos, funcionários consulares, e outros, da viável a resolução de litígios por meio de procedimentos que muitos tratados, incluindo comerciais, prevêem. Em um mundo onde o comércio e as viagens se tornaram cada vez mais internacionais, pensar assim é um passo na direção errada, contrariando a Supremacy Clause. E o papel da Suprema Corte é o de escolher como se daria a revisão e reconsideração ordenada pela sentença AVENA, ou os tribunais do Texas, conforme intenção Memorando do Presidente Bush, que tem sim autoridade constitucional para manifestar-se sobre a implementação de tratado. ${ }^{237}$

O Juiz STEVENS, favorável à suspensão da execução do mexicano, por força da decisão da Corte Internacional de Justiça, manifestou-se da seguinte forma, no último pedido de habeas corpus apresentado por MEDELLín, writ of certionari, que apenas atrasou sua execução em pouco mais de 5 horas, em 05 de agosto de $2008:^{238}$

\begin{abstract}
"I wrote separately to make clear my view that Texas retained the authority - and, indeed, the duty as a matter of international law-to remedy the potentially significant breach of the United States' treaty obligations identified in the President's Memorandum to the Attorney General. Because it appears that Texas has not taken action to address the serious national security and foreign policy implications of this suit, I believe we should request the views of the Solicitor General, who argued on behalf of the Executive Branch in earlier proceedings in the suit, before allowing Texas to proceed with the execution.

(...) The costs of refusing to respect the ICJ's judgment are significant. The entire Court and the President agree that breach will jeopardize the United States' 'plainly compelling' interests in 'ensuring the reciprocal observance of the Vienna Convention, protecting relations with foreign governments, and demonstrating commitment to the role of international law. ${ }^{239}$
\end{abstract}

\footnotetext{
${ }^{237}$ Medellin v. Texas - Certiorari to the Court of Criminal Appeals of Texas. No. 06-984. Argued October 10, 2007-Decided March 25, 2008, pp. 75-77.

${ }^{238}$ The Supreme Court of the United States. Jose Ernesto Medellin v. Texas. On application to recall and stay mandate and for Stay and petition for a Writ of Certiorari to the Court of Criminal Appeals of Texas. On Application for Stay and on Petition for a Writ of Habeas Corpus. 05 de agosto de 2008.

${ }^{239}$ The Supreme Court of the United States. Jose Ernesto Medellin v. Texas. On application to recall and stay mandate and for Stay and petition for a Writ of Certiorari to the Court of Criminal Appeals
} 
Nesse mesmo julgamento da Suprema Corte, BREYER alegou que: ${ }^{240}$

\begin{abstract}
"The United States has agreed that the ICJ's judgments will have "binding force between the parties and in respect of [a] particular case." United Nations Charter, Art. 59, 59, Stat. 1062, T. S. No. 993 (1945). (...) the question before us is whether the United States will carry out its international legal obligation to enforce the decision of the ICJ. As it is, the request will be mooted by petitioner's execution, which execution, as I have said, will place this Nation in violation of international law. For the reasons set forth, I respectfully dissent."
\end{abstract}

No entanto, para a maioria dos julgadores da Suprema Corte americana foram irrelevantes o pedido do próprio Presidente em Memorando, tampouco o "apelo" da comunidade internacional, que apresentou amicus curiae, como a União Européia, a Anistia Internacional e o Secretário Geral das Nações Unidas, BAN KI-MOON. Para os Estados Unidos, a proteção conferida pela Convenção de Viena é um direito inter-Estatal, conforme interpretação de seu Preâmbulo, e tem como base a reciprocidade, nacionalidade, função, aplicada entre Estados partes, com relação aos nacionais destes - o direito à assistência consular para preso estrangeiro não seria um "direito humano". ${ }^{241}$

Em 05 de agosto de 2008, JosÉ ERNESTO MEDELLín foi executado no estado do Texas, por injeção letal, à margem do Direito Internacional. Sobre isso, RICK KIRGIS, e Secretário da American Society of International Law manifestou o seguinte: ${ }^{242}$

\footnotetext{
"If the state of Texas goes ahead with the planned execution of José Ernesto Medellin without allowing him any judicial reconsideration of his murder conviction and his death sentence (to determine whether he was prejudiced by the Texas authorities' failure to notify him of his right to contact the Mexican consulate after he was arrested), the United States
}

of Texas. Application for Stay and on Petition for a Writ of Habeas Corpus. 05 de agosto de 2008, pp. 01-02.

${ }^{240}$ The Supreme Court of the United States. Jose Ernesto Medellin v. Texas. On application to recall and stay mandate and for Stay and petition for a Writ of Certiorari to the Court of Criminal Appeals of Texas. Application for Stay and on Petition for a Writ of Habeas Corpus. 05 de agosto de 2008, pp. 9 e ss.

${ }^{241}$ Memorial apresentado pelos Estados Unidos, perante a Corte Internacional de Justiça, no caso Avena, p. 121 e ss.

${ }^{242}$ KIRGIS, Rick. Medellín execution violates ICJ decision in Avena. Jurist Legal News \& Research. Disponível online em: < http://jurist.law.pitt.edu/hotline/2008/05/medelln-execution-violates-icjdecision.php> (acesso em 05 de junho de 2009). 
will breach its obligation under the United Nations Charter and the Statute of the International Court of Justice (ICJ) to comply with the decision of the ICJ against the United States in the Avena case. In that case the ICJ held that the failure to provide review and reconsideration for Medellin and similarly-situated Mexican nationals convicted of murder in the United States was a violation of the Vienna Convention on Consular Relations (the Vienna Convention). Under the UN Charter and ICJ Statute, the ICJ decision is final and binding on the United States. The ICJ in the Avena case made the point that the U.S. obligation under the Vienna Convention exists irrespective of due process principles under U.S. constitutional law. Consequently, even if the execution of Medellin is permissible under the U.S. Constitution without any further judicial review, there still would be a violation not only of the international law consular-assistance rules in the Vienna Convention, but also of the rules in the UN Charter and ICJ Statute relating to compliance with ICJ judgments.

O Congresso norte-americano não se esforçou para acelerar a aprovação da legislação que torna perfeitamente claro que a Convenção de Viena sobre Relações Consulares de 1963 (ou pelo menos os artigos 36 e 37 relativos aos direitos de notificação consular) é auto-executável, para o fim de implementar a decisão Avena e aplicando seus termos aos outros mexicanos que permanecem no corredor da morte, revisando e reconsiderando suas condenações, por meios judiciais plausíveis. Por meio dessa lei, S. 1194: Consular Notification Compliance Act o Congresso pode criar uma causa de ação e especificar os demandantes, Estados ou seus nacionais detidos nos Estados Unidos. ${ }^{243} \mathrm{O}$ Congresso também poderia especificar uma solução adequada para qualquer violação.

Para EDWARD DUFFY as restrições constitucionais e políticas sobre o poder de celebrar tratados impedem o governo federal de exercer certos métodos para aplicar internamente a sentença AVENA. Existem três tipos de opção: aprovar legislação federal que criaria uma solução; buscando uma emenda constitucional, ou induzir os Estados a fornecer a revisão e reconsideração das sentenças e condenações em violação à Convenção de Viena. Para ele, a terceira opção é a mais praticável, a de induzir os estados a cumprirem voluntariamente com as decisões da Corte,

\footnotetext{
${ }^{243}$ A BILL to facilitate compliance with Article 36 of the Vienna Convention on Consular Relations, done at Vienna April 24, 1963, and for other purposes - acted pursuant to authority contained in articles I and VI of the Constitution of the United States. Disponível online em: < http://leahy.senate.gov/imo/media/doc/BillText-ConsularNotificationComplianceAct.pdf> (último acesso em 10/08/2011).
} 
preservando a autonomia das subdivisões políticas, pelos seus próprios meios e sem imposições a ponto de afetar sua autonomia. ${ }^{244}$

Um projeto de lei foi apresentado em 14 de julho de 2008 ao Congresso pelos membros da Câmara dos Deputados (House of Representatives), HOWARD BERMAN e ZOE LOFGREN, de número 6481, para a implementação do caso AVENA e criar uma ação civil para fornecer recursos judiciais com o fim de efetivar as obrigações dos Estados Unidos ao abrigo da Convenção de Viena sobre Relações Consulares, para quaisquer violações que tenham ocorrido antes, durante ou após a data da promulgação dessa lei. ${ }^{245}$

Enquanto isso, ao ignorarem suas obrigações internacionais, argüindo inúmeras objeções baseadas em seu direito doméstico, quanto à jurisdição da Corte Internacional de Justiça, agindo à margem da Carta das Nações Unidas e da sua própria Constituição, os Estados Unidos demonstram que permanecem presos "às amarras do positivismo jurídico" com aparente obsessão pelo já ultrapassado exercício da autonomia da vontade, ou consentimento, para cumprimento das

\footnotetext{
244 Duffy sugere que a lei Avena "Avena Act" fosse assim emitida pelo Congresso, para implementação da Convenção de Viena sobre Relações Consulares de 1963: "(a) No state or locality therein shall receive Justice Assistance Grant funding, unless that state satisfies the conditions set forth in parts $(b)$ and $(c)$ of this section. This section does not bind a state that refuses receipt of funds. (b) The state shall direct its agents to read the consular notification rights set forth in the Vienna Convention on Consular Notification, upon the arrest of an alien or realization that a person in state custody is an alien; the state shall then notify the nearest consulate of the alien's home country and allow a representative of that consulate to consult with the alien upon request. (c) In the event that an alien is detained for forty-eight hours or more before receiving the notification required by part (b) of this section, or if credible evidence is presented that state officials knew of the alien's status and deliberately delayed in informing him or her of his or her rights under the Vienna Convention, then the state must provide for a hearing to determine if prejudice occurred regardless of when the alien raises this claim and irrespective of state procedural default rules. (d) The AntiTerrorism and Effective Death Penalty Act shall not be construed as precluding the hearing required by part (c) of this section. (e) This section shall not be construed as preventing states or localities from providing additional remedies than those provided in this section." DUFFY, Edward. The Avena Act: An Option To Induce State Implementation of Consular Notification Rights After Medellín. $\quad<h t t p: / / l e g a l w o r k s h o p . o r g / 2010 / 09 / 13 /$ the-avena-act-an-option-to-induce-stateimplementation-of-consular-notification-rights-after-medellin>, acesso em: (21/03/2011).
}

245 Tracking the United States Congress. Disponível online em: <http://www.govtrack.us/congress/billtext.xpd?bill=h110-6481> (acesso em 21/03/2011). 
obirgaçoes internacionais. Conforme leciona o atual Juiz da Corte Internacional de Justiça, CANÇADO TRINDADE, sobre os "realistas e positivistas": ${ }^{246}$

\begin{abstract}
"Desvendaram uma visão estática do mundo, ignorando por completo sua dimensão temporal. Isolaram o Direito de outras áreas do conhecimento. Uns e outros revelaram uma auto-suficiência própria dos arrogantes. Definitivamente, ser positivista ou realista é demasiadamente fácil, porquanto não requer erudição alguma, tampouco maiores conhecimentos. (...) prestam um desserviço ao Direito Internacional, ignoram os princípios gerais do direito, além de desvendar as distorções, a letargia e a indigência mental de segmentos da "doutrina" jusinternacionalista contemporânea”.
\end{abstract}

Ainda nesse sentido: ${ }^{247}$ "O Direito Internacional não se reduz, em absoluto, a um instrumental a serviço do poder; seu destinatário final é o ser humano, devendo atender a suas necessidades, entre as quais, a realização da justiça.”

Em 1969, os Estados Unidos, seguindo o conselho e consentimento do Senado, ratificaram a Convenção de Viena sobre Relações Consulares de 1963 ([1970] 21 UST 77, T.I.A.S. . $^{\circ}$ 6820), e o Protocolo Facultativo relativo à resolução obrigatória de controvérsias ([1970] 21 UST 325, T.I.A.S. n.o 6820), que determina o foro para a resolução de litígios decorrentes da interpretação ou aplicação da Convenção "devem encontrar-se no âmbito da jurisdição obrigatória da Corte Internacional de Justiça" e "podem, portanto, ser submetidas à Corte (...) por qualquer das partes em litígio que seja Parte do presente Protocolo". ${ }^{248}$ Em havendo

\footnotetext{
${ }^{246}$ CANÇADo TRIndade, A. A. A Humanização do Direito Internacional. Belo Horizonte: Del Rey, 2006, p. 21. Cançado Trindade ensina que não há como dissociar a formação do Direito Internacional dos aspectos atinentes a seus próprios fundamentos. (...) o "restauração do direito natural; a degeneração do positivismo jurídico, a força moral da consciência humana, a opinio iurus, os princípios do direito, o "direito de consciência"; o despertar da "consciência jurídica da comunidade internacional", que reflete valores que estão acima da vontade dos Estados. E que a Corte, no caso Barcelona Traction (Bélgica v. Espanha, de 1970), considerou elementos desenvolvidos a partir da noção básica de humanidade. In: Tratado de Direito Internacional dos Direitos Humanos, p. 84 e SS.

El desarraigo como problema humanitario y de derechos humanos frente a la conciencia jurídica universal. Lecciones y Ensayos. Buenos Aires. n.78. p.71-116. 2003.

${ }^{248}$ SARAH M. RAY conta que em 1969, o Senado norte-americano ratificou a Convenção. O atraso de seis anos entre a assinatura e a ratificação foi em grande parte devido a uma preocupação que, como um tratado multilateral sob reserva de aprovação por muitas nações, a Convenção de Viena de 1963 representou uma versão diluída de protecção dos cidadãos estrangeiros em relação aos tratados
} 
ratificado o Protocolo Facultativo à Convenção de Viena sobre Relações Consulares de 1963, consentiram submeterem-se à jurisdição compulsória da Corte para solução de controvérsias relacionadas à Convenção de Viena de 1963.

No entanto, as conseqüências do caso AVENA parecem ter sido mesmo relevantes, tanto que um ano após o julgamento de 31 de março de 2004, os Estados Unidos denunciaram por meio de Carta enviada ao Secretário Geral das Nações Unidas, a aceitação da jurisdição específica da Corte Internacional de Justiça, pela qual se sujeitaram por meio da ratificação do Protocolo Facultativo à Convenção de Viena sobre Relações Consulares de 1963 sobre Solução Compulsória de Controvérsias $^{249}$. Em 07 de março de 2005, posterior à decisão AvENA, os Estados Unidos deram o aviso de denúncia do Protocolo, por meio de carta de ConDOLEEZZA Rice, Secretária de Estado, a Kofi A. Annan, Secretário-Geral das Nações Unidas. Já haviam denunciado à jurisdição geral da Corte, quando do desgosto pelo caso Nicarágua, em $1985 .^{250}$

bilaterais de que os Estados Unidos eram parte. Após a ratificação, a referida Convenção, assim, tomou seu lugar como "Lei Suprema da Terra", nos moldes da Constituição americana, a par com a legislação federal e superior à lei estadual e de políticas. Portanto, os termos da referida Convenção se aplicam à conduta do Estado e à aplicação da lei federal, deve ser executadas nos tribunais estaduais e federais, e prevalecem sobre quaisquer leis estaduais conflitantes. A Convenção de Viena de 1963 é auto-executável, foi devidamente ratificada pelo Senado norte-americano (115 Cong. Rec. S30, 953, S30,997 (daily ed. Oct. 22, 1969), incorporando-se ao direito nacional e, portanto, não requer qualquer legislação posterior implementatória que permita aos tribunais e aos indiviíduos em questão fazerem valer os direitos que ela cria. O problema com a execução judicial interna da Convenção tem sido e continua a ser a confusão sobre quais são direitos realmente criados pela referida Convenção. Até este ponto, a Suprema Corte se recusou a responder a essa pergunta com clareza. No entanto, só precisa olhar para seus próprios precedentes para determinar que as decisões da Corte podem ser implementadas internamente. Ray,Sarah M., Domesticating International Obligations: How to Ensure U.S. Compliance with the Vienna Convention on Consular Relations, pp. 1734-1735.

249 "(...) Expressing their wish to resort in all matters concerning them in respect of any dispute arising out of the interpretation or application of the Convention to the compulsory jurisdiction of the International Court of Justice, unless some other form of settlement has been agreed upon by the parties within a reasonable period, Have agreed as follows : Article I. Disputes arising out of the interpretation or application of the Convention shall lie within the compulsory jurisdiction of the International Court of Justice and may accordingly be brought before the Court by an application made by any party to the dispute being a Party to the present Protocol." Optional Protocol concerning the Compulsory Settlement of Disputes. United Nations Conference on Consular Relations Vienna, Austria, 4 March - 22 April 1963. Document: A/CONF.25/15.

${ }^{250}$ Secretary's Letter to UN Secretary General, OCT. 7, 1985 Dear Mr. Secretary-General: I have the honor on behalf of the Government of the United States of America to refer to the declaration of my Government of 26 August 1946, as modified by my note of 6 April 1984, concerning the acceptance by the United States of America of the compulsory jurisdiction of the International Court of Justice, and to state that the aforesaid declaration is hereby terminated, with effect six months from the date hereof. Sincerely Yours, George P. Shultz. Department Statement, OCT. 7, 1985. (...) Disponível 
Talvez seja um receio de se sujeitar a qualquer jurisdição internacional obrigatória, mas que resulta na violação de obrigações internacionais, e conseqüente responsabilização internacional. Além do mais, custam enxergar que poderão deixar seus próprios cidadãos, em qualquer Estado Receptor afora, a mercê e sem a proteção consular garantida pela Convenção de Viena sobre Relações Consulares de 1963. PAULO BORBA CASELlA ${ }^{251}$ analisa a gravidade disso sob dois ângulos distintos: de um lado, a opinião interna do País pode ter confundido a atuação da Corte como principal tribunal internacional para solução de controvérsias entre Estados, com aplicação e interpretação do Direito Internacional. Isso devido à idéia equivocada de enxergá-la como uma instância adicional à interna, de apelação criminal, em relação a estrangeiros que viessem a ser julgados e condenados por tribunais americanos após o esgotamento dos recursos internos.

Ora, trata-se, acima de tudo, de responsabilidade internacional do Estado por violação de obrigação internacional, depois de assinar e ratificar tratado, por não fazê-lo cumprir, não somente em âmbito internacional, mas também internamente, por seus tribunais e sua administração nacional e subdivisões administrativas. Somente o Estado, enquanto sujeito de Direito Internacional, pode assegurar o cumprimento interno de suas obrigações internacionais. Por outro lado, PAUlo CASElla ${ }^{252}$ ressalta que a Corte Internacional de Justiça cumpriu com sua função primordial de decidir conforme o Direito Internacional. Assim, a reação dos Estados Unidos é um péssimo precedente no cenário internacional, e um verdadeiro "retrocesso no esforço de implementação e aplicação consistentes do Direito Internacional".

Independentemente da reação dos Estados Unidos quanto à implementação das decisões da Corte Internacional de Justiça, e conseqüente denúncia da aceitação da sua jurisdição compulsória, o principal órgão judicial das

online em: <http://findarticles.com/p/articles/mi_m1079/is_v86/ai_4076208/> (acesso em 20/06/2009).

${ }^{251}$ CASELlA, Paulo Borba. Fundamentos do Direito Internacional Pós-Moderno, pp. 1261-2.

${ }^{252}$ CASELlA, Paulo Borba. Fundamentos do Direito Internacional Pós-Moderno, pp. 1262. 
Nações Unidas sem dúvidas demonstrou maturidade e discernimento na sua fundamentação.

Além de esclarecer e avançar e esclarecer para todos os Estados partes do tratado, o entendimento sobre o direito de informação sobre assistência consular para preso estrangeiro, considerando-o como sendo um direito individual, a Corte Internacional de Justiça mostrou o fortalecimento das suas bases perante as usuais objeções com relação à sua jurisdição e competência. Em sendo o principal tribunal internacional, teve um relevante papel a cumprir, enquanto instituição e enquanto responsável pela "efetividade da aplicação e controle da consistência de interpretação do Direito Internacional, ao menos entre Estados, e ao menos às questões que à Corte sejam submetidas." ${ }^{253}$ Interpretações e esclarecimentos que devem orientar todos os Estados partes da Convenção de Viena sobre Relações Consulares de 1963, inclusive o Brasil, na efetivação interna dos direitos previstos pelo artigo 36 do tratado, no que se refere ao preso estrangeiro.

${ }^{253}$ CASELlA, Paulo Borba. Fundamentos do Direito Internacional Pós-Moderno, pp. 1262. 


\section{Capítulo 7}

\section{Corte Interamericana de Direitos Humanos - Opinião Consultiva Número 16, de $1^{\circ}$ De OUTUbro de 1999, solicitada PELO MÉXico, RELACIONADA AO DIREITO DE INFORMAÇÃo SOBRE A ASSISTÊNCIA CONSULAR NO ÂMBITO DAS GARANTIAS DO DEVIDO PROCESSO LEGAL}

A proposta da presente dissertação não envolve uma análise aprofundada do impacto das Opiniões Consultivas (também chamadas Pareceres Consultivos) no Direito brasileiro. No entanto, é inerente a ela o estudo da Opinião Consultiva n. ${ }^{0} 16$ de 01 de outubro 1999, emitida pela Corte Interamericana de Direitos Humanos, referente ao direito de informação sobre a assistência consular no âmbito das garantias do devido processo legal.

Apesar de o Governo brasileiro ter aderido Convenção Americana de Direitos Humanos por ato internacional em 25 de setembro de 1992 (Pacto de São José da Costa Rica), promulgado-a por força do Decreto n. ${ }^{\circ}$ 678, de 06 de novembro de 1992, o Brasil optou pela não vinculação à cláusula facultativa de reconhecimento da jurisdição compulsória ${ }^{254}$ da Corte Interamericana de Direitos Humanos naquela ocasião. Dez anos depois o Brasil autorizou o reconhecimento da jurisdição, que se deu por ato internacional do Brasil em 10 de dezembro de 1998pelo Decreto Legislativo n. ${ }^{\circ} 89$ de 3 de dezembro de 1998, o qual dispõe que somente poderão ser submetidas à Corte Interamericana as denúncias de violações ocorridas a partir do

\footnotetext{
${ }^{254}$ Convenção Americana de Direitos Humanos, artigo 62: "1. Todo Estado-Parte pode, no momento do depósito do seu instrumento de ratificação desta Convenção ou de adesão a ela, ou em qualquer momento posterior, declarar que reconhece como obrigatória, de pleno direito e sem convenção especial, a competência da Corte em todos os casos relativos à interpretação ou aplicação desta Convenção."
} 
reconhecimento da jurisdição. ${ }^{255}$ Mas, com relação às Opiniões Consultivas, o Brasil passo a reconhecê-las juridicamente desde que aderiu a Convenção Americana, em 25 de setembro de $1992 .^{256}$

Decreto $\mathrm{n}^{\circ} 4.463$, de 8 de novembro de 2002 promulga a Declaração de Reconhecimento da Competência Obrigatória da Corte Interamericana de Direitos Humanos, sob reserva de reciprocidade, em consonância com o art. 62 da Convenção Americana sobre Direitos Humanos (Pacto de São José), de 22 de novembro de 1969

Diferente da competência contenciosa, mas não menos fundamental, a competência consultiva da Corte Interamericana de Direitos Humanos está prevista no artigo 64.1 da Convenção Americana sobre Direitos Humanos, e cuida da interpretação dessa Convenção ou de outros tratados concernentes à proteção dos direitos humanos nos Estados americanos. ${ }^{257}$ As Opiniões Consultivas auxiliam na interpretação judicial e fixação do conteúdo e alcance do Direito Internacional contemporâneo, porque declaram o Direito Internacional e, desta maneira, possibilitam melhor certeza jurídica aos sujeitos de Direito Internacional. ${ }^{258}$

\footnotetext{
${ }^{255}$ ARAÚJO, Nadia de. A influência das opiniões consultivas da Corte Interamericana de Direitos Humanos no ordenamento jurídico brasileiro... p. 229.

${ }^{256}$ BRAWERMAN, André e outros. Jurisprudência da Corte Interamericana de Direitos Humanos. 2.1 Jurisdição Consultiva. 2.1.1 Nota Introdutória à Jurisdição Consultiva da Corte Interamericana de Direitos Humanos. Disponível online em: $<$ http://www.pge.sp.gov.br/centrodeestudos/bibliotecavirtual/interamericano/211nota.htm> (acesso em 24/06/2009).

257 Regulamento da Corte Interamericana de Direitos Humanos: Artigo 60. Interpretação da Convenção. "1. As solicitações de parecer consultivo previstas no artigo 64.1 da Convenção deverão formular com precisão as perguntas específicas em relação às quais pretende-se obter o parecer da Corte. 2. As solicitações de parecer consultivo apresentadas por um Estado membro ou pela Comissão deverão indicar, adicionalmente, as disposições cuja interpretação é solicitada, as considerações que dão origem à consulta e o nome e endereço do Agente ou dos Delegados. 3. Se o pedido de parecer consultivo é de outro órgão da OEA diferente da Comissão, a solicitude deverá precisar, além do indicado no parágrafo anterior, como a consulta se refere à sua esfera de competência". Artigo 61. Interpretação de outros tratados. "1. Se a solicitação referir-se à interpretação de outros tratados concernentes à proteção dos direitos humanos nos Estados americanos, tal como previsto no artigo 64.1 da Convenção, deverá identificar o tratado e suas respectivas partes, formular as perguntas específicas em relação às quais é solicitada o parecer da Corte e incluir as consideraçães que dão origem à consulta. 2. Se a solicitação emanar de um dos órgãos da Organização dos Estados Americanos, deverá explicar como a consulta se refere à sua esfera de competência."

${ }^{258}$ RAMOS, André de Carvalho. Direitos Humanos em Juízo, pp. 341-2. Ele ressalta que, na falta do reconhecimento da jurisdição obrigatória das Cortes Internacionais pelos Estados, para solução de seus litígios, resta a competência consultiva. A ausência de força vinculante de suas Opiniões Consultivas já foi reconhecida pela Corte, desde 24 de setembro de 1982, em sua Opinião Consultiva n. ${ }^{0} 1$.
} 
No âmbito consultivo, o é efeito multilateral e não-vinculante porque produzem-se efeitos jurídicos além do Estado solicitante, mas não obriga como em como uma sentença em caso contencioso. Não existe um litígio formal a resolver, portanto, não se analisam provas, não há contraditório e tampouco partes litigantes. Daí, não se pode supor a força juridicamente vinculante desses pareceres. A Corte apenas interpreta a norma internacional aplicável, faz o reconhecimento de hipóteses fáticas orienta e decide se esses podem ser considerados como violadores de algum tratado. ${ }^{259}$. Daí, exerce a importante função de orientar o caminhar de cada Estado, no sentido de não desobedecer todo o ordenamento jurídico, nacional ou internacional, que proteja os direitos fundamentais do ser humano. Firma o que é o Direito na esfera interamericana de proteção dos direitos humanos. Tem por finalidade a de esclarecer dúvidas quanto à interpretação de determinada norma de direito interno ou conduta de um Estado em relação às obrigações assumidas nos termos da Convenção Americana de Direitos Humanos. ${ }^{260}$ É assim que auxilia na prevenção, ou até mesmo evita conflitos entre a jurisdição internacional e nacional, e na harmonização da legislação nacional com as obrigações convencionais. ${ }^{261}$

${ }^{259}$ Opinião Consultiva Número 16 de $1^{\circ}$ de outubro de 1999, solicitada pelos Estados Unidos Mexicanos perante à Corte Interamericana de Direitos Humanos. O direito de informação sobre a assistência consular no âmbito das garantias do Devido Processo Legal, parágrafos 47-8.

${ }^{260}$ São duas as espécies de Opiniões Consultivas: interpretativas de tratados internacionais de direitos humanos do sistema americano, e os pareceres sobre a compatibilidade entre leis e projetos de leis internos (conforme a decisão da Corte no Parecer n. ${ }^{\circ}$ 12/91) e a Convenção Americana de Direitos Humanos. As Opiniões de caráter interpretativo de normas americanas de direitos humanos "compõem o controle de interpretação" dessas normas e demonstram a orientação da Corte, "em abstrato da Corte para os operadores internos do Direito". Por sua vez, as Opiniões Consultivas que se referem à compatibilidade do Direito interno dos Estados com a Convenção formam o "controle de convencionalidade em abstrato" previsto pela Convenção Americana de Direitos Humanos. Ambos os controles, de interpretação e de convencionalidade, prescindem de litígio ou de pretensas vítimas, ainda que não sejam considerados juridicamente vinculantes. RAMOS, André de Carvalho. Direitos humanos em juízo, pp. 345-346.

${ }^{261}$ Não podemos deixar de comentar a possibilidade de utilização da competência consultiva para apreciação de situações jurídicas pré-existentes, e que poderiam resultar em futuros procedimentos contenciosos. Aqui, o Estado estaria solicitando uma opinião jurídica abstrata, indireta de jurisdição contenciosa, sem o consentimento do Estado interessado, como que para basear o futuro processo contencioso. Para o Professor ANDRÉ DE CARVAlHo RAMOs, nesses casos, "a Corte estaria sendo solicitada e seria aplicada em face de normas jurídicas essenciais para a resolução de casos concretos ainda não submetidos à jurisdição contenciosa da Corte. Isso seria uma "sobreposição de competências". Mesmo assim, a Corte tem emitido seus pareceres. O que não pode haver é o uso do mecanismo consultivo quando houver possibilidade de prejuízo para pretensas vítimas de violações de direitos humanos, caso o propósito deliberado de alterar o trâmite de caso já pendente perante outro órgão, como a Comissão Americana de Direitos Humanos, e desvirtuar todo o sistema americano de proteção dos direitos humanos. O Estado interessado não pode fiar-se na ausência de força vinculante das Opiniões Consultivas da Corte para não cumprir com suas ponderações. RAMOS, André de Carvalho. Direitos humanos em juízo, pp. 342-5. Na Opinião Consultiva n. ${ }^{\circ} 3$ da Corte Interamericana de Direitos Humanos CORTE INTERAMERICANA DE DIREITOS HUMANOS. Restrições à 
Desta forma a Corte tem emitido, sucessivamente, elementos preciosos para a caracterização do conteúdo, sentido propósito e alcance de diversos dispositivos da Convenção Americana sobre Direitos Humanos, aquilo que o ANDRÉ DE CARVALHO RAMOS refere ser a "coisa interpretada", sem ter a força vinculante da "coisa julgada", mas imprescindível na sociedade internacional, em que os sujeitos atuam como produtores e aplicadores do Direito Internacional. ${ }^{262}$

NADIA DE ARAúJO ressalta que mesmo os Estados que ainda não reconheceram a jurisdição obrigatória da Corte, podem sim aproveitar as decisões em opiniões consultivas para esclarecer o conteúdo e o alcance do Direito Internacional atual. Embora não sejam vinculantes, ao interpretarem e declararem o Direito Internacional, garantem maior certeza jurídica, evitando-se, assim, futuras violações de direitos humanos, independentemente de ter ou não o Estado reconhecido a jurisdição compulsória da Corte. É desta forma que as Opiniões Consultivas auxiliam na consagração da posição da Corte sobre os direitos humanos no continente americano, impedindo interpretações unilaterais dos Estados que, não raro, buscam esvaziar o sentido da norma de proteção. ${ }^{263}$

Pena de Morte (Artigos. 4.2 e 4.4 da Convenção Americana sobre Direitos Humanos. Opinião Consultiva OC-3/83 de 8 de setembro de 1983. Serie A, N. ${ }^{\circ} 3$, parágrafo 24. "A Corte reconhece, desde logo, que o interesse do Estado pode ser afetado de uma maneira ou de outra, por uma interpretação dada em uma Opinião Consultiva (...)" que "pode debilitar ou fortalecer a posição legal de um Estado em uma controvérsia atual ou futura". A solução é respeitar o Regulamento em todo procedimento (artigo 52). A Corte recusou a prolação de Opinião Consultiva solicitada pela Costa Rica, alegando que as questões solicitadas estavam sendo processados pela Comissão, o que poderia arriscar a privação de participação das pretensas vítimas , vez que

${ }^{262}$ RAMOS, André de Carvalho. Direitos humanos em juízo, p. 347.

263 ARAÚJO, Nadia de. A influência das opiniões consultivas da Corte Interamericana de Direitos Humanos no ordenamento jurídico brasileiro..., pp. 231 e 232. Ela ressalta que os pareceres consultivos podem ser de dois tipos: 1) de controle da interpretação das normas americanas de direitos humanos, nos quais se fixa a orientação da Corte para os operadores internos do Direito, e; 2) de controle de leis ou projetos com relação às disposições da Convenção Americana, em que se analisa sobre a incompatibilidade entre os primeiros e a Convenção. Id., p. 232. Desde 1982, na sua primeira Opinião Consultiva, a própria Corte esclareceu que, antes de tudo e principalmente, é uma instituição judicial autônoma que tem competência para decidir qualquer caso contencioso relativo à interpretação e aplicação da Convenção Americana de Direitos Humanos. Que sua função consultiva não pode desvincular-se dos propósitos do Pacto de San José, cuja finalidade é coadjuvar ao cumprimento das obrigações internacionais dos Estados Americanos no que concerne proteção dos direitos humanos, assim como ao cumprimento das funções atribuídas aos distintos órgãos da Organização dos Estados Americanos. Que a Corte Interamericana interpreta tal como tem feito a Corte Internacional de Justiça, cuja competência consultiva é de natureza permissiva, apreciando as possíveis circunstâncias em se baseia a consulta são tais que a levam a não dar resposta alguma, caso perceber que isso ultrapassaria sua função interpretativa (Cf. Interpretation of Peace Treaties, 1950 I.C.J. 65). Opinião Consultiva . $^{\circ} 1 / 82$, referente "a outros tratados" objeto da função consultiva da Corte (artigo 64 da Convenção Americana sobre Direitos Humanos), solicitada pelo Peru, Parágrafos 
Têm legitimidade para consultar a Corte os Estados-membros da Convenção Americana e os demais órgãos da Organização dos Estados Americanos, assim como a Comissão Interamericana de Direitos Humanos. Como instituição judicial autônoma que é, a Corte não se subordina a casos contenciosos julgados por outras instâncias internacionais como, por exemplo, a Corte Internacional de Justiça, sendo inclusive possível a contradição entre ambas. ${ }^{264}$

\subsection{A Opinião Consultiva Número 16, de $1^{\circ}$ de outubro de 1999 da Corte Interamericana de Direitos Humanos}

Em 09 de dezembro de 1997, o governo do México, no marco do artigo 64.1 da Convenção Americana de Direitos Humanos ${ }^{265}$, submeteu à Corte Interamericana de Direitos Humanos uma solicitação de Opinião Consultiva com

22-28. A Corte decidiu que pode exercer a sua competência consultiva, em geral, sobre toda disposição concernente à proteção dos direitos humanos, de qualquer tratado internacional aplicável nos Estados americanos, independentemente de ser bilateral ou multilateral, de qual seja seu objeto principal, ou de quem sejam ou possam ser partes do mesmo.

${ }^{264}$ Estatuto da Corte Interamericana de Direitos Humanos. (Aprovado pela resolução AG/RES. 448 (IX-O/79), adotada pela Assembléia Geral da Organização dos Estados Americanos, em seu Nono Período Ordinário de Sessões, realizado em La Paz, Bolívia, outubro de 1979). "Artigo $1^{o}$. Natureza e regime jurídico. A Corte Interamericana de Direitos humanos é uma instituição judiciária autônoma cujo objetivo é a aplicação e a interpretação da Convenção Americana sobre Direitos Humanos. A Corte exerce suas funções em conformidade com as disposições da citada Convenção e deste Estatuto." Isso porque, os Estados Unidos manifestaram que, por haver casos de matéria semelhante perante a Corte Internacional de Justiça (o caso BREARD, em que o Paraguai já havia retirado da lista de contenciosos em 10/11/1999, e outro pendente à época, o caso dos irmãos LAGRAND), ao emitir sua Opinião a Corte Interamericana poderia gerar confusão, prejudicar as posições legais das Partes e criar o risco de produzir "una disparidad entre los conceptos de la Corte Interamericana y los del principal órgano judicial de la $O N U$ ", sobretudo quando são partes da Convenção de Viena Estados além do continente americano, o que poderia causar problemas em outras regiões do mundo. E por ser a Convenção de Viena sobre Relações Consulares de caráter universal, um "tratado internacional interestatal tradicional", isto é, regula relações entre Estados, e jamais entre Estados e indivíduos, e muito menos dita direitos humanos, "la consulta constituye un claro intento de someter a los Estados Unidos de América a la competencia contenciosa de este Tribunal, aun cuando dicho Estado no es parte en la Convención Americana ni ha aceptado La competencia obligatoria de la Corte". O país chamou o caso de "caso contencioso encoberto". Opinião Consultiva Número 16, de $1^{\circ}$ de outubro de 1999, solicitada pelo México perante à Corte Interamericana de Direitos Humanos. O direito de informação sobre a assistência consular no âmbito das garantias do Devido Processo Legal, p. 17 e 32 .

265 “Artigo 64. 1. Os estados-membros da Organização poderão consultar a Corte sobre a interpretação desta Convenção ou de outros tratados concernentes à proteção dos direitos humanos nos estados americanos. Também poderão consultá-la, no que lhes compete, os órgãos enumerados no capítulo X da Carta da Organização dos Estados Americanos, reformada pelo Protocolo de Buenos Aires". 
doze perguntas quanto à interpretação de "diversos tratados concernentes à proteção dos direitos humanos nos Estados americanos", além da Convenção Americana de Direitos Humanos. A consulta tinha a ver precisamente com as garantias judiciais mínimas e o devido processo no âmbito da pena de morte imposta judicialmente a estrangeiros, sem que o Estado Receptor tivesse informado esses indivíduos sobre o direito de informação sobre a assistência consular.

Basicamente, a Corte Interamericana, por meio de uma interpretação evolutiva dos tratados internacionais de direitos humanos, considerou na Opinião Consultiva em estudo que o artigo 36 da Convenção de Viena sobre Relações Consulares de 1963 contém disposições concernentes à proteção de direitos humanos nos Estados americanos, ao reconhecer direitos individuais ao estrangeiro privado de liberdade no território do Estado Receptor. Para a Corte, o direito de informação sobre assistência consular corresponde à obrigação do Estado Receptor de garantir ao estrangeiro o pleno devido processo legal, ou seja, um julgamento imparcial, justo e equitativo, à luz da interpretação dos artigos 2, 6, 14 e 50 do Pacto Internacional de Direitos Civis e Políticos e da Declaração Americana e da Carta da Organização dos Estados Americanos. ${ }^{266}$.

\footnotetext{
${ }^{266}$ O Brasil promulgou o Pacto Internacional sobre Direitos Civis e Políticos por força do Decreto n.o $\mathrm{n}^{\circ}$ 592, de 6 de julho de 1992. Sobre o devido processo legal, artigo 14 do Pacto dispõe o seguinte: " 1 . Todas as pessoas são iguais perante os tribunais e as cortes de justiça. Toda pessoa terá o direito de ser ouvida publicamente e com as devidas garantias por um tribunal competente, independente $e$ imparcial, estabelecido por lei, na apuração de qualquer acusação de caráter penal formulada contra ela ou na determinação de seus direitos e obrigações de caráter civil. A imprensa e o público poderão ser excluídos de parte ou da totalidade de um julgamento, que por motivo de moral pública, de ordem pública ou de segurança nacional em uma sociedade democrática, quer quando o interesse da vida privada das partes o exija, quer na medida em que isso seja estritamente necessário na opinião da justiça, em circunstâncias específicas, nas quais a publicidade venha a prejudicar os interesses da justiça; entretanto, qualquer sentença proferida em matéria penal ou civil deverá tornar-se pública, a menos que o interesse de menores exija procedimento oposto, ou o processo diga respeito a controvérsia matrimoniais ou á tutela de menores. 2. Toda pessoa acusada de um delito terá direito a que se presuma sua inocência enquanto não for legalmente comprovada sua culpa. 3. Toda pessoa acusada de um delito terá direito, em plena igualdade, a, pelo menos, as seguintes garantias: a) de ser informado, sem demora, numa língua que compreenda e de forma minuciosa, da natureza e dos motivos da acusação contra ela formulada; $b$ ) de dispor do tempo e do meios necessários à preparação de sua defesa e a comunicar-se com defensor de sua escolha; c) de ser julgado sem dilações indevidas; d) de estar presente no julgamento e de defender-se pessoalmente ou por intermédio de defender de sua escolha; de ser informado, caso não tenha defensor, do direito que the assiste de tê-lo e, sempre que o interesse da justiça assim exija, de ter um defensor designado "ex offício" gratuitamente, se não tiver meios para remunerá-lo; e) de interrogar ou fazer interrogar as testemunhas da acusação e de obter o comparecimento e o interrogatório das testemunhas de defesa nas mesmas condições de que dispõe as de acusação; $f$ ) de ser assistida gratuitamente por um intérprete, caso não compreenda ou não fale a língua empregada durante o julgamento; g) de não ser obrigada a depor contra si mesma, nem a confessar-se culpada. 4. O processo aplicável a jovens
} 
O México alegou que assistência consular exercida oportunamente poderia ser determinante no resultado do processo penal, porque garante, entre outros efeito, que o preso estrangeiro adquira informações sobre seus direitos constitucionais e jurídicos naquela jurisdição a qual se encontra submetido, em seu próprio idioma e de forma acessível e igualitária. O funcionário consular pode assegurar que indivíduo nessa situação receba a assistência jurídica adequada e conheça as conseqüências legais do delito que lhe imputam. É assim que os funcionários consulares coadjuvar na preparação, coordenação e supervisão da defesa, e desenvolvendo um papel determinante na obtenção de provas atenuantes no Estado que envia. Assim, contribuem para tornar mais humanas as condições do acusado e seus familiares, de maneira a equilibrar a situação de real desvantagem e vulnerabilidade deles. ${ }^{267}$

Para a Corte Interamericana, o devido processo legal é preservado se o acusado sujeito a um procedimento penal tiver condições de exercer seus direitos e defender seus interesses de forma efetiva, em total igualdade procedimental, com relação a outros acusados nacionais do Estado Receptor, assegurando-se, na maior medida do possível, a solução justa e equitativa. Nessas circunstâncias, a informação sobre o direito de comunicar-se com o funcionário consular contribui para melhorar consideravelmente suas possibilidades de defesa, que se realiza com maior apego à

que não sejam maiores nos termos da legislação penal levará em conta a idade dos menores e a importância de promover sua reintegração social. 5. Toda pessoa declarada culpada por um delito terá o direito de recorrer da sentença condenatória e da pena a uma instância, em conformidade com a lei. 6. Se uma sentença condenatória passada em julgado for posteriormente anulada ou se indulto for concedido, pela ocorrência ou descoberta de fatos novos que provem cabalmente a existência de erro judicial, a pessoa que sofreu a pena decorrente dessa condenação deverá ser indenizada, de acordo com a lei, a menos que fique provado que se lhe pode imputar, total ou parcialmente, nãorevelação dos fatos desconhecidos em tempo útil. 7. Ninguém poderá ser processado ou punido por um delito pelo qual já foi absolvido ou condenado por sentença passada em julgado, em conformidade com a lei e os procedimentos penais de cada país."

267 Juristas, Organizações Não-Governamentais e indivíduos participaram na qualidade de Amicus Curie, havendo apresentado suas observações escritas em 27 de abril e 22 de maio de 1998, visando participarem da audiência pública que fora marcada pelo Presidente da Corte, para o dia 12 de junho de 1998, às 10:00 horas, cuja versão final foi transmitida para todos os presentes. Representantes do México, Costa Rica, El Salvador, Guatemala, Honduras, Paraguai, República Dominicana, Estados Unidos da América. Ainda, representantes da Comissão Interamericana de Direitos Humanos e; Anistia Internacional; Comissão Mexicana para a Defensa e Promoção dos Direitos Humanos; Human Rights Watch/Américas e o Centro para a Justiça e o Direito Internacional; Death Penalty Focus, California; Delgado Law Firm e o senhor Jimmy V. Delgado; International Human Rights Law Institute, DePaul University College of Law e MacArthur Justice Center, University of Chicago Law School; Minnesota Advocates for Human Rights e a senhora Sandra L. Babcock; Bonnie Lee Goldstein e William H. Wright, Jr.; Mark Kadish; José Trinidad Loza; John Quigley y S. Adele Shank; Robert L. Steele; Jean Terranova, e Héctor Gros Espiell. 
lei e dignidade das pessoas. A inobservância desse direito, por parte das autoridades competentes do Estado Receptor, afeta as garantias judiciais do devido processo legal, e no caso da pena de morte, o resultado é a privação arbitrária do direito de viver, com todas as conseqüências de responsabilização internacional e dever de reparação que isso resulta, pela violação do artigo $4^{\circ}$ da Convenção Americana de Direitos Humanos, bem como do artigo 6 do Pacto Internacional de Direitos Civis e Políticos, sem falar que fere o princípio da igualdade, estabelecido pela carta da Organização dos Estados Americanos. ${ }^{268}$

Por outro lado, os Estados Unidos, por ser Estado membro da Organização dos Estados Americanos, em resposta escrita de 1 de junho de 1998, havendo comparecido em audiência públicade 12 de junho de 1998, observações escritas em 18 de maio de 1999, argumentaram que a Corte não teria competência para emitir sua opinião sobre o pedido do México, porque o sequer haviam ratificado o Pacto de São José da Costa Rica, e não poderia a Corte reconhecer padrões mínimos de processo penal pertinente ao direito interno dos Estados, muito menos direito humano que não estaria previsto em qualquer dos principais tratados internacionais sobre Direitos Humanos.

Os Estados Unidos alegaram ainda que a Convenção de Viena de1963 não seria um tratado internacional de direitos humanos, mas tão somente um "tratado multilateral tradicional - inter-Estatal”, concluído em função de um intercâmbio recíproco de direitos para o beneficio mútuo dos Estados contratantes, e não entre Estados e indivíduos, conforme estabelece o próprio Preâmbulo da Convenção, “de que a finalidade de tais privilégios e imunidades não é beneficiar indivíduos, mas assegurar o eficaz desempenho das funções das repartições consulares, em nome de seus respectivos Estados". E que não existiria qualquer tratado internacional de direitos humanos, que apoiasse a pretensão do México, e que a inobservância do artigo 36 da Convenção não invalida o procedimento criminal doméstico a que o preso estrangeiro esteja submetido, porque não viola per se as garantias do devido processo legal e garantias judiciais. Portanto, a Corte Interamericana de Direitos

\footnotetext{
${ }^{268}$ Opinião Consultiva Número 16, de $1^{\circ}$ de outubro de 1999, solicitada pelo México perante à Corte Interamericana de Direitos Humanos. O direito de informação sobre a assistência consular no âmbito das garantias do Devido Processo Legal, parágrafos 117-129 e 137.
} 
Humanos nem seria competente, até porque os Estados Unidos não são parte da Convenção Americana de Direitos Humanos e, muito menos, aceitaram a jurisdição contenciosa da Corte Interamericana de Direitos Humanos. ${ }^{269}$

A Corte Interamericana de Direitos Humanos repudiou os argumentos apresentados pelos Estados Unidos, ressaltando que se limitasse sua competência consultiva a Estados membros da Organização dos Estados Americanos e que fossem parte da Convenção Americana sobre Direitos Humanos ficaria com seu alcance muito reduzido. Também asseverou que não se sujeita aos casos da Corte Internacional de Justiça porque é uma instituição judicial autônoma, isto é, não existe uma hierarquia. Para declarar sua competência, considerou que tanto o México quanto os Estados Unidos são membros da Organização dos Estados Americanos, celebraram a Declaração Americana, ratificaram o Pacto Internacional de Direitos Civis e Políticos e são partes da Convenção de Viena sobre Relações Consulares, independentemente de haverem ambos ratificado, ou não, o Pacto de São José. ${ }^{270}$

A Corte destacou que a solicitação do México envolveria uma interpretação dos documentos conforme o conceito do artigo 31 da Convenção de Viena sobre o Direito dos Tratados de 1969, devendo-se levar em conta o sistema dentro do qual os tratados se inserem. Isso para fundamentar que os tratados internacionais de direitos humanos são instrumentos vivos, cuja interpretação deve acompanhar a evolução dos tempos bem como as condições de vida atuais. ${ }^{271}$

\footnotetext{
${ }^{269}$ Opinião Consultiva Número 16, de $1^{\circ}$ de outubro de 1999, solicitada pelo México perante à Corte Interamericana de Direitos Humanos. O direito de informação sobre a assistência consular no âmbito das garantias do Devido Processo Legal, parágrafo 26.

${ }^{270}$ Opinião Consultiva Número 16 , de $1^{\circ}$ de outubro de 1999, solicitada pelo México perante à Corte Interamericana de Direitos Humanos. O direito de informação sobre a assistência consular no âmbito das garantias do Devido Processo Legal, parágrafos 40-2 e 61 .

${ }^{271}$ Opinião Consultiva Número 16 , de $1^{\circ}$ de outubro de 1999 , solicitada pelo México perante à Corte Interamericana de Direitos Humanos. O direito de informação sobre a assistência consular no âmbito das garantias do Devido Processo Legal. Parágrafos 111 a 114. A Corte Interamericana de Direitos Humanos cita como fundamento o Parecer Consultivo expedido pela Corte Internacional de Justiça em 1971: Legal Consequences for States of the Continued Presence of South Africa in Namibia (South West Africa) notwithstanding Security Council Resolution 276 (1970), sobre a necessidade de se levar em conta a evolução do Direito; que um instrumento internacional deve ser interpretado e aplicado no marco do conjunto do sistema jurídico vigente no momento em que se pratica a interpretação. Nos últimos cinqüenta anos o domínio do corpus iuris gentium tem-se enriquecido consideravelmente. Disponível online em: <http://www.icjcij.org/docket/index.php?p1=3\&p2=4\&code=nam\&case=53\&k=a7> (acesso em 09/08/2009).
} 
A Corte Interamenticana fez referência ao entendimento da jurisprudência do Comitê de Direitos Humanos da Organização das Nações Unidas e concluiu que se os requisitos procedimentais e substantivos do devido processo não são cumpridos, condenando-se à morte um estrangeiro sem comunicar-lhe oportunamente do direito de assistência consular, então o Estado Receptor viola não apenas o artigo 14 (devido processo), mas também o artigo 6(2) (direito à vida), da Convenção Internacional sobre Direitos Civis e Políticos ${ }^{272}$. E porque a pena de morte é irreversível, exigindo do Estado que a aplica a estrita e rigorosa observância das garantias do devido processo legal, a Corte concluiu que a falha em observar o direito de um nacional estrangeiro, nos termos do artigo 36.1(b) da Convenção prejudica o devido processo legal. E, nessas circunstâncias, a imposição da pena de morte é uma violação ao direito de não ser privado da vida arbitrariamente, conforme estabelecido nos tratados internacionais mais relevantes de direitos humanos. ${ }^{273}$

A Corte concordou com a observação do México de que, muito embora a consulta se limitasse a casos sancionáveis com pena de morte, isto não excluiria a aplicação dos direitos enunciados no artigo 36 da Convenção de Viena sobre Relações Consulares de 1963 em outras condenações. O próprio dispositivo não faz nenhuma distinção com base em gravidade de uma pena aplicável ao delito que origina a detenção; não exige que se informe ao funcionário consular sobre as razões que determinaram a privação da liberdade, o que poderia ofender o direito fundamental à privacidade, tampouco se refere às razões da pena aplicável, pelo que se deduz que este direito assiste a qualquer estrangeiro que for privado de sua

\footnotetext{
272،“Artigo $6^{\circ}$. \$1. O direito à vida é inerente à pessoal humana. Este direito deverá ser protegido pela Leis. Ninguém poderá ser arbitrariamente privado de sua vida. \$2.Nos países em que a pena de morte não tenha sido abolida, esta poderá ser imposta apenas nos casos de crimes mais graves, em conformidade coma legislação vigente na época em que o crime foi cometido e que não esteja em conflito com as disposições do presente Pacto, nem com a Convenção sobre a Prevenção e a Repressão do Crime de Genocídio. Poder-se-á aplicar essa pena em decorrência de uma sentença transitada em julgado e proferida por tribunal competente. (...)"

${ }^{273}$ El Comité de Derechos Humanos de la ONU ha determinado en varios casos concernientes a la aplicación de la pena de muerte que, en caso de constatarse violaciones a las garantías del debido proceso establecidas en el artículo 14 del Pacto Internacional de Derechos Civiles y Políticos, también se viola el artículo 6.2 del mismo si la pena es ejecutada. A Opinião Consultiva cita os casos do Comitê de Direitos Humanos da ONU como o do senhor Daniel Monguya Mbenge (1983); Reid vs. Jamaica (no. 250/1987); Wright vs. Jamaica en 1992. Opinião Consultiva Número 16, de $\mathbf{1}^{\mathbf{0}}$ de outubro de 1999, solicitada pelo México perante à Corte Interamericana de Direitos Humanos. O direito de informação sobre a assistência consular no âmbito das garantias do Devido Processo Legal.Parágrafos 130-6.
} 
liberdade, de qualquer maneira, e por qualquer motivo, e não apenas em caso em que se admita a possibilidade de aplicação de pena de morte. ${ }^{274}$

Portanto, consagra o direito de assistência consular no corpo direitos humanos, entre os componentes das garantias mínimas do devido processo legal nunca uma realidade estática, mas em constante evolução - no caso de estrangeiros privados de liberdade, para a efetivação da ampla defesa, garantindo-se, afinal, um julgamento justo, equitativo e imparcial - um direito individual do preso que pode redundar em seu benefício, e corresponde a deveres correlatos do Estado Receptor onde se encontra o preso, devendo ser respeitado por todos os Estados, independentemente de sua organização interna, se federada ou unitária. ${ }^{275}$

A presença de condições de desigualdade real enfrentada pelo estrangeiro privado de liberdade obriga a adoção de "medidas de compensação" pelo Estado Receptor que o mantém custodiado, que contribuam para a redução ou eliminação dos obstáculos e deficiências que impeçam ou reduzam a defesa eficaz dos interesses próprios do acusado e o desfrute de real acesso à justiça e efetivação das garantias mínimas de um processo justo. É nesse sentido que é nomeado o tradutor para o estrangeiro que desconhece o idioma onde se desenvolve o processo criminal, e o direito de ser informado oportunamente de que pode contar com a assistência consular. Esses são meios que se complementam formando o conjunto das garantias processuais que integram o devido processo legal, consagrado no artigo 14 do Pacto Internacional dos Direitos Civis e Políticos. ${ }^{276}$

\footnotetext{
${ }^{274}$ Opinião Consultiva Número 16 , de $1^{\circ}$ de outubro de 1999 , solicitada pelo México perante à Corte Interamericana de Direitos Humanos. $O$ direito de informação sobre a assistência consular no âmbito das garantias do Devido Processo Legal. Parágrafos 100 e 101.

${ }^{275}$ Para Christina CERNA, o status de "direito humano" é maior que o de um direito individual encontrado em um tratado internacional particular. Para que o direito de notificação sobre assistência consular adquirir o status de "direito humano", como componente do direito fundamental das garantias mínimas do devido processo para um julgamento justo, por exemplo, entraria na questão da legitimidade do julgamento final numa jurisdição estrangeira. Se o direito consular é um direito humano, porder-se-ía esperar que a obrigação do Estado receptor de realmente garantir ao estrangeiro assistência consular seria mais do que um direito discricionário. CERNA, Christina Monica. The Right to Consular Notification as a Human Right, p. 421.

${ }^{276}$ Decreto n. ${ }^{\circ}$ 592, de 6 de julho de 1992 que promulga o Pacto Internacional sobre Direitos Civis e Políticos. Artigo 14. "I. Todas as pessoas são iguais perante os tribunais e as cortes de justiça. Toda pessoa terá o direito de ser ouvida publicamente e com as devidas garantias por um tribunal competente, independente e imparcial, estabelecido por lei, na apuração de qualquer acusação de
} 
Finalmente, a Corte interpretou, unanimemente, pela crucial importância da expressão "sem tardar" do artigo 36, 1(b) da Convenção, que requer que as autoridades do Estado Receptor devem informar aos detidos estrangeiros sobre seu direito à assistência consular no momento da privação da liberdade, e sempre antes que de qualquer declaração por parte do acusado estrangeiro ou confissão perante a autoridade policial ou judicial.

Em voto concordante, CANÇADO TRINDADE asseverou que o direito à assistência consular não pode hoje ser apreciado no âmbito das relações exclusivamente inter-Estatais, e que a Opinião Consultiva leva em consideração a cristalização do direito de informação sobre a assistência consular no tempo, e a sua vinculação com os direitos humanos. Para ele, não há mais como pretender dissociar o direito de informação sobre a assistência consular do corpus juris dos direitos

caráter penal formulada contra ela ou na determinação de seus direitos e obrigações de caráter civil. A imprensa e o público poderão ser excluídos de parte ou da totalidade de um julgamento, que por motivo de moral pública, de ordem pública ou de segurança nacional em uma sociedade democrática, quer quando o interesse da vida privada das partes o exija, quer na medida em que isso seja estritamente necessário na opinião da justiça, em circunstâncias específicas, nas quais a publicidade venha a prejudicar os interesses da justiça; entretanto, qualquer sentença proferida em matéria penal ou civil deverá tornar-se pública, a menos que o interesse de menores exija procedimento oposto, ou o processo diga respeito a controvérsia matrimoniais ou á tutela de menores. 2. Toda pessoa acusada de um delito terá direito a que se presuma sua inocência enquanto não for legalmente comprovada sua culpa. 3. Toda pessoa acusada de um delito terá direito, em plena igualdade, a, pelo menos, as seguintes garantias: a) de ser informado, sem demora, numa língua que compreenda e de forma minuciosa, da natureza e dos motivos da acusação contra ela formulada; b) de dispor do tempo e do meios necessários à preparação de sua defesa e a comunicar-se com defensor de sua escolha; c) de ser julgado sem dilações indevidas; d) de estar presente no julgamento e de defender-se pessoalmente ou por intermédio de defender de sua escolha; de ser informado, caso não tenha defensor, do direito que lhe assiste de tê-lo e, sempre que o interesse da justiça assim exija, de ter um defensor designado "ex offício" gratuitamente, se não tiver meios para remunerá-lo; e) de interrogar ou fazer interrogar as testemunhas da acusação e de obter o comparecimento e o interrogatório das testemunhas de defesa nas mesmas condições de que dispõe as de acusação; f) de ser assistida gratuitamente por um intérprete, caso não compreenda ou não fale a língua empregada durante o julgamento; g) de não ser obrigada a depor contra si mesma, nem a confessar-se culpada. 4. $O$ processo aplicável a jovens que não sejam maiores nos termos da legislação penal levará em conta a idade dos menores e a importância de promover sua reintegração social. 5. Toda pessoa declarada culpada por um delito terá o direito de recorrer da sentença condenatória e da pena a uma instância, em conformidade com a lei. 6 . Se uma sentença condenatória passada em julgado for posteriormente anulada ou se indulto for concedido, pela ocorrência ou descoberta de fatos novos que provem cabalmente a existência de erro judicial, a pessoa que sofreu a pena decorrente dessa condenação deverá ser indenizada, de acordo com a lei, a menos que fique provado que se lhe pode imputar, total ou parcialmente, não-revelação dos fatos desconhecidos em tempo útil. 7. Ninguém poderá ser processado ou punido por um delito pelo qual já foi absolvido ou condenado por sentença passada em julgado, em conformidade com a lei e os procedimentos penais de cada país." Opinião Consultiva Número 16 , de $1^{\circ}$ de outubro de 1999, solicitada pelo México perante à Corte Interamericana de Direitos Humanos. $O$ direito de informação sobre a assistência consular no âmbito das garantias do Devido Processo Legal, pars. 117-120. 
humanos. É assim que o atual Juiz da Corte Internacional de Justiça considera ser a Convenção de Viena sobre Relações Consulares de 1963 um tratado internacional de direitos humanos, com todas suas peculiaridades.

Por sua vez, o JuIz SÉRgIo GARCÍA RAMÍREZ afirmou que o indiciado é titular dos direitos e garantias, que são o escudo do cidadão diante do poder arbitrário. O direito à defesa no processo tem-se visto ampliado e enriquecido. ${ }^{277} \mathrm{Os}$ estrangeiros submetidos ao procedimento penal - em especial, mesmo que não exclusivamente, quando se vêm privados da liberdade - devem contar com meios que lhes permitam um verdadeiro e pleno acesso à justiça. Não basta, portanto, que a lei reconheça aos estrangeiros os mesmos direitos que dos demais indivíduos nacionais do Estado em que segue o procedimento criminal, mas também é necessário que esses direitos se agreguem em pé de igualdade perante a justiça, sem as graves limitações que implicam a estranheza cultural, a ignorância do idioma, o desconhecimento do meio e outras restrições reais das suas possibilidades de defesa.

E mais, afirmou que os direitos e garantias que integram o devido processo não representam uma realidade estática esgotada, mas sim um sistema dinâmico, em constante formação, e que somente é possível chegar a uma sentença justa, garantida pela justiça de uma sociedade democrática, quando forem lícitos os meios processuais utilizados. É que não é possível sustentar que há um devido processo quando o processo não se desenvolve num tribunal competente, independente, imparcial, ou se o sujeito submetido ao ordenamento processualcriminal desconhece a imputação que lhe é feita, e não for possível apresentar provas e bem formular a sua defesa. E se o direito de informação sobre assistência consular já forma parte do conjunto de direitos e garantias integrantes do devido processo, é evidente que a sua violação resulta nas consequiências: nulidade $e$ responsabilidade. ${ }^{278}$

\footnotetext{
277 Opinión Consultiva OC-16/99 del 1 de octubre de 1999. El Derecho a la Información sobre la Asistencia Consular en el Marco de las Garantías del Debido Proceso Legal, Voto concordante do JUIZ SÉRGIO GARCIA RAMIREZ, pp. 01-03.

${ }^{278}$ Opinión Consultiva OC-16/99 del 1 de octubre de 1999. El Derecho a la Información sobre la Asistencia Consular en el Marco de las Garantías del Debido Proceso Legal. Voto concordante do JUIZ SÉRGIO GARCIA RAMIREZ, p. 03.
} 


\subsection{Os efeitos causados pela Opinião Consultiva $n^{\circ} 16$ da Corte Interamericana de Direitos Humanos na esfera das Organizações Internacionais e no âmbito jurídico interno dos Estados}

Para Christina M. CERnA ${ }^{279}$, a Opinião Consultiva n.$^{\circ} 16$ da Corte Interamericana de Direitos Humanos é "surpreendentemente ousada", pelo alcance que atinge, sobretudo porque, na ocasião em que foi solicitada, existiam casos semelhantes na Corte Internacional de Justiça.

A Corte Interamericana reconheceu que os direitos conferidos pelo artigo 36 da Convenção de Viena sobre Relações Consulares aplicam-se a todos os casos em que um nacional de um Estado que envia esteja privado de liberdade, independentemente da razão ou gravidade do crime cometido. ${ }^{280}$ É nesse sentido que, para CANÇADO TRINDADE ${ }^{281}$, é "verdadeiramente pioneira e histórica”, servindo de inspiração para os casos internacionais e domésticos sobre a matéria, revelando o impacto do Direito Internacional dos Direitos Humanos na evolução do próprio Direito Internacional contemporâneo. Foi mencionada nos casos LAGRAND e AvenA, da Corte Internacional de Justiça, nas fases orais e escritas. Da mesma forma, foi pronta e expressamente referida pela Assembléia Geral da Organização das Nações Unidas, em Resoluções sobre a proteção de imigrantes ${ }^{282}$; pela Comissão

279 CERnA, Christina Monica. The Right to Consular Notification as a Human Right for the Medellin Symposium, p. 431. Ela refere-se aos casos apresentados perante a Corte Internacional de Justiça em 1998 e 1999, respectivamente por Paraguai (BREARD) e Alemanha (LAGRAND), contra os Estados Unidos, por violação da Convenção de Viena sobre Relações Consulares de 1963, objetos de estudo deste trabalho.

${ }^{280}$ Opinião Consultiva Número 16 , de $1^{\circ}$ de outubro de 1999, solicitada pelo México perante à Corte Interamericana de Direitos Humanos. O direito de informação sobre a assistência consular no âmbito das garantias do Devido Processo Legal. Pará. 101: "la respuesta que la Corte ofrezca a esta parte de la consulta, es aplicable a todos los casos en que un nacional del Estado que envía es privado de libertad por cualesquiera motivos, y no únicamente por hechos que, al ser calificados por la autoridad competente, podrían involucrar la aplicación de la pena de muerte".

281 "This Advisory Opinion No. 16 of the IACtHR, truly pioneering, has served as inspiration for the emerging international case-law, in statu nascendi, on the matter, and is having a sensible impact on the practice of the States (infra) of the region on the issue. The Advisory Opinion achieved a considerable mobilization in the advisory proceedings (with eight intervening States, besides several non-governmental organizations and individuals), one of the greatest in the whole history of the Court to date, surpassed only by that in the subsequent Advisory Opinion No. 18 of the IACtHR on the Juridical Condition and Rights of Undocumented Migrants (2003)." CANÇADO TRINDADE, Antônio Augusto. The Humanization of Consular Law: The Impact of Advisory Opinion No. 16 (1999) of the Inter-American Court of Human Rights on International Case-Law and Practice, pp. 08-10. ${ }^{282}$ Pela Resolução de n. ${ }^{\circ}$ 54/166, de 17 de dezembro de 1999: "A/RES/54/166, 24 February 2000, Protection of Migrants: (...) Taking note of the decisions of the relevant international juridical bodies 
de Direitos Humanos da Organização das Nações Unidas ${ }^{283}$; e pela Organização dos Estados Americanos. ${ }^{284}$

\section{CANÇADO TRINDADE ${ }^{285}$ duvida se à época em que a Convenção de}

Viena sobre Relações Consulares foi adotada e entrou em vigor, suas disposições diziam respeito estritamente às relações inter-Estatais. Ele lembrou que duas décadas após a Convenção entrar em vigor, a Convenção foi relacionada pelos direitos aos direitos fundamentais inerentes às pessoas humanas pelos próprios Estados Unidos,

on questions relating to migrants, particularly advisory opinion OC-16/99, issued by the InterAmerican Court of Human Rights on 1 October 1999, regarding the right to information about consular assistance within the framework of due process guarantees, (...). Assim como pela 55/92 de 04 de dezembro de 2000 A/RES/55/92, 26 February 2001. (...) Taking note of the decisions of the relevant international juridical bodies on questions relating to migrants, in particular advisory opinion OC-16/99, issued by the Inter-American Court of Human Rights on 1 October 1999, regarding the right to information about consular assistance within the framework of due process guarantees, (...)". In: CANÇADO TRINDADE, Antônio Augusto. The Humanization of Consular Law: The Impact of Advisory Opinion No. 16 (1999) of the Inter-American Court of Human Rights on International Case-Law and Practice, p. 10.

${ }^{283}$ Human rights of migrants. Commission on Human Rights resolution 2001/52. (...) Noting advisory opinion OC-16/99 of 1 October 1999 issued by the Inter-American Court of Human Rights regarding the right to information about consular assistance within the framework of the guarantees of due process of law, in the case of foreign nationals detained by the authorities of a receiving State, (...) .In: CANÇADO TRINDADE, Antônio Augusto. The Humanization of Consular Law: The Impact of Advisory Opinion No. 16 (1999) of the Inter-American Court of Human Rights on International Case-Law and Practice, p. 10. Ele ressalta ainda que em 08 de agosto de 2002, a Subcomissão de Promoção e Proteção dos Direitos Humanos da ONU, insistiu aos Estados Unidos da América que suspendesse a execução do mexicano JOSÉ ERNESTO MEDELLín, com base na Opinião Consultiva n. ${ }^{\circ}$ 16/1999 da Corte Interamericana de Direitos Humanos, no curso do caso AvenA, da Corte Internacional de Justiça. In: Idem, p. 10.

${ }^{284}$ AG/RES. 1717 (XXX-O/00) - "Os direitos humanos de todos os trabalhadores migrantes e de suas famílias", (Aprovada na primeira sessão plenária, realizada em 5 de junho de 2000). Considerando (...) O Parecer Consultivo OC-16, emitido pela Corte Interamericana de Direitos Humanos, relativo ao direito de informação sobre a assistência consular, no âmbito do devido processo judicial, nos casos de estrangeiros detidos por autoridades do Estado receptor;(...). E AG/RES. 1775 (XXXI-O/01), "Os direitos humanos de todos os trabalhadores migrantes e de suas famílias", (Aprovada na terceira sessão plenária, realizada em 5 de junho de 2001). Considerando (...) O Parecer Consultivo OC-16, emitido pela Corte Interamericana de Direitos Humanos, relativo ao direito de informação sobre a assistência consular, no âmbito do devido processo judicial, nos casos de estrangeiros detidos por autoridades do Estado receptor; (...)". In: CANÇADO TRINDADE, Antônio Augusto. The Humanization of Consular Law: The Impact of Advisory Opinion No. 16 (1999) of the Inter-American Court of Human Rights on International Case-Law and Practice, p. 10 .

${ }_{285}^{28}$ Da mesma forma a Convenção de Viena sobre Relações Diplomáticas de 1961. CANÇADO TRINDADE, Antônio Augusto. The Humanization of Consular Law: The Impact of Advisory Opinion No. 16 (1999) of the Inter-American Court of Human Rights on International CaseLaw and Practice, p. 03. 
lembrando, por exemplo, o "caso dos Refén de Teerã” apresentado pelos Estados Unidos da América contra o Irã, perante a Corte Internacional de Justiça em 1979. ${ }^{286}$

Em julgamento do dia 24 de maio de 1980 do referido caso Teerã da Corte Internacional de Justiça, referindo-se ao Direito Internacional que governa as relações diplomáticas e consulares, a Corte Internacional de Justiça sentiu-se obrigada a chamar atenção a "toda comunidade internacional" "para o dano irreparável que pode ser causado por eventos do tipo que está agora perante a Corte. Esses eventos não podem deixar de prejudicar o edifício do Direito, cuidadosamente construído pelo homem ao longo de um período de séculos, cuja manutenção é vital para a segurança e o bem-estar da complexa comunidade internacional dos dias de hoje, para a qual é mais essencial do que nunca que as regras desenvolvidas para garantir o progresso ordenado das relações entre seus membros deve ser constante e escrupulosamente respeitada." 287

Duas semanas após a adoção da Opinião Consultiva n. ${ }^{\circ}$ 16, o Ministro das Relações Exteriores do México editou uma nota circular para todos os postos consulares e diplomáticos pontuando a importância do seu devido cumprimento. ${ }^{288} \mathrm{O}$

\footnotetext{
${ }^{286}$ International Court of Justice. United States Diplomatic and Consular Staff in Tehran (United States of America v. Iran). Case concerning U.S. Diplomatic and Consular Law in Tehran.

${ }^{287}$ International Court of Justice. United States Diplomatic and Consular Staff in Tehran (United States of America v. Iran). Case concerning U.S. Diplomatic and Consular Law in Tehran. Report of Judgement (1980), p. 43, parágrafo 92.

${ }^{288}$ In: CANÇADO TRINDADE, Antônio Augusto. The Humanization of Consular Law: The Impact of Advisory Opinion No. 16 (1999) of the Inter-American Court of Human Rights on International Case-Law and Practice, p. 12. Destacamos ainda a Intervenção do Ministro das Relações Exteriores do México, Embaixador Juan Manuel Gómez Robledo, na 56 Assembléia Geral da ONU (2001), em "Informe da Corte Internacional de Justiça" em que expressou que gostaria que a Corte Internacional de Justiça, no julgamento do caso AVENA, estabelecesse de maneira inequívoca, como a Corte Interamericana de Direitos Humanos o fizera na Opinião Consultiva n.o 16/1999, de que os direitos conferidos pelo artigo 36.1(b) da Convenção de Viena sobre Relações Consulares de 1963 compõem o rol dos direitos humanos, porque isso resultaria em maior relevância. In: Intervención del Embajador Juan Manuel Gómez Robledo, consultor jurídico de la Secretaría de Relaciones Exteriores de México, en el marco del tema 13 del Programa de Trabajo de la 56 ${ }^{\mathrm{a}}$. Asamblea General de las Naciones Unidas: "informe de la Corte Internacional de Justicia. Nueva York, 30 de octubre de 2001. (...) "b) Respecto del alcance de las obligaciones contenidas en el artículo 36, párrafo 1, de la Convención de Viena sobre Relaciones Consulares, la Corte determina que dicho numeral confiere también derechos individuales. México apoya esta conclusión. Al mismo tiempo, hubiéramos preferido que la Corte se pronunciara sobre todas las cuestiones que fueron sometidas a su consideración en relación con este tema específico, y definiera de manera inequívoca que los derechos contenidos en el artículo 36, párrafo 1 de la Convención antes citada, tienen el carácter de derechos humanos. Esta cuestión ya ha sido considerada en otros foros, entre ellos la Corte Interamericana de Derechos Humanos en su opinión consultiva OC-16, y existen elementos firmes en el derecho internacional que permiten
} 
Ministério das Relações Exteriores de El Salvador - país que tem expressivo número de seus nacionais residindo em territótio norte-americano - editou mensagens circulares em 16 de julho de 1998 e em 08 de dezembro de 1999 a todos os seus postos consulares e diplomáticos, salientando o dever de cumprimento pelo Estado Receptor, do artigo 36 da Convenção de Viena sobre Relações Consulares de 1963, e resumindo o conteúdo da Opinião Consultiva em questão, instruindo-os a cumprir com os deveres do Estado salvadorenho de proteger seus nacionais privados de liberdade no exterior. ${ }^{289}$ A Constituição da República Bolivariana da Venezuela, data da de 1999, inseriu o dever de se observar a "notificação consular prevista nos tratados internacionais sobre a matéria" no caso da prisão de estrangeiros. ${ }^{290}$

reafirmar tal conclusión. Un pronunciamiento de la Corte sobre este tema hubiera resultado de gran relevancia. Sin embargo, el hecho de que no haya entrado a su discusión, en nada modifica el carácter de derecho humano que otros órganos ya han conferido al artículo 36, párrafo 1 de la Convención de Viena.(...)". Disponível online em: http://www.un.int/mexico/2001/56AGONU/interv_56ag103001t13.htm> (acesso em 14/08/2009). De maneira geral, observamos que a Opinião Consultiva n. 16 também foi citada nos casos Valdez Medina, MA Flores G. Valdez Mattos, Suarez Medina, outros mexicanos condenados à pena de morte sem terem recebido informação sobre o direito à assistência consular, nos Estados Unidos, em que países como Argentina, Honduras, Polônia, Espanha, Uruguai, Brasil, Chile, Consta Rica, El Salvador, Islândia, Venezuela, Panamá, e inclusive o Brasil, manifestaram apoio à Opinião Consultiva n. ${ }^{\circ}$ 16/1999, no sentido de que a privação do direito à vida em desacordo com a Convenção de Viena sobre Relações Consulares prejudicaria as garantias do devido processo legal a assegurar um julgamento justo, resultando na privação arbitrária do direito à vida, em violação com o artigo $6^{\circ}$ da Convenção da ONU sobre Direitos Civis e Políticos, pedindo clemência às autoridades responsáveis, por meio de cartas e Amicus Curie (caso J. Juarez Medina). In: CANÇADO TRINDADE, Antônio Augusto. The Humanization of Consular Law: The Impact of Advisory Opinion No. 16 (1999) of the Inter-American Court of Human Rights on International Case-Law and Practice, p. 12.

${ }^{289}$ Da mesma forma o Peru, que consultou à Polícia Nacional sobre o cumprimento com o direito de informação sobre assistência consular a estrangeiros, respondendo positivamente, em 31 de dezembro de 2001. Na mesma linha, os Ombudsman (Defensor dos Habitantes), da Costa Rica, preocupado com as constantes deportações de costa-riquenhos no Panamá, editou um comunicado em 02 de novembro de 2001, recomendando às autoridades nacionais o pronto exercício da proteção consular, à luz da Opinião Consultiva n. ${ }^{\circ} 16$ da Corte Interamericana de Direitos Humanos. In: CANÇADO TRINDADE, Antônio Augusto. The Humanization of Consular Law: The Impact of Advisory Opinion No. 16 (1999) of the Inter-American Court of Human Rights on International Case-Law and Practice, p. 14.

290 "Constitución de la República Bolivariana de Venezuela (Publicada en Gaceta Oficial del jueves 30 de diciembre de 1999, Número 36.860). Artigo 44.2. 2. Toda persona detenida tiene derecho a comunicarse de inmediato con sus familiares, abogado o abogada o persona de su confianza, y éstos o éstas, a su vez, tienen el derecho a ser informados o informadas del lugar donde se encuentra la persona detenida, a ser notificados o notificadas inmediatamente de los motivos de la detención y a que dejen constancia escrita en el expediente sobre el estado físico y psíquico de la persona detenida, ya sea por sí mismos o con el auxilio de especialistas. La autoridad competente llevará un registro público de toda detención realizada, que comprenda la identidad de la persona detenida, lugar, hora, condiciones y funcionarios que la practicaron. Respecto a la detención de extranjeros o extranjeras se observará, además, la notificación consular prevista en los tratados internacionales sobre la materia." A previsão foi mantida na Constituição reeditada em fevereiro de 2007. CANÇADO TRINDADE salienta que, no entanto, o Ministério das Relações Exteriores da Venezuela, por anos, foi atento à questão à questão da assistência consular para seus nacionais detidos no exterior. In: CANÇADo TRIndade, Antônio Augusto. The Humanization of Consular Law: The Impact of 
Outros exemplos de prática internacional que sofreram influência da Opinião Consultiva n. ${ }^{0} 16$ de 1999 relacionam-se ao Brasil. É o caso do I Encontro Ibérico da Comunidade de Brasileiros no Exterior, ocorrido em Lisboa entre os dias de 09 a 11 de maio de 2002, promovido pela Procuradoria Regional dos Direitos do Cidadão do Distrito Federal, órgão do Ministério Público Federal. O documento final resultante contemplou o estabelecimento de um esquema de assessoria jurídica no exterior para imigrantes brasileiros, financiado pelo governo brasileiro, para o fim de garantir-lhes a condição de titulares de direitos fundamentais. ${ }^{291}$

O Ministério das Relações Exteriores do Brasil editou em 06 de junho de 2000 o Manual de Serviço Consular e Jurídico, que se refere à Convenção de Viena sobre Relações Consulares de 1963, cujos preceitos podem ser invocados “ainda que em país não-signatário da Carta das Nações Unidas ou da Convenção”. ${ }^{292}$ Em 2010, foi feita ampla revisão do Manual do Serviço Consular e Jurídico, tendo

Advisory Opinion No. 16 (1999) of the Inter-American Court of Human Rights on International Case-Law and Practice, p.13.

${ }^{291} \mathrm{O}$ documento também defendeu o envolvimento direto das Embaixadas nas questões políticas, sociais, jurídicas e econômicas relacionadas aos imigrantes. Assim como o fortalecimento da estrutura dos Consulados, com reforço das capacidades humanas e financeiras dos consulados para o devido atendimento aos brasileiros no exterior, com a ampliação do número de funcionários; terceirização de mão-de-obra em situações de emergência; identificação das necessidades de capacitação e credenciamento de entidades que possam realizá-la e integração do Ministério das Relações Exteriores com órgãos federais competentes (Secretaria da Receita Federal, Justiça Eleitoral, etc.), para identificação das necessidades de treinamento. Projeto Brasileiros no Exterior. I Encontro Ibérico da Comunidade de Brasileiros no Exterior. Documento de Lisboa. Lisboa, 9 a 11 de Maio de 2002. Documento disponível online em:<http://www.portal.ecclesia.pt/instituicao/pub/23/img/encontro_iberico_brasil02.pdf> (acesso em 18/08/2009). Cita-se ainda o exemplo de El Salvador, Guatemala e Nicarágua , em 30 de novembro de 2000, tornando-se efetivo em 01 de janeiro de 2001, estabeleceram juntos um "Mecanismo de Proteção Consular Trinacional", concordando em prover proteção consular pelos Cônsules em cada Estado, sempre que esses não tivessem Cônsules atuando no Estado Receptor, em caso de emergência e necessidade. O Ministério das Relações Exteriores do Chile editou em 2001 um manual de procedimento para o pleno exercício da assistência e proteção consular e diplomática, reconhecendo o dever de o Estado Receptor de informar aos Cônsules do Chile a detenção de um nacional chileno, e seus direitos previstos pelo artigo 36(1) da Convenção de Viena sobre Relações Consulares de 1963, à luz dos direitos fundamentais da pessoa humana. In: CANÇADO TRINDADE, Antônio Augusto. The Humanization of Consular Law: The Impact of Advisory Opinion No. 16 (1999) of the InterAmerican Court of Human Rights on International Case-Law and Practice, p.13. O II ENCONTRO DE BRASILEIRAS E BRASILEIROS NO EXTERIOR ocorreu entre os dias 30 de novembro, 1 e 2 de dezembro de 2007, na Bélgica, e resultou no DOCUMENTO DE BRUXELAS, com várias solicitações. Teve como principal objetivo a criação de uma Rede de Organizações que trabalham com cidadãs e cidadãos brasileiros na Europa. Desta vez, não teve participação de representantes do Ministério das Relações Exteriores.

${ }^{292}$ República Federativa do Brasil. Ministério das Relações Exteriores. Diretoria-Geral de Assuntos Consulares, Jurídicos e de Assistência a Brasileiros no Exterior. Manual de Serviço Consular e Jurídico. Tomo I. Capítulo 3․ Assistência e Proteção a Brasileiros. Item 3.1.23: "Caberá igualmente à Autoridade Consular, no exercício do que lhe faculta o artigo 36 da Convenção de Viena sobre 
como um dos objetivos simplificar os atos consulares; sua atualização é permanente, ocorrendo cada vez que se identifica possibilidade de aperfeiçoamento. No tocante à simplificação, cumpre mencionar que algumas regras não dependem exclusivamente do Itamaraty, sendo afetas a outros órgãos do Governo, tais como Comando do Exército (incorporação militar), Justiça Eleitoral (título de eleitor e votação), Polícia Federal (passaportes), Receita Federal (CPF) e outros. Iniciou-se ainda esforço de padronização das informações constantes dos sítios eletrônicos dos postos, o que já ocorreu no tocante ao registro consular de nascimento, casamento e óbito. Esse esforço prosseguirá em 2011, com o objetivo de padronizar as informações sobre os demais serviços.

\subsection{A Opinião Consultiva Número 16, de $1^{\circ}$ de outubro de 1999, e seus efeitos no ordenamento jurídico brasileiro}

O Brasil sofre influência direta da competência consultiva da Corte Interamericana de Direitos Humanos desde que a aderiu à Convenção Americana, em 25 de setembro de 1992. O reconhecimento do Brasil da competência obrigatória da Corte Interamericana de Direitos Humanos, no entanto, foi aprovada pelo Congresso Nacional por força do Decreto Legislativo $\mathrm{n}^{0}$ 89, de 03 de dezembro de 1998. Mas foi o Decreto Presidencial $n^{\circ} .4 .463$ de 8 de novembro de 2002, que finalmente promulgou a Declaração de Reconhecimento da Competência Obrigatória da Corte Interamericana de Direitos Humanos, sob reserva de reciprocidade, em consonância com o artigo 62 da Convenção Americana sobre Direitos Humanos.

Relações Consulares: 1) prestar assistência aos brasileiros que se acharem envolvidos em processos criminais; 2) estabelecer contatos com diretores de penitenciárias situadas em sua jurisdição $e$ manter relação atualizada de presos brasileiro e andamento dos seus respectivos processos; 3) caso solicitado, servir de ligação entre os prisioneiros e suas famílias, seja no Brasil ou no exterior; 4) nos postos onde é elevado o número de prisioneiros brasileiros, inteirar-se das condições de saúde e das instalações onde estejam detidos $e$, ainda, instruir funcionário a visitar periodicamente os prisioneiros, mantendo fichário atualizado e enviando relatórios periódicos; e 5) assegurar, na medida do possível, aos brasileiros detidos ou encarcerados, acesso aos serviços consulares." Disponível online em: <http://www.casadobrasil.info/UserFiles/File/pdfs/manconsular.pdf> (acesso em: 18/08/2009). 
Diante disso, os órgãos judiciais internos do Brasil devem recepcionar essas Opiniões Consultivas de modo a evitar futura responsabilização internacional por violações da Convenção Americana sobre Direitos Humanos, pela Corte Interamericana. Certamente, seria muito difícil para o Brasil justificar perante a comunidade interamericana a manutenção de uma interpretação de direito doméstico quando a Corte Interamericana houver se manifestado em contrário em sede consultiva. $^{293}$

NADIA DE ARAÚJO chama atenção para a influência que devem ter as Opiniões Consultivas da Corte Interamericana de Direitos Humanos no Direito brasileiro. Ela explica que, em decorrência da vigência da Convenção Americana de Direitos Humanos, aplicada seguidamente pelos tribunais brasileiros, além da aceitação da jurisdição obrigatória da Corte, pelo Brasil (para fatos ocorridos a partir do reconhecimento), "é imperioso respeitar as Opiniões Consultivas", na medida em que essas "esclarecem a correta interpretação da Convenção e precisam ser levadas em conta na hora da aplicação da Convenção no ordenamento jurídico nacional". ${ }^{294}$

${ }^{293}$ RAMOS, André de Carvalho. Direitos humanos em juízo, pp. 348-9.

${ }^{294}$ ARAÚJO, Nadia de. A influência das opiniões consultivas da Corte Interamericana de Direitos Humanos no ordenamento jurídico brasileiro..., p. 229. Este trabalho encontra-se disponível online, mas foi publicado em junho de 2005, pela Revista da Faculdade de Direito de Campos, Ano VI, n. ${ }^{\circ}$ 6. Mostra apenas as Opiniões n. ${ }^{\circ} 5$, sobre o registro da profissão de jornalistas, e na de n. ${ }^{\circ} 16$, sobre assistência consular -, e suas conseqüências para o direito brasileiro. O estudo demonstra a necessidade de se fazer um trabalho prospectivo também com relação às demais opiniões consultivas da Corte Interamericana de Direitos Humanos. Citamos como exemplo de menção à Convenção Interamericana de Direitos Humanos, entre os diversos, trechos de ementas do Supremo Tribunal Federal: 1) RE 349703 / RS - Rio Grande do Sul. "Prisão civil do depositário infiel em face dos tratados internacionais de direitos humanos. Interpretação da parte final do inciso LXVII do artigo 5 o da constituição brasileira de 1988. Posição hierárquico-normativa dos tratados internacionais de direitos humanos no ordenamento jurídico brasileiro. Desde a adesão do Brasil, sem qualquer reserva, ao Pacto Internacional dos Direitos Civis e Políticos (artigo 11) e à Convenção Americana sobre Direitos Humanos - Pacto de San José da Costa Rica (artigo 7º, 7), ambos no ano de 1992, não há mais base legal para prisão civil do depositário infiel, pois o caráter especial desses diplomas internacionais sobre direitos humanos lhes reserva lugar específico no ordenamento jurídico, estando abaixo da Constituição, porém acima da legislação interna. O status normativo supralegal dos tratados internacionais de direitos humanos subscritos pelo Brasil torna inaplicável a legislação infraconstitucional com ele conflitante, seja ela anterior ou posterior ao ato de adesão." 2) HC 88420 I PR - Paraná: "V - Ainda que não se empreste dignidade constitucional ao duplo grau de jurisdição, trata-se de garantia prevista na Convenção Interamericana de Direitos Humanos, cuja ratificação pelo Brasil deu-se em 1992, data posterior à promulgação Código de Processo Penal. VI - A incorporação posterior ao ordenamento brasileiro de regra prevista em tratado internacional tem o condão de modificar a legislação ordinária que lhe é anterior. VII - Ordem concedida." Outro exemplo é o HC 94013 / SP - São Paulo: "3. O Pacto de San José da Costa Rica (ratificado pelo Brasil - Decreto 678 de 6 de novembro de 1992), para valer como norma jurídica interna do Brasil, há de ter como fundamento de validade o $\$ 2^{\circ}$ do artigo $5^{\circ}$ da Magna Carta. A se contrapor, então, a qualquer norma ordinária originariamente brasileira que preveja a prisão civil por dívida. Noutros 
Os efeitos da Opinião Consultiva n. ${ }^{\circ} 16$ no ordenamento jurídico brasileiro já foram alvo de questionamento, por Professor ANDRÉ DE CARVALHO RAMOS, sobre como seriam recepcionados pelos tribunais brasileiros, de modo a evitar a responsabilização internacional do Brasil. ${ }^{295}$

No uso de suas atribuições de Procurador da República, ANDRÉ DE CARVAlHo RAmos expediu Recomendação à Polícia Federal brasileira para que, nos casos de prisão de estrangeiro no Brasil, o detido fosse notificado sobre o direito de informação sobre assistência consular, com o registro já no auto de prisão em flagrante, para ciência das demais autoridades. O argumento do Ministério Público Federal foi que esta notificação decorria da obrigação assumida pelo Brasil disposta no artigo 36 da Convenção de Viena sobre Relações Consulares de 1963.

Outro ponto enfatizado pela Recomendação foi a interpretação da Corte Interamericana que considerou o cumprimento do artigo 36 da Convenção de Viena como sendo um corolário do princípio de respeito à dignidade da pessoa humana. O Procurador da República afirma expressamente assim sobre o parecer consultivo da Corte Interamericana: ${ }^{296}$

\footnotetext{
"Considerando que a Corte Interamericana de Direitos Humanos emitiu o Parecer Consultivo n. $16 \mathrm{em} 11$ de novembro de 1999, no qual determinou que o artigo 36 da Convenção de Viena sobre Relações Consulares de 1963 reconhece ao detido estrangeiro direitos individuais, entre os quais o direito subjetivo a ser informado sobre a assistência de seu Consulado (parágrafo primeiro do dispositivo do Parecer, por unanimidade); considerando que no citado Parecer Consultivo $n^{\circ}$ 16, a Corte Interamericana de Direitos Humanos estabeleceu que o direito à notificação da assistência consular integra o devido processo legal penal (parágrafo sétimo do dispositivo do Parecer); considerando que no citado Parecer Consultivo $n^{\circ}$ 16, a Corte Interamericana de Direitos Humanos estabeleceu que a expressão "sem tardar" utilizada no artigo 36.1.(b) da Convenção de Viena sobre Relações Consulares de 1963 significa que o Estado deve cumprir com seu dever de informar o detido sobre o direito à assistência consular no momento de sua privação de
}

termos: o Pacto de San José da Costa Rica, passando a ter como fundamento de validade o $\S 2^{\circ}$ do artigo $5^{\circ}$ da CF/88, prevalece como norma supralegal em nossa ordem jurídica interna e, assim, proíbe a prisão civil por dívida. Não é norma constitucional -- à falta do rito exigido pelo $\S 3^{\circ}$ do artigo $5^{\circ}--$, mas a sua hierarquia intermediária de norma supralegal autoriza afastar regra ordinária brasileira que possibilite a prisão civil por dívida."

${ }^{295}$ RAMOS, André de Carvalho. Direitos humanos em juízo..., p. 348

${ }^{296}$ O texto da Recomendação está disponível em: ARAÚJO, Nadia de. A influência das opiniões consultivas da Corte Interamericana de Direitos Humanos no ordenamento jurídico brasileiro... Nota de rodapé n. 28. 
liberdade e em todo caso antes de todo depoimento perante autoridade pública (parágrafo terceiro do dispositivo do Parecer, unanimidade); considerando que no citado Parecer Consultivo . $^{\circ}$ 16, a Corte Interamericana de Direitos Humanos estabeleceu que as disposições internacionais que concernem a proteção de direitos humanos, inclusive a consagrada no artigo 36.1.(b) da Convenção de Viena sobre Relações Consulares de 1963, devem ser respeitadas pelos Estados, independentemente de sua estrutura federal ou unitária (parágrafo oitavo do Parecer)."

A Convenção Americana de Direitos Humanos está em vigor no ordenamento jurídico interno brasileiro e, conforme entendimento do Supremo Tribunal Federal, com hierarquia supralegal, ou seja, estando abaixo da Constituição, porém acima da legislação interna. Esse status normativo supralegal dos tratados internacionais de direitos humanos em vigor no Brasil torna inaplicável a legislação infraconstitucional com eles conflitantes conforme o $\S 2^{\circ}$ do artigo $5^{\circ}$ da $\mathrm{CF} / 88$. E tendo o Brasil reconhecido a jurisdição compulsória da Corte Interamericana de Direitos Humanos, é imperioso respeitar as interpretações dadas por meio das Opiniões Consultivas, devendo ser conhecidas e utilizadas pelos operadores jurídicos brasileiros. Atuando assim, em conformidade com a interpretação da Corte Interamericana, a qual se submete, o Brasil evita eventual futura responsabilização internacional por violação da Convenção Americana sobre Direitos Humanos. ${ }^{297}$

\footnotetext{
${ }^{297}$ Cita-se apenas um dos diversos exemplos de jurisprudência do Supremo Tribunal Federal que trata da hierarquia especial do Pacto de São José no Direito brasileiro. "Direito Processual. Habeas Corpus. Prisão Civil do Depositário Infiel. Pacto de São José da Costa Rica. alteração de orientação da jurisprudência do STF. concessão da ordem. 1. A matéria em julgamento neste habeas corpus envolve a temática da (in)admissibilidade da prisão civil do depositário infiel no ordenamento jurídico brasileiro no período posterior ao ingresso do Pacto de São José da Costa Rica no direito nacional. 2. Há o caráter especial do Pacto Internacional dos Direitos Civis Políticos (artigo 11) e da Convenção Americana sobre Direitos Humanos - Pacto de San José da Costa Rica (artigo 7, 7), ratificados, sem reserva, pelo Brasil, no ano de 1992. A esses diplomas internacionais sobre direitos humanos é reservado o lugar específico no ordenamento jurídico, estando abaixo da Constituição, porém acima da legislação interna. O status normativo supralegal dos tratados internacionais de direitos humanos subscritos pelo Brasil, torna inaplicável a legislação infraconstitucional com ele conflitante, seja ela anterior ou posterior ao ato de ratificação. 3. Na atualidade a única hipótese de prisão civil, no Direito brasileiro, é a do devedor de alimentos. $O$ artigo $5^{\circ}, \S 2^{\circ}$, da Carta Magna, expressamente estabeleceu que os direitos e garantias expressos no caput do mesmo dispositivo não excluem outros decorrentes do regime dos princípios por ela adotados, ou dos tratados internacionais em que a República Federativa do Brasil seja parte. O Pacto de São José da Costa Rica, entendido como um tratado internacional em matéria de direitos humanos, expressamente, só admite, no seu bojo, a possibilidade de prisão civil do devedor de alimentos e, conseqüentemente, não admite mais a possibilidade de prisão civil do depositário infiel. 4. Habeas corpus concedido. HC 94702/GO Goiás. Relatora: Min. Ellen Gracie. Julgamento: 07/10/2008. Órgão Julgador: Segunda Turma. Supremo Tribunal Federal."
} 
É nesse contexto, de estar sujeito à jurisdição compulsória da Corte Interamericana, que o Brasil poderia sofrer uma acusação de violação de um direito ou liberdade protegida nos moldes do Pacto de São José (artigos 2, 6, 14 e 50), no caso, contra o artigo 36 da Convenção de Viena sobre Relações Consulares, por ser membro da Organização dos Estados Americanos, por ser Estado membro da Convenção Americana de Direitos Humanos haja vista sua relação com o Pacto Internacional de Direitos Civis e Políticos da ONU, possuindo a Convenção de Viena disposições concernentes ã proteção dos direitos humanos nos Estados membros da OEA.

Do estudo realizado neste capítulo conclui-se que no caso de estrangeiros detidos no Brasil, sem que as autoridades competentes brasileiras tenham garantido-lhes, efetivamente e oportunamente, o direito deles de informação e acesso ao Consulado de sua nacionalidade pode ser levado à Comissão Interamericana de Direitos Humanos, que pode acionar a Corte Interamericana. $\mathrm{O}$ Brasil pode vir ser responsabilizado pela Corte Interamericana de Direitos Humanos no caso de se demosntrar perante a Corte Interamericana de Direitos Humanos violações ao artigo 36 da Convenção de Viena de 1963, nos moldes da Opinião Consultiva n. ${ }^{\circ} 16$ de 01 de outubro de 1999, em âmbito contencioso. 
PARTe III

EFEITOS Da CASUística INTERNACIONAL RELATIVA A VIOLAÇõeS DA Convenção de Viena sobre Relações Consulares de 1963 No DIREITO BRASILEIRO 


\section{Capítulo 8}

\section{REFLEXões SOBRE A RELAÇÃO ENTRE DIREITO INTERNACIONAL PÚBLICO E DIREITO INTERNO - EFEITOS DAS SENTENÇAS E PARECERES JURÍDICOS INTERNACIONAIS NO DIREITO BRASILEIRO}

A partir do estudo da casuística internacional, percebeu-se que tanto a Corte Internacional de Justiça quanto a Corte Interamericana de Direitos Humanos valeram-se da oportunidade histórica de interpretar e regulamentar o direito de informação sobre assistência consular para preso estrangeiro, cada Corte no âmbito de sua finalidade e competência. Ambas contribuiram para o aprimoramento e avanço desse direito. A Corte da ONU, em suas decisões, e a Corte Interamericana de Direitos Humanos, em sua Opinião Consultiva n. ${ }^{\circ}$ 16/1999 orientam e esclarecem a forma como deve ser aplicado e respeitado pelo Estado Receptor, tanto perante o Estado que envia, quanto perante o indivíduo lá privado de liberdade, sob pena de sofrer uma responsabilização internacional.

Basicamente, pelo estudo da casuística internacional sobre a violação do artigo 36 da Convenção, realizada na Parte II, a Corte Internacional de Justiça reconheceu, no julgamento dos casos LAGRAND e AvENA, que nesse dispositivo existe a "interdependência entre direitos do Estado e direitos individuais dos estrangeiros privados de liberdade”. Já para a Corte Interamericana de Direitos Humanos, a cuja jurisdição obrigatória o Brasil se submete, os direitos previstos no artigo 36 da Convenção compõem o corpus iuris dos direitos humanos, no que diz respeito às garantias do devido processo legal. ${ }^{298}$

\footnotetext{
${ }^{298}$ ARAúJO, Nadia de. A influência das opiniões consultivas da Corte Interamericana de Direitos Humanos no ordenamento jurídico brasileiro... p. 229.
} 
Nesta etapa do estudo, a problemática consiste em procurar identificar quais seriam os efeitos dessa casuística no Direito brasileiro, uma vez que o Brasil não foi parte nos casos apreciados pela Corte Internacional de Justiça, tampouco reconhece sua jurisdição compulsória. Por outro lado, embora não tenha tido participação no procedimento correspondente à Opinião Consultiva n. ${ }^{0} 16$ da Corte Interamericana de Direitos Humanos, o Brasil submete-se à Comissão Interamericana e, a partir 10 de dezembro de 1998, à Corte Interamericana, data de depósito do intrumento de reconhecimento a nível internacional, havendo promulgado-a internamente pelo Decreto Legislativo n. ${ }^{\circ} 89$, de 03 de dezembro de 1998. ${ }^{299}$

A proposta aqui permite abordar duas vertentes. A primeira é primordialmente internacional, no sentido de verificar qual seria a conseqüência para o Brasil em caso de cometer violação ao artigo 36 da Convenção. Questiona-se ao longo do texto se as sentenças da Corte Internacional de Justiça surtiriam efeitos com relação a terceiros Estados que fazem parte do tratado, como o Brasil, e se interpretações diversas ao entendimento do tribunal judicial das Nações Unidas poderiam ser dadas nos tribunais internos. Sugere-se que o efeito das decisões da Corte Internacional de Justiça no Direito brasileiro seria semelhante ao das Opiniões Consultivas da Corte Interamericana de Direitos Humanos, no sentido esclarecedor sobre a aplicação do tratado em âmbito interno.

E ainda nesse âmbito internacional, o estudo suscita a discussão sobre se poderia o Brasil reclamar internacionalmente pela violação do direito de assistência consular para seus súditos presos nos Estados americanos que igualmente reconhecem a jurisdição da Corte. Muito embora não seja esse o propósito principal desta dissertação de Mestrado, já que essa abordagem exigiria pesquisa própria, com

299 O Decreto Legislativo n. ${ }^{\circ}$ 89, de 03 de dezembro de 1998, foi expedido em atendimento à Mensagem n. ${ }^{\circ}$ 1.070, de 1998, enviada pelo Senhor Presidente da República ao Congresso Nacional. De acordo com o artigo 62. 1 do Pacto San Jose, "Todo Estado-parte pode, no momento do depósito do seu instrumento de ratificação desta Convenção ou de adesão a ela, ou em qualquer momento posterior, declarar que reconhece como obrigatória, de pleno direito e sem convenção especial, a competência da Corte em todos os casos relativos à interpretação ou aplicação desta Convenção". 
os instrumentos metodológicos específicos, e envolveria contribuição suficientemente original a respeito do tema, a ser pesquisado em tese de Doutorado.

O viés "interno" do estudo dos casos é o objeto principal do trabalho, e será tratado de aqui em diante, consistindo no exame da hipótese de se aplicar internamente a interpretação dada pelos dois tribunais internacionais na apreciação do direito de informação sobre asssitência consular para preso estrangeiro, e enquadrando-se esse direito no pacote dos componentes que formam as garantias o devido processo legal conforme o Direito brasileiro, notadamente na efetivação do direito à ampla defesa.

Muito embora seja um tratado inter-Estatal, a problemática encontra abrigo no $\S 2^{\circ}$ do artigo $5^{\circ}$ da Constituição Federal de 1988 , que dispõe que " $O s$ direitos e garantias expressos nesta Constituição não excluem outros decorrentes do regime e dos princípios por ela adotados, ou dos tratados internacionais em que a República Federativa do Brasil seja parte". O desafio é argumentar se a não efetivação do direito de informação a preso estrangeiro sobre o direito de assistência consular, por autoridade brasileira competente, poderia acarretar em eventual nulidade processual penal.

Antes de tudo, considerando que o tema desta pesquisa representa uma articulação entre o Direito Internacional Público e o Direito Processual Penal é conveniente ilustrar, ainda que sem a necessidade de insistir em teorias clássicas de Direito Internacional Público, a relação existente entre ambos. Em seguida, ainda que já esteja consagrado o status dos tratados internacionais no Direito brasileiro, conforme entendimento jurisprudencial do Supremo Tribunal Federal e pelo $\S 3^{\circ}$ do artigo $5^{\circ}$ da Constituição Federal, retoma-se essa eterna discussão, com o intuito de instigar a reflexão quanto ao status dos direitos previstos pelo artigo 36 da Convenção no Direito brasileiro. Adiante, partiremos para a identificação da incorporação das regras do artigo 36 da Convenção de Viena sobre Relações Consulares de 1963, a partir da análise da Constituição Federal de 1988 e da legislação processual penal vigente. 
Apesar de ter se vinculado à Convenção Americana de Direitos Humanos em setembro de 1992, por força do Decreto $n .{ }^{\circ} 678$, de 06 de novembro de 1992, o Brasil aceitou internamente a cláusula facultativa de reconhecimento da jurisdição compulsória da Corte Interamericana de Direitos Humanos por força do Decreto Legislativo n. 89, de 03 de dezembro de 1998, havendo promulgado a Declaração de Reconhecimento da Competência Obrigatória da Corte Interamericana de Direitos Humanos, sob reserva de reciprocidade, por força do Decreto n. ${ }^{\circ} 4.463$, de 8 de novembro de 2002 .

Mas com relação às Opiniões Consultivas, cuja função é interpretar normas jurídicas internacionais, fixando o seu alcance e conteúdo, mesmo na ausência de casos contenciosos, possibilitando uma maior certeza jurídica aos sujeitos de Direito Internacional $^{300}$, o Brasil obriga-se ao entendimento das Opiniões Consulativas emitidas pela Corte Interamericana desde a ratificação da Convenção Americana, em 25 de setembro de $1992 .^{301}$ Assim que, a partir do entendimento da Corte Intermericana de Direitos Humanos quanto ao direito de informação sobre assistência consular para preso estrangeiro, o Brasil bem que pode vir a ser responsabilizado internacionalmente pela Corte Interamericana de Direitos Humanos, no caso de violações contra o direito de informação sobre a assistência consular para presos estrangeiros.

A Corte Internacional de Justiça é o principal órgão judicial das Nações Unidas, segundo o artigo 92 da Carta das Nações Unidas, da qual faz parte integrante o Estatuto da Corte Internacional de Justiça, assinada em São Francisco, a 26 de junho de 1945, por ocasião da Conferência de Organização Internacional das Nações Unidas. O Brasil promulgou a Carta das Nações Unidas por força do Decreto n. ${ }^{\circ} 19.841$, de 22 de outubro de 1945.

\footnotetext{
${ }^{300}$ RAMOS, André de Carvalho. Direitos Humanos em Juízo, pp. 341-342.

${ }^{301}$ BRAWERMAN, André e outros. Jurisprudência da Corte Interamericana de Direitos Humanos. 2.1 Jurisdição Consultiva. 2.1.1 Nota Introdutória à Jurisdição Consultiva da Corte Interamericana de Direitos Humanos. Disponível online em: http://www.pge.sp.gov.br/centrodeestudos/bibliotecavirtual/interamericano/211 nota.htm> (acesso em 24/06/2009).
} 
O Estatuto da Corte Internacional de Justiça, estabelece o enquadramento organizacional e os procedimentos que regem os casos julgados pela Corte. Nos termos do artigo 94 da Carta, "cada Membro das Nações Unidas se compromete a conformar-se com a decisão da Corte Internacional de Justiça em qualquer caso em que for parte". Os artigos 59, 61 e 63(2) do Estatuto referem-se aos efeitos jurídicos das decisões da Corte, enquanto o artigo 41(1) às Medidas Provisórias ${ }^{302}$; essas regras são complementadas por outras previstas no Regulamento da Corte, adotado em 1978 ${ }^{303}$. Porém, a submissão à jurisdição da Corte Internacional de Justiça, "em qualquer caso", depende do consentimento das partes.

O artigo 36 do Estatuto da Corte delineia as duas maneiras pelas quais um Estado pode aceitar a sua jurisdição: 1) o consentimento pode ser geral, isto é, a jurisdição para solução de qualquer questão sobre interpretação e aplicação de um tratado ou do Direito Internacional Geral, cuja declaração deve ser remetida ao depósito ao Secretário Geral das Nações Unidas, para transmissão aos outros membros da comunidade internacional; ou 2) o Estado pode aceitar especificamente a competência de uma categoria especial de casos ou conflitos nos termos de um tratado em separado. ${ }^{304}$

\footnotetext{
${ }^{302}$ Estatuto da Corte Internacional de Justiça: Artigo 59: A decisão da Corte não é obrigatória senão para as partes em litígio e respeito ao caso alvo de decisão.

Artigo 61. 1. A revisão de uma sentença somente poderá ser pedida, quando a solicitação se fundamente na descoberta de um fato de tal natureza que possa ser fator decisivo e que, quando a sentença for pronunciada, fora do conhecimento da Corte e da parte que peça a sua revisão, sempre que seu desconhecimento não seja por negligência. 2. A Corte abrirá o processo de revisão segundo uma resolução em que se faça constar expressamente a existência de um fato novo, em que se reconheça que este fato por sua natureza justifica a revisão, e em que se declare que tenha lugar a solicitação. 3. Antes de iniciar o processo de revisão a Corte poderá exigir que seja cumprido o disposto pela sentença.

4. A solicitação de revisão deverá ser formulada dentro do prazo de seis meses depois de descoberto o fato novo. 5. Não poderá ser pedida a revisão uma vez transcorrido o prazo de dez anos a partir do pronunciamento da sentença.

Artigo 63. 1. Quando se trate da interpretação de uma convenção na qual tomem parte outros Estados além das partes em litígio, o Secretário notificará imediatamente a todos os Estados interessados. 2. Todo estado assim notificado terá direito a intervir no processo; mas se exerce desse direito, a interpretação contida na sentença será igualmente obrigatória para ele.

${ }^{303}$ Internacional Court of Justice. Rules of the Court. Article 94. 1. When the Court has completed its deliberations and adopted its judgment, the parties shall be notified of the date on which it will be read. 2. The judgment shall be read at a public sitting of the Court and shall become binding on the parties on the day of the reading.

${ }_{304}$ Originalmente, os EUA consentiram com a jurisdição geral da Corte Internacional de Justiça em 1946, mas denunciaram-na em 1985. U. S. Dept. of State Letter and Statement Concerning Termination of Acceptance of ICJ Compulsory Jurisdiction (Oct. 7, 1985).
} 
Por outro lado, o que limita a sua atuação é a competência exclusiva para julgar questões envolvendo apenas Estados, conforme o artigo 34.1 de seu Estatuto, cujas decisões exercem força vinculante apenas entre os Estados que, na condição de partes, aceitaram a jurisdição da Corte Internacional de Justiça, e com relação apenas à controvérsia em questão. É exatamente nesse contexto indagação: conforme o artigo 59 do Estatuto, suas decisões não são obrigatórias, senão para as partes em litígio, e respeito ao caso alvo. Daí, muito embora as decisões dos casos objeto deste estudo vinculem apenas as partes dos litígios e das sentenças ${ }^{305}$, seus preceitos sobre o avanço da prática do direito de assistência consular para preso estrangeiro trazem importantes lições e orientações que se estenderiam obrigatoriamente para todos os Estados-partes da Convenção de Viena sobre Relações Consulares, independentemente de terem participado ou não dos casos.

O Brasil ainda não reconhece a jurisdição compulsória geral da Corte judicial das Nações Unidas, talvez por uma questão de pura inércia, e tampouco aderiu ao Protocolo Facultativo à Convenção de Viena sobre Relações Consulares de 1963 sobre Solução Compulsória de Controvérsias. ${ }^{306}$ Muito menos ainda participou dos casos contenciosos objeto da presente pesquisa. Mas não é por não estar juridicamente vinculado às decisões dos casos LAGRAND e AvEnA que o Brasil poderia justificar a aplicação, em seus tribunais internos, de entendimento diverso do definido pela Corte judicial das Nações Unidas.

A Corte Internacional de Justiça é o grande intérprete do Direito Internacional Geral e o único tribunal internacional de jurisdição geral. Esse é justamente o papel reservado à Corte Internacional de Justiça, que pode levar em

\footnotetext{
305 Artigo 59 do Estatuto da CIJ: “A decisão da Corte não é obrigatória senão para as partes em litígio e respeito ao caso alvo de decisão". Opinião Consultiva OC N. 16/99, de $1^{\circ}$ de outubro de 1999, solicitada pelos Estados Unidos Mexicanos perante a Corte Interamericana de Direitos Humanos. $O$ direito à informação sobre a assistência consular no âmbito das garantias do devido processo legal, par. 117.

306 “(...) Expressing their wish to resort in all matters concerning them in respect of any dispute arising out of the interpretation or application of the Convention to the compulsory jurisdiction of the International Court of Justice, unless some other form of settlement has been agreed upon by the parties within a reasonable period, Have agreed as follows : Article I. Disputes arising out of the interpretation or application of the Convention shall lie within the compulsory jurisdiction of the International Court of Justice and may accordingly be brought before the Court by an application made by any party to the dispute being a Party to the present Protocol." Optional Protocol concerning the Compulsory Settlement of Disputes. United Nations Conference on Consular Relations Vienna, Austria, 4 March - 22 April 1963. Document: A/CONF.25/15.
} 
conta a evolução do Direito Internacional em todo o espectro das relações internacionais. Seus julgamentos, ordens de medidas provisórias e pareceres consultivos, como resultado, refletem a perspectiva de um tribunal sem restrições por limitações estreitas que um regime especial pode impor. Seus pronunciamentos sobre Direito Internacional Geral são necessariamente mais persuasivos do que declarações semelhantes feitas por tribunais com competência e perspectivas mais limitadas, em decisões bem fundamentadas e de altíssimo nível. Ainda é o protagonista entre os tribunais internacionais, e continuará a influenciar as decisões dos tribunais internacionais especializados existentes hoje. A Corte Internacional de Justiça ultrapassa sua competência nominal - sem dúvidas que desempenha papel fundamental na manutenção da coerência da interpretação do Direito Internacional Geral - uma função valiosa. ${ }^{307}$

O Direito Internacional Público não pode mais ser visto como um "terreno estranho" aos olhos do Direito Processual brasileiro. O tratado regularmente incorporado ao direito positivo interno brasileiro pode e deve ser aplicado e reconhecido perante os tribunais internos, sobretudo quando se trata de direito individual que a Corte Interamericana de Direitos Humanos confirmou que compõe o pacote das garantias que formam o devido processo legal, como é o caso dos direitos de réus estrangeiros. In casu, O tratado protagonista é a Convenção de Viena sobre Relações Consulares de 1963, incorporada ao ordenamento positivo interno brasileiro por força do Decreto ${ }^{\circ} 61.078$ de 26 de julho de 1967, que promulgou e lhe conferiu executoriedade e vigência no plano doméstico; portanto, é fonte soberana de direito público, de plena e irrestrita vigência interna.

\footnotetext{
307 ChaRneY, Jonathan I. The impact on the international legal system of the growth of international courts and tribunals. Materials and Publications. NYU Journal of International Law and Politics, Vol. 31, p. 705. Disponível online em: <http://www.pictpcti.org/publications/PICT_articles/JILP/Charney.pdf> (acesso em 29/09/2010).

307 CHARNEY, Jonathan I. The impact on the international legal system of the growth of international courts and tribunals. Materials and Publications. NYU Journal of International Law and Politics, Vol. 31, p. 702. Disponível online em: <http://www.pictpcti.org/publications/PICT_articles/JILP/Charney.pdf> (acesso em 29/09/2010).
} 


\subsection{A incorporação dos tratados internacionais ao ordenamento positivo interno brasileiro - o status da Convenção de Viena sobre Relações Consulares de 1963}

Os tratados ainda são considerados como sendo a fonte mais importante do Direito Internacional - é uma fonte democrática, haja vista a participação direta dos Estados. ${ }^{308}$ No tocante ao uso da terminologia, as Convenções de Viena sobre Direito dos Tratados de 1969, a qual o Brasil é parte ${ }^{309}$, e a de 1986 e a Convenção de Viena sobre o Direito dos Tratados entre Estados e Organizações Internacionais ou entre Organizações Internacionais, que ainda não entrou em vigor porque não atinigu o número suficiente de signatários ${ }^{310}$, todo acordo regido pelo Direito Internacional é tratado, qualquer que seja a sua denominação, ou seja, convenção, protocolo, convênio, declaração. Assim, tratado é a expressão genérica do acordo de vontades entre Estados e Organizações Internacionais, estipulando direitos e obrigações entre esses. ${ }^{311}$

Conforme dispõe o artigo $2^{\circ}, a$, da Convenção de Viena sobre Direito dos Tratados de 1969, finalmente promulgada no Brasil por força do Decreto 7030, de 14 de dezembro de 2009, "tratado significa um acordo internacional concluído por escrito entre Estados e regido pelo Direito Internacional, quer conste de um instrumento único, quer de dois ou mais instrumentos conexos, qualquer que seja sua denominação específica. PEDRO DALLARI conceitua tratado como um "diploma jurídico que estrutura e expressa uma norma de conduta convencionada internacionalmente, a partir da vontade manifesta de Estados ou organizações internacionais". Deve produzir efeitos de direito, na sua dupla qualidade de ato jurídico e de norma. ${ }^{312}$

\footnotetext{
${ }^{308}$ Mello, Celso D. de Albuquerque. Curso de Direito Internacional Público, p. 212.

${ }^{309}$ Por meio do Decreto $n^{\circ} 7.030$, de 14 de dezembro de 2009 o Brasil promulgou a Convenção de Viena sobre o Direito dos Tratados, concluída em 23 de maio de 1969, com reserva aos Artigos 25 e 66, havendo o Governo brasileiro depositado o instrumento de ratificação da referida Convenção junto ao Secretário-Geral das Nações Unidas em 25 de setembro de 2009.

${ }^{310}$ O Brasil assinou a Convenção em 21.3.1986, mas ainda não foi aprovado no Congresso Nacional e, por isso, não apresentou o instrumento de ratificação junto ao Secretário-Geral da ONU. Disponível online em: < http://treaties.un.org/Pages/ViewDetails.aspx?src=TREATY\&mtdsg_no=XXIII$3 \&$ chapter=23\&lang=en $>$ (acesso em março de 2011).

${ }^{311}$ ACCIOLY, Hildebrando, Silva, G.E. do Nascimento e, CASELLA, Paulo Borba. Manual de Direito Internacional Público, $16^{\mathrm{a}}$ Ed., p. 132.

${ }^{312}$ DALlaRI, Pedro B. A. Constituição e Tratados Internacionais, pp. 17-18.
} 
O sistema jurídico internacional é entendido como necessário para a realização da convivência ordenada - um sistema de ordenação das relações entre sujeitos de Direito Internacional, regulado por normas desde que se tenha e se preserve patamar mínimo de consistência dos princípios, na interpretação das regras e na aplicação dos procedimentos desse sistema, como em qualquer sistema normativo, de como os Estados devem se comportar. O Direito Internacional contemporâneo exprime a convicção quando à juridicidade e a necessidade, não sendo mais de coexistência entre os Estados, como era configurado desde a criação da LigA DAS NAÇÕES, em 1919, que desenhou o sistema internacional contemporâneo. A partir da criação da ORGANIZAÇÃO DAS NAÇÕES UNIDAS em 1945, passa a ser considerado um sistema de coordenação, com vistas à integração. $\mathrm{O}$ reconhecimento de novos sujeitos de Direito Internacional, como as organizações internacionais, e o surgimento de novos tribunais internacionais para atendere a especialização do Direito Internacional contemporâneo caracterizam o tempo histórico e o contexto cultural atual que PAUlo Borba CASElla denomina "pósmoderno" 313

ANTONIO CASSESE ${ }^{314}$ observa que, normalmente, no direito interno dos Estados existe uma hierarquia entre as fontes de Direito e entre as regras que produzem essas fontes. E essa estrutura normativa hierárquica reflete a vontade do povo, abrangida na Constituição, de fazer de determinados comandos "mais importantes ou "mais fortes", com valores compartilhados pela esmagadora maioria da população. Por outro lado, no Direito Internacional clássico não existe hierarquia entre suas fontes, ao menos entre as principais, tratados e costumes internacional, porque ambos compartilham igual status. A razão disso era a de que os Estados não pretendiam impor limitações aos seus poderes soberanos aos quais não tivessem aceitado expressa ou implicitamente. Até mesmo se o processo criador do costume fosse de natureza geral e resultasse em regras vinculantes para toda a comunidade internacional, essas não podiam sobrepor-se aos termos de um tratado anteriormente celebrado entre dois ou mais Estados.

\footnotetext{
${ }^{313}$ A Liga das Nações pode até não ter evitado a II Guerra Mundial, mas sem dúvidas que representou a instauração de patamar nunca antes representado e mutação qualitativa do Direito Internacional, de reconhecimento de um novo sujeito de direito internacional. CASELLA, Paulo Borba. Fundamentos do Direito Internacional Pós-Moderno, pp. 17-24.

${ }^{314}$ CASSESE, Antonio. Internacional Law, p. 198 e ss.
} 
A sociedade internacional contemporânea é, portanto, descentralizada e horizontal. Cada um de seus integrantes dita, no que lhe concerne, as regras de composição entre o Direito Internacional e a sua implementação interna. JONATHAN CHARNEY $^{315}$ apontou que o Direito Internacional é um sistema jurídico que carece de instituições clássicas de Executivo e Legislativas para criação do Direito. Igualmente, carece de um sistema judicial com jurisdição obrigatória para todos os Estados, para a interpretação e aplicação do Direito, e exerce essas funções por meio de processos e instituições descentralizadas. É criado pelos Estados, com o apoio de outros sujeitos, as organizações internacionais, até mesmo de pessoas naturais e organismos não-governamentais, independentemente de serem esses, ou não, sujeitos de Direito Internacional Público.

Nesse mesmo sentido, PaUlo Borba CASElla ${ }^{316}$ observa que o ordenamento jurídico internacional tem suas características específicas. O ponto de partida do Direito Internacional está no princípio de soberania, que serve ao menos para esclarecer a natureza específica do ordenamento internacional, que é integrado por Estados independentes iguais e soberanos e, hoje, organizações internacionais, agentes não-estatais, e com papel destacado para o indivíduo. Daí a impossibilidade de se instaurar autoridade central dotada de poder coercitivo, capaz de garantir a observância das normas, verificando-se uma verdadeira "dispersão do poder", ficando difícil definir critério objetivo de identificação da legalidade. Desta forma, CASElla caracteriza o ordenamento jurídico internacional de "agregação de mecanismos de convivência entre soberanias iguais".

Uma das conseqüências prática desta “dispersão do poder" é a relativa perda da autonomia do Direito Internacional, na medida em que acaba por ter que delegar as modalidades práticas de sua aplicação aos órgãos internos dos Estados, um verdadeiro "desdobramento funcional". O papel principal do Direito Internacional é regular a convivência ordenada da sociedade internacional, com fundamentos em valores ou princípios aceitos e aplicados, para a interação dos sujeitos de Direito Internacional, por excelência os Estados e, em grau crescente, as organizações

\footnotetext{
${ }^{315}$ CHARNEY, Jonathan I. Is international law threatened by multiple international tribunals?, p. 115.

${ }^{316}$ CASELLA, Paulo Borba. Fundamentos do Direito Internacional Pós-Moderno, p. 665 e ss.
} 
internacionais, com gradual reconhecimento do ser humano. Não é mais possível negar o reconhecimento da condição do ser humano como sujeito de Direito Internacional Público, mesmo que essa condição seja, na prática, restrita aos limites atribuídos pelos Estados. O Direito e o Estado se justificam pelo seu fim último: o ser humano, e não o inverso. ${ }^{317}$

Com a extensão do papel do Direito Internacional "pós-moderno", resultado da multiplicação de seus foros, especialidades, sujeitos e agentes, questões começam a surgir em paralelo ao papel a ser desempenhado pelo Estado no sistema internacional, quanto à relação entre a ordem jurídica interna de um Estado em particular e as regras e princípios que regem a comunidade internacional como um todo. O Direito nacional rege os aspectos internos do governo e trata de questões entre os indivíduos, e entre os indivíduos e seu aparelho administrativo. O Direito Internacional se concentra primordialmente sobre as relações entre os Estados. Mas isso parece ser um raciocínio simplista - há casos em que a mesma situação vem sendo analisada tanto por instâncias nacionais como por tribunais internacionais, que podem inter-relacionar suas decisões, em um processo complexo de interação, como nos casos da Corte Internacional de Justiça, estudados anteriormente, em que a Corte mostra-se que é competente para avaliar a medida com as obrigações assumidas pelas partes da Convenção de Viena sobre Relações Consulares comprometem seus tribunais internos em relação aos nacionais de outro Estado, para verificar se houve violação ao tratado internacional. ${ }^{318}$ Daí outro "viés interno" do Direito Internacional Público contemporâneo.

\footnotetext{
${ }^{317}$ CASElla, Paulo Borba. Fundamentos do Direito Internacional Pós-Moderno, pp. 665-669.

${ }^{318}$ SHAw, Malcon. International Law, pp. 129-130. O autor dá como exemplo os casos em questão em que os Estados Unidos violaram suas obrigações internacionais ao não permitirem o acesso de estrangeiros presos à assistência consular, conforme disposto pelo artigo 36 da Convenção de Viena sobre Relações Consulares, tendo sido objeto de jurisprudência tanto na Corte Internacional de Justiça, da Corte Interamericana de Direitos Humanos, e dos tribunais internos norte americanos. Destacamos um trecho da sentença do caso Avena, da Corte Internacional de Justiça, que refere esse sentido: "If and so far as the Court may find that the obligations accepted by the parties to the Vienna Convention included commitments as to the conduct of their municipal courts in relation to the nationals of other parties, then in order to ascertain whether there have been breaches of the Convention, the Court must be able to examine the actions of those courts in the light of international law. The Court is unable to uphold the contention of the United States that, as a matter of jurisdiction, it is debarred from enquiring into the conduct of criminal proceedings in United States courts. How far it may do so in the present case is a matter for the merits." Outra passagem é a seguinte: "The Court would first observe that the individual rights of Mexican nationals under subparagraph 1 (b) of Article 36 of the Vienna Convention are rights which are to be asserted, at any rate in the first place, within the domestic legal system of the United States." Case concerning Avena and other Mexican
} 
Conforme ensina LOUIS HENKIN ${ }^{319}$, todos os Estados da comunidade internacional sujeitam-se ao Direito Internacional, mas cada Estado governa seus assuntos internos por meio de seu próprio sistema jurídico interno. Essa "dicotomia" está implícita no sistema estatal - o Direito Internacional, que rege relações entre Estados autônomos, separados, independentes, impermeáveis, não tem qualquer preocupação óbvia, ou interesse, no direito interno do Estado, além da exigência de que o Estado cumpra suas obrigações internacionais assumidas. Não impõe um modo particular de cumprimento, ou por intermédio de determinadas instituições particulares ou leis. O descumprimento de uma obrigação internacional resulta na responsabilização do Estado. ${ }^{320}$

PEDRo DALlari sustenta a conveniência de adoção de um sistema articulado e coerente de recepção de tratados no direito brasileiro, ou seja, um "Monismo de Compatibilização", que implica na integração das normas de Direito Internacional Público com o direito interno do Estado, que se condicionam e se influenciam mutuamente. Substitui o enfoque em torno da primazia de uma ordem sobre a outra pela articulação entre ambas, superando-se inclusive a polarização entre

nationals (Mexico $v$. United States of America), ICJ Reports of Judgments, advisory opinions and orders (27/06/2004), parág. 40.

319 HENKIN, Louis. International Law: politics, values and functions, pp. 88- 89. O Professor ressalta que, geralmente a relação entre o direito interno do Estado e como este lida com suas obrigações de direito internacional está disposta em sua Constituição. As disposições em matéria de direito internacional em qualquer Constituição refletiram as forças políticas internas do Estado, em vez de forças inter-estatais no sistema internacional. No entanto, cada vez mais o direito interno dos Estados e sua relação com o direito internacional tornaram-se importantes para os advogados internacionais, bem como para os atores políticos e observadores. Na verdade, cada vez mais os Estados têm encontrado desejável, se não indispensável, incorporar as suas obrigações internacionais em sua legislação interna. Cada vez mais, tratados internacionais - especialmente os de direitos humanos - criaram obrigações expressas em que os Estados-partes devem modificar a sua legislação interna. Em especial, em contextos políticos como das Comunidades Européias, os Estados concordaram em fundir suas leis domésticas e internacionais, de modo a criar nova relação entre os dois sistemas de direito.

${ }^{320}$ HENKIN, Louis. International Law: politics, values and functions, p. 89. Ele defende que as Constituições Estatais reconheçam a supremacia do Direito Internacional. Aqueles que adotam a abordagem Monista tendem a cair em duas categorias distintas: aqueles que, como o inglês LAUTERPACHT, mantêm uma forte posição ética naturalista com uma profunda preocupação pelos direitos humanos; e outros, como KelSEN, que mantêm uma posição Monista com base em fundamentos lógicos e formalistas. A visão naturalista de LAUTERPACHT enxerga como função primária de todo Direito como preocupado com o bem-estar dos indivíduos, e defende a supremacia do Direito Internacional como o melhor método disponível para alcançar isso. É uma abordagem com profunda desconfiança de um sistema internacional baseado na soberania e na independência absoluta dos Estados, pela esperança na capacidade das regras do Direito Internacional para imbuir a ordem internacional com senso de propósito moral e de justiça, fundada sobre o respeito pelos direitos humanos e o bem-estar dos indivíduos. SHAW, Malcon. International Law, p. 132. 
Monismo Nacionalista e Internacionalista. ${ }^{321}$ No sistema brasileiro, o Monismo encontra as vertentes: radical, que prega a primazia do tratado sobre a ordem jurídica interna; e a moderada, que equipara o tratado à lei ordinária, subordinando-o à Constituição e à aplicação do critério cronológico, em caso de conflitar com norma superveniente. $^{322}$

Apesar das teorias Monista e Dualista, o fato é que para a maior parte das regras de Direito Internacional tornarem operativas (com exceção ao Jus Cogens - as normas imperativas ${ }^{323}$ ), precisam ser aplicadas pelo Estado no âmbito do seu ordenamento jurídico interno. Não existe uma regulamentação internacional que garanta a aplicação interna uniforme de suas regras. O Direito Internacional apenas determina que os Estados não podem invocar procedimentos jurídicos de seu sistema interno como justificativa para não cumprirem com suas obrigações internacionais. ${ }^{324}$ E isso está sacramentado como norma costumeira de direito internacional, positivada pelo artigo 27 da Convenção de Viena sobre Direito dos Tratados de 1969, que

${ }^{321}$ DALlaRI, Pedro B. A. Constituição e Tratados Internacionais, p. 13.

322 O professor PaUlo Borba CASElla observa que se identificam momentos diferentes concernentemente a discussão entre fontes de origem internacional (tratados) e fontes de origem interna (leis). O primeiro momento tem a ver com a incorporação das fontes internacionais ao ordenamento jurídico interno. $\mathrm{O}$ segundo tem a ver com a posição hierárquica nesse ordenamento, sempre após a efetivação da incorporação - é por essa imperiosidade que o Brasil adotaria, de certa forma, uma posição Dualista moderada, porque somente depois de incorporadas ao ordenamento jurídico interno, podem as normas de origem internacional criar direitos e deveres para os particulares, ainda que anteriormente a isso tenha o Estado assumido, em relação a seus co-contratantes, suas obrigações no plano internacional por ratificação e depósito desse instrumento. ACCIOLY, Hildebrando, Silva, G.E. do Nascimento e, CASElla, Paulo Borba. Manual de Direito Internacional Público, $16^{\text {a }}$ Ed., pp. 212-213.

323 Convenção de Viena sobre Relações Consulares de 1969 (Decreto 7030 de 14 de dezembro de 2009): Artigo 53. Tratado em Conflito com uma Norma Imperativa de Direito. Internacional Geral (jus cogens). É nulo um tratado que, no momento de sua conclusão, conflite com uma norma imperativa de Direito Internacional geral. Para os fins da presente Convenção, uma norma imperativa de Direito Internacional geral é uma norma aceita e reconhecida pela comunidade internacional dos Estados como um todo, como norma da qual nenhuma derrogação é permitida e que só pode ser modificada por norma ulterior de Direito Internacional geral da mesma natureza.

${ }^{324}$ No caso "Applicability of the Obligation to Arbitrate under Section 21 of the United Nations Headquarters Agreement of 26 June 1947", A Corte Internacional de Justiça estabeleceu que : "It would be sufficient to recall the fundamental principle of international law that international law prevails over domestic law. This principle was endorsed by judicial decision as long ago as the arbitral award of 14 September 1872 in the Alabama case between Great Britain and the United States, and has frequently been recalled since, for example in the case concerning the GrecoBulgarian "Communities" in which the Permanent Court of International Justice laid it down that "it is a generally accepted principle of international law that in the relations between Powers who are contracting Parties to a treaty, the provisions of municipal law cannot prevail over those of the treaty" (P.C.I.J., Series B, No. 17, p. 32). ICJ. Reports of judgments, advisory opinions and orders. Applicability of the obligation to arbitrate under section 21 of the United Nations headquarters agreement OF 26 JUNE 1947 Advisory Opinion of 26 April 1988. Parág. 57, pp. 2627. 
finalmente foi promulgada no Brasil por força do Decreto n. 7030 de 14 de dezembro de 2009. Sem falar de outros tratados que estabelecem que os Estadospartes comprometam-se a conformar sua legislação ao tratado para o fim de implementá-lo internamente, especialmente aqueles referentes aos direitos humanos. $^{325}$

Já que o Direito Internacional não possui mecanismo ou regulamentação para a implementação e execução interna de suas normas, os Estados ficam completamente livres a respeito de como cumprir, nacionalmente, suas obrigações internacionais, sendo que o descumprimento de suas obrigações internacionais causa responsabilização. ${ }^{326}$

A posição hierárquica do tratado face ao Direito brasileiro, depois de devidamente internalizado, passou a ser discutida com a decisão do Recurso Extraordinário n. ${ }^{\circ}$ 71.154, julgado pelo Supremo Tribunal Federal em 04 de agosto de $1971 .^{327}$ Foi o Supremo Tribunal Federal, com o julgamento do Recurso

325 Artigos 49.1; 50.1; 129.1; e 146.1 das Convenções de Genebra de 12 de agosto de 1949. Convenção Internacional sobre a Eliminação de todas as Formas de Discriminação Racial. Artigo 2.1 do Pacto Internacional sobre Direitos Civis e Políticos. Artigo 2.1 do Pacto Internacional sobre Direitos Econômicos, Sociais e Culturais. Artigo 2 da Convenção Americana sobre Direitos Humanos (Pacto de São José da Costa Rica).

${ }^{326}$ Os Estados consideram que a tradução dos comandos internacionais em padrões jurídicos internos como sendo resultado de sua soberania e cada Estado decide como fazer do Direito Internacional vinculante internamente, e qual status ou hierarquia conferir as normas internacionais que adere, com relação a seu ordenamento jurídico interno. CASSESE, Antonio. Internacional Law, pp. 216-220. A Corte Internacional de Justiça reforçou esse princípio no caso LAGRAND, ao salientar que a doutrina de direito interno aplicada pelos tribunais estaduais norte-americanos e pela Suprema Corte, a doctrine of procedural default, não poderia ser aplicada para impedir o cumprimento dos direitos previstos pelo artigo 36 da Convenção de Viena sobre Relações Consulares, de notificação ao Consulado alemão sobre a prisão de seus nacionais, e de informação e acesso aos irmãos LAGRAND aos funcionários consulares de seu país. No mesmo sentido, no caso AVENA, a Corte observou que os direitos garantidos ao abrigo do artigo 36 da Convenção são direitos que os Estados Unidos se comprometeram a cumprir em relação ao individuo em questão, independentemente do direito ao devido processo no âmbito do direito constitucional dos Estados Unidos. Em ambos os casos, como consequiência jurídica dessa violação, a Corte Internacional de Justiça ordenou a revisão $e$ reconsideração das condenações e sentenças, à escolha dos Estados Unidos, com vistas a verificar se em cada caso de violação cometida pelas autoridades competentes causou prejuízo aos condenados no processo da administração da justiça criminal do país.

327 "Lei Uniforme sobre o Cheque, adotada pela convenção de genebra. Aprovada essa convenção pelo Congresso Nacional, e regularmente promulgada, suas normas tem aplicação imediata, inclusive naquilo em que modificarem a legislação interna. Recurso Extraordinário conhecido e provido.” RE 71154 / PR - Paraná. Relator: Ministro Oswaldo Trigueiro. Julgado em 04/08/1971. Órgão Julgador:Tribunal Pleno. O acórdão serviu de base para a Carta Rogatória 8.279, em que o Ministro Celso de Mello explicita a adoção do dualismo moderado, cuja claridade disso CASELLA 
Extraordinário n. ${ }^{\circ} 80.004^{328}$ que, em $1^{\circ}$ de junho de 1977 , firmou de modo praticamente absoluto seu posicionamento no que diz respeito à matéria: tratados internacionais, após cumprido seu itinerário de formação e internação ao Direito brasileiro, situam-se nos mesmos planos de validade, eficácia e de autoridade em que se posicionam as leis ordinárias, em virtude de se submeterem à aprovação do Poder Legislativo, em função de sua aprovação por Decreto Legislativo do Congresso Nacional (CF, artigo 49, I). Ou seja, o tratado - cujo procedimento de formação e texto foram "consentidos" pelos representantes do povo - possui força para criar direitos e obrigações sobre os cidadãos nacionais, significando uma verdadeira lei.

O processo legislativo é tema essencialmente constitucional e nossa Carta (artigos 59 a 69) não determina o escalonamento hierárquico. O que se utiliza, em caso de conflito, tanto com as leis ordinárias como com relação aos tratados é aplicação alternativa dos critérios cronológico (lex posterior derogat priori), em caso de conflito temporal, ou o da especialidade, segundo o qual a norma mais específica prevalece sobre a mais genérica. Isso ilustra o Monismo Moderado, ao determinar-se

questiona. ACCIOLY, Hildebrando, Silva, G.E. do Nascimento e, CASElla, Paulo Borba. Manual de Direito Internacional Público, 16 ${ }^{\mathrm{a}}$ Ed., p. 213.

${ }^{328}$ Recurso Extraordinário 80004/Sergipe. Relator: Ministro Xavier de Albuquerque. Julgado em 01/06/1977. Órgão Julgador: Tribunal Pleno. "Convenção de Genebra, Lei Uniforme sobre Letras de Câmbio e Notas Promissórias - aval aposto a nota promissória não registrada no prazo legal impossibilidade de ser o avalista acionado, mesmo pelas vias ordinárias. Validade do Decreto-Lei $n^{o}$ 427, de 22.01.1969. Embora a Convenção de Genebra que previu uma lei uniforme sobre letras de câmbio e notas promissórias tenha aplicabilidade no direito interno brasileiro, não se sobrepõe ela às leis do país, disso decorrendo a constitucionalidade e consequente validade do Dec-Lei $n^{\circ}$ 427/69, que institui o registro obrigatório da nota promissória em repartição fazendária, sob pena de nulidade do título. Sendo o aval um instituto do direito cambiário, inexistente será ele se reconhecida a nulidade do título cambial a que foi aposto. recurso extraordinário conhecido e provido".

GARCIA, Mário P. P. Tributo aos Tratados. In: MENEZES, Wagner (Org.). O Direito Internacional e o Direito Brasileiro, pp. 66-72. O autor comenta que após a promulgação da Constituição de 88 o tema da hierarquia dos tratados no ordenamento jurídico interno chegou ao STF em 1997, pela ADI n. ${ }^{\circ} 1.480 / \mathrm{DF}$, contra o Decreto Presidencial n. ${ }^{\circ} 1.855 / 96$, que incorporou ao ordenamento jurídico pátrio a Convenção n. 158 da Organização Internacional do Trabalho (OIT), cujo julgamento manteve a jurisprudência que se consolidou com o julgamento, em 1977, do Recurso Extraordinário n. 80.004-SE. E na mesma linha do professor carioca, Celso Albuquerque Mello, o autor afirma que esse silêncio sobre a hierarquia dos tratados, na Constituição de 88 , representa uma grande falha do constituinte. Qual o valor de um tratado se um dos contratantes, por meio de lei interna, pode deixar de aplicá-lo? Esse Recurso Estraoridário tratou de conflito envolvendo a Lei Uniforme de Genebra sobre Letras de Câmbio e Notas Promissórias, que entrou em vigor com o Decreto n 57.663 de 1966, e uma lei interna posterior, o Decreto-lei $n^{\circ} 427 / 69$, relacionando-se o conflito à obrigatoriedade ou não de existência do aval aposto na nota promissória - exigência formal para a validade do título que não constava no texto internacional. Prevaleceu, ao final do julgamento, o Decreto-lei ${ }^{\circ} 427 / 69$, valendo-se o STF da regra lex posterior derogat priori A partir de então, passou a predominar a paridade entre lei ordinária e tratado internacional, com a utilização do critério cronológico para a resolução dos conflitos entre leis internas e tratados internacionais. 
que lei interna superveniente poderá suspender os efeitos do tratado anteriormente em vigor, exceto àqueles de matéria tributária, em face do que dispõe o artigo 98 do Código Tributário Nacional, que dispõe que: "O conteúdo e o alcance dos decretos restringem-se aos das leis em função das quais sejam expedidos, determinados com observância das regras de interpretação estabelecidas nesta Lei”. Passando a integrar a legislação interna, depois de sua incorporação, o tratado encontra-se em pé de igualdade e condições às demais leis ordinárias e, desta forma, todas as incoerências que apresentar serão analisadas da mesma forma que as surgidas referentemente a essas leis, e esse é o entendimento atual.

PEDRO DALLARI ${ }^{329}$ observa que esse entendimento jurisprudencial, de mera equiparação dos tratados às leis federais, reveste-se de ambigüidades e contradições, sendo frequentemente contestada pela doutrina. Isso porque, reconhecer a paridade hierárquica entre os tratados e leis ordinárias, significa a possibilidade de lei interna suspender os efeitos do tratado internacional. Equiparar uma norma de origem internacional a uma lei ordinária configura, nas palavras de CASElla $^{330}$, uma "aberração”, um "retrocesso", "por privar a norma de direito internacional positivo de seu sentido e alcance normativo internacionais, ao mesmo tempo que se poderia configurar o descumprimento de obrigação internacional pelo Estado brasileiro, na condição de parte contratante de obrigação de direito internacional, em relação aos demais signatários desse tratado". O Estado não pode, unilateralmente, eximir-se das obrigações impostas pelo tratado, a não ser por forma própria de revogação ou denúncia.

De qualquer maneira, é na Constituição Federal da República que se deve buscar a solução normativa para a questão da incorporação dos atos internacionais ao sistema de direito positivo interno brasileiro, que determina ser da competência privativa do Presidente da República a celebração de tratados, convenções e atos internacionais, sujeitos ao referendo do Congresso Nacional

\footnotetext{
${ }^{329}$ O professor ressalta que as Constituições brasileiras sempre foram omissas quanto ao tema da recepção de tratados internacionais pelo direito interno, sendo mais tratado no plano constitucional sob a ótica da distribuição de competências entre os três poderes, e com foco na celebração e aprovação desses atos. DALLARI, Pedro B. A. Constituição e Tratados Internacionais, pp. 45 -47. 330 AcCIOLY, Hildebrando, Silva, G.E. do Nascimento e, CASELla, Paulo Borba. Manual de Direito Internacional Público, 16ª Ed., pp. 214, 215 e 219.
} 
(artigo 84, inciso VIII). Além disso, a Constituição determina ser da competência exclusiva do Congresso Nacional resolver definitivamente sobre tratados, acordos ou atos internacionais que acarretem encargos ou compromissos gravosos ao patrimônio nacional (artigo 49, inciso I). ${ }^{331}$ Portanto, no sistema adotado pelo Brasil, a execução dos tratados internacionais e a sua incorporação à ordem jurídica interna, resulta da conjugação de duas vontades homogêneas: a do Congresso Nacional, mediante Decreto Legislativo sobre tratados, acordos ou atos internacionais (Constituição de 1988, artigo 49, I); e a do Presidente da República. Além de poder celebrar esses atos de direito internacional (Constituição de 1988, artigo 84, VIII), compete ao Chefe de Estado promulgá-los mediante Decreto, cuja edição produz três efeitos básicos: (a) a promulgação do tratado internacional; (b) a publicação oficial de seu texto; e (c) a executoriedade do ato internacional. É esse Decreto que vincula e obriga no plano do direito positivo interno, conferindo ao tratado executoriedade e vigência. ${ }^{332}$

${ }^{331}$ O envio ao Congresso Nacional faz-se mediante Exposição de Motivos ao Presidente da República. As minutas de Exposição de Motivos e de Mensagem ao Congresso são preparadas pela Divisão da Secretaria de Estado responsável pela negociação do Ato ou com competência substantiva sobre a matéria. As minutas devem ser encaminhadas por memorando da Divisão competente à Divisão de Atos Internacionais, à qual cabe juntar-lhe e cópias autênticas do texto. As minutas devem, ainda, apresentar boa técnica legislativa, nos moldes da Lei Complementar no. 95, de 26 de fevereiro de 1998. Quando se tratar de ato multilateral, é necessário que o memorando da Divisão competente seja acompanhado de versão para o português do texto oficial do Ato. À Consultoria Jurídica cabe emitir parecer sobre os Atos a serem encaminhados ao referendo congressional, para atender a instruções da Casa Civil da Presidência da República contidas no Aviso 1872, de 27/10/1999. Os instrumentos firmados são encaminhados pelo Gabinete à Casa Civil Aprovada a Exposição de Motivos e assinada a Mensagem ao Congresso pelo Presidente da República, o Ato Internacional é encaminhado para exame e aprovação, sucessivamente, pela Câmara dos Deputados e pelo Senado Federal. Antes de ser levado aos respectivos plenários, o instrumento é avaliado, em ambas as Casas, pelas Comissões de Relações Exteriores, bem como por outras comissões interessadas pela matéria. ATOS INTERNACIONAIS. PRÁtICA DIPLOMÁtICA BRASILEIRA. MANUAl DE PROCEDIMENTOS. Ministério das Relações Exteriores. Divisão de Atos Internacionais. Brasília, maio de 2008. Disponível online em: $<$ http://www2.mre.gov.br/dai/PraticaDiplomaticaBrasileira.pdf> (acesso em janeiro de 2011).

332 Atos InTERnACIONAIS. PRÁtiCA DIPLOMÁtiCA BRASILEIRA. MANUAL DE PROCEDIMENTOS. Ministério das Relações Exteriores. Divisão de Atos Internacionais. Brasilia, maio de 2008. Disponível online em: <http://www2.mre.gov.br/dai/PraticaDiplomaticaBrasileira.pdf> (acesso em janeiro de 2011). O tratado é ratificado por meio do depósito da Carta de Ratificação junto ao país ou órgão multilateral depositário, que se incumbe de notificar o fato aos demais signatários. Basicamente, o processo de conclusão de um tratado internacional atravessa as seguintes fases, cada qual com suas normas próprias e características específicas. : uma inicial, de negociação, um processo "para encontrar uma terceira coisa que nenhuma parte quer, mas ambas as partes podem aceitar"; a de assinatura, cujo ato perdeu importância com o desenvolvimento da ratificação, mas serve como autenticação do texto, podendo ter ainda, um valor político. Uma vez publicado o Decreto Legislativo que aprova o tratado, encerra-se a etapa de apreciação e aprovação e se iniciam os procedimentos para sua confirmação (ratificação) e entrada em vigor. A ratificação do desejo brasileiro de obrigar-se pelo Ato constitui o processo pelo qual o instrumento adquire vigência internacional. É considerada a mais importante do processo de conclusão de tratados, pelo qual a autoridade nacional competente informa as autoridades correspondentes dos Estados participantes da conclusão de um tratado a aprovação desse e sua obrigatoriedade para os Estados. Finalmente, uma vez que o ato haja entrado em vigor internacional, cumpre incorporá-lo ao ordenamento jurídico interno, mediante a 
Os tratados tornam-se obrigatórios para os órgãos judiciais internos a partir da sua promulgação e publicação. Uma vez celebrado e tendo entrado em vigor, o tratado estabelece uma relação jurídica entre Estados, aplicando-se em todo território estatal, desde o momento de sua internalização. FRANCISCO REZEK ${ }^{333}$ ressalta que é importante que se retenha desde logo a noção de que o tratado, embora produzido em foro diverso das fontes legislativas domésticas, não se distingue, enquanto norma jurídica, dos diplomas legais de produção interna. Nas lições de REZEK, sem o prejuízo de sua inafastável internacionalidade, desde quando vigente, o tratado deve compor a ordem jurídica nacional da cada Estado-parte, e poderão garantir-lhe vigência juízes e tribunais, da mesma forma como fazem em relação aos diplomas normativos de produção interna.

A Constituição Federal de 1988 não é clara quanto à posição hierárquica dos tratados internacionais não referentes a direitos humanos. $\mathrm{O}$ artigo 60, incisos I, II e III da Constituição de 1988 não consagra a hierarquia dos tratados internacionais aprovados, ratificados, promulgados e incorporados ao ordenamento jurídico brasileiro. A própria leitura do $\$ 2^{\circ}$ do artigo $5^{\circ}$ da Constituição, ao dispor que: "os direitos e garantias expressos nesta Constituição não excluem outros decorrentes do regime e dos princípios por ela adotados, ou dos tratados internacionais em que a República Federativa do Brasil seja parte”; não configura expressamente aos tratados força de emenda constitucional; não toca na questão da hierarquia, apenas autoriza que o tema dos direitos e garantias possam ser regulados por tratados incorporados pelo Direito brasileiro.

O tema foi questionado pela primeira vez no Supremo Tribunal Federal na oportunidade do julgamento do Habeas Corpus 72.131, julgado em 23 de novembro de 1995, relacionado à compatibilidade da prisão civil do depositário infiel ou equiparado com o artigo $5^{\circ}$, LXVII, da Constituição e com o Pacto de São José, em que o Supremo Tribunal Federal passou a entender que nem todo tratado novo revoga lei anterior que com ele conflite. O Supremo decidiu que a prisão civil

promulgação por meio de Decreto assinado pelo Presidente da República e referendado pelo Ministro das Relações Exteriores, seguido da publicação no Diário Oficial, medida que o incorpora ao direito interno e lhe dá a publicidade exigida pela norma jurídica, e registro junto ao Secretariado das Nações Unidas, conforme o artigo 102 da Carta das Nações Unidas.

${ }^{333}$ REZEK, Francisco. Direito Internacional Público: curso elementar, pp. 78-80. 
do depositário infiel em alienação fiduciária é constitucional, em face da natureza geral do Pacto de San Jose com relação às normas especiais previstas em lei ordinária sobre a prisão civil do depositário infiel passando a adotar o critério da especialidade (lex specialis derogat generalis) para a resolução dos conflitos entre leis internas e tratados internacionais, uma vez que, antes desses julgados, adotava-se apenas o critério cronológico (lex posterior derogat priori). Em suma, a partir do HC $\mathrm{n}^{\mathrm{o}}$ 72.131-RJ, o Supremo Tribunal Federal passou a entender que nem todo tratado novo revoga lei anterior que com ele conflite. Exige-se que além de novo, esteja o tratado apto a revogar a lei anterior, e isso apenas acontece quando ambas as espécies normativas sejam gerais ou ambas sejam especiais. ${ }^{334}$

$\mathrm{Na}$ Medida Cautelar na Ação Direta de Inconstitucionalidade ADI/MC/DF 1.480, julgada em 25/09/1996, com o Ministro Celso de Mello como Relator - tratou-se sobre a constitucionalidade da Convenção 158 da Organização Internacional do Trabalho sobre a proteção do trabalhador contra a despedida arbitrária ou sem justa causa, em que se argüiu a ilegitimidade constitucional dos atos que incorporaram essa convenção internacional ao direito positivo interno do Brasil (Decreto Legislativo $n^{\circ} 68 / 92$ e Decreto $n^{\circ} 1.855 / 96$ ), consagrando-se o direito constitucional à indenização (artigo 7º, I, da Constituição de 1988 e artigo 10, I do Ato das Disposições Constitucionais Transitórias de 1988).

No julgamento da ADI 1.480 decidiu-se que o primado da Constituição de 1988 seria oponível ao princípio pacta sunt servanda, inexistindo, por isso mesmo, no direito positivo nacional, o problema da concorrência entre tratados internacionais e a Carta Política nacional, cuja a autoridade normativa deveria sempre prevalecer sobre os atos de direito internacional público. A própria Carta Política subordina o tratamento legislativo de determinado tema ao exclusivo domínio normativo da lei complementar, que não pode ser substituída por qualquer

\footnotetext{
334 "Habeas corpus. Alienação fiduciária em garantia. Prisão civil do devedor como depositário infiel. - Sendo o devedor, na alienação fiduciária em garantia, depositário necessário por força de disposição legal que não desfigura essa caracterização, sua prisão civil, em caso de infidelidade, se enquadra na ressalva contida na parte final do artigo $5^{\circ}$, LXVII, da Constituição de 1988. - Nada interfere na questão do depositário infiel em matéria de alienação fiduciária o disposto no $\S 7^{\circ}$ do artigo $7^{\circ}$ da Convenção de San José da Costa Rica. "Habeas corpus" indeferido, cassada a liminar concedida." STF. Habeas Corpus 72131/Rio de Janeiro. Relator: Ministro Marco Aurélio, e para o Acórdão, Ministro Moreira Alves. Julgado em 23/11/1995. Órgão Julgador: Tribunal Pleno.
} 
outra espécie normativa infraconstitucional, inclusive pelos atos internacionais já incorporados ao direito positivo interno. ${ }^{335}$

No esntanto, o Supremo Tribunal Federal, no julgamento conjunto do Recurso Extraordinário 349.703/RS, cujo Relator para o acórdão foi o MINISTRO GILMAR MENDES; do Recurso Extraordinário 466.343/SP, sendo Relator o MinISTRO Cezar Peluso; e do Habeas Corpus 87.585/TO, Relator o Ministro Marco AURÉLIO, firmou o entendimento de que, em nosso sistema constitucional, não mais subsiste a possibilidade jurídica de decretação da prisão civil do depositário infiel, inclusive a do depositário judicial, por incompatível com nosso sistema de direitos e garantias consagrado na Constituição e nos tratados internacionais de direitos humanos.

Em conseqüência dessas decisões plenárias, o Supremo Tribunal Federal, no Habeas Corpus 92.566/SP julgado em 09 de outubro de 2007, em que o

335 “Ação Direta de Inconstitucionalidade - Convenção no 158/OIT - Proteção do trabalhador contra a despedida arbitrária ou sem justa causa - argüição de ilegitimidade constitucional dos atos que incorporaram essa convenção internacional ao direito positivo interno do Brasil (Decreto Legislativo $n^{o}$ 68/92 e Decreto $n^{\circ}$ 1.855/96) - Possibilidade de controle abstrato de constitucionalidade de tratados ou convenções internacionais em face da Constituição da República - alegada transgressão ao artigo $7^{\circ}$, I, da Constituição da República e ao artigo 10, I do ADCT/88 - Regulamentação normativa da proteção contra a despedida arbitrária ou sem justa causa, posta sob reserva constitucional de Lei Complementar - conseqüente impossibilidade jurídica de tratado ou convenção internacional atuar como sucedâneo da Lei Complementar exigida pela Constituição (CF, artigo $7^{\circ}$, I) - consagração constitucional da garantia de indenização compensatória como expressão da reação estatal à demissão arbitrária do trabalhador (CF, artigo $7^{\circ}$, I, c/c o artigo 10, I do ADCT/88) conteúdo programático da Convenção $n^{\circ} 158 / O I T$, cuja aplicabilidade depende da ação normativa do legislador interno de cada país - possibilidade de adequação das diretrizes constantes da convenção $n^{o}$ 158/OIT às exigências formais e materiais do estatuto constitucional brasileiro - pedido de medida cautelar deferido, em parte, mediante interpretação conforme à Constituição. Procedimento constitucional de incorporação dos tratados ou convenções internacionais. (...) Legitimidade constitucional da convenção $n^{\circ} 158 / O I T$, desde que observada a interpretação conforme fixada pelo Supremo Tribunal Federal. A Convenção $n^{\circ}$ 158/OIT, além de depender de necessária e ulterior intermediação legislativa para efeito de sua integral aplicabilidade no plano doméstico, configurando, sob tal aspecto, mera proposta de legislação dirigida ao legislador interno, não consagrou, como única conseqüência derivada da ruptura abusiva ou arbitrária do contrato de trabalho, o dever de os Estados-Partes, como o Brasil, instituírem, em sua legislação nacional, apenas a garantia da reintegração no emprego. Pelo contrário, a Convenção $n^{o}$ 158/OIT expressamente permite a cada Estado-Parte (Artigo 10), que, em função de seu próprio ordenamento positivo interno, opte pela solução normativa que se revelar mais consentânea e compatível com a legislação e a prática nacionais, adotando, em conseqüência, sempre com estrita observância do estatuto fundamental de cada País (a Constituição brasileira, no caso), a fórmula da reintegração no emprego elou da indenização compensatória. Análise de cada um dos Artigos impugnados da Convenção $n^{\circ}$ 158/OIT (Artigos $4^{\circ}$ a 10)". ADI 1480 MC/DF - Distrito Federal. Medida Cautelar na Ação Direta de Inconstitucionalidade. Relator: Min. Celso de Mello. Julgamento: 04/09/1997. Órgão Julgador: Tribunal Pleno. 
Ministro MARCo AURÉLIO atuou como Relator, declarou expressamente a revogação da Súmula 619/STF de 17 de outubro de 1984, que autorizava a decretação da prisão civil do depositário infiel no próprio processo em que se constitui o encargo, independentemente do prévio ajuizamento da ação de depositário.

No Recurso Extraordinário 466.343-1 SP julgdo em 13 de dezembro de $2008^{336}$, o Ministro GILMAR MENDES, oportunamente, assinalou a importância das mudanças decorrentes da Constituição de 1988, que aponta para a insuficiência da tese da igualdade ordinária dos tratados já ratificados pelo Brasil. Ele explicou que a tese da legalidade ordinária dos tratados internalizados pelo Brasil permitiria o descumprimento unilateral de um tratado, contradizendo o artigo 27 da Convenção de Viena sobre Direito dos Tratados de $1969 .{ }^{337}$ Alem do mais, o Minitro considerou que a supralegalidade dos tratados de direitos humanos seria mais consistente. Ainda que infraconstitucionais, o caráter dos tratados de direitos humanos é especial em

336 "Desde a promulgação da Constituição de 1988, surgiram diversas interpretações que consagraram um tratamento diferenciado aos tratados relativos a direitos humanos, em razão do disposto no $\$ 2^{\circ}$ do artigo $5^{\circ}$, que afirma que os direitos e garantias expressos nesta Constituição não excluem outros decorrentes do regime e dos princípios por ela adotados, ou dos tratados internacionais em que a República Federativa do Brasil seja parte. Essa disposição constitucional deu ensejo a uma instigante discussão doutrinária e jurisprudencial sobre o status normativo dos tratados internacionais de direitos humanos, sistematizados nas seguintes correntes: 1) a vertente que reconhece a natureza supraconstitucional dos tratados e convenções em matéria de direitos humanos, em que nem mesmo uma Emenda Constitucional teria o condão de suprimir uma norma de direitos humanos (MELLO, Celso Duvivier de Albuquerque. $\boldsymbol{O} \$ 2^{\circ}$ do artigo $5^{\circ}$ da Constituição Federal. In. TORRES, Ricardo Lobo (Org.) Teoria dos Direitos Fundamentais. Rio de Janeiro: Renovar, 1999, pp. 25-26); 2) a posição que atribui caráter constitucional a esses diplomas internacionais, que entende o $\$ 2^{\circ}$ do artigo $5^{\circ}$ da Constituição como uma cláusula aberta de recepção de outros direitos por meio de tratados, com aplicação imediata no plano nacional, e aplicação da norma mais favorável à vítima em caso de conflito com outra norma constitucional; 3) a tendência que reconhece o status de lei ordinária a esse tipo de documento internacional (PIOVESAN, Flávia. Direitos Humanos e o Direito Constitucional Internacional. São Paulo: Max Limonad, 1996, p. 83); 4) por fim, a interpretação que atribui caráter supralegal aos tratados internacionais de direitos humanos. Ele salienta a dificuldade de adequar essas teorias à realidade do Brasil cujo sistema jurídico é regido pelo princípio da supremacia formal e material da Constituição. Daí, quando ao treaty-making power, os tratados internacionais devem ser celebrados em consonância com o procedimento formal descrito na Constituição, e com respeito ao seu conteúdo material, sobretudo em tema de direitos e garantias fundamentais - é o controle da constitucionalidade." "Prisão Civil. Depósito. Depositário infiel. Alienação fiduciária. Decretação da medida coercitiva. Inadmissibilidade absoluta. Insubsistência da previsão constitucional e das normas subalternas. Interpretação do artigo $5^{\circ}$, inc. LXVII e $\$ \S 1^{o}, 2^{o} e$ $3^{\circ}$, da CF, à luz do artigo $7^{\circ}$, $\$ 7$, da Convenção Americana de Direitos Humanos (Pacto de San José da Costa Rica). Recurso improvido. Julgamento conjunto do RE $n^{\circ} 349.703$ e dos HCs $n^{\circ} 87.585$ e $n^{o}$ 92.566. É ilícita a prisão civil de depositário infiel, qualquer que seja a modalidade do depósito." STF. Recurso Extraordinário. 466343/SP - São Paulo. Relator: Ministro Cezar Peluso. Julgamento: 03/12/2008. Órgão Julgador: Tribunal Pleno.

${ }^{337}$ A Convenção de Viena sobre o Direito dos Tratados dos Tratados, na ocasião, não estava em vigor internamente, o que ocorreu apenas em 2009, com a promulgação do Decreto $\mathrm{n}^{\circ} 7.030$, de 14 de dezembro de 2009. 
relação aos demais atos normativos internacionais. Não podem afrontar a Constituição Federal, mas possuem espaço especial reservado no ordenamento jurídico brasileiro. Equipará-los à legislação ordinária seria subestimar o seu valor especial no contesto do sistema de proteção dos direitos da pessoa humana.

A Emenda Constitucional n. ${ }^{\circ}$ 45/2004 (Reforma do Judiciário) autoriza que os tratados internacionais de direitos humanos tenham status de emenda constitucional, desde que seguido o procedimento contemplado no $\S 3^{\circ}$ do artigo $5^{\circ}$ da Constituição Federal, que dispõe que "os tratados e convenções internacionais sobre direitos humanos que forem aprovados, em cada Casa do Congresso Nacional, em dois turnos, por três quintos dos votos dos respectivos membros, serão equivalentes às emendas constitucionais". Assim, solucionada as discussões relativas à hierarquia dos tratados internacionais de direitos humanos no ordenamento jurídico pátrio para o futuro. A mudança constitucional ao menos acena para a insuficiência da tese da legalidade ordinária dos tratados já ratificados pelo Brasil, preconizada pela jurisprudência do Supremo Tribunal Federal desde o remoto julgamento do Recurso Extraordinário n. ${ }^{\circ}$ 80.004/SE, em 01/06/1977. ${ }^{338}$

Discussões doutrinárias à parte, o fato é que a questão sobre a hierarquia dos tratados no Direito brasileiro já está consagrada pela jurisprudência do Supremo Tribunal Federal. O propósito principal aqui, no entanto, é chamar atenção para uma reflexão quanto ao status de tratado incorporado ao direito interno brasileiro, no caso a Convenção de Viena sobre Relações Consulares de 1963, que não é tradicionalmente considerado como de direitos humanos, mas que a Corte Interamericana de Direitos Humanos, por meio de uma interpretação evolutiva, reconheceu que prevê, em seu artigo 36, direito que compõe o corpus iuris dos direitos humanos, no que tange ao pacote das garantias mínimas do devido processo lega. O principal desafio desta pesquisa, no entanto, é o estudo da relação desse tratado com a legislação que rege o direito processo penal, porque envolve uma interação entre internacionalistas e processualistas.

338 STF. Recurso Extraordinário. 466343/SP - São Paulo. Relator: Ministro Cezar Peluso. Julgamento: 03/12/2008. Órgão Julgador: Tribunal Pleno. Voto do Ministro Gilmar Mendes, pp. 1144-1146. 


\section{2. - Incorporação dos direitos previstos pelo artigo 36 da Convenção de Viena sobre Relações Consulares de 1963 no ordenamento positivo interno brasileiro - análise da Constituição Federal e da legislação processual penal vigente}

Esta etapa envolve o estudo reflexivo, a partir da perspectiva contemporânea de Direito Internacional Público, sobre o status no Direito brasileiro de tratado , in casu a Convenção de Viena sobre Relações Consulares, de 1963, mas que a Corte Internacional de Justiça e a Corte Interamericana de Direitos Humanos reconhece que prevê direitos que se referem ao indivíduo. A indagação maior que se faz aqui é qual seria o efeito da interpretação dada por essas cortes internacionais no Direito constitucional e processual penal brasileiro, notadamente no que diz respeito ao acervo que congrega as regras de garantias processuais quando se trata de um estrangeiro submetido a um procedimento penal e privado de liberdade.

Celebrada em Viena, em 24 de abril de 1963, a Convenção foi assinada pelo Brasil em 24 de abril do mesmo ano e recepcionada por força da promulgação do Decreto $n^{\circ}$ 61.078, de 26 de julho de 1967, sendo fonte soberana de direito público, de plena e irrestrita vigência interna. No entanto, o Brasil não ratificou o Protocolo Opcional à Convenção de Viena de 1963, que permite a intervenção da Corte quando houver violação.

Considerando o entendimento jurisprudencial do Supremo Tribunal Federal, a Convenção de Viena de 1963 tem validade e executoriedade no território nacional com o igual status de lei ordinária, por não ser tratado especificamente de direitos humanos. Assim, sequer recebe o tratamento diferenciado da supralegalidade, como recebem os tratados de direitos humanos que foram incorporados pelo Brasil anteriormente à Emenda Constitucional n. ${ }^{0}$ 45/2004. No entanto, a Corte Interamericana de Direitos Humanos, cuja jurisdição o Brasil reconhece, decidiu pelo impacto direto exercido pela dinâmica do Direito Internacional dos Direitos Humanos no artigo 36 da Convenção. ${ }^{339}$ É nesse contexto

\footnotetext{
${ }^{339}$ Opinión Consultiva OC-16/99 del 1 de octubre de 1999. El Derecho a la Información sobre la Asistencia Consular en el Marco de las Garantías del Debido Proceso Legal, Voto concordante do Juiz CANÇADO TRINDADE, $\S 13$.
} 
que é sugerido nesta Dissertação que o direito de informação sobre assistência consular para preso estrangeiro deve ser, no Direito brasileiro, considerado como componente do rol das garantias processuais-constitucionais, com fundamento tanto no inciso LXIII como no $\S 2^{\circ}$, ambos do artigo $5^{\circ}$ da Constituição Federal, levandose em consideração também a legislação penal e processual penal em vigor.

A Constituição Federal, no âmbito dos direitos e garantias fundamentais, dispõe sobre presos, lembrando que essas normas têm aplicação imediata, são auto-aplicáveis, e não excluem outros direitos decorrentes do regime e dos princípios por ela adotados, ou dos tratados internacionais em que o Brasil seja parte. Em linha com seu fundamento de proteção à dignidade da pessoa humana $\mathrm{e}$ igualdade de todos perante a lei, no caput do artigo $5^{\circ}$ da Constituição Federal de 1988 garantiu-se expressamente ao brasileiro e estrangeiro residente no País a inviolabilidade do direito à vida, à liberdade, à igualdade, à segurança e à propriedade: "Todos são iguais perante a lei, sem distinção de qualquer natureza, garantindo-se aos brasileiros e aos estrangeiros residentes no País a inviolabilidade do direito à vida, à liberdade, à igualdade, à segurança e à propriedade, nos termos seguintes (...)”. Esse dispositivo estabelece as garantias constitucionais-processuais, que também se estendem ao estrangeiro, com fundamento nos princípios da dignidade humana e igualdade. ${ }^{340}$

A Constituição deve ser compreendida como unidade e como sistema que privilegia determinados valores sociais, e a brasileira elege a dignidade da pessoa humana como valor essencial que dá sentido a todo ordenamento jurídico. O valor da dignidade da pessoa humana, bem como o valor dos direitos e garantias

340 "Penal. Estrangeiro. Prisão Preventiva. Excesso de prazo. Crime hediondo. Interpretação preconceituosa. 1. As razões de Estado, em se tratando de direito individual de qualquer pessoa neste país, brasileiro ou estrangeiro, não podem transcender aos limites da Constituição da República. 2. As leis penais, que como quaisquer outras têm que se conformar com os mandamentos constitucionais, sob pena de não valerem nada, não podem ser interpretadas preconceituosamente, ao sabor de cada situação. 3. Havendo excesso de prazo a que não deu causa a defesa, configura-se o constrangimento ilegal. É a maneira da lei, denunciando a desídia dos agentes do poder público, estancar a coação ilegal que se perpetra em nome do Estado. 4. A existência de prisão preventiva não acoberta o excesso de prazo injustificável a que não deu causa a defesa. 5. Não sendo o pedido de liberdade provisória com ou sem fiança, nem de nulidade de prisão em flagrante substituível por prisão preventiva, inaceitável desviar-se a questão para a Lei dos Crimes Hediondos, insuscetíveis de fiança e de liberdade provisória, nem para questão de cabimento, no caso, de prisão preventiva. 6. Recurso conhecido e provido parcialmente para que o acusado aguarde o julgamento em liberdade vigiada". STJ - RHC n. 3.729-SP - 5 ${ }^{\text {a }}$ Turma - julgado em 22/6/94 - Relator Ministro Edson Vidigal. 
fundamentais, cláusulas pétreas, conforme o artigo 60, § IV da Constituição, incorporam as exigências de justiça e dos valores éticos, conferindo suporte axiológico a todo sistema jurídico brasileiro. A Carta de 1988 acolhe o princípio da indivisibilidade e interdependência dos direitos humanos, pelo qual o valor da liberdade se conjuga com o da igualdade. ${ }^{341}$

A Constituição, no artigo $4^{\circ}$, II, elenca o princípio da prevalência dos direitos humanos como princípio fundamental a reger o Brasil nas relações internacionais, o que também envolve a busca plena da integração das regras do Direito Internacional dos Direitos Humanos na ordem jurídica interna brasileira. Assim, rompe-se com a concepção tradicional de soberania estatal absoluta, em prol da proteção dos direitos humanos. Esse é um processo condizente com as exigências do Estado Democrático de Direito constitucionalmente pretendido. ${ }^{342}$

A relação entre Direito Internacional e direito interno sempre instigou debates puramente doutrinários, mas que ainda traz problemas práticos, por conta da crescente adoção de tratados cujo escopo refere-se às relações entre os Estados e seus cidadãos. Para Flavia PiOvesAN ${ }^{343}$ o o $§ 2^{\circ}$ do artigo $5^{\circ}$ da Constituição seria uma "cláusula constitucional aberta", que permite sua flexibilidade necessária ao contínuo desenvolvimento político, ao prescrever que "os direitos e garantias expressos na Constituição não excluem outros direitos decorrentes dos tratados internacionais". Isso implicaria a incorporação pelo texto constitucional desses direitos e garantias previstos em outros tratados, em face também da força expansiva dos valores da dignidade humana e dos direitos fundamentais, como parâmetros axiológicos a orientar a compreensão do fenômeno constitucional. A Carta garante a esses tratados que conferem direitos e garantias o valor jurídico de norma constitucional, porque esses preenchem e complementam o catálogo de direitos fundamentais previstos no Texto Constitucional. Os direitos e garantias previstas em outros tratados internacionais integrariam o "bloco da constitucionalidade".

\footnotetext{
${ }^{341}$ PiOves An, Flavia. Direitos Humanos e o Direito Constitucional Internacional, pp. 26-37.

${ }^{342}$ PIOVESAN, Flavia. Direitos Humanos e o Direito Constitucional Internacional, pp. 40-41.

${ }^{343}$ PIOVESAN, Flavia. Direitos Humanos e o Direito Constitucional Internacional, pp. 51-59.
} 
AleXANDRE DE MORES ${ }^{344}$, em comentários ao $\S 2^{\circ}$ do $\operatorname{artigo} 5^{\circ}$ da Constituição Federal de 1988, observa que os direitos e garantias expressos na Constituição não excluem outros de caráter constitucional decorrentes do regime e dos princípios por ela adotados, mesmo fora do rol do artigo $5^{\circ}$, "que é meramente exemplificativo". Ele ressalta que as normas constitucionais cuja natureza jurídica configure-se como direito ou garantia individual, ainda que não descritas no rol do artigo $5^{\circ}$ da Magna Carta, são inadmissíveis em emendas tendentes a suprimi-las, total ou parcialmente - são cláusulas pétreas (Constituição de 1988, artigo 60, § 4º, IV).

Dispõe o artigo 5, caput, da Constituição Federal de 1988: “Todos são iguais perante a lei, sem distinção de qualquer natureza, garantindo-se aos brasileiros e aos estrangeiros residentes no País a inviolabilidade do direito à vida, à liberdade, à igualdade, à segurança e à propriedade, nos termos seguintes (...)”. Quanto aos direitos dos "estrangeiros residentes", JosÉ AFONSO E SILVA ressalta não restar dúvidas que a eles destinam-se todos os direitos e garantias fundamentais arrolados no artigo $5^{\circ}$. Cabem-lhes os direitos sociais, especialmente os trabalhistas. Seria contrário aos direitos fundamentais do homem negá-los aos estrangeiros residentes aqui. No entanto, não é fácil delinear o alcance desses direitos com relação aos estrangeiros não residentes no País, haja vista que só se mencionam os "estrangeiros residentes", sem falar os estrangeiros em situação irregular no País. Ao pé da letra, até poder-se-ia subentender que o estrangeiro não residente não gozaria de nenhum dos direitos e garantias nele enunciados, o que não é verdade. ${ }^{345}$

AFONSO DA SILVA ressalta que para proteger os estrangeiros, inclusive os não residentes: "há outras normas jurídicas, inclusive de Direito Internacional, que o Brasil e suas autoridades têm que respeitar e observar, assim como existem normas legais, traduzidas em legislação especial, que definem os direitos e a condição jurídica do estrangeiro não residente, que tenha ingressado regularmente no território brasileiro”. E que o fato de a Constituição não incluir os estrangeiros não residentes não justifica sequer a possibilidade de legislação ordinária abusiva em

\footnotetext{
${ }^{344}$ MORAES, Alexandre de. Constituição do Brasil Interpretada e legislação constitucional, pp. 406-408.

${ }^{345}$ Silva, José Afonso da. Curso de Direito Constitucional Positivo, pp. 192 e 193.
} 
relação a eles, uma vez que, "além da existência de normas de Direito Internacional vinculantes, o Brasil é ainda subscritor das declarações universal e americana de direitos humanos, o que, agora, até por força do $\$ 2^{\circ}$ do artigo $5^{\circ}$, lhe impõe, quando nada, a consideração de que a pessoa humana tem uma dimensão supranacional que mereceu um mínimo de respeito e postula um tratamento condigno, ao menos no que tange àqueles direitos de natureza personalíssima". E quando a própria Constituição em seu artigo $1^{\circ}$ insere a dignidade da pessoa humana como um dos fundamentos do Estado Democrático de Direito, proclama o valor universal e abrangente do ser humano. Sem falar que o descumprimento destas obrigações, de respeitar o princípio da igualdade e não-discriminação, gera a responsabilidade internacional do Estado e é ainda mais grave na medida em que esse descumprimento viola normas peremptórias do Direito Internacional dos Direitos Humanos. Assim, a obrigação geral de respeitar e garantir os direitos humanos vincula a todos os Estados, independentemente de qualquer circunstância ou consideração como nacionalidade. ${ }^{346}$

O professor ANDRÉ DE CARVALHO RAMOS, ressalta que, literalmente, a Constituição limitou ao "estrangeiro residente" a titularidade de direitos fundamentais. No entanto, essa restrição ofende os princípios basilares de um Estado Democrático de Direito (artigo $1^{\circ}$ ), porque permitiria a privação de direitos fundamentais do estrangeiro em território brasileiro. Ele explica que é pacífico o entendimento da doutrina quanto à extensão da titularidade de direitos fundamentais a todos os estrangeiros, inclusive aos não residentes no Brasil. O próprio Estado Democrático de Direito fundado pela Constituição de 1988 não admitiria a privação de direitos fundamentais com base no critério da "não-residência".

Tratar os estrangeiros não-residentes como desprovidos de direitos fundamentais ofende o princípio constitucional da promoção da dignidade humana (artigo $1^{\circ}$, inciso III). Sem falar do reconhecimento pela Constituição de 1988 dos denominados direitos decorrentes dos tratados internacionais de direitos humanos que o Brasil é parte (artigo $5^{\circ}, \S 2^{\circ}$ ), como o Pacto Internacional de Direitos Civis e

\footnotetext{
346 Corte Interamericana de Direitos Humanos. Condição Jurídica e Direitos dos Migrantes Indocumentados. Opinião Consultiva OC-18/03, de 17 de setembro de 2003. Serie A N N $^{\circ}$ 18, parag. 106.
} 
Políticos ou a Convenção Americana de Direitos Humanos, que entendem que a titularidade dos direitos fundamentais se estende a todos, inclusive para os estrangeiros, residentes ou não. ${ }^{347}$

Com relação aos estrangeiros em situação irregular no Estado Receptor, a Corte Interamericana, na Opinião Consultiva n. ${ }^{\circ}$ 18, de 17 de setembro de 2003, manifestou que o princípio da igualdade perante a lei e a sua nãodiscriminação emprega toda a atuação do Estado, em qualquer de suas manifestações, relacionada com o respeito e garantia dos direitos humanos. É considerado efetivamente como imperativo do Direito Internacional Geral, aplicável a todos os Estados, parte, ou não, de determinado tratado internacional e, portanto, gera efeitos com respeito a terceiros, inclusive particulares.

A obrigação geral de respeitar e garantir os direitos humanos vincula os Estados, independentemente de qualquer circunstância ou consideração, "inclusive el estatus migratorio de las personas". A Corte também considerou que o direito ao devido processo legal deve ser reconhecido no marco das garantias mínimas que devem brindar todo imigrante, independentemente da situação migratória. O amplo

\footnotetext{
${ }^{347}$ CARValho Ramos, André de. Direitos dos Estrangeiros no Brasil: imigração, direito de ingresso e os direitos dos estrangeiros em situação irregular, pp. 730 e 731. Cita-se o artigo 24 da Convenção Americana de Direitos Humanos, que trata da Igualdade Perante a Lei: "Todas as pessoas são iguais perante a lei. Por conseguinte, têm direito, sem discriminação, a igual proteção da lei." O artigo II da Declaração Americana dos Direitos do Homem dispõe que: "Todas as pessoas são iguais perante a lei e têm os direitos e deveres consagrados nesta Declaração, sem distinção de raça, língua, crença ou qualquer outra." O artigo $3^{\circ}, 1$, da Carta da Organização dos Estados Americanos prevê que "Os Estados americanos proclamam os direitos fundamentais da pessoa humana, sem fazer distinção de raça, nacionalidade, credo ou sexo". O artigo 17 do mesmo documento estabelece que "Cada Estado tem o direito de desenvolver, livre e espontaneamente, a sua vida cultural, política e econômica. No seu livre desenvolvimento, o Estado respeitará os direitos da pessoa humana e os princípios da moral universal." O artigo 26 do Pacto Internacional sobre Direitos Civis e Políticos dispõe que "Todas as pessoas são iguais perante a lei e têm direito, sem discriminação alguma, a igual proteção da lei. A este respeito, a lei deverá proibir qualquer forma de discriminação e garantir a todas as pessoas proteção igual e eficaz contra qualquer discriminação por motivo de raça, cor, sexo, língua, religião, opinião política ou de outra natureza, origem nacional ou social, situação econômica, nascimento ou qualquer outra situação." O Comitê de Direitos Humanos da ONU definiu a discriminação como: “(...) toda distinção, exclusão, restrição ou preferência que se baseie em determinados motivos, como a raça, a cor, o idioma, a religião, a opção política ou de outra índole, a origem nacional ou social, a posição econômica, o nascimento ou qualquer outra condição social, e que tenham por objeto ou por resultado, anular ou menoscabar o reconhecimento, gozo ou exercício, em condições de igualdade, dos direitos humanos e liberdades fundamentais de todas as pessoas." ONU, Comitê de Direitos Humanos, Observação Geral 18, Não discriminação, 10/11/89, CCPR/C/37, par. 7.
} 
alcance da intangibilidade do devido processo aplica-se apenas ratione materiae e ratione personae, sem discriminação nenhuma. ${ }^{348}$

O princípio da igualdade e não-discriminação pertence ao domínio do jus cogens, donde descansa todo o andaime jurídico da ordem pública nacional e internacional. É um princípio fundamental que permeia todo ordenamento jurídico e acarreta obrigações erga omnes de proteção, que vincula a todos os Estados, gerando efeitos frente a terceiros e particulares. Hoje não se admite nenhum ato jurídico que entre em conflito com o princípio da igualdade e não-discriminação; não se admitem tratos discriminatórios em prejuízo de qualquer pessoa, por motivos de raça, gênero, cor, idioma, religião ou convicção, opinião política, origem nacional, ética ou social, nacionalidade, idade, situação econômica, patrimônio, estado civil, nascimento ou qualquer outra condição. Existe um vínculo indissociável entre a obrigação de respeitar e garantir os direitos humanos, e o princípio de igualdade e não discriminação. ${ }^{349}$

O fundamento de proteção à igualdade de todos perante a lei, no caput do artigo $5^{\circ}$ da Constituição Federal de 1988, garante expressamente ao brasileiro e estrangeiro a inviolabilidade do direito à vida, à liberdade, à igualdade, à segurança e à propriedade. Qualquer discriminação baseada em critério da "não-residência" afronta o Estado Democrático de Direito fundado no artigo $1^{\circ}$ da nossa Constituição, baseado na dignidade da pessoa humana. O Supremo Tribunal Federal consagrou que o súdito estrangeiro, mesmo aquele sem domicílio no Brasil, tem direito a todas as prerrogativas básicas que lhe assegurem a preservação do "status libertatis" e a observância, pelo poder público, da cláusula constitucional do "due process". 350

348 Corte Interamericana de Direitos Humanos. Condição Jurídica e Direitos dos Migrantes Indocumentados. Opinião Consultiva n. ${ }^{\circ}$ 18/03, de 17 de setembro de 2003. Serie A N ${ }^{\circ}$. 18, parag. 106 e 122.

349 Corte Interamericana de Direitos Humanos. Condição Jurídica e Direitos dos Migrantes Indocumentados. Opinião Consultiva n. ${ }^{\circ}$ 18/03, de 17 de setembro de 2003. Serie A N ${ }^{\mathrm{o}}$. 18, parags. $85,100-107$.

350 “(...) O súdito estrangeiro, mesmo aquele sem domicílio no Brasil, tem direito a todas as prerrogativas básicas que lhe assegurem a preservação do "status libertatis" e que lhe garantam a observância, pelo poder público, da cláusula constitucional do "due process". O súdito estrangeiro, mesmo o não domiciliado no Brasil, tem plena legitimidade para impetrar o remédio constitucional do "Habeas Corpus", em ordem a tornar efetivo, nas hipóteses de persecução penal, o direito subjetivo, de que também é titular, à observância e ao integral respeito, por parte do Estado, das prerrogativas que compõem e dão significado à cláusula do devido processo legal. A condição 
A condição jurídica de estrangeiro no Brasil e a circunstância de ser acusado um crime e não residir no país não legitimam a adoção contra o estrangeiro de qualquer tratamento arbitrário ou discriminatório. E, ainda, impõe-se ao Judiciário o dever de assegurar ao estrangeiro nessa situção os direitos básicos que resultam do postulado do devido processo legal, notadamente as prerrogativas inerentes à garantia da ampla defesa, à garantia do contraditório, à igualdade entre as partes perante o juiz natural e à garantia de imparcialidade do magistrado processante. A expressão "residente no Brasil" deve ser interpretada no sentido de que a Constituição só pode assegurar a validade e o gozo dos direitos fundamentais dentro do território brasileiro. ${ }^{351}$

$\mathrm{Na}$ verdade, os estrangeiros submetidos a um procedimento penal, especialmente quando se vêem privados de liberdade, devem contar com medidas que lhes permitam um verdadeiro e pleno acesso à justiça. Não basta que a lei lhes reconheça os mesmos direitos que os demais indivíduos nacionais do Estado em que segue o juízo, mas devem comparecer em pé de igualdade perante a justiça, sem as graves limitações que implicam a estranheza cultural, a ignorância do idioma, o desconhecimento do sistema processual, e outras restrições de suas possibilidades de

jurídica de não nacional do Brasil e a circunstância de o réu estrangeiro não possuir domicílio em nosso país não legitimam a adoção, contra tal acusado, de qualquer tratamento arbitrário ou discriminatório. Precedentes (HC 94.016/SP, Rel. Min. Celso de Mello, v.g.). Impõe-se, ao Judiciário, o dever de assegurar, mesmo ao réu estrangeiro sem domicílio no Brasil, os direitos básicos que resultam do postulado do devido processo legal, notadamente as prerrogativas inerentes à garantia da ampla defesa, à garantia do contraditório, à igualdade entre as partes perante o juiz natural e à garantia de imparcialidade do magistrado processante. (...)" Habeas Corpus 102041/SP - São Paulo. STF. Relator: Ministro Celso de Mello. Julgado em: 20/04/2010. Órgão Julgador: Segunda Turma.

351 "Direitos e Garantias Fundamentais - estrangeiros - A teor do disposto na cabeça do artigo $5^{\circ}$ da Constituição Federal, os estrangeiros residentes no País têm jus aos direitos e garantias fundamentais. Prisão preventiva - excesso de prazo - Uma vez configurado o excesso de prazo, cumpre, em prol da intangibilidade da ordem jurídica constitucional, afastar a custódia preventiva. Idas e vindas do processo, mediante declarações de nulidade, não justificam a manutenção da custódia do Estado. O mesmo acontece se o acusado é estrangeiro. Evasão do território nacional corre à conta do poder de polícia, presumindo-se esteja o Estado aparelhado para coibi-la. Prisão Recurso da Defesa - inviabilidade - Exsurge conflitante com a proibição legal de chegar-se à reforma prejudicial ao recorrente decretar-se prisão, na oportunidade do julgamento do recurso da defesa, ainda que isso ocorra via provimento judicial no sentido da nulidade do processo no qual imposta, inicialmente, a custódia - Precedente: habeas-corpus $n^{\circ}$ 70.308-ES, relatado pelo Ministro Sepúlveda Pertence perante a Primeira Turma, cujo acórdão restou publicado na Revista Trimestral de Jurisprudência $n^{o}$ 152/170.STF." Habeas Corpus 74051/SC - Santa Catarina. Relator: Ministro Marco Aurélio. Julgado em 18/06/1996. Órgão Julgador: Segunda Turma. 
defesa, sendo necessárias "vias de compensação" que garantam o acesso à justiça, e conteúdo real ao devido processo legal. ${ }^{352}$

Seguindo a proposta de analisar a incorporação dos dispositivos da Convenção de Viena de 1963, verifica-se que nos incisos do artigo $5^{\circ}$ referentes às garantias constitucionais-processuais não há menção expressa ao "preso estrangeiro", muito menos no que diz respeito ao direito de informação sobre a assistência consular, nos termos do artigo 36 da Convenção de Viena de 1963. O inciso LXIII do artigo $5^{\circ}$ da Constituição estabelece os direitos "do preso", sem especificar sua nacionalidade: "o preso será informado de seus direitos, entre os quais o de permanecer calado, sendo-lhe assegurada a assistência da família e de advogado."

Nenhuma jurisprudência do Supremo Tribunal Federal foi encontrada sobre o direito de informação sobre a assistência consular para preso estrangeiro, muito menos considerando expressamente esse direito como sendo um componente do rol que compõe as garantias judiciais do devido processo legal, notadamente relacionado ao direito de ampla defesa. ${ }^{353}$

Infraconstitucionalmente, tampouco há vigente uma disposição expressa sobre os direitos do preso estrangeiro de ser informado sobre o direito de receber assistência consular por parte do Consulado de sua nacionalidade. $\mathrm{O}$ artigo $1^{\mathrm{o}}$ do Código de Processo Penal dispõe que "o processo penal reger-se-á, em todo o território brasileiro, por este Código, ressalvados: I- os tratados, as convenções e regras de direito internacional." Determina em suas disposições preliminares, o princípio da territorialidade. Significa que a lei processual penal brasileira é aplicada a todo delito ocorrido em território nacional. Esse mesmo princípio é previsto pelo

\footnotetext{
${ }^{352}$ Opinión Consultiva OC-16/99 del 1 de octubre de 1999. El Derecho a la Información sobre la Asistencia Consular en el Marco de las Garantías del Debido Proceso Legal, Voto concordante do JUIZ SÉRGIO GARCIA RAMIREZ, pp. 02 e 03.

${ }^{353}$ Fevereiro de 2011. A maioria da jurisprudência encontrada com o item "consular" pesquisado como referência tem a ver com temas como Extradição; imunidade de jurisdição em caso de execução fiscal ou prisão preventiva contra Cônsul estrangeiro, e outras ações como reparação de danos, causas trabalhistas; divórcio e casamento de brasileiros no estrangeiro; autenticação consular de sentença estrangeira em pedidos de homologação; autenticação de carta rogatória; isenção tributária; imunidades e privilégios dos Cônsules Honorários.
} 
Código Penal. Ademais da regra da territorialidade, o processo penal brasileiro será regido pelos tratados internacionais os quais o Brasil é parte, e também pelas demais regras de Direito Internacional não abrangidas por aqueles, como costumes, princípios gerais aceitos pelas grandes maiorias das nações, na aplicação de seu direito interno, além das decisões tomadas pelas organizações internacionais.. ${ }^{354}$

Apesar do princípio da igualdade, os estrangeiros detidos no Brasil não são prejudicados apenas com a falta de instrumentos que lhes assegurem direitos mínimos garantidos na Constituição e na legislação processual penal em vigor, mas principalmente pela falta de efetiva assistência dos consulados de seus países de origem. No estado de São Paulo, existe uma Penitenciária específica para receber os presos estrangeiros do sexo masculino, localizada no município de Itaí, a Penitenciária “CABo PM Marcelo Pires da Silva”. Ocorre que o Presídio está situado a cerca de 300 kilômetros de distância da capital, ficando os presos estrangeiros afastados dos seus consulados, das suas famílias, do aeroporto internacional mais próximo por onde chegam seus familiares do exterior, dificultando-se, assim, o pouco contato que talvez possam ter com alguém familiar. A grande maioria foi presa por tráfico de substância entorpecente, muitos deles conhecidos como "mulas", além de tráfico de seres humanos, falsificação de documentos de viagem, uso de passaporte falso, trabalho escravo de estrangeiros, roubos, furtos e sequestros. Na maioria das vezes são presos em flagrante delito.

O principal problema dessa população carcerária estrangeira é garantir seus direitos. É que, no plano da execução da pena, benefícios tais como o livramento condicional, a progressão do regime penal de fechado para semi-aberto, sursis ou garantia de visita íntima ainda não são plenamente concedidos pelos tribunais internos aos estrangeiros. A fundamentação é por vezes discriminatória, por não serem residentes no Brasil, como se não se submetessem, por isso, aos cânones constitucionais da isonomia, legalidade, individualização e humanidade da pena ${ }^{355}$.

\footnotetext{
${ }^{354}$ NuCCI, Guilherme de Souza. Código de Processo Penal Comentado, pp. 61-63.

${ }^{355}$ Perante a Constituição, o princípio da individualização da pena compreende: 1)proporcionalidade entre o crime praticado, e a sanção abstratamente cominada no preceito secundário da norma penal; 2) individualização da pena em conformidade com o ato singular praticado por agente em concreto (dosimetria da pena); 3) individualização da sua execução conforme a dignidade humana (CF, artigo $1^{\circ}$, III), o comportamento do condenado no cumprimento da pena (privativa ou não de liberdade), e à
} 
Ademais, a existência de Decreto de Expulsão pode ser fator impeditivo para o livramento condicional. ${ }^{356}$

A maior dificuldade do estrangeiro parece ser conseguir os benefícios do livramento condicional, progressão para o regime aberto, e Indulto, porque o estrangeiro que é condenado no Brasil não pode ficar morando no País. Por isso, o estrangeiro que foi condenado precisa acelerar seu processo de expulsão, que corre no Ministério da Justiça, em Brasília, uma das três situações de saída compulsória do estrangeiro do território nacional (deportação, extradição e expulsão) que aqui entrou regularmente, para promover a reabilitação social de O Estatuto do Estrangeiro cuida do instituto da expulsão no Título VIII dos artigos. 65 ao 75. Com a expulsão, o estrangeiro que satisfizer os requisitos legais pode pedir os benefícios. Se concedidos, o estrangeiro será encaminhado à Polícia Federal para ser levado embora do País. "Expulsão" é um ato administrativo que era da competência da Presidência da República até a emissão do Decreto $n^{\circ} 3447$, de 5 de maio de 2000, que delegou competência ao Ministro da Justiça, para decidir sobre a expulsão de estrangeiro do País e sua revogação.

$\mathrm{O}$ ato de expulsão consiste na retirada compulsória de um estrangeiro do território nacional, devido à prática de um crime que tenha cometido no Brasil, condenados permitindo que cumpram suas sentenças no país de que são nacionais, ou por conduta incompatível com os interesses nacionais. Uma vez expulso, o estrangeiro está impedido de retornar ao nosso país, exceto se revogado o Decreto que determinou a medida. Expulso, o estrangeiro satisfizer os requisitos legais podendo pedir os benefícios. Se concedidos, o estrangeiro será encaminhado à Polícia Federal para ser levado embora do País. ${ }^{357}$

vista do delito cometido (CF, artigo 5º, XLVIII). STF. Habeas Corpus 82959/SP - São Paulo. Relator: Ministro Marco Aurélio. Julgado em: 23/02/2006. Órgão Julgador: Tribunal Pleno, pp. 553554.

356 SouzA, Artur de Brito Gueiros. Presos estrangeiros no Brasil: aspectos jurídicos e criminológicos, pp. 206-210.

${ }^{357}$ O Juiz que condena o estrangeiro, a Polícia Federal ou o Ministério Público informam o Ministério da Justiça que o estrangeiro cometeu um crime. Motivos mais freqüentes de expulsão são os crimes relacionados a tráfico de entorpecentes, falsificação e uso de documento público, furto e roubo.Por despacho do Diretor do Departamento de Estrangeiros, é determinada a instauração de inquérito administrativo para fins de expulsão. Esse inquérito está regulamentado pelo artigo 103 e parágrafos do Decreto n. ${ }^{\circ} 86.175 / 81$, tratando-se de procedimento administrativo de colheita de informações que 
Conforme jurisprudência não rara, pedidos de livramento condicional ainda são indeferidos porque "esbarram na condição de estrangeiro", sob o fundamento de ser o benefício incabível aos condenados estrangeiros em situação administrativamente irregular, tendo em vista o risco de fuga e a impossibilidade do estrangeiro permanecer regularmente no território nacional e exercer atividade lícita e ainda, se contra eles já fora expedido decreto de expulsão. 358

O artigo 83, III do Código Penal condiciona o livramento condicional desde que "comprovado comportamento satisfatório durante a execução da pena, bom desempenho no trabalho que lhe foi atribuído e aptidão para prover à própria subsistência mediante trabalho honesto." Ocorre que o artigo 98, do Estatuto do Estrangeiro, Lei $\mathrm{n}^{\circ}$ 6.815, de 19 de agosto de 1980, proíbe ao estrangeiro com situação irregular o exercício de atividade honesta e remunerada, ao dispor que "ao estrangeiro que se encontra no Brasil ao amparo de visto de turista, de trânsito ou temporário de que trata o artigo 13, item IV, bem como aos dependentes de titulares de quaisquer vistos temporários é vedado o exercício de atividade remunerada. Ao titular de visto temporário de que trata o artigo 13, item VI, é vedado o exercício de atividade remunerada por fonte brasileira."

devem ser encaminhadas pela Polícia Federal com relatório conclusivo, ao Ministério da Justiça. Após recebimento do referido inquérito, estando devidamente instruído, é feita a análise de mérito objetivando verificar se o Expulsando não se encontra amparado pela legislação brasileira tendo se tornado inexpulsável (artigo 75 do Estatudo do Estrangeiro: quando o cônjuge for brasileiro; ou quando tiver filho brasileiro). Se for passível de expulsão, é encaminhado um parecer conclusivo ao Ministro da Justiça, a quem cabe decidir sobre a expulsão, por delegação do Presidente da República. Convém ressaltar que a Portaria expulsória é condicionada, via de regra, ao cumprimento total da pena ou à liberação do estrangeiro pelo Poder Judiciário. Para a expulsão ser efetivada, o estrangeiro tem que cumprir a pena ou ser beneficiado com o livramento condicional da pena e ser liberado pelo Juiz da Vara de Execuções Criminais. Nos casos de expulsão o Ministro assina uma Portaria Ministerial de Expulsão no uso da competência que lhe foi delegada pelo Presidente da República pelo artigo $1^{\circ}$ do Decreto n. ${ }^{\circ} 3.447$, de 05 de maio de 2000. O estrangeiro não pode mais voltar ao Brasil depois de expulso. É o crime previsto no artigo 338 do Código Penal. Quando o estrangeiro assina o termo de expulsão, toma ciência da existência desse embasamento legal. Ministério da Justiça. Estrangeiros.

Medidas Compulsórias. Extradição. Disponível online em: <http://portal.mj.gov.br/data/Pages/MJ0428DBCEITEMID332D78E06C8843B294375C9012D65C71 PTBRNN.htm> (acesso em 06/04/2011).

358 TRF-2 - Habeas Corpus - Processo: 2001.02.01.030900-7: Data Decisão: 13/11/2001: TRF20007940. A jurisprudência dos Tribunais Superiores se orienta no sentido de que, em se tratando, de estrangeiro cuja expulsão já tenha sido decretada não faz jus à progresso de regime de cumprimento de pena (STF-2 ${ }^{\mathrm{a}}$ Turma, Habeas Corpus 68.135/DF, Rel. Ministro Paulo Brossard, DJ 13/09/91; STF-RHC 64.643-3/SP, Rel. Ministro Aldir Passarinho, DJ 27/02/87; STJ- 5 ${ }^{\text {a }}$ Turma, HC 3596/SP, Rel. Ministro Assis Toledo, DJ 26/02/96; STJ-5 ${ }^{\text {a }}$ Turma, RHC 1.276/PR, Rel. Ministro Edson Vidigal, DJ 09/09/91, etc) -Tal entendimento baseia-se na probabilidade de frustração da própria ordem de expulsão do estrangeiro nocivo ao País, ou seja, da própria finalidade do instituto (Lei 6.815, artigo 67). Ordem denegada. 
Isso sem falar que o artigo 125, inciso VII prevê que é crime empregar ou manter a seu serviço estrangeiro em situação irregular ou impedido de exercer atividade remunerada. Por esses mesmos motivos também são negados a eles os benefícios da progressão e da substituição da pena privativa de liberdade por restritivas de direitos, sendo o risco o de "evasão do distrito da culpa". 359

O que se tem assistido, na verdade, é a perpetuação de jurisprudência anterior à Constituição de 1988, a qual não condiz com os objetivos, fundamentos ou princípios estabelecidos pela nova ordem constitucional. Nos Tribunais de Justiça, especialmente o de São Paulo - mais pesquisado haja vista a grande população carcerária estrangeira, e a existência de Presídio especial para abrigar os estrangeiros cumprindo pena no estado de São Paulo, a PENITEnciária CABo PM MARCElo PIRES DA SILVA $^{360}$ - os recursos que indeferem os benefícios como progressão do regime e livramento condicional, ainda se fundamentam na "condição de estrangeiro em situação irregular no País". Para ARTUR DE BRITO GUEIROS SOUZA ${ }^{361}$, essa jurisprudência apóia-se em quatro argumentos:

\footnotetext{
${ }^{359}$ Prisão preventiva. Cabível o decreto de prisão preventiva a réu processado por sonegação fiscal, diante do fato de ser o réu estrangeiro, podendo afastar-se do distrito da culpa e, assim, dificultar a instrução criminal e até mesmo impedir a aplicação da lei penal. (Habeas Corpus $N^{o} 692053820$, Câmara de Férias Criminal, Tribunal de Justiça do RS, Relator: João Andrades Carvalho, Julgado em 09/07/1992).

2. Agravo em Execução $n^{\circ}$ 99008071741/3. Comarca de São Paulo - (Execução $n^{\circ}$ 767.655) - Juízo de Origem Vara das Execuções Criminais - Oitava Câmara de Direito Criminal Agravante: Janet Perez Casas - Agravado o Ministério Público - Relatora: Ministra Maria Tereza do Amaral.

${ }^{360}$ As cadeias do país já abrigam quase meio milhão de presos; só em São Paulo são mais de 173 mil. O Brasil só perde para EUA e China em detentos. São 247 pessoas presas para cada 100 mil habitantes. Disponível online em: < http://www.fatoexpresso.com.br/2010/12/02/prisoes-brasil-temterceira-maior-populacao-carceraria-do-mundo/> (acesso em 15/02/2011) A capacidade carcerária do Presídio de Itaí - "Penitenciária CABo PM MARCElo Pires DA SiLVA" - é de 792, no entanto, na atualidade, abriga aproximadamente 1287 estrangeiros presos. Secretaria da Administração Carcerária. Disponível online em:<http://untreaty.un.org/cod/diplomaticconferences/consrelat1963/consrelat-1963.html> (acesso em 15/02/2011).

${ }^{361}$ SouzA, Artur de Brito Gueiros. O preso estrangeiro no Brasil: aspectos jurídicos e criminológicos, p. 206. Um exemplo de entendimento jurisprudencial do Supremo Tribunal Federal anterior à atual Constituição é de 1978: "Livramento condicional. Inadmissibilidade de sua concessão a estrangeiro cuja expulsão foi decretada, estando a efetivação desta providencia condicionada ao cumprimento das penas a que ele estiver sujeito no país. "Habeas corpus" indeferido." Habeas Corpus 56311/SP - São Paulo. Relator: Ministro Moreira Alves. Julgado em: 06/10/1978. Outro exemplo, agora sobre o risco de fuga, é o seguinte: "Habeas Corpus. Estrangeiro condenado. Expulsão decretada. Progressão ao regime semi-aberto. A progressão ao regime semi-aberto e incompatível com a situação do estrangeiro cujo cumprimento da ordem de expulsão esta aguardando o cumprimento de pena privativa de liberdade por crimes praticados no Brasil, sob pena de desnaturar a sua finalidade. "Habeas-corpus" conhecido, mas indeferido." STF. Habeas Corpus 68135/DF - Distrito Federal. Relator: Min. Paulo Brossard. Julgado em 20/08/1991. Órgão Julgador: Segunda Turma.
} 
"O primeiro, consiste na pendência de processo de expulsão ou mesmo de expulsão já decretada operando em desfavor do estrangeiro que cumpre pena. O segundo defende a eficácia da regra do artigo $1^{o}$, do Decreto $n^{o} 4.865 / 42$, que pró́be a concessão de sursis terceira razão para se vedar o deferimento de direitos prisionais ao estrangeiro é a desconfiança com relação àquele que sem maiores vínculos com a nossa sociedade, encontrar-se-ia propenso a empreender fuga, frustrando, assim, o cumprimento das condições judiciais e, mais especificamente, a sua posterior retirada administrativa do território nacional. $O$ último argumento reporta-se à proibição contida na legislação de estrangeiros, com relação à obtenção de emprego formal por parte do forasteiro em situação irregular (não podendo, legalmente, trabalhar no Brasil, não poderia cumprir, por exemplo, uma das condições ao livramento condicional ou ao regime prisional aberto)."

O Supremo Tribunal Federal consagra que o súdito estrangeiro, mesmo aquele sem domicílio no Brasil, tem direito a todas as prerrogativas básicas que lhe assegurem a preservação do "status libertatis" e a observância, pelo poder público, da cláusula constitucional do "due process". A condição jurídica de nãonacional do Brasil e a circunstância de o réu estrangeiro não possuir domicílio em nosso país não legitimam a adoção contra o estrangeiro, de qualquer tratamento arbitrário ou discriminatório. E ainda, impõe-se, ao Judiciário, o dever de assegurar ao réu estrangeiro sem domicílio no Brasil, os direitos básicos que resultam do postulado do devido processo legal, notadamente as prerrogativas inerentes à garantia da ampla defesa, contraditório, igualdade entre as partes perante o juiz natural e à garantia de imparcialidade do magistrado processante. ${ }^{362}$

A garantia de inviolabilidade dos direitos fundamentais da pessoa humana não comporta exceção baseada em qualificação subjetiva e circunstancial de nacionalidade. Com efeito, sob os princípios que regem a Constituição Federal de 1988, como o da individualização da pena ${ }^{363}$, se o estrangeiro cumpre com todos os

\footnotetext{
362 "Habeas Corpus - estrangeiro não domiciliado no Brasil - irrelevância - condição jurídica que não o desqualifica como sujeito de direitos e titular de garantias constitucionais e legais - plenitude de acesso, em conseqüência, aos instrumentos processuais de tutela da liberdade - necessidade de respeito, pelo poder público, às prerrogativas jurídicas que compõem o próprio estatuto constitucional do direito de defesa." STF. HC 94404/SP - São Paulo. Relator: Ministro Celso de Mello. Julgado em: 18/11/2008. Órgão Julgador: Segunda Turma.

${ }^{363}$ A Corte Interamericana de Direitos Humanos, na Opinião Consultiva n. ${ }^{\circ} 16$ de 1999, afirmou que é requisito indispensável para a própria individualização da pena a identificação do acusado, um dever que recai no Estado que o detém sob sua custódia. Essa identificação é essencial, por exemplo, para determinar a idade do sujeito privado de liberdade e assegurá-lo um tratamento adequado a suas circunstâncias. No cumprimento do dever de identificar o detido, o Estado utiliza mecanismos
} 
requisitos para a progressão de regime, não há por que obrigá-lo a cumprir a pena sob o regime integralmente fechado, com base em critério discriminatório que é condição de estrangeiro não residente. Até porque, a progressão de regime, bem como o livramento condicional são formas de cumprimento da pena. ${ }^{364}$

Em seu voto, a Ministra ELLEN GRACIE ressalta que, da leitura do artigo 98 do Estatuto do Estrangeiro, não se constata proibição alguma de trabalho remunerado ao condenado estrangeiro, porque sua situação não se subsume a nenhuma das hipóteses lá previstas, já que está no território brasileiro pela força inexorável de sentença penal condenatória, que impõe sua permanência aqui. E é esse mesmo título judicial que lhe impõe a obrigação de trabalhar como condição para progressão de regime. E sobre estar o estrangeiro com processo de expulsão pendente, trata-se de uma prerrogativa do Poder Executivo em decidir o momento em que a expulsão deva efetivar-se, por conveniência ou interesse nacional, independentemente da existência de processo ou condenação (artigo 67 do Estatuto do Estrangeiro). Ao optar pelo estrangeiro cumprir pena no Brasil, não pode subtrair do estrangeiro nenhum de seus direitos constitucionais, que incluem o da individualização da pena. A condição de estrangeiro não lhe tira o direito à progressão de regime, nos termos do artigo 112 da Lei de Execução Penal. ${ }^{365}$ Isso porque a República Federativa do Brasil tem como fundamento a dignidade da

estabelecidos em seu direito interno com este propósito e que necessariamente incluem os registros de controle migratório, no caso de estrangeiros. Opinião Consultiva Número 16 de $1^{\circ}$ de outubro de 1999, solicitada pelos Estados Unidos Mexicanos perante à Corte Interamericana de Direitos Humanos. $O$ direito de informação sobre a assistência consular no âmbito das garantias do Devido Processo Legal, $§ 94$.

364 "Pena - Regime de cumprimento - Progressão - razão de ser. A progressão no regime de cumprimento da pena, nas espécies fechado, semi-aberto e aberto, tem como razão maior a ressocialização do preso que, mais dia ou menos dia, voltará ao convívio social. Pena - Crimes Hediondos - Regime de cumprimento - progressão - óbice - artigo $2^{o}$, $\$ 1^{o}$, da Lei $n^{o} 8.072 / 90$ Inconstitucionalidade - Evolução jurisprudencial. Conflita com a garantia da individualização da pena - artigo $5^{\circ}$, inciso XLVI, da Constituição Federal - a imposição, mediante norma, do cumprimento da pena em regime integralmente fechado. Nova inteligência do princípio da individualização da pena, em evolução jurisprudencial, assentada a inconstitucionalidade do artigo $2^{o}$, \& $1^{o}$, da Lei $n^{o}$ 8.072/90. STF. Habeas Corpus 82959/SP - São Paulo. Relator: Ministro Marco Aurélio. Julgado: 23/02/2006. Órgão Julgador: Tribunal Pleno.

365 "Execução Penal. Pena privativa de liberdade. Progressão de regime. Admissibilidade. Condenação por tráfico de drogas. Estrangeira sem domicílio no país e objeto de processo de expulsão. Irrelevância. HC concedido. Voto vencido. O fato de o condenado por tráfico de droga ser estrangeiro, estar preso, não ter domicílio no país e ser objeto de processo de expulsão, não constitui óbice à progressão de regime de cumprimento da pena." STF. Habeas Corpus 97147/MT - Mato Grosso. Relatora: Ministra Ellen Gracie. Relator para Acórdão: Ministro Cezar Peluso. Julgado em: 04/08/2009. Órgão Julgador: Segunda Turma. 
pessoa humana, como objetivo fundamental a promoção do bem de todos, sem preconceitos de origem, raça, sexo, cor, idade e quaisquer outras formas de discriminação, e como princípio regente de suas relações internacionais a prevalência dos Direitos Humanos. (artigos $1^{\circ}$, inc. III, $3^{\circ}$, inc. IV, $4^{\circ}$, inc. II, da Carta Magna, respectivamente).

\section{A Ministra Maria Thereza de Assis Moura destaca que nem o} Código Penal, nem o Estatuto do Estrangeiro (Lei 6.815/80) e muito menos a Lei de Execuções Penais (Lei 7.210/84) fazem qualquer restrição aos direitos dos estrangeiros que cumprem pena no país, razão pela qual não há que se falar em desequiparação legal. O princípio da igualdade deve ser observado com o fim de assegurar ao estrangeiro uma forma digna de cumprimento de pena, assegurando-lhe todas as garantias, pois sua condição jurídica não o desqualifica como sujeito de direitos. ${ }^{366}$ Em outro julgado ${ }^{367}$, ela asseverou o seguinte:

366 "Processual Penal. Execução penal. Habeas Corpus. Estrangeiro não-residente no país. Progressão de regime prisional. Possibilidade. 1. Tanto a execução penal do nacional quanto a do estrangeiro submetem-se aos cânones constitucionais da isonomia e da individualização da pena. 2. Não se admite, após a nova ordem constitucional inaugurada em 1988, a remissão a julgados que se reportam a comandos com ela incompatíveis. 3. A disciplina do trabalho no Estatuto do Estrangeiro não se presta a afastar o co-respectivo direito-dever do condenado no seio da execução penal. Ordem concedida". STJ. Habeas Corpus 164744/SP. 2010/0042109-0. Relatora: Ministra Maria Thereza de Assis Moura. Órgão Julgador: T6 - Sexta Turma. Julgado em: 26/08/2008. Outros exemplos ilustradores da posição do STJ:

"Penal. Progressão ao regime semi-aberto. Estrangeiro. Expulsão decretada. A jurisprudência do Supremo Tribunal Federal e desta Corte é no sentido de ser a progressão ao regime semi-aberto incompatível com a situação do estrangeiro cujo cumprimento da ordem de expulsão esteja aguardando o termino da pena privativa de liberdade por crimes praticados no Brasil. Reservas feitas pelo Ministro-Relator quanto a esse entendimento, tendo em vista que a condição de "estrangeiro", erigida em critério discriminatório, não encontra amparo em norma legal expressa e a finalidade que se quer atribuir a essa discriminação não tem justificativa razoável, visto que o regime semi-aberto e, na verdade, regime "semifechado", cumprido em penitenciaria agrícola, industrial ou estabelecimento similar (artigo 35, $\$ 1^{\circ}, C P$ ), oferecendo garantias contra fugas, permitindo, pois, a execução da ordem de expulsão. Hipótese, porém, em que não se dispõe de elementos nos autos para a decisão quanto ao mérito do pedido, que dependeria de exame de prova, incabivel na via sumaríssima do writ. Habeas Corpus indeferido." Habeas Corpus 3596/SP. Habeas Corpus 1995/0031646-3. Ministro Assis Toledo. T5 - Quinta Turma. Julgado em: 04/10/1995.

"Criminal. Falsidade Ideológica. Pena inferior a quatro anos. Réus primários e de bons antecedentes. Fixação de regime semi-aberto. Possibilidade. Estrangeiros em situação irregular no país. não comprovação de residência fixa ou exercício de atividade lícita. Questões controvertidas. Impropriedade do writ. Ordem denegada. I. Hipótese que cuida de réus estrangeiros, em situação irregular no país, condenados por falsidade ideológica, ao cumprimento de pena em regime semiaberto.

II. A determinação de pena inferior a 04 (quatro) anos, a condenado não reincidente, não implica, automaticamente, na fixação do regime aberto. III. A escolha do regime de cumprimento da pena é ato discricionário do Juiz que, após a análise das circunstâncias concretas de cada caso, poderá optar pelo regime mais gravoso, desde que o faça com adequada e suficiente fundamentação. III. Não se encontrando a questão da existência de residência fixa e exercício de ocupação lícita livre de 
"Ao estrangeiro preso e condenado não se deve aplicar, isolada e descontextualizadamente, o Estatuto do Estrangeiro. É imperioso, no caso, atender-se às disposições da Lei de Execuções Penais, por ser, na hipótese, o diploma de regência da matéria em questão. Assim, nos termos do artigo 31 e 41, inciso II, da Lei 7.210/84, independentemente de ser nacional ou estrangeiro, o preso condenado tem o dever e o direito de trabalhar. Cumpre, dessa forma, fomentar o trabalho do preso estrangeiro, independentemente do regime de cumprimento de pena, bem como durante o livramento condicional. Reitere-se que sua permanência no país decorre da submissão ao ius punitionis, o qual é conformado pela sujeição do condenado ao trabalho."

Referente ao direito de informação sobre a assistência consular, a única jurisprudência específica que relaciona-se ao tema objeto do presente trabalho pertence ao Superior Tribunal de Justiça. Na decisão, a nulidade não foi reconhecida, porque não ficou demonstrado que esse direito não foi negado ao estrangeiro ou dispensado por ele, para configurar uma eventual nulidade. Em seu voto, o Ministro Relator, observou assim: "Inviável se mostra o conhecimento da questão relativa à assistência consular para o réu estrangeiro, uma vez que não foi demonstrado que esse direito lhe tenha sido negado. Ao contrário disso, extrai-se dos autos que a Polícia Federal, mediante oficio, comunicou o Cônsul do Peru em Rio Branco/AC sobre a prisão em flagrante do seu compatriota., ${ }^{, 368}$

Ocorre que é difícil para o estrangeiro que enfrenta uma acusação criminal conhecer, naquela situação, a importância que para ele representa receber a assistencia por parte dos funcionários consulares de seu país de origem. Discutiu-se anteriormente que na situação de privação de liberdade, o estrangeiro encontra-se geralmente em situação de vulnerabilidade por diversos motivos: desconhecimento da língua, do procedimento criminal ao qual se encontra submetido, dificuldade para

controvérsias, dependendo de incursão na seara fático-probatória dos autos, evidenciada está a impropriedade do writ para o seu exame. IV. Ordem denegada. Habeas Corpus 25298/PR 2002/0147904-2. Ministro Gilson Dipp. T5 - Quinta Turma. Julgado em: 25/05/2004.

Artigo 114 da LEP: "Somente poderá ingressar no regime aberto o condenado que: I - estiver trabalhando ou comprovar a possibilidade de fazê-lo imediatamente (...); Artigo 115 da LEP: “O Juiz poderá estabelecer condições especiais para a concessão de regime aberto, sem prejuízo das seguintes condições gerais e obrigatórias: I - permanecer no local que for designado, durante o repouso e nos dias de folga; II - sair para o trabalho e retornar, nos horários fixados; III - não se ausentar da cidade onde reside, sem autorização judicial; IV - comparecer a Juízo, para informar e justificar as suas atividades, quando for determinado.

${ }^{367}$ STJ. Habeas Corpus no 103.373-SP (2008/0069202-5). Relatora: Ministra Maria Thereza de Assis Moura. Órgão Julgador: T6 - Sexta Turma. Julgado em: 26/08/2008.

${ }^{368}$ STJ. Habeas Corpus 65835/AC - 2006/0194006-7 - Relator: Ministro Arnaldo Esteves Lima- T5 Quinta Turma - julgado em 21/08/2008. 
levantar provas atenuantes ou absolvitórias, testemunhas favoráveis, ou contato com a família, entre outros - não conhece o direito que tem de comunicar-se com seu Consulado, tampouco sabe que pode negar esse direito, nos termos do artigo 36 da Convenção de Viena de 1963.

O Estado não pode deixar de resguardar direitos inerentes à dignidade humana a ponto de discriminar os estrangeiros não residentes no país, devendo o tratamento entre brasileiros e estrangeiros ser isonômico inclusive quanto ao estatuto normativo da execução da pena, por não haver motivos jurídicos idôneos que determinem vedação geral de progressão de regime para estrangeiros por não poderem preencher os requisitos dispostos notadamente nos artigos 114, I e 115 da Lei de Execução Penal n. ${ }^{\circ}$ 7.210/1984 para a progressão do regime. É mais importante que o estrangeiro esteja apto para trabalhar, do que comprovar a possibilidade imediata de trabalhar. 


\section{Capítulo 9}

\section{A ASSISTÊNCIA CONSUlar COMO COMPONENTE DO DIREITO DE DEFESA: A AUSÊNCIA OU DEFICIÊNCIA DA GARANTIA DESSE DIREITO COMO CAUSA DE NULIDADE NO PROCESSO PENAL}

Nesta abordagem final do tema objeto da pesquisa busca-se identificar a incorporação do direito de informação sobre assistência consular para preso estrangeiro no direito processual penal, como importante mecanismo para efetivação do exercício da ampla defesa, podendo sua ausência ou deficiência de efetivação resultar, em cada caso concreto, em prejuízo à auto defesa e ampla defesa, desde que efetivamente demonstrado pela parte (conforme mandam os artigos 563 e 566 do Código de Processo Penal, e Súmula 523 do Supremo Tribunal Federal ${ }^{369}$ ), acarretando em nulidade processual absoluta (pás de nullité sans grief - não há nulidade sem prejuízo). A impossibilidade de realização ampla do contraditório e do direito de defesa do acusado, em todos os meios a ela inerentes, é causa inconteste de nulidade absoluta.

Dito isso, a partir do estudo panorâmico e contextualizador, anteriormente realizado, a problemática consiste em considerar o direito de assistência consular para preso estrangeiro sob a ótica da interpretação contemporânea do Direito Internacional Público e ao abrigo do inciso LXIII e $\S 2^{\circ}$, ambos do artigo $5^{\circ}$ da Constituição Federal de 1988, como sendo um dos componentes das garantias do devido processo legal, no sentido da efetivação do

\footnotetext{
${ }^{369}$ Artigo 563.Nenhum ato será declarado nulo, se da nulidade não resultar prejuízo para a acusação ou para a defesa. Artigo565.Nenhuma das partes poderá argüir nulidade a que haja dado causa, ou para que tenha concorrido, ou referente a formalidade cuja observância só à parte contrária interesse.
} 
direito à ampla defesa, no caso de estrangeiros submetidos à jurisdição criminal brasileira.

\section{A comunidade internacional manifestou sua preocupação com a}

integridade das garantias processuais básicas reconhecidas às pessoas meramente acusadas de práticas delituosas em sede de proteção aos direitos humanos, seja em âmbito regional, aplicável o sistema interamericano, como o artigo $8^{\circ}$ da Convenção Americana sobre Direitos Humanos ${ }^{370}$; seja em âmbito global, como o artigo 14 do Pacto Internacional sobre Direitos Civis e Políticos ${ }^{371}$, celebrado sob a égide da

370 Aderida pelo Brasil em 25 de setembro de 1992, foi incorporada ao nosso sistema de direito positivo interno pelo Decreto ${ }^{\circ}$ 678, de 06 de novembro de 1992. O tratado dispõe expressamente em seu preâmbulo que "os direitos essenciais do homem não derivam do fato de ser ele nacional de determinado Estado, mas sim do fato de ter como fundamento os atributos da pessoa humana, razão por que justificam uma proteção Internacional, de natureza convencional, coadjuvante ou complementar da que oferece o direito interno dos Estados americanos." Artigo 80: "Garantias Judiciais 1. Toda pessoa tem direito a ser ouvida, com as devidas garantias e dentro de um prazo razoável, por um juiz ou tribunal competente, independente e imparcial, estabelecido anteriormente por lei, na apuração de qualquer acusação penal formulada contra ela, ou para que se determinem seus direitos ou obrigações de natureza civil, trabalhista, fiscal ou de qualquer outra natureza. 2. Toda pessoa acusada de delito tem direito a que se presuma sua inocência enquanto não se comprove legalmente sua culpa. Durante o processo, toda pessoa tem direito, em plena igualdade, às seguintes garantias mínimas:a) direito do acusado de ser assistido gratuitamente por tradutor ou intérprete, se não compreender ou não falar o idioma do juízo ou tribunal;b) comunicação prévia e pormenorizada ao acusado da acusação formulada;c) concessão ao acusado do tempo e dos meios adequados para a preparação de sua defesa;d) direito do acusado de defender-se pessoalmente ou de ser assistido por um defensor de sua escolha e de comunicar-se, livremente e em particular, com seu defensor;e) direito irrenunciável de ser assistido por um defensor proporcionado pelo Estado, remunerado ou não, segundo a legislação interna, se o acusado não se defender ele próprio nem nomear defensor dentro do prazo estabelecido pela lei;f) direito da defesa de inquirir as testemunhas presentes no tribunal e de obter o comparecimento, como testemunhas ou peritos, de outras pessoas que possam lançar luz sobre os fatos; $g$ ) direito de não ser obrigado a depor contra si mesma, nem a declarar-se culpada; $e$ h) direito de recorrer da sentença para juiz ou tribunal superior. 3. A confissão do acusado só é válida se feita sem coação de nenhuma natureza. 4. O acusado absolvido por sentença passada em julgado não poderá ser submetido a novo processo pelos mesmos fatos. 5. O processo penal deve ser público, salvo no que for necessário para preservar os interesses da justiça."

371 "Todas as pessoas são iguais perante os tribunais e as cortes de justiça. Toda pessoa terá o direito de ser ouvida publicamente e com devidas garantias por um tribunal competente, independente e imparcial, estabelecido por lei, na apuração de qualquer acusação de caráter penal formulada contra ela ou na determinação de seus direitos e obrigações de caráter civil. A imprensa e o público poderão ser excluídos de parte da totalidade de um julgamento, quer por motivo de moral pública, de ordem pública ou de segurança nacional em uma sociedade democrática, quer quando o interesse da vida privada das Partes o exija, que na medida em que isso seja estritamente necessário na opinião da justiça, em circunstâncias específicas, nas quais a publicidade venha a prejudicar os interesses da justiça; entretanto, qualquer sentença proferida em matéria penal ou civil deverá torna-se pública, a menos que o interesse de menores exija procedimento oposto, ou processo diga respeito à controvérsia matrimoniais ou à tutela de menores. 2. Toda pessoa acusada de um delito terá direito a que se presuma sua inocência enquanto não for legalmente comprovada sua culpa. 3. Toda pessoa acusada de um delito terá direito, em plena igualmente, a, pelo menos, as seguintes garantias: a) De ser informado, sem demora, numa língua que compreenda e de forma minuciosa, da natureza e dos motivos da acusação contra ela formulada; b) De dispor do tempo e dos meios necessários à preparação de sua defesa e a comunicar-se com defensor de sua escolha;c) De ser julgado sem dilações indevidas;d) De estar presente no julgamento e de defender-se pessoalmente ou por intermédio de defensor de sua escolha; de ser informado, caso não tenha defensor, do direito que the 
Organização das Nações Unidas. Ambos os instrumentos proclamam a essencialidade do direito de defesa, como um complexo de princípios e de normas que amparam qualquer acusado em sede de persecução criminal, mesmo que se trate de réu estrangeiro, sem domicílio em território nacional, aí processado por suposta prática delituosa contra ele atribuído, além das demais prerrogativas que derivam dos dispositivos que versam sobre as garantias do devido processo legal. ${ }^{372}$ Os

assiste de tê-lo e, sempre que o interesse da justiça assim exija, de ter um defensor designado exoffício gratuitamente, se não tiver meios para remunerá-lo;e) De interrogar ou fazer interrogar as testemunhas de acusação e de obter o comparecimento e o interrogatório das testemunhas de defesa nas mesmas condições de que dispõem as de acusação;f) De ser assistida gratuitamente por um intérprete, caso não compreenda ou não fale a língua empregada durante o julgamento;g) De não ser obrigada a depor contra si mesma, nem a confessar-se culpada. 4. O processo aplicável a jovens que não sejam maiores nos termos da legislação penal em conta a idade dos menos e a importância de promover sua reintegração social. 5. Toda pessoa declarada culpada por um delito terá direito de recorrer da sentença condenatória e da pena a uma instância superior, em conformidade com a lei. 6. Se uma sentença condenatória passada em julgado for posteriormente anulada ou se um indulto for concedido, pela ocorrência ou descoberta de fatos novos que provem cabalmente a existência de erro judicial, a pessoa que sofreu a pena decorrente desse condenação deverá ser indenizada, de acordo com a lei, a menos que fique provado que se lhe pode imputar, total ou parcialmente, a não revelação dos fatos desconhecidos em tempo útil. 7. Ninguém poderá ser processado ou punido por um delito pelo qual já foi absorvido ou condenado por sentença passada em julgado, em conformidade com a lei e os procedimentos penais de cada país."

${ }^{372}$ HC 93503/SP - São Paulo. Relator: Ministro Celso de Mello Julgamento: 02/06/2009. Órgão Julgador: Segunda Turma. "Habeas Corpus" - Instrução Processual - réu preso - pretendido comparecimento à audiência penal em que inquiridas testemunhas da acusação - réu requisitado, mas não apresentado ao juízo deprecado - indeferimento do pedido de adiamento da audiência constrangimento ilegal caracterizado - a garantia constitucional da plenitude de defesa: uma das projeções concretizadoras da cláusula do "due process of law" - caráter global e abrangente da função defensiva: defesa técnica e autodefesa (direito de audiência e direito de presença) - pacto internacional sobre direitos civis e políticos/ONU (Artigo 14, n. 3, "d") E Convenção Americana de Direitos Humanos/OEA (artigo $8^{\circ}, \S 2^{\circ}$, "d" e "f") - dever do Estado de assegurar, ao réu preso, o exercício dessa prerrogativa essencial, especialmente a de comparecer à audiência de inquirição das testemunhas, ainda mais quando arroladas pelo Ministério Público - razões de conveniência administrativa ou governamental não podem legitimar o desrespeito nem comprometer a eficácia e a observância dessa franquia constitucional - nulidade processual absoluta - pedido deferido. - $O$ acusado, embora preso, tem o direito de comparecer, de assistir e de presenciar, sob pena de nulidade absoluta, os atos processuais, notadamente aqueles que se produzem na fase de instrução do processo penal, que se realiza, sempre, sob a égide do contraditório. São irrelevantes, para esse efeito, as alegações do Poder Público concernentes à dificuldade ou inconveniência de proceder à remoção de acusados presos a outros pontos da própria comarca, do Estado ou do País, eis que razões de mera conveniência administrativa não têm - nem podem ter - precedência sobre as inafastáveis exigências de cumprimento e respeito ao que determina a Constituição. Doutrina. Jurisprudência (HC 86.634/RJ, Rel. Min. Celso de Mello, v.g.). - O direito de audiência, de um lado, e o direito de presença do réu, de outro, esteja ele preso ou não, traduzem prerrogativas jurídicas essenciais que derivam da garantia constitucional do "due process of law" e que asseguram, por isso mesmo, ao acusado, o direito de comparecer aos atos processuais a serem realizados perante o juízo processante, ainda que situado este em local diverso daquele em que esteja custodiado o réu. Pacto Internacional sobre Direitos Civis e Políticos/ONU (Artigo 14, n. 3, "d") e Convenção Americana de Direitos Humanos/OEA (Artigo 8", $\S 2^{\circ}$, "d" e "f"). Precedente: HC 86.634/RJ, Rel. Min. CELSO DE MELLO. - Essa prerrogativa processual reveste-se de caráter fundamental, pois compõe o próprio estatuto constitucional do direito de defesa, enquanto complexo de princípios e de normas que amparam qualquer acusado em sede de persecução criminal, mesmo que se trate de réu processado por suposta prática de crimes hediondos ou de delitos a estes equiparados. Precedentes." 
professores Ada Pellegrini Grinover, Antonio Magalhaes e Antonio SCARANCE $^{373}$ consideram serem normas de garantia com nível constitucional as de preceito processual encontradas na Convenção Americana sobre Direitos Humanos, integrada ao nosso ordenamento jurídico pelo Decreto n. $^{\circ} 678$, de 06 de novembro de 1992, e que passaram a integrar o sistema constitucional interno, tendo como fundamento de validade o artigo $5^{\circ}, \S 2^{\circ}$, da Constituição brasileira.

O Supremo Tribunal Federal tem como fundamento o $\S 2^{\circ}$ do artigo $5^{\circ}$ da Constituição para considerar a supralegalidade dos tratados internacionais de direitos humanos, o que autoriza afastar regra ordinária brasileira contrária. Esses tratados não são considerados normas constitucionais porque faltaria o rito exigido pelo $\S 3^{\circ}$ do artigo $5^{\circ}$. No entanto, o desafio proposto é acompanhar a interpretação conferida pela Corte Interamericana de Direitos Humanos, que considerou o direito de informação sobre assistência consular para preso estrangeiro como sendo um dos componentes das garantias do devido processo legal, não seria esse um direito protegido sob o fundamento o $\S 2^{\circ}$ do artigo $5^{\circ}$ da Constituição? Mas o que são "direitos e garantias"?

JosÉ AfONSO DA SILVA ressalta, em suma, que os direitos são bens e vantagens conferidos pela norma, enquanto as garantias são meios destinados a fazer valer esses direitos, isto é, são instrumentos que asseguram o exercício e gozo daqueles bens e vantagens. Em conjunto, as garantias constitucionais referem-se a imposições, positivas ou negativas, especialmente aos órgãos do Poder Público, limitativas de sua conduta, para assegurar a observância ou, caso contrário, a reintegração do direito violado. As garantias penais que se acham inscritas nos incisos XXXVII a LXVII do artigo $5^{\circ}$ da Constituição de 1988, por exemplo, são um meio de assegurar o direito de defesa. ${ }^{374}$ São normas que representam os direitos fundamentais do ser humano contra o poder intervencionista do Estado. SCARANCE ${ }^{375}$

\footnotetext{
${ }^{373}$ Grinover, Ada Pellegrini; Gomes FILHO, Antonio Magalhães; e FERnANDES, Antonio Scarance. As nulidades no Processo Penal, pp. 21-23.

${ }^{374}$ Silva, José Afonso da. Curso de Direito Constitucional Positivo, pp. 412 e ss.

375 Ele cita a Declaração Universal dos Direitos do Homem de 1948; a Convenção Européia para a Salvaguarda dos Direitos do Homem e das Liberdades Fundamentais de 1948; o Pacto Internacional dos Direitos Civis e Políticos de 1966; a Convenção Americana dos Direitos Humanos de 19 (Pacto de San José). Ele cita outros tratados que também visam à proteção dos direitos e garantias fundamentais do homem, como a Convenção contra a Tortura e outros Tratamentos ou Penas Cruéis,
} 
bem chama atenção para os tratados internacionais que passaram a ser firmado após a $2^{a}$ Guerra Mundial, o que ele chama de "declarações conjuntas, plenas de normas garantidoras, visando justamente a que seus signatários assumissem o compromisso de, em seus territórios, respeitarem os direitos básicos do indivíduo". São preceitos maiores, relativos à observância dos direitos fundamentais e das normas de ordem pública.

O princípio da proteção judiciária (artigo $5^{\circ}, \mathrm{XXXV}$, da Constituição de 1988), também conhecido como princípio da inafastabilidade do controle judicial, constitui a principal garantia dos direitos subjetivos. Fundamenta-se no princípio da separação de poderes, a garantia das garantias constitucionais, ao dispor que "a lei não excluirá da apreciação do Poder Judiciário lesão ou ameaça a direito”. Daí a Constituição elevar a nível constitucional uma infinidade de garantias, entre eles o direito de ação e o direito de defesa, e ainda garantir conteúdo a esses direitos, porque "não se limita a permitir o acesso aos tribunais, mas assegura, também, ao longo de todo iter procedimental, aquele conjunto de garantias constitucionais que, de um lado tutelam as partes quanto ao exercício de suas faculdades e poderes processuais e, do outro, são indispensáveis ao correto exercício da jurisdição: tratase das garantias do devido processo legal". 376

A idéia exclusivamente individualista das garantias constitucionaisprocessuais, de direitos subjetivos das partes, passou a enfocar na qualidade do próprio processo: um complexo de princípios e de normas que amparam qualquer acusado em sede de persecução criminal, mesmo que se trate de réu estrangeiro, sem domicílio em território brasileiro, aqui processado por suposta prática de delitos a ele atribuída.

E quando se fala em processo, alude-se a formas instrumentais adequadas para que a prestação jurisdicional, quando exercida pelo Estado, garanta, a

Desumanos ou Degradantes da Convenção sobre a Eliminação de todas as Formas de Discriminação contra a Mulher; a Convenção sobre a Eliminação de todas as Formas de Discriminação Racial; a Convenção sobre os Direitos da Criança. Fernandes, Antonio Scarance. Processo Penal Constitucional, p. 17.

376 GrinOver, Ada Pellegrini; GOMES FILHO, Antonio Magalhães; e FERNANDES, Antonio Scarance. As nulidades no Processo Penal, p. 69. 
cada um, o que é seu, conforme os imperativos da ordem jurídica. Isso compreende a garantia do contraditório, a plenitude do direito de defesa, a isonomia processual e a bilateralidade dos atos e procedimentos. ${ }^{377}$

Alguns elementos são essenciais para caracterizar um processo como imparcial, justo e legal. Legitimam a atividade jurisdicional e a ordem constitucional, e garantem o direito de toda sociedade para uma resposta jurisdicional imparcial, legal e justa. Destacam-se, dentre eles, os seguintes: 1) direito ao processo (garantia de acesso ao Poder Judiciário); 2) direito à citação e ao conhecimento prévio do teor da acusação; 3) direito a um julgamento público e célere, sem dilações indevidas; 4) direito ao contraditório e à plenitude de defesa (direito à autodefesa e à defesa técnica); 5) direito de não ser processado e julgado com base em lei "ex post facto"; 6) direito à igualdade entre as partes; 7) direito de não ser processado com fundamento em provas revestidas de ilicitude; 8) direito ao benefício da gratuidade; 9) direito à observância do princípio do juiz natural; 10) direito ao silêncio (privilégio contra a auto-incriminação); 11) direito à prova; e 12) direito de presença e de "participação ativa" nos atos de interrogatório judicial dos demais litisconsortes penais passivos, quando existentes. ${ }^{378}$

\footnotetext{
${ }^{377}$ SILVA, José Afonso da. Curso de Direito Constitucional Positivo, pp. 431 e 432.

378،“....) O súdito estrangeiro, mesmo aquele sem domicílio no Brasil, tem direito a todas as prerrogativas básicas que lhe assegurem a preservação do "status libertatis" e a observância, pelo poder público, da cláusula constitucional do "due process".O súdito estrangeiro, mesmo o não domiciliado no Brasil, tem plena legitimidade para impetrar o remédio constitucional do "habeas corpus", em ordem a tornar efetivo, nas hipóteses de persecução penal, o direito subjetivo, de que também é titular, à observância e ao integral respeito, por parte do Estado, das prerrogativas que compõem e dão significado à cláusula do devido processo legal. A condição jurídica de nãonacional do Brasil e a circunstância de o réu estrangeiro não possuir domicilio em nosso país não legitimam a adoção, contra tal acusado, de qualquer tratamento arbitrário ou discriminatório. Precedentes. - Impõe-se, ao Judiciário, o dever de assegurar, mesmo ao réu estrangeiro sem domicílio no Brasil, os direitos básicos que resultam do postulado do devido processo legal, notadamente as prerrogativas inerentes à garantia da ampla defesa, à garantia do contraditório, à igualdade entre as partes perante o juiz natural e à garantia de imparcialidade do magistrado processante. A essencialidade do postulado do devido processo legal, que se qualifica como requisito legitimador da própria "persecutio criminis". O exame da cláusula referente ao "due process of law" permite nela identificar alguns elementos essenciais à sua configuração como expressiva garantia de ordem constitucional, destacando-se, dentre eles, por sua inquestionável importância, as seguintes prerrogativas: (a) direito ao processo (garantia de acesso ao Poder Judiciário); (b) direito à citação e ao conhecimento prévio do teor da acusação; (c) direito a um julgamento público e célere, sem dilaçães indevidas; (d) direito ao contraditório e à plenitude de defesa (direito à autodefesa e à defesa técnica); (e) direito de não ser processado e julgado com base em leis "ex post facto"; (f) direito à igualdade entre as partes; $(g)$ direito de não ser processado com fundamento em provas revestidas de ilicitude; (h) direito ao benefício da gratuidade; (i) direito à observância do princípio do juiz natural; (j) direito ao silêncio (privilégio contra a auto-incriminação); (l) direito à prova; $e$ (m) direito de presença e de "participação ativa" nos atos de interrogatório judicial dos demais
} 
$\mathrm{O}$ artigo $5^{\circ}, \mathrm{XXXV}$, da Constituição consagra o direito de invocar a atividade jurisdicional como direito público subjetivo,tanto o direito de ação, como também direito daquele contra quem se propõe a ação. É assim que a Carta Maior assegura aos litigantes e acusados em geral o contraditório e a ampla defesa, com todos os meios e recursos inerentes. $\mathrm{O}$ direito de defesa é expressamente garantido em seu artigo $5^{\circ}$, inciso LV, que assegura aos litigantes, em processo judicial ou administrativo, e aos acusados em geral o contraditório e a ampla defesa, com os meios e recursos a ela inerentes. ${ }^{379}$ É do contraditório que se manifesta e garante-se o exercício de defesa que, por sua vez, como inerente ao direito de ação, garante o contraditório. É assim que ambos são indissoluvelmente ligados e interagem. ${ }^{380}$

Somando-se ainda o princípio da isonomia, conclui-se pelo direito à ampla defesa. O réu de qualquer ação penal proposta tem, igualmente, a possibilidade de defender-se, ou não, quando arcará com a sua omissão. O acusado encontra-se em posição menos vantajosa que o autor, porque fica circunscrito e obrigado a partir da escolha do autor, que pode escolher apresentar a ação, e o melhor momento para isso. É por esse motivo que, na visão de ANDRÉ RAMOS TAVARES, o direito de defesa é "o poder jurídico de pedir restituição da liberdade ameaçada pela ação". É um direito que não se extingue na apresentação da peça processual inicial - mas que se estende por todo o processo, igualmente para ambas as partes envolvidas. ${ }^{381}$

litisconsortes penais passivos, quando existentes. O direito do réu à observância, pelo Estado, da garantia pertinente ao "due process of law", além de traduzir expressão concreta do direito de defesa, também encontra suporte legitimador em convenções internacionais que proclamam a essencialidade dessa franquia processual, que compõe o próprio estatuto constitucional do direito de defesa, enquanto complexo de princípios e de normas que amparam qualquer acusado em sede de persecução criminal, mesmo que se trate de réu estrangeiro, sem domicílio em território brasileiro, aqui processado por suposta prática de delitos a ele atribuídos. STF. Habeas Corpus 94016/SP- São Paulo. Relator: Ministro Celso de Mello. Julgado em 16/09/2008. Órgão Julgador: Segunda Turma. ${ }^{379}$ Esta cláusula está presente nas Constituições anteriores, desde o Império: 1824, artigo 179, VIII; 1891, artigo 72, §16; 1934, artigo 113, n. 24; 1937, artigo 122, n. 11, segunda parte; 1946, artigo 141, $\S 25 ; 1967$, artigo 150, §15, e, com a Emenda de 1969, artigo 153, §15. SCARANCE explica que ora veio ligada à nota de culpa (1824, 1891, 1937 e 1946); ora esteve relacionada com a instrução criminal (1937, 1946). Isso significava que a garantia ao direito de defesa se aplicava apenas ao processo penal. O novo texto a estende a qualquer processo judicial ou administrativo. FERNANDES, Antonio Scarance. Processo Penal Constitucional, p. 289.

380 Grinover, Ada Pellegrini; GOMES FILHO, Antonio Magalhães; e FERNANDES, Antonio Scarance. As nulidades no Processo Penal, p. 69.

${ }^{381}$ TaVAres, André Ramos. Curso de Direito Constitucional, PP. 674 e 675. 
Para ANTONIO SCARANCE FERNANDES ${ }^{382}$, a defesa "é o direito que tem o indivíduo de reagir à ação contra si proposta, a fim de perseguir decisão favorável $e$, assim, preservar direitos substanciais questionados no processo". O titular do direito de defesa, no processo penal, pretende evitar a condenação e imposição da pena, que pode restringir a liberdade. Por isso que a defesa é necessária e indeclinável. E mesemo que o acusado não deseje se defender, impõe-se que alguém o faça para garantir a paridade de armas e o equilíbrio no processo. Exige-se a defesa substancial, isto é, a efetiva reação à acusação. E essa visão de defesa como direito incontestável, amplia-se quando a perspectiva é constitucional, revelando-se assim como garantia da própria sociedade, uma vez que é essencial ao Estado Democrático de Direito, ao qual só interessa a sentença justa, em consonância com as garantias do devido processo legal. De um lado, é uma garantia do acusado; de outro, é uma garantia do justo processo. Daí, em última análise, legitima a própria jurisdição, como garantia necessária da pessoa acusada e da própria sociedade, para legitimar o exercício da função jurisdicional no Estado de Direito.

A garantia constitucional à ampla defesa desdobra-se em meios a ela inerentes, tais quais: a) ter conhecimento claro do teor da acusação; b) poder apresentar alegações contra a acusação; c) poder acompanhar a prova produzida e fazer a contraprova; d) ter defesa técnica por advogado, cuja função é, inclusive, essencial à administração da justiça ${ }^{383}$; e e) poder recorrer da decisão desfavorável. $\mathrm{O}$ contraditório atua na efetivação da ampla defesa, como um meio, um instrumento técnico, no ato de contrariar a acusação; no de requerer a produção de provas pertinentemente obrigatórias; ao acompanhar a produção de provas e, no caso de testemunhas, preparando as perguntas cabíveis; além disso, a defesa deve falar sempre depois da acusação, manifestar-se em todos os atos e termos processuais aos quais devem estar presentes e recorrer sempre que irresignado.

ANTONIO SCARANCE ${ }^{384}$ explica que o processo penal reflete a busca do equilíbrio entre o assegurar ao Estado meios para exercer, com eficácia, o seu poder

\footnotetext{
${ }^{382}$ FERNANDES, Antonio Scarance. A Reação Defensiva à Imputação, pp.25 e 26.

383 Artigo 133 da Constituição: “O advogado é indispensável à administração da justiça, sendo inviolável por seus atos e manifestações no exercício da profissão, nos limites da lei”.

${ }^{384}$ FernANDES, Antonio Scarance. A Reação Defensiva à Imputação, pp. 20-21.
} 
punitivo, e o de garantir a todo indivíduo sujeito a um procedimento criminal o direito de se defender antes de ser julgado. O ideal, ainda que difícil de ser alcançado, para se configurar um Estado Democrático de Direito, é um regime processual e constitucional que conjugue eficiência (para o Estado punir) com pleno garantismo (garantias mínimas do justo processo do justo processo, com oportunidade de ampla reação do acusado à imputação). Assim, além do sistema acusatório bem definido, é preciso que a defesa esteja acobertada pelas garantias fundamentais do devido processo legal, com poderes amplos para reagir à acusação, em posição equilibrada. Para o jurista ${ }^{385}$, o direito de defesa está entre os institutos fundamentais do direito processual. $\mathrm{O}$ processo não se efetiva sem o resguardo às garantias essenciais do devido processo legal e, entre elas, as garantias constitucionais da defesa e do contraditório - exige-se a prévia apuração da culpa em processo jurisdicional, no qual deve ser assegurado ao réu a mais ampla oportunidade de reagir à acusação.

No processo penal brasileiro, a defesa desdobra-se em defesa técnica e autodefesa. A primeira é indisponível, porque condiciona a paridade das armas, imprescindível para concreta atuação do contraditório e à imparcialidade do Juiz, além de ser uma garantia do acusado. $\mathrm{O}$ acusado também tem o direito de escolher o advogado de sua confiança, e constitui nulidade absoluta e ofensa grave aos princípios do devido processo legal e da ampla defesa a nomeação de defensor dativo sem a intimação do réu para constituir novo defensor de sua confiança, em virtude da renúncia de seu advogado. Crucial também para a paridade de armas o efetivo contato e diálogo entre o acusado e seu defensor também na fase inquisitorial da investigação, em que a Defesa não é considerada imprescindível (exceto no caso do preso em flagrante, pelo artigo $5^{\circ}$, LXIII, Constituição de 1988). ${ }^{386}$

\footnotetext{
${ }^{385}$ FERNANDES, Antonio Scarance. A Reação Defensiva à Imputação, pp. 24 e 25.

${ }^{386}$ Por isso que a Constituição considera o advogado indispensável à administração da Justiça (artigo 133) e estrutura as Defensorias Públicas (artigo 134). A Lei 11.449 de 2007 deu nova redação ao artigo 306 do CPP, incluindo um $\S$ em que estabelece que o auto de prisão em flagrante será encaminhado em 24 horas ao Juiz competente, com cópia à Defensoria Pública, no caso de o autuado não informar o nome de seu advogado. GRINOVER, Ada Pellegrini; GOMES FILHO, Antonio Magalhães; e Fernandes, Antonio Scarance. As nulidades no Processo Penal, pp. 71-73.
} 
Já a autodefesa é considerada renunciável, porque não pode ser imposta ao acusado, embora não possa ser considerada dispensável pelo juiz. Seu cerceamento pode afetar a possibilidade de o acusado colaborar com seu defensor e o Juiz para a apresentação de considerações defensivas, o que pode resultar no prejuízo de toda a defesa. Inclui o direito de audiência (interrogatório) e o de presença (oportunidade de o acusado sempre tomar posição perante as alegações e as provas produzidas pela intermediação com o Juiz, razões e provas - comparecer, assistir e presenciar todos os atos processuais necessário ao convencimento motivado do Juiz, sobretudo os da fase instrutória, estar presente na sala de audiência e em contato com seu Defensor). ${ }^{387} \mathrm{O}$ estrangeiro submetido à jurisdição criminal no Brasil deve ser informado que, em certos casos, a lei processual penal confere ao réu, e concorrentemente à atuação do advogado, a faculdade de postular diretamente ao Juiz, assim como ocorre com a interposição de recursos (artigo 577 do Código de Processo Penal), o pedido de revisão criminal (artigo 623 do CPP) e a iniciativa para os procedimentos na execução penal (artigo 195 da Lei de Execuções Penais n.o 7210 de 11 de julho de 1984).

O contraditório é o meio essencial para a reação defensiva. É a oportunidade de a Defesa contrariar a acusação feita contra o réu. A reação defensiva é exercida durante todas as fases do processo, por meio de uma gama de direitos inerentes ao direito de defesa, como por exemplo, o direito do réu de ser ouvido perante o juiz da causa, para que possa apresentar diretamente a sua versão sobre o fato; o direito do acusado a ser informado e conhecer o teor da acusação que lhe é feita; o direito ao silêncio; o direito de ser defendido e de escolher um Defensor de sua confiança; o direito de intervir na investigação e na instrução; o de produzir prova; o de recorrer. ${ }^{388}$

Algumas são as fases processuais em que parece ser fundamental a intervenção do cônsul, e consequente efetivação da ampla defesa do estrangeiro. É o interrogatório o ato em que o réu fornece ao juiz as informações e declarações a respeito de sua pessoa e do fato criminoso a ele imputado, versando sobre seus

\footnotetext{
387 GrinOver, Ada Pellegrini; Gomes FILHO, Antonio Magalhães; e FernANDES, Antonio Scarance. As nulidades no Processo Penal, p. 73.

${ }^{388}$ FERNANDES, Antonio Scarance. A Reação Defensiva à Imputação, p. 31.
} 
antecedentes, personalidade, identidade e circunstâncias. Por ser um direito subjetivo do acusado, sua falta, quando possível a realização, acarreta em nulidade absoluta, por cercear-lhe uma possibilidade de defesa, assim como quando for realizado de forma coercitiva. O artigo 59 do Código Penal inclusive determina que para a imposição de pena, entre outras, o juiz deve levar em conta a personalidade do réu, oportunidade para o juiz levantar elementos úteis para a apuração da verdade.

FERNANDO DE ALMEIDA PEDROSO ${ }^{389}$ observa que, por constrangimento ou nervosismo em que se encontra o acusado no momento do interrogatório, ou até mesmo por falta de compreensão sobre o procedimento - até por falta de cultura para entender perguntas -, nem sempre estará em condições para elucidar os fatos de forma coerente, ou para declarar a sua versão pessoal dos fatos, podendo omitir circunstância relevante para a apuração da verdade. Isso quando o acusado é brasileiro; sem falar quando se tratar então de um estrangeiro na mesma situação. Aqui, a presença de defensor que possa contar com o apoio e autoridade do cônsul é de toda importância, até mesmo para informar-se sobre a cultura do país de origem daquele que ele defende, o sistema criminal, garantindo a função da fiscalização do ato. $\mathrm{O}$ cônsul pode garantir que os direitos fundamentais do acusado nacional do País o qual representa, estão sendo respeitados pelas autoridades competentes do Estado onde se encontra.

Para alcançar seus objetivos, o processo deve reconhecer e resolver os fatores de desigualdade real e desvantagens daqueles levados perante a justiça; daí o princípio da igualdade e a correlativa proibição de discriminação. No caso de réu estrangeiro, a assistência consular é um mecanismo que pode reduzir essa desvantagem. A presença de condições de desigualdade obriga a criação de mecanismos de compensação que reduzam obstáculos e deficiências que impeçam a efetivação da ampla defesa, e garantir o desfrute de um verdadeiro acesso à justiça com o beneficio do devido processo legal. ${ }^{390}$

\footnotetext{
${ }^{389}$ Pedroso, Fernando de Almeida. Processo Penal. O direito de defesa: repercussão, amplitude e limites, p. 181.

${ }^{390}$ Opinião Consultiva Número 16 de $1^{\circ}$ de outubro de 1999, solicitada pelos Estados Unidos Mexicanos perante à Corte Interamericana de Direitos Humanos. O direito de informação sobre a assistência consular no âmbito das garantias do Devido Processo Legal, parágrafo 119 .
} 
Em sendo o acusado estrangeiro, o Processo Penal brasileiro prevê alguns mecanismos de compensação - haverá intervenção de intérprete juramentado. Conforme o artigo 193 do Código de Processo Penal, o interrogatório será feito por intermédio do intérprete, garantindo a publicidade do ato, e a fiscalização por ambas as partes, defesa e acusação, isso desde que o acusado não entenda a língua nacional: "Quando o interrogando não falar a língua nacional, o interrogatório será feito por meio de intérprete." ${ }^{391}$ Os documentos escritos na língua nacional do acusado estrangeiro devem ser traduzidos para o português para que seu conteúdo torne-se a todos acessível (RT 637-238) ${ }^{392}$. A contrariu sensu, seria no mínimo razoável que os autos do processo, pelo menos as decisões judiciais e as peças apresentadas pelo Ministério Público, fossem também traduzidos para a língua do acusado, que tem o direito fundamental de conhecer o teor da acusação que lhe é imputada. Aqui se identifica outra forma de atuação do cônsul, que pode amortecer a situação de vulnerabilidade de seu conterrâneo privado de liberdade, ao providenciar a tradução das decisões e despachos importantes.

Quanto ao interrogatório, no caso de prisão em flagrante, é direta a relação com o direito de assistência consular. Conforme o artigo 36 da Convenção de Viena sobre Relações Consulares de 1963, o estrangeiro deve ser informado que tem o direito de contatar o Consulado de sua nacionalidade sem tardar. Para a Corte Internacional de Justiça, essa comunicação deve ser feita assim que as autoridades perceberem que se trata de estrangeiro; para a Corte Interamericana, o momento oportuno é antes de o estrangeiro prestar qualquer declaração, e antes do interrogatório. No caso de prisão em flagrante (artigo 302 do CPP), o interrogatório é um dos requisitos formais de validade do auto de prisão (artigo 304 do CPP), e sua falta pode anular o auto e invalidar a prisão, assim como a ausência de intérprete, e

\footnotetext{
391 "Acusado, estrangeiro, que domina o idioma português. Inocorrência de nulidade por falta de interprete, não demonstrado prejuízo para a defesa. Recurso de Habeas Corpus improvido." STF. RHC 65283 / RJ - Rio de Janeiro. Recurso em Habeas Corpus. Relator: Ministro Oscar Correa. Julgamento: 04/08/1987. Órgão Julgador: Primeira Turma.

${ }^{392}$ A autenticidade de documentos estrangeiros pode resultar (a) de seu trânsito por via diplomática ou (b) de sua legalização consular (Súmula 259/STF), impondo-se, sempre, a tradução de seu conteúdo para o idioma nacional, especialmente se produzidos em processos instaurados perante o Poder Judiciário brasileiro, "ainda que as partes e o Juiz tenham conhecimento do idioma alienígena, porque seu conteúdo deve ser acessível a todos" (RT 637/238). Essa tradução constitui formalidade indispensável (CPP, art. 236).
} 
assim como a não informação sobre o direito de assistência consular quando se tratar de estrangeiro.

A nomeação de advogado dativo pelo juiz não retira do acusado o direito de escolher o advogado de sua preferência, podendo, a qualquer tempo, com apresentação de motivos, substituir o que lhe foi nomeado (artigo 263 do CPP). Aqui a assistência do cônsul também pode ser importante, de auxiliar na indicação de advogado que seja mais conveniente para a efetiva defesa do estrangeiro.

O interrogatório ${ }^{393}$, no âmbito da autodefesa, enquanto direito de audiência, de meio de prova (até a promulgação da Lei 10.792 de 01/12/2003 ${ }^{394}$, cujo

\footnotetext{
${ }^{393}$ A Lei $\mathrm{n}^{\circ} 11.719$, de 20 de junho de 2008, que altera dispositivos do Decreto-Lei ${ }^{\circ} 3.689$, de 3 de outubro de 1941 - Código de Processo Penal, relativos à suspensão do processo, emendatio libelli, mutatio libelli e aos procedimentos, dispõe em seu artigo 400 que: "Na audiência de instrução $e$ julgamento, a ser realizada no prazo máximo de 60 (sessenta) dias, proceder-se-á à tomada de declarações do ofendido, à inquirição das testemunhas arroladas pela acusação e pela defesa, nesta ordem, ressalvado o disposto no artigo 222 deste Código, bem como aos esclarecimentos dos peritos, às acareações e ao reconhecimento de pessoas e coisas, interrogando-se, em seguida, o acusado. $\S$ lo As provas serão produzidas numa só audiência, podendo o juiz indeferir as consideradas irrelevantes, impertinentes ou protelatórias. $\$ 2^{\circ}$ Os esclarecimentos dos peritos dependerão de prévio requerimento das partes."

${ }^{394}$ Lei $^{\circ} 10.792$, de $1^{\circ}$ de dezembro de 2003, que altera a Lei $n^{\circ} 7.210$, de 11 de junho de 1984 - Lei de Execução Penal, e o Decreto-Lei no 3.689, de 3 de outubro de 1941 - Código de Processo Penal e dá outras providências. "Artigo 187. O interrogatório será constituído de duas partes: sobre a pessoa do acusado e sobre os fatos. $\S I^{\circ}$ Na primeira parte o interrogando será perguntado sobre a residência, meios de vida ou profissão, oportunidades sociais, lugar onde exerce a sua atividade, vida pregressa, notadamente se foi preso ou processado alguma vez e, em caso afirmativo, qual o juízo do processo, se houve suspensão condicional ou condenação, qual a pena imposta, se a cumpriu e outros dados familiares e sociais. $\S 2^{\underline{\alpha}} \mathrm{Na}$ segunda parte será perguntado sobre: I - ser verdadeira a acusação que the é feita; II - não sendo verdadeira a acusação, se tem algum motivo particular a que atribuí-la, se conhece a pessoa ou pessoas a quem deva ser imputada a prática do crime, e quais sejam, e se com elas esteve antes da prática da infração ou depois dela; III - onde estava ao tempo em que foi cometida a infração e se teve notícia desta; IV - as provas já apuradas; $V$ - se conhece as vítimas e testemunhas já inquiridas ou por inquirir, e desde quando, e se tem o que alegar contra elas; VI - se conhece o instrumento com que foi praticada a infração, ou qualquer objeto que com esta se relacione e tenha sido apreendido; VII - todos os demais fatos e pormenores que conduzam à elucidação dos antecedentes e circunstâncias da infração; VIII - se tem algo mais a alegar em sua defesa."A Lei $\mathrm{n}^{\mathrm{o}} 11.900$, de 8 de janeiro de 2009, que altera dispositivos do Decreto-Lei no 3.689, de 3 de outubro de 1941 - Código de Processo Penal, para prever a possibilidade de realização de interrogatório e outros atos processuais por sistema de videoconferência, e dá outras providência, dispõe que o artigo 185 do Código de Processo Penal passa a vigorar com os seguintes termos: " $\$ 1^{o}$ O interrogatório do réu preso será realizado, em sala própria, no estabelecimento em que estiver recolhido, desde que estejam garantidas a segurança do juiz, do membro do Ministério Público e dos auxiliares bem como a presença do defensor e a publicidade do ato. $\S 2^{\underline{o}}$ Excepcionalmente, o juiz, por decisão fundamentada, de ofício ou a requerimento das partes, poderá realizar o interrogatório do réu preso por sistema de videoconferência ou outro recurso tecnológico de transmissão de sons e imagens em tempo real, desde que a medida seja necessária para atender a uma das seguintes finalidades: I - prevenir risco à segurança pública, quando exista fundada suspeita de que o preso integre organização criminosa ou de que, por outra razão, possa fugir durante o deslocamento; II -
} 
artigo 185, § $2^{\circ}$ determina que: “Antes da realização do interrogatório, o juiz assegurará o direito de entrevista reservada do acusado com seu defensor"), passa a ser qualificado como meio de defesa do réu ${ }^{395}$ - de contestação da acusação e

viabilizar a participação do réu no referido ato processual, quando haja relevante dificuldade para seu comparecimento em juízo, por enfermidade ou outra circunstância pessoal; III - impedir a influência do réu no ânimo de testemunha ou da vítima, desde que não seja possível colher o depoimento destas por videoconferência, nos termos do artigo 217 deste Código; IV - responder à gravíssima questão de ordem pública. $\S 3^{0}$ Da decisão que determinar a realização de interrogatório por videoconferência, as partes serão intimadas com 10 (dez) dias de antecedência. $\$ 4^{o}$ Antes do interrogatório por videoconferência, o preso poderá acompanhar, pelo mesmo sistema tecnológico, a realização de todos os atos da audiência única de instrução e julgamento de que tratam os arts. 400, 411 e 531 deste Código. $\$ 5^{\circ}$ Em qualquer modalidade de interrogatório, o juiz garantirá ao réu o direito de entrevista prévia e reservada com o seu defensor; se realizado por videoconferência, fica também garantido o acesso a canais telefônicos reservados para comunicação entre o defensor que esteja no presídio e o advogado presente na sala de audiência do Fórum, e entre este e o preso. $\S 6^{\underline{a}}$ A sala reservada no estabelecimento prisional para a realização de atos processuais por sistema de videoconferência será fiscalizada pelos corregedores e pelo juiz de cada causa, como também pelo Ministério Público e pela Ordem dos Advogados do Brasil.\$ $7^{o}$ Será requisitada a apresentação do réu preso em juízo nas hipóteses em que o interrogatório não se realizar na forma prevista nos $\$ \S 1^{\circ}$ e $2^{\underline{o}}$ deste artigo. $\S 8^{o}$ Aplica-se o disposto nos $\S \S 2^{o}, 3^{\circ}, 4^{\underline{o}}$ e $5^{\underline{o}}$ deste artigo, no que couber, à realização de outros atos processuais que dependam da participação de pessoa que esteja presa, como acareação, reconhecimento de pessoas e coisas, e inquirição de testemunha ou tomada de declarações do ofendido. $\S 9^{\underline{0}}$ Na hipótese do $\S 8^{o}$ deste artigo, fica garantido o acompanhamento do ato processual pelo acusado e seu defensor."

395 "Habeas Corpus" - Necessidade de respeito, pelo poder público, às prerrogativas jurídicas que compõem o próprio estatuto constitucional do direito de defesa - a garantia constitucional do "due process of law" como expressiva limitação à atividade persecutória do Estado (investigação penal e processo penal) - o conteúdo material da cláusula de garantia do "due process" - interrogatório judicial - natureza jurídica - meio de defesa do acusado - possibilidade de qualquer dos litisconsortes penais passivos formular reperguntas aos demais co-réus, notadamente se as defesas de tais acusados se mostrarem colidentes - prerrogativa jurídica cuja legitimação decorre do postulado constitucional da ampla defesa - precedente do Supremo Tribunal Federal (Pleno) - magistério da doutrina - pedido deferido. A essencialidade do postulado do devido processo legal, que se qualifica como requisito legitimador da própria "persecutio criminis". - O exame da cláusula referente ao "due process of law" permite nela identificar alguns elementos essenciais à sua configuração como expressiva garantia de ordem constitucional, destacando-se, dentre eles, por sua inquestionável importância, as seguintes prerrogativas: (a) direito ao processo (garantia de acesso ao Poder Judiciário); (b) direito à citação e ao conhecimento prévio do teor da acusação; (c) direito a um julgamento público e célere, sem dilações indevidas; (d) direito ao contraditório e à plenitude de defesa (direito à autodefesa e à defesa técnica); (e) direito de não ser processado e julgado com base em leis "ex post facto"; $(f)$ direito à igualdade entre as partes; $(g)$ direito de não ser processado com fundamento em provas revestidas de ilicitude; (h) direito ao benefício da gratuidade; (i) direito à observância do princípio do juiz natural; (j) direito ao silêncio (privilégio contra a auto-incriminação); (l) direito à prova; $e$ (m) direito de presença e de "participação ativa" nos atos de interrogatório judicial dos demais litisconsortes penais passivos, quando existentes. - O direito do réu à observância, pelo Estado, da garantia pertinente ao "due process of law", além de traduzir expressão concreta do direito de defesa, também encontra suporte legitimador em Convenções Internacionais que proclamam a essencialidade dessa franquia processual, que compõe o próprio estatuto constitucional do direito de defesa, enquanto complexo de princípios e de normas que amparam qualquer acusado em sede de persecução criminal, mesmo que se trate de réu estrangeiro, sem domicílio em território brasileiro, aqui processado por suposta prática de delitos a ele atribuídos. O interrogatório judicial como meio de defesa do réu. - Em sede de persecução penal, o interrogatório judicial - notadamente após o advento da Lei $n^{o}$ 10.792/2003 - qualifica-se como ato de defesa do réu, que, além de não ser obrigado a responder a qualquer indagação feita pelo magistrado processante, também não pode sofrer qualquer restrição em sua esfera jurídica em virtude do exercício, sempre legítimo, dessa especial prerrogativa. Doutrina. Precedentes. Possibilidade jurídica de um dos litisconsortes penais 
oportunidade para o acusado expor sua própria versão dos fatos, podendo auxiliar o convencimento do Juiz, embora ainda sirva como "fonte de prova", e não como "meio de prova" - porque considera-se que o acusado não fornece elementos de prova. Não se busca a obtenção de confissão, mas sim dar oportunidade ao acusado de ser ouvido.

A Lei 10.792/2003 trouxe outra inovação para o artigo 188, que estabelece que, "Após proceder ao interrogatório, o juiz indagará das partes se restou algum fato para ser esclarecido, formulando as perguntas correspondentes se o entender pertinente e relevante." É indispensável que sobre todos os fatos o acusado possa desenvolver plenamente sua autodefesa, inclusive o estrangeiro, sendo que tudo será filtrado pelo Juiz. E pelo artigo 189 da mesma Lei, "se o interrogando negar a acusação, no todo ou em parte, poderá prestar esclarecimentos e indicar provas." Essas provas absolvitórias ou atenuantes podem estar no país de origem do preso - o Consulado pode atuar na coleta e fornecimento dessas provas, assim como eventuais traduções. Além de não ser obrigado a responder a qualquer indagação feita pelo Juiz, o acusado tampouco pode sofrer qualquer restrição em função dessa prerrogativa especial contra a auto-incriminação. O acusado estrangeiro deve estar ciente disso, para não causar eventual prejuízo à defesa e conseqüente nulidade absoluta.

O acusado tem a faculdade de não responder e "o direito ao silêncio é o selo que garante o enfoque do interrogatório como meio de defesa e que assegura a liberdade de consciência do acusado". ${ }^{396} \mathrm{O}$ artigo $5^{\circ}$, inciso LXIII, da Constituição de 1988 assegura que o "preso será informado de seus direitos, entre os quais o de permanecer calado, sendo-lhe assegurada a assistência da família e de advogado".

passivos, invocando a garantia do "due process of law", ver assegurado o seu direito de formular reperguntas aos co-réus, quando do respectivo interrogatório judicial. - Assiste, a cada um dos litisconsortes penais passivos, o direito - fundado em cláusulas constitucionais (CONSTITUIÇÃO DE 1988, artigo $5^{\circ}$, incisos LIV e LV) - de formular reperguntas aos demais co-réus, que, no entanto, não estão obrigados a respondê-las, em face da prerrogativa contra a auto-incriminação, de que também são titulares. $O$ desrespeito a essa franquia individual do réu, resultante da arbitrária recusa em lhe permitir a formulação de reperguntas, qualifica-se como causa geradora de nulidade processual absoluta, por implicar grave transgressão ao estatuto constitucional do direito de defesa. Doutrina. Precedente do STF. Habeas Corpus 94601/CE - Ceará; Relator: Ministro Celso de Mello; julgado em 04/08/2009; órgão julgador: Segunda Turma.

${ }^{396}$ GrinOVER, Ada Pellegrini; GoMES FILHO, Antonio Magalhães; e FERNANDES, Antonio Scarance. As nulidades no Processo Penal, p. 75. 
O direito ao silêncio é de qualquer acusado, e deriva do corolário inevitável dos princípios do devido processo legal, "Nemo tenetur se detegere" (ninguém é obrigado a se mostrar - princípio da vedação à auto-incriminação ou direito ao silêncio), da presunção de não culpabilidade e do processo acusatório. ${ }^{397} \mathrm{~A}$ advertência constitucional do direito de nada dizer deve ser assegurada de forma plena, sem pressões ou sanções, e não importará em confissão, não podendo ser interpretado em prejuízo à defesa. E isso se aplica também ao interrogatório policial, por força artigo $5^{\circ}$, inciso LXII, da Constituição de 1988, ou pelo disposto no artigo $6^{\circ}, \mathrm{V}$, do CPP no que for aplicável conforme ao disposto no seu Capítulo III do Título VII, do Livro I. ${ }^{398}$

É nesse sentido que pode ser fundamental à ampla defesa a atuação dos funcionários consulares. Isso porque, o estrangeiro, que desconhece o sistema processual penal brasileiro, ao qual está submetido, além do direito fundamental que tem de compreender o inteiro teor da acusação que lhe é feita e de um intérprete nomeado pelo Juiz, pode não entender que se nada disser no interrogatório, para evitar uma confissão, isso não o prejudicará e tampouco importará na presunção da confissão. O vício maior do interrogatório é justamente a falta de informação sobre o direito de o acusado ou indiciado de permanecer calado, o que implica na nulidade

397 Habeas Corpus 78708/SP - São Paulo. Relator: Min. Sepúlveda Pertence. Julgado em: 09/03/1999. Órgão Julgador: Primeira Turma.

398 " $O$ direito à informação da faculdade de manter-se silente ganhou dignidade constitucional a partir de sua mais eloqüente afirmação contemporânea em Miranda VS Arizona (384 US 436/1966), transparente fonte histórica de sua consagração na Constituição brasileira - porque intrumento insubstituível da eficácia real da vetusta garantia contra a auto-incriminação - Nemo tenetur prodere se ipsum, quia Nemo tenere detegere turpitudinem suam -. que a persistência planetária dos abusos policiais não deixa perder atualidade". Habeas Corpus 78708/SP - São Paulo. Relator: Min. Sepúlveda Pertence. Julgado em: 09/03/1999. Órgão Julgador: Primeira Turma. Ainda sobre o caso Miranda vs. Arizona, destacamos os seguintes trechos: “(b) The privilege against self-incrimination, which has had a long and expansive historical development, is the essential mainstay of our adversary system and guarantees to the individual the "right to remain silent unless he chooses to speak in the unfettered exercise of his own will," during a period of custodial interrogation [384 U.S. 436, 437] as well as in the courts or during the course of other official investigations. Pp. 458-465. (...)The person in custody must, prior to interrogation, be clearly informed that he has the right to remain silent, and that anything he says will be used against him in court; he must be clearly informed that he has the right to consult with a lawyer and to have the lawyer with him during interrogation, and that, if he is indigent, a lawyer will be appointed to represent him. Pp. 467-473. (e) If the individual indicates, prior to or during questioning, that he wishes to remain silent, the interrogation must cease; if he states that he wants an attorney, the questioning must cease until an attorney is present. Pp. 473-474. Prior to any questioning, the person must be warned that he has a right to remain silent, that any statement he does make may be used as evidence against him, and that he has a right to the presence of an attorney, either retained or appointed. The defendant may waive effectuation of these rights, provided the waiver is made voluntarily, knowingly and intelligently" 
do ato e sua invalidade, sendo necessário repetí-lo e, em último caso, todo o processo, no caso de o interrogatório ser considerado nulo. Isso porque o ato viciado resultou no sacrifício da autodefesa e, consequentemente, do direito de ampla defesa como um todo. ${ }^{399} \mathrm{O}$ funcionário consular, no exercício da assistência consular, pode atuar nesse sentido, ao indicar representação jurídica ao estrangeiro que seja sensível às suas limitações e vulnerabilidades, resultando, assim, na efetivação da sua ampla defesa, e nulidade processual penal absoluta. ${ }^{400}$

\subsection{O direito de defesa e as nulidades}

Finalmente, chega-se à etapa mais desafiadora da pesquisa, cujo objeto funda-se primordialmente no Direito Internacional Público. Eis o momento de suscitar indagações práticas sobre a relação entre Direito Internacional Público e direito interno, notadamente em matéria de processual penal, e o complicado mundo das nulidades processuais. A partir da interpretação dada pela Corte Internacional de Justiça e pela Corte Interamericana de Direitos Humanos ao artigo 36 da Convenção de Viena sobre Relações Consulares de 1963, questiona-se se seria possível demonstrar que o vício causado ao direito de informação sobre a assistência consular para o preso estrangeiro poderia causar-lhe um prejuízo a ponto de causar o reconhecimento de nulidade processual.

A atividade processual é regulada pelo Direito por um modelo de regras que devem ser obedecidas pelos que nela intervém, para atingir-se um provimento final justo. A fiel observância, por parte do Estado, dessas formas processuais estabelecidas em lei deve ser necessária para se atingir o próprio fim do modelo, dando segurança às partes e objetividade ao procedimento. E para serem considerados válidos e aptos a produzirem efeitos, e principalmente quando

\footnotetext{
${ }^{399}$ GRINOVER, Ada Pellegrini; GoMES FiLho, Antonio Magalhães; e FERnANDES, Antonio Scarance. As nulidades no Processo Penal, p. 77.

400 "RHC 32742/Recurso em Habeas Corpus. Relator: Ministro Barros Barreto. Julgamento: 07/10/1953. Órgão julgador: Primeira Turma. Delito de descaminho; apreensão da mercadoria; matéria de fato. Falta de intérprete para o interrogatório do réu estrangeiro; artigo 193 do código de processo penal. Anulação do feito, desde o interrogatório. Recurso provido, em parte."
} 
instituídas em favor do acusado, representam garantia de liberdade, pois o processo penal configura expressivo instrumento constitucional de salvaguarda dos direitos e garantias assegurados ao réu. A finalidade do cumprimento dessas solenidades é a de se garantir a realização plena do devido processo legal. ${ }^{401}$

Às partes deve-se garantir a plena participação nessa série de atos necessários à formação do convencimento judicial. Em contrapartida, no caso de desvio desses requisitos mínimos que formam esse modelo legal, o legislador estipula sanções que variam conforme o desatendimento das formas, que podem ser a inexistência $^{402}$ do ato; a irregularidade e; finalmente, a nulidade, pela qual a lei possibilita que se retire do ato a aptidão de produzir efeitos.

Nulo é o ato imperfeito, viciado, impuro, defeituoso, atípico, a que se aplicou a sanção da ineficácia, por conta da inobservância dos parâmetros normativos. $\mathrm{O}$ ato existe, mas por estar viciado pode perder toda eficácia jurídica. Nulidade é uma sanção de ineficácia imposta judicialmente a um ato atípico. Tanto o ato absolutamente nulo quanto o inexistente não produzem efeitos jurídicos. Será absolutamente nulo quando a lei não houver estabelecido a forma para convalidá-lo. Deve ser declarada de oficio pelo Juiz. Não se admite a convalidação de ato absolutamente nulo, no máximo a renovação ou retificação. ${ }^{403}$

Portanto, até mesmo por razões de economia processual, cabe ao juiz da causa, ao longo do iter processual, zelar pela rigorosa observância das formas legais e evitar irregularidades que possam tornar o processo inútil, determinando a realização dos atos omitidos, a renovação dos praticados em desconformidade com o modelo legal e a convalidação dos irregulares (quando permitido por lei). O juiz

\footnotetext{
${ }^{401}$ STF. Habeas Corpus 101474/SP - São Paulo. Relator: Ministro Celso de Mello. Julgado em: 05/10/2010. Órgão Julgador: Segunda Turma.

${ }^{402} \mathrm{O}$ vício do ato inexistente é de tamanha gravidade que sequer seria possível considerá-lo como sendo ato processual. Por isso que são não-atos. Um exemplo é a sentença proferida por quem não é Juiz. Em contrapartida, pode ser que o desacordo com o modelo legal seja muito pequeno, ou se trata de um formalismo insignificante sem afetar a validade do ato em si, preservando sua eficácia. São os atos irregulares (Artigo 564, IV do CPP: "A nulidade ocorrerá nos seguintes casos: (...) IV - por omissão de formalidade que constitua elemento essencial do ato";). Um exemplo é o oferecimento da denúncia fora do prazo legal, que deixa o Promotor sujeito a uma penalidade no âmbito administrativo pelo atraso.

${ }^{403}$ TouRINHO FILHO, Fernando da Costa. Processo Penal, pp. 112-116.
} 
pode resolver as preliminares suscitadas pelas partes, no momento da sentença, ou, de ofício, decretar a nulidade absoluta. As irregularidades que não forem reconhecidas na sentença podem ainda ser corrigidas em exame de eventual recurso, decretando-se a invalidade a partir do exame das preliminares; ou de ofício, no caso de recurso necessário ${ }^{404}$ ou nulidade absoluta. $\mathrm{O}$ desrespeito à forma deve ter prejudicado a defesa.

Quanto aos atos nulos, a ineficácia pode ainda ser relativa ou absoluta, e a diferença primordial entre ambas está em saber se a observância da forma do ato jurídico é para preservar no processo interesses de ordem pública. É relativa, a que o legislador confere à parte prejudicada a faculdade de pedir ou não a invalidação do ato praticado irregularmente, porque o vício não é tão grave a ponto de sua permanência afetar a efetividade do contraditório ou a justiça da própria decisão, da forma como ocorre com a nulidade absoluta, e afeta apenas o interesse das partes. O prejuízo deve ser sempre demonstrado pela parte, e somente haverá declaração do vício se não ocorrer outra possibilidade de se reparar o ato procedimental, devendo ser tempestivamente argüida pela parte, sob pena de saneamento pela preclusão da faculdade de alegar a irregularidade ${ }^{405}$, o que não ocorre com as nulidades absolutas, que podem ser argüidas a qualquer tempo. ${ }^{406}$

\footnotetext{
${ }^{404}$ Artigo574 do CPP:"Os recursos serão voluntários, excetuando-se os seguintes casos, em que deverão ser interpostos, de ofício, pelo juiz: I - da sentença que conceder habeas corpus; II - da que absolver desde logo o réu com fundamento na existência de circunstância que exclua o crime ou isente o réu de pena, nos termos do artigo 411."

${ }^{405} O$ instituto da preclusão decorre da própria essência da atividade processual; processo, etimologicamente, significa "marcha adiante" $e$, sendo assim, não teria sentido admitir-se que a vontade das partes pudesse, a qualquer momento, provocar o retrocesso a etapas já vencidas no curso procedimental; daí a perda, extinção ou consumação das faculdades concedidas às partes, sempre que não for observada a oportunidade legal para a prática de determinado ato ou, ainda, por haver o interessado realizado ato incompatível com outro. GRINOVER, Ada Pellegrini; GOMES FILHO, Antonio Magalhães; e Fernandes, Antonio Scarance. As nulidades no Processo Penal, p. 30.

${ }^{406}$ Conforme o artigo 571 do Código de Processo Penal: As nulidades deverão ser argüidas: $I$ - as da instrução criminal dos processos da competência do júri, nos prazos a que se refere o artigo 406; II as da instrução criminal dos processos de competência do juiz singular e dos processos especiais, salvo os dos Capítulos Ve VII do Título II do Livro II, nos prazos a que se refere o artigo 500; III - as do processo sumário, no prazo a que se refere o artigo 537, ou, se verificadas depois desse prazo, logo depois de aberta a audiência e apregoadas as partes; IV - as do processo regulado no Capítulo VII do Título II do Livro II, logo depois de aberta a audiência; V- as ocorridas posteriormente à pronúncia, logo depois de anunciado o julgamento e apregoadas as partes (artigo 447); VI - as de instrução criminal dos processos de competência do Supremo Tribunal Federal e dos Tribunais de Apelação, nos prazos a que se refere o artigo 500; VII - se verificadas após a decisão da primeira instância, nas razões de recurso ou logo depois de anunciado o julgamento do recurso e apregoadas as partes; VIII - as do julgamento em plenário, em audiência ou em sessão do tribunal, logo depois de ocorrerem.
} 
São, portanto, defeitos jurídicos, vícios ou erros relevantes, previstos pelos artigos 563 até 573 do Código de Processo Penal que, em linhas gerais, descrevem um rol de irregularidades de maior ou menor gravidade, e fixam regras gerais que devem ser obedecidas para o reconhecimento da nulidade do ato irregular.

O CPP adota os princípios gerais do prejuízo, causalidade, interesse e convalidação. ${ }^{407} \mathrm{O}$ artigo 572 do CPP trata em específico das nulidades sanáveis, pelo que se conclui que todas as demais não são passíveis de serem sanadas: as nulidades absolutas ${ }^{408}$, cujo vício também pode chegar a atingir o próprio interesse público de correta aplicação do direito. É por isso que o juiz, de ofício, deve decretar a invalidade do ato (salvo a exceção da Súmula 160 do STF, que dispõe que é nula a decisão do tribunal que acolhe, contra o réu, nulidade não arguida no recurso da acusação, ressalvados os casos de recurso de ofício).

\footnotetext{
${ }^{407}$ Causalidade existe quando a decretação da nulidade de determinado ato processual propaga-se para outros atos do procedimento, vez que o procedimento não é um ato isolado e independente, mas é constituído de cadeias de atos que visa à sentença final imparcial e justa. Pode ser originária ou derivada. Código de Processo Penal. Artigo 573. Os atos, cuja nulidade não tiver sido sanada, na forma dos artigos anteriores, serão renovados ou retificados. $\$ 1^{\circ}$ A nulidade de um ato, uma vez declarada, causará a dos atos que dele diretamente dependam ou sejam conseqüência. $\$ 2^{\circ} \mathrm{O}$ juiz que pronunciar a nulidade declarará os atos a que ela se estende. Quanto ao interesse, A decretação da invalidade do ato praticado irregularmente, renovando-o conforme o modelo legal deve estar sujeito a uma apreciação das vantagens dessa renovação para a parte que invoca a irregularidade, até para respeitar a praticidade do processo e economia processual. Não pode ser um simples capricho da parte. É nesse sentido que o artigo 565 do CPP estabelece que: "Nenhuma das partes poderá argüir nulidade a que haja dado causa, ou para que tenha concorrido, ou referente a formalidade cuja observância só à parte contrária interesse." Mas esse dispositivo diz respeito às nulidades relativas, porque dependem da argüição do interessado; não atingem o interesse público como as absolutas. Pode ser que a atividade processual atípica seja aproveitada em certas situações previstas em lei, sanada a irregularidade ou reparado o prejuízo, o ato praticado em desconformidade com o modelo legal pode ser convalidado, por ter atingido a finalidade, e que não tenha havido prejuízo para as partes (Exemplos de regras especiais de convalidação: artigo 568 do CPP: "A nulidade por ilegitimidade do representante da parte poderá ser a todo tempo sanada, mediante ratificação dos atos processuais." Artigo 569 do CPP: "As omissões da denúncia ou da queixa, da representação, ou, nos processos das contravenções penais, da portaria ou do auto de prisão em flagrante, poderão ser supridas a todo o tempo, antes da sentença final." Artigo 570 do CPP. "A falta ou a nulidade da citação, da intimação ou notificação estará sanada, desde que o interessado compareça, antes de o ato consumar-se, embora declare que o faz para o único fim de argüi-la. O juiz ordenará, todavia, a suspensão ou o adiamento do ato, quando reconhecer que a irregularidade poderá prejudicar direito da parte."

Grinover, Ada Pellegrini; Gomes Filho, Antonio Magalhães; e Fernandes, Antonio Scarance. As nulidades no Processo Penal, pp. 24-32

408 “Artigo572. As nulidades previstas no artigo 564, III, de e, segunda parte, g e h, e IV, considerarse-ão sanadas: I - se não forem argüidas, em tempo oportuno, de acordo com o disposto no artigo anterior; II - se, praticado por outra forma, o ato tiver atingido o seu fim; III - se a parte, ainda que tacitamente, tiver aceito os seus efeitos".
} 
$\mathrm{O}$ ato viciado é visto em função do conjunto que forma o procedimento como um todo. ${ }^{409}$ Ainda assim é preciso demonstrar se o vício ou a ausência do ato processual defensivo causa prejuízo à ampla defesa como um todo no caso concreto. É que entende o Supremo Tribunal Federal que para o reconhecimento de eventual nulidade, ainda que absoluta, faz-se necessária a demonstração do efetivo prejuízo ( $\mathrm{HC} \mathrm{n}^{\circ}$ 85.155/SP, de relatoria da Min. Ellen Gracie, DJ de 15/4/05) ${ }^{410}$. Conforme a interpretação da Súmula 523 do STF que dispõe que "no processo penal, a falta de defesa constitui nulidade absoluta, mas a sua deficiência só o anulará se houver prova de prejuízo para o réu". Assim, a nulidade é absoluta quando ficar provado que a defesa foi afetada como um todo, que houve o efetivo comprometimento das garantias processuais do acusado ou indiciado.

A infringência à norma constitucional com conteúdo de garantia (ao processo e às partes) sempre implicará nulidade de natureza absoluta, devendo ser decretada de ofício pelo juiz, "porque a obediência às regras do devido processo constitui requisito essencial para a correção da prestação jurisdicional". E quando se tratar de descumprimento de princípio ou norma constitucional com conteúdo processual a sanção provirá da própria Constituição ou do direito processual. Não há espaço para atos irregulares sem sanção, e tampouco para nulidades relativas, porque sendo a norma constitucional-processual de garantia revestida de interesse público pelo respeito ao devido processo, o ato processual inconstitucional será sempre absolutamente nulo, quando não for juridicamente inexistente ${ }^{411}$.

Uma nulidade absoluta pode ser argüida a qualquer momento, pois não está sujeita a causas impeditivas ou sanatórias. Mesmo após o trânsito em julgado de sentença condenatória ou absolutória imprópria pode-se argüir a nulidade

\footnotetext{
${ }^{409}$ GrINOVER, Ada Pellegrini; Gomes FILHO, Antonio Magalhães; e FernANDES, Antonio Scarance. As nulidades no Processo Penal, pp. 19 e 20.

410 HABEAS CORPUS. PROCESSO PENAL. TRÁFICO ILÍCITO DE ENTORPECENTES. PROCEDIMENTO. LEI 10.409/2002. NULIDADE. PREJUÍZO. 1. A demonstração de prejuízo, a teor do art. 563 do CPP, é essencial à alegação de nulidade, seja ela relativa ou absoluta, eis que, conforme já decidiu a Corte, "o âmbito normativo do dogma fundamental da disciplina das nulidades - pas de nullité sans grief - compreende as nulidades absolutas" (HC 81.510, rel. Min. Sepúlveda Pertence, $1^{a}$ Turma, unânime, DJ de 12.4.2002). 2. Ordem indeferida

${ }^{411}$ Não há de se falar em nulidade de ato inexistente, porque não se anula o que não existe, o que é inválido, em que não se verificam os elementos necessários para que possam surgir; são desprovidos de qualquer efeito ou significado jurídico. TourinHo FilHo, Fernando da Costa. Processo Penal, pp. 110-111.
} 
absoluta, mas desde que em favor da defesa.Quando se tratar de vício processual com repercussão efetiva ou potencial na liberdade do acusado caracteriza-se a coação ilegal corrigível por Habeas Corpus $^{412}$, admissível tanto no curso do feito como depois de prolatada a sentença, ainda que após o trânsito em julgado, enquanto não cumprida a pena, comprovada a existência do vício e sua ilegalidade. ${ }^{413}$ E depois por meio de ações autônomas como mandado de segurança e revisão criminal

Todo o cidadão, desde o momento da prisão, deve ser informado sobre seus direitos constitucionais, "entre os quais o de permanecer em silêncio, o de ter assistência da família e de advogado" (artigo 5, LXIII da Constituição de 1988), antes do interrogatório policial ou judicial; cujas eventuais declarações não podem ser utilizadas contra ele no futuro. O indiciado é sujeito de direitos e dispõe de garantias, legais e constitucionais, cuja inobservância, pelos agentes do Estado, além de eventualmente induzir-lhes a responsabilidade penal por abuso de poder, pode gerar a absoluta desvalia das provas ilicitamente obtidas no curso da investigação policial. $^{414}$

E a falta de informação ao preso sobre seus direitos constitucionais gera nulidade dos atos praticados, quando verificado o prejuízo. ${ }^{415}$ Assim, eventual confissão feita aos policiais antes de o réu tomar conhecimento de seu direito constitucional ao silêncio, não pode ser usada contra ele na sentença que o julgar, sob pena de violação dessa garantia constitucional e da conseqüente nulidade da sentença. $\mathrm{O}$ próprio artigo $5^{\circ}$, inciso LVI, da Constituição prevê que "são inadmissíveis, no processo, as provas obtidas por meios ilícitos."

\footnotetext{
412 Artigo $5^{\circ}$ LXVIII da Constituição Federal: "conceder-se-á "habeas-corpus" sempre que alguém sofrer ou se achar ameaçado de sofrer violência ou coação em sua liberdade de locomoção, por ilegalidade ou abuso de poder." Artigo648 do CPP. A coação considerar-se-á ilegal (...) VI - quando o processo for manifestamente nulo".

${ }^{413}$ GrinOVER, Ada Pellegrini; GoMES FILHO, Antonio Magalhães; e FERNANDES, Antonio Scarance. As nulidades no Processo Penal, pp. 34-35.

414 STF. Habeas Corpus 73271 SP - São Paulo. Relator: Ministro Celso de Mello. Julgado em 19/03/1996. Órgão Julgador: Primeira Turma.

${ }^{415}$ STF. Recurso em Habeas Corpus 79.973. Minas Gerais. Relator: Ministro Nelson Jobim. Julgado em 23/05/2000.

${ }^{416}$ É o que ressalta o Ministro Relator SEPÚlVEdA PERTENCE, em seu voto no julgamento do Habeas Corpus 78.708-1 do Supremo Tribunal Federal: "Tenho assim, que, em princípio, ao invés de constituir desprezível irregularidade, a omissão do dever de informação ao preso dos seus direitos, no momento adequado, gera efetivamente nulidade e impõe a desconsideração de todas as informações incriminatórias dele anteriormente colhidas, assim como das provas nela derivadas.
} 
Na sentença do caso AvenA, datada de 27 de junho de 2004, a Corte Internacional de Justiça fixa o entendimento que o direito de comunicação com o consulado da nacionalidade do preso estrangeiro seja informado ao preso exatamente no momento da prisão, assim que se perceber que se trata de um estrangeiro. A CIJ afirma que a prestação desse direito de assistência consular poderia ser efetivada em paralelo à leitura dos direitos de que qualquer pessoa levada sob custódia em decorrência de uma ofensa criminal, antes do interrogatório, por força do que nos Estados Unidos é conhecido como a "regra de Miranda", cujos direitos incluem o direito de permanecer calado, o direito de ter um advogado presente durante o interrogatório e o direito de ter um advogado nomeado às custas do governo, se a pessoa não puder pagar por um. ${ }^{417}$

Depois deste breve estudo sobre as nulidades processuais, passa-se a seguir à indagação sobre como a violação do artigo 36 da Convenção de Viena sobre Relações Consulares de 1963 poderia afetar o direito de ampla defesa.

\subsection{A hipótese de a violação do artigo 36 da Convenção de Viena sobre Relações Consulares de 1963 afetar o direito de ampla defesa à luz do Direito brasileiro}

Cometido um fato que a lei considera como crime, o EstadoAdministração, no intuito de salvaguardar a paz e a ordem pública, inicia a persecutio criminis contra seu autor, na busca da verdade real - respeitada a natureza preventiva da pena, para corresponder à natureza e gravidade do delito. $\mathrm{O}$ réu tem o direito de se opor a que a pretensão do autor venha a atingir a tutela jurídica de seus interesses. Essa faculdade de oposição se conhece como direito de defesa, que consiste na possibilidade de influir o acusado no processo como um de seus modeladores, "como o poder de criar situações processuais e reforçar sua perspectiva de sentença favorável, bem como no direito de manifestar sua

Habeas Corpus 78708/SP - São Paulo. Relator: Min. Sepúlveda Pertence. Julgado em: 09/03/1999. Órgão Julgador: Primeira Turma, p. 888.

${ }^{417}$ Case concerning Avena and other Mexican nationals (Mexico v. United States of America), ICJ Reports of Judgments, advisory opinions and orders (27/06/2004), § 64. 
apreciação final sobre as quaestiones facti e quaestiones júris." O réu se sujeita ao processo e à sentença que vier a ser prolatada, que pode privá-lo de seu status dignitatis que é a própria liberdade. Imperioso é o Estado oferecer-lhe todas as possibilidades para contrariar o que lhe acusam, como eventuais irregularidades no procedimento estatal. É o direito de ser ouvido e de atuar para a demonstração da verdade, ou para que dificulte ou impeça a sua tonalização. É o fundamento primário da segurança jurídica na vida social organizada, porque o acusado não é simples material de investigação, mero espectador ou simples objeto. ${ }^{418}$

A contradição permite, entre o cometimento do delito e a aplicação da pena, um choque de versões para obter-se a verdade real e o julgamento justo. Não cabe apenas ao órgão estatal acusatório deduzir os fatos e provas sobre os quais almeja a incidência de conseqüências jurídico-criminais. $\mathrm{O}$ réu pode agir no sentido de obter uma sentença favorável, já que lhe socorrem o in dúbio pro reo e o non liquet. Com a instauração do processo, o réu assume posição atuante, e tem assegurado o direito de oferecer sua versão dos fatos, ou o de nada contribuir para que contra si possa perfazer-se a verdade real. ${ }^{419}$

Para Fernando de Almeida Pedroso, em vista do princípio da isonomia de todos perante a lei, o réu tem o direito de atuar probatoriamente em igualdade de condições com o órgão estatal acusatório. Caso contrário, o direito de defesa seria simples quimera jurídica, uma mera formalidade, e não um efetivo direito fundamental, estando editado na nossa Constituição Federal (art. $5^{\circ}$, LV) que a lei assegurará aos acusados ampla defesa, com os recursos a ela inerentes (efetividade do direito), e que a instrução criminal será contraditória - é a antítese apresentada pelo réu aos motivos e razões em que se baseia a acusação; um direito contraposto ao direito de ação. Junto ao acusado projeta-se seu defensor para a defesa técnica, para se conceber um verdadeiro contraditório, com paridade de armas, o reflexo do pressuposto processual da capacidade postulatória. Assim, seu cerceamento, em qualquer uma de suas manifestações tornará írrito o feito criminal,

\footnotetext{
${ }^{418}$ PedRoso, Fernando de Almeida. Processo Penal. O direito de defesa: repercussão, amplitude e limites, pp. 27-30.

${ }^{419}$ Pedroso, Fernando de Almeida. Processo Penal. O direito de defesa: repercussão, amplitude e limites, pp.30-33.
} 
inquinando o processo e fazendo-o repousar sobre a sanção da nulidade, ou impedimento da produção de efeitos de determinados atos processuais. É um direito sagrado da persecutio criminis. ${ }^{420}$

ANTONIO SCARANCE ${ }^{421}$ ensina que o processo penal é a busca do equilíbrio entre assegurar ao Estado os meios para exercer, com eficácia, o seu poder punitivo, e o de garantir a todo indivíduo o direito de se defender com plenitude antes de ser julgado. Para ele, o ideal seria um regime constitucional e processual que conjugasse eficiência e garantismo, objetivo difícil de ser alcançado. Não se pode conceber um Estado democrático sem as garantias fundamentais mínimas do devido processo legal, entre elas a oportunidade de reagir amplamente à acusação, em posição de equilíbrio. Assim, não podem vigorar orientações restritivas à reação defensiva. Defesa é o direito de o indivíduo reagir à ação contra si proposta para evitar a condenação e imposição da pena.

As pessoas que imigram têm diferentes características e problemas, por razões étnicas, religiosas, sociais e culturais. Em geral, constituem um setor da população que se encontra em situação especial de vulnerabilidade, porque, na maioria dos casos, sequer possuem um conhecimento básico do idioma do Estado onde se encontram. Ademais, o estrangeiro geralmente desconhece a cultura, as estruturas jurídicas, sociais e políticas desse país. Especialmente os indocumentados enfrentam situações em que são restringidos de proteção jurídica adequada, ficando mais expostos a sofrerem abusos e arbitrariedades.

A falta de documentação também fomenta a impunidade contra esses imigrantes, porque os impede de garantir seus direitos na justiça, quando violados, igualmente dificulta o acesso a serviços e trabalho. Além disso, enfrentam situações discriminatórias, de gênero, racismo, xenofobia, estigmatização social. ${ }^{422} \mathrm{O}$ direito

\footnotetext{
${ }^{420}$ Pedroso, Fernando de Almeida. Processo Penal. O direito de defesa: repercussão, amplitude e limites, pp. 32, 54-55

${ }^{421}$ FERNANDES, Antonio Scarance. Reação Defensiva à Imputação, pp. 21 e 22.

${ }^{422}$ ELIZONDO, Gonzalo e CASAFONT, Paola. Migración y dinâmica de los derechos humanos hoy. In: Os Rumos do Direito Internacional dos Direitos Humanos. Ensaios em Homenagem ao Professor Antônio Augusto Cançado Trindade. Liber Amicorum Cançado Trindade, pp. 281282.
} 
de informação sobre assistência consular para preso estrangeiro é de transcendental importância, sobretudo no mundo interconectado de hoje, em que a migração é um fenômeno. No exterior, o estrangeiro submete-se às mesmas leis que os nacionais, e não pode ser discriminado. No entanto, ao se deparar com situações adversas, como a privação da liberdade, corre sim o risco de sofrer discriminação e ter prejudicado o direito fundamental de ampla defesa, situação que exige medidas de compensação que o funcionário consular pode ajudar a remediar.

A partir da análise da Opinião Consultiva n. ${ }^{\circ}$ 16, de 01 de outubro de 1999, realizada anteriormente, a Corte Interamericana de Direitos Humanos reconheceu que para fim de o devido processo legal ser preservado, o acusado sujeito a um procedimento penal deve ter condições efetivas de exercer seus direitos e defender seus interesses, em total igualdade procedimental, com relação a outros acusados, assegurando-se, na maior medida do possível, a solução justa e equitativa de um processo penal. Na circunstância de ser o preso um estrangeiro, a informação sobre o direito de comunicar-se com o representante consular de seu país contribuirá significativamente para melhorar de forma considerável suas possibilidades de defesa. A inobservância desse direito de informação sobre o direito de comunicação com o posto consular da nacionalidade do preso estrangeiro, por parte das autoridades competentes do Estado Receptor, no nosso caso o Brasil, afeta as garantias judiciais do devido processo legal, sem falar que fere o princípio da igualdade, previsto inclusive na Carta da Organização dos Estados Americanos. ${ }^{423}$

Reconheceu a Corte Interamericana que a assistência consular constitui um importante meio para a defesa do acusado, que repercute em certas situações de forma decisiva para o respeito de seus outros direitos processuais. Assim, a Corte consagrou o direito de assistência consular no corpo direitos humanos, entre o pacote dos componentes das garantias mínimas do devido processo legal.

\footnotetext{
${ }^{423}$ Opinião Consultiva Número 16 , de $1^{\circ}$ de outubro de 1999 , solicitada pelo México perante à Corte Interamericana de Direitos Humanos. O direito de informação sobre a assistência consular no âmbito das garantias do Devido Processo Legal, §s 117-129 e 137.
} 
O juiz Sergio García RAmírez ressaltou em voto em separado, na Opinião Consultiva n.o 16/99 que as novas circunstâncias da vida social trazem consigo diversas necessidades que devem ser atendidas com instituições adequadas, que antes pareciam desnecessárias, e hoje são indispensáveis - o direito de conhecer o teor da acusação, por exemplo, foi reforçado com o direito a um intérprete quando não se conhece o idioma a que se está submetido. O conhecido devido processo legal, jamais uma realidade esgotada, é o resultado de uma longa marcha, alimentada por lei, doutrina e jurisprudência, tanto no plano nacional como no internacional, cujos componentes são superados por novos desenvolvimentos, dentro da concepção democrática de justiça penal. É nesse contexto dinâmico ele afirma: "si el derecho a la información consular ya forma parte del conjunto de derechos y garantías que integran el debido proceso, es evidente que la violación de aquél trae consigo las consecuencias que necesariamente produce una conducta ilícita de esas características: nulidad y responsabilidad”. ${ }^{424}$ Trata-se de direito que brinda os estrangeiros com a oportunidade de preparar sua defesa de forma adequada, e contar com um juiz justo. ${ }^{425}$

A razão subjacente da assistência consular é que ao se comunicar com seus nacionais, os funcionários consulares podem garantir que seus direitos humanos fundamentais sejam respeitados, e confirmar a integridade física e o estado mental do súdito, bem como verificar que não houve violação de seus direitos (por exemplo, excesso durante a prisão, coerção para confessar). O acesso consular oportuno também é fundamental nos processos criminais, porque permite que o cônsul realize uma série de serviços, incluindo consultoria sobre o sistema jurídico do Estado ao qual o estrangeiro está submetido, verificação do status imigratório do acusado. Isso permite que o acusado conheça seus direitos, deveres e benefícios. ${ }^{426}$

\footnotetext{
${ }^{424}$ Opinión Consultiva n. ${ }^{\mathbf{0}} 16 / 99$ del 1 de octubre de 1999. El Derecho a la Información sobre la Asistencia Consular en el Marco de las Garantías del Debido Proceso Legal, Voto concordante do JUIZ SÉRGIO GARCIA RAMIREZ, pp. 01-03.

${ }^{425}$ Opinião Consultiva Número 16 , de $1^{\circ}$ de outubro de 1999 , solicitada pelo México perante à Corte Interamericana de Direitos Humanos. O direito de informação sobre a assistência consular no âmbito das garantias do Devido Processo Legal, §s 106, 118, 122 e 123.

${ }^{426}$ BUYS, Cindy Galway. Strangers in a Strange Land: The Importance of Better Compliance with Consular Notification Rights, p. 08. Disponível online em: $<$ http://papers.ssrn.com/sol3/papers.Constituição de 1988m?abstract_id=1651310>.
} 
Exercida em tempo oportuno, a assistência consular é, portanto, situação real que ampara os estrangeiros sujeitos a um procedimento penal, porque auxilia para que eles recebam tratamento justo e igualitário por parte dos tribunais locais e das autoridades penais do Estado receptor. Dentre outras funções, por exemplo, a assistência consular pode acarretar a presença de advogado e intérprete pessoal para a fase pré-processual conhecida como inquisitorial, e para o acompanhamento da lavratura de atos procedimentais, principalmente em relação àqueles relativos ao interrogatório policial e ao indiciamento. No curso da ação penal, o acusado estrangeiro não pode interferir na nomeação de intérprete pelo Juiz, que cumpre a função de perito, mas outro intérprete fornecido pelo Consulado permite que o estrangeiro entenda e conheça, juntamente com seu advogado nomeado ou dativo, certos direitos como o de ficar calado e de não responder perguntas que lhe forem formuladas, e que esse direito de silêncio não lhes importará em confissão, e não poderá ser interpretado em prejuízo da defesa. E também a presença de intérprete se necessária a acareação, para a explicação de pontos divergentes.

É importante que o Consulado possa informar à Defesa do estrangeiro o que significa a assistência consular no preparo de um plano de contingência legal para intervir num caso em que o artigo 36 da Convenção tenha sido violado, na alegação de eventual nulidade, ou quando um de seus nacionais enfrenta uma acusação muito grave. O funcionário consular pode assegurar que indivíduo nessa situação receba a assistência jurídica adequada e conheça as conseqüências legais do delito que lhe imputam.

Por fim, é preciso refletir sobre a efetiva incorporação dos termos da Convenção de Viena sobre Relações Consulares de 1963 no ordenamento positivo brasileiro, à luz do que foi interpretado pelos tribunais internacionais. $\mathrm{O}$ vício desse importante componente do devido processo penal poderá acarretar em nulidade processual penal absoluta, em qualquer fase, sempre que demonstrado o prejuízo aos princípios constitucionais da ampla defesa e do contraditório. O inciso LV do artigo $5^{\circ}$ da Constituição Federal garante como direito fundamental que é que "aos litigantes, em processo judicial ou administrativo, e aos acusados em geral são 
assegurados o contraditório e ampla defesa, com os meios e recursos a ela inerentes”. No dispositivo, embora não se mencione explicitamente o estrangeiro, é plausível que o termo "em geral" refira-se a ele. Já o inciso LXIII do mesmo dispositivo estabelece os direitos do preso: "o preso será informado de seus direitos, entre os quais o de permanecer calado, sendo-lhe assegurada a assistência da família e de advogado." Sugere-se que a expressão "entre os quais" reflete que não são estáticos os direitos dos presos, que não se limitam ao direito ao silêncio, à assistência da família e a um advogado. É justamente pela interpretação dos presentes dispositivos que se entende que aqui se incluem também o direito de o estrangeiro ser informado de que tem direito de comunicar-se com o seu Consulado, na forma como determina o artigo 36 da Convenção de Viena de 1963, incorporada ao ordenamento positivo brasileiro por força do Decreto $\mathrm{n}^{\circ} 61.078$, de 26 de julho de 1967.

\subsection{A atuação do Brasil como Estado que envia na assistência consular a brasileiros presos no exterior}

Muito embora este trabalho seja fruto de uma pesquisa cujo objeto principal foi o estudo da casuística internacional sobre a violação do direito de informação sobre assistência consular para preso estrangeiro, e os efeitos disso no Direito brasileiro, é de todo cabível, nesta etapa final, mencionar o trabalho desenvolvido pelo Ministério das Relações Exteriore quanto à atuação do Brasil como Estado que envia. A título de curiosidade, destaca-se aqui o papel do Itamaraty na prestação de assistência consular para brasileiros em situação de privação de liberdade em Estados Receptores afora.

O Brasil está empenhado no aprimoramento da efetivação da assistência consular para seus súditos no exterior. A SUBSECRETARIA GERAL DAS COMUnidades Brasileiras NO EXTERIOR (SGEB), do Ministério das Relações Exteriores, tem desempenhado papel importantíssimo para assegurar o tratamento justo e equânime para os brasileiros que se encontram em outros Estados. O Decreto 
$\mathrm{n}^{\mathrm{o}} 7.214$, de 15 de junho de 2010, que estabelece princípios e diretrizes da política governamental para as comunidades brasileiras no exterior, institui as Conferências Brasileiros no Mundo - CBM, cria o Conselho de Representantes de Brasileiros no Exterior - CRBE, e dá outras providências, é o espelho desse empenho. Outro fator importante é o empenho do Brasil em aprimorar seus serviços consulares tradicionais, a atividade consular clássica e também passar a prestar outros em benefício de seus nacionais no exterior, os denominados "serviços de segunda geração", que visam à educação, cultura, saúde, trabalho e previdência social desses compatriotas, à preservação dos seus vínculos com o Brasil, sua inserção harmoniosa nas sociedades locais, sua valorização e seu aproveitamento para fins de divulgação do Brasil no exterior. Nesse sentido, o Itamaraty vem construindo e institucionalizando, de forma evolutiva e democrática, uma nova forma de interlocução firme com os brasileiros que se encontram no exterior.. ${ }^{427}$

Uma das prioridades da SUbSECRETARIA GERAL DAS COMUNIDADES BRASILEIRAS NO EXTERIOR ${ }^{428}$ é prestar apoio às comunidades brasileiras mais vulneráveis ou de maior dimensão no exterior, assim como conhecê-las, valorizá-las,

\footnotetext{
427 "Naturalmente não passa despercebida a outros países a firmeza do Brasil na proteção dos seus nacionais no exterior. Exemplos disso foram, entre outros, a reação brasileira à morte de Jean Charles de Menezes em Londres em 2005 como resultado de ação anti-terrorista equivocada da polícia londrina, o resgate de 3 mil brasileiros do Líbano em 2006, a defesa da reciprocidade perante a Espanha durante a crise dos inadmitidos de 2008 e os pronunciamentos oficiais do Brasil em relação à Diretiva de Retorno, ao Pacto Europeu sobre Imigração e Asilo e a outras medidas européias ou nacionais de controle que, na percepção do Governo brasileiro, ferem ou abrem possibilidades de ferir a dignidade e os direitos de viajantes e migrantes brasileiros. Por outro lado, pode ser constatada a disposição do Governo brasileiro de reconhecer certos aspectos menos favoráveis em relação à sua diáspora e de procurar modificá-los; de colaborar em matéria migratória com outros países em projetos que busquem inibir a imigração irregular e combater o crime transnacional, desde que não atentem contra a soberania brasileira, não discriminem nossos nacionais e não pressuponham arbitrariamente seus comportamentos futuros; de respeitar estritamente o direito internacional, acordos e outros compromissos assumidos em matérias consulares e migratórias; e de encontrar fórmulas criativas e consensuais para equacionar problemas de alta complexidade envolvendo seus nacionais no exterior, como por exemplo através das jornadas migratórias no Paraguai e dos programas de reassentamento na Bolívia". EMBAIXADOR EDUARDO GRAdILONE, Subsecretário-Geral das Comunidades Brasileiras no Exterior SGEB, A política consular e de apoio a brasileiros como fator de credibilidade e afirmação externa do Brasil, disponível online em: <http://sistemas.mre.gov.br/kitweb/datafiles/IRBr/pt-br/file/CAD/SGEB\%20\%20Palestra\%20SGEB\%20na\%20CNPEPI-FUNAG\%202010.pdf> (acesso em 31/10/2010).

${ }^{428}$ Mais informações sobre a SUBSECRETARIA GERAL DAS COMUNIDADES BRASILEIRAS NO EXTERIOR encontram-se disponíveis online em: < http://www.itamaraty.gov.br/o-ministerio/conheca-oministerio/comunidades-brasileiras/sgeb-subsecretaria-geral-das-comunidades-brasileiras-noexterior> (acesso em 04/04/2011).
} 
desenvolvê-las, protegê-las e mantê-las vinculadas ao Brasil. A Subsecretaria desenvolve ainda intenso trabalho nas áreas jurídica, de imigração e de atos internacionais. $^{429}$

"Brasileiros no Mundo", a I Conferência das Comunidades Brasileiras no Exterior, foi realizada no Rio de Janeiro nos dias 17 e 18 de julho de 2008, sob patrocínio da SUBSECRETARIA-GERAL DAS COMUNIDADES BRASILEIRAS NO EXTERIOR (SGEB) e da FundaÇÃo AleXAndre de Gusmão (FUNAG), do Ministério das Relações Exteriores (MRE). O objetivo principal do encontro foi permitir debate de assuntos sobre emigração brasileira e políticas públicas para brasileiros no exterior. Representantes dos Ministérios das Relações Exteriores, do Trabalho e Emprego, da Previdência Social e da Educação, entre outros, apresentaram trabalhos sobre ações em curso ou cogitadas nessa área. Acadêmicos renomados elaboraram estudos sobre a diáspora brasileira. ${ }^{430}$

A II Conferência das Comunidades Brasileiras no Exterior, também denominada "Brasileiros no Mundo", foi realizada no Rio de Janeiro nos dias 14, 15, 16 de outubro de 2009, igualmente no Palácio Itamaraty. Nos mesmos moldes de

429 A SGEB compõe-se do Departamento Consular e de Brasileiros no Exterior (DCB), do Departamento de Imigração e Assuntos Jurídicos (DIJ), e da Ouvidoria Consular (OUV). A SGEB compreende também o Núcleo de Modernização Consular (NMCONS), responsável pela coordenação do tema no âmbito da Subsecretaria. Entre os principais temas tratados atualmente pela SGEB e por seus departamentos, incluem-se: Estabelecimento de uma nova interação MRE-diáspora, por intermédio das Conferências "Brasileiros no Mundo", em parceria com a Fundação Alexandre de Gusmão; Negociações com o Paraguai sobre temas do interesse dos chamados "brasiguaios", tais como a implementação de acordos de regularização migratória e de residência do Mercosul, cooperação em censos dos respectivos nacionais e solução de conflitos de natureza fundiária; Negociações com a Bolívia sobre brasileiros a serem eventualmente transferidos da faixa de fronteira Norte nos Departamentos do Pando e Beni e reassentados em outras áreas, segundo acordo trilateral firmado entre Brasil, Bolívia e Organização Internacional para as Migrações (OIM); Negociações com a Espanha, Reino Unido, França, Itália, Portugal e outros países desenvolvidos sobre questões migratórias e circulação de pessoas, bem como inadmissões de brasileiros em aeroportos europeus; Implantação do Sistema Consular Integrado (SCI) para a completa informatização dos serviços de emissão de passaportes, vistos e documentos notariais pela rede consular brasileira; Elaboração de documento-base para a elaboração de um Programa Diretor de Reforma Consular, baseado nos resultados de amplo exercício de reflexão, lançado pelo MRE em 2007, sobre formas de aprimorar o serviço consular brasileiro.

${ }^{430} \mathrm{O}$ evento inédito reuniu, pela primeira vez, centenas de representantes das principais comunidades brasileiras nos EUA, na América do Sul, na Europa Ocidental, no Japão, na Austrália, na África e no Oriente Médio, com a finalidade de debater assuntos do interesse da diáspora brasileira. Estiveram presentes à Conferência autoridades dos Poderes Executivo, Legislativo e Judiciário, bem como membros do mundo acadêmico, da mídia, de organismos internacionais e de entidades nãogovernamentais. Também participaram Cônsules e chefes de setores de missões diplomáticas que se ocupam do apoio às comunidades brasileiras no exterior de maior dimensão, bem como altas chefias do Itamaraty em Brasília. 
presença de autoridades, discutiram-se temas como: cultura e educação; trabalho, previdência e saúde; serviços consulares e regularização migratória; representação política.

O Decreto $\mathrm{n}^{\circ} 7.214$ de 15 de junho de 2010, entre outros, instituiu a AtA CONSOldDADA, que procura reunir, de forma estruturada, as principais demandas apresentadas pelas comunidades brasileiras no exterior durante os últimos oito anos, incluindo as consignadas no Documento de Lisboa de 2002, na Carta de Boston de 2005, no Documento de Bruxelas de 2007 e nas Atas das duas, primeiras “Conferências Brasileiros no Mundo", realizadas em 2008 e 2009. ${ }^{431}$

\section{A III Conferência "Brasileiros no Mundo" (CBM) realizou-se nos dias}

2 e 3 de dezembro de 2010, no mesmo local das anteriores, com presença do Presidente da República, no dia 3, e do Ministro das Relações Exteriores, e de oito Ministros de Estado ${ }^{432}$. Do evento resultou a ATA CONSOLIDADA DE REIVINDICAÇÕES DAS COMUNIDADES BRASILEIRAS NO EXTERIOR. ${ }^{433}$ Entre uma das principais

\footnotetext{
${ }^{431}$ O objetivo do Portal "Brasileiros no Mundo" é instrumentar e ampliar o diálogo entre o Ministério das Relações Exteriores e as comunidades brasileiras no exterior, e destas entre si. É possível acessar informações sobre as comunidades brasileiras no exterior, como compilações de organizações e veículos de imprensa e mídia de brasileiros no exterior, estimativas populacionais e referências bibliográficas. O Portal também apresenta notícias sobre ações do Governo de interesse dos brasileiros residentes no exterior, informações sobre o sistema de Conferências "Brasileiros no Mundo" e sobre o processo de eleição para o Conselho de Representantes de Brasileiros no Exterior. Disponível online em: <http://www.brasileirosnomundo.mre.gov.br/pt-br/> (acesso em 15/03/2011).

${ }^{432}$ Esta candidata ao título de Mestre em Direito Internacional pela Faculdade de Direito da Universidade de São Paulo, graças ao convite pessoal realizado pelo Excelentíssimo Embaixador EDUARDO GRADILONE, Subsecretário-Geral das Comunidades Brasileiras no Exterior em outra oportunidade de evento oferecido pela FUNDAÇão ALEXANDRE DE GUSMÃO, no Itamaraty-Rio de Janeiro em novembro de 2010, após conhecer o tema escolhido, teve a honra de estar presente no evento e vivenciar na prática os anseios e dificuldades enfrentadas pelos nossos representantes diplomáticos no exterior, que em muito enriqueceu esta pesquisa. O evento contou com a presença do Senhor Presidente da República em sessão solene, no dia 3/12, e de oito Ministros de Estado, além do Ministro das Relações Exteriores, Celso Amorim: Luís Dulci da Secretaria Geral/PR; Franklin Martins, da Secretaria de Comunicação Social da Presidência; Carlos Eduardo Gabas da Previdência Social; Márcia Lopes do Desenvolvimento Social e Combate à Fome; Carlos Lupi do Trabalho e Emprego; Sérgio Rezende, da Ciência e Tecnologia; Juca Ferreira, da Cultura; e Márcio Fortes, das Cidades, além de deputados, senadores e a Presidente da TV Brasil, Thereza Cruvinel. Igualmente, participaram o Governador do Estado do Rio de Janeiro, Sérgio Cabral e o Prefeito da cidade do Rio de Janeiro, Eduardo Paes, 43 Embaixadores e Cônsules-Gerais do Brasil, além do Embaixador de Portugal e representantes consulares de outros países. Realizaram-se, ainda, reuniões temáticas, no dia 2/12 e de representantes das quatro regiões geográficas da CBM (América do Sul e Central; América do Norte e Caribe; Europa; Ásia, África, Oriente Médio e Oceania), cujos resultados serão relatados à parte.

${ }^{433}$ Decreto no. 7.214 de 15 de Junho de 2010, artigo $3^{\circ}$, parágrafo $7^{\circ}$ : "O Ministério das Relações Exteriores e os demais órgãos envolvidos apresentarão anualmente, tendo como base a Ata
} 
demandas constantes da Ata está a de reforçar as visitas a presos brasileiros no exterior, definida como ação de caráter permanente. Todos os postos da rede consular possuem instruções permanentes de manter contato com os brasileiros presos em sua jurisdição e prestar-lhes a assistência necessária e cabível. Em havendo numerosa comunidade carcerária, os postos são estimulados a formar parcerias com voluntários da comunidade brasileira para a realização de visitas mais frequentes (Japão, por exemplo), nos países onde a legislação local permite tal prática. $^{434}$

O Ministério das Relações Exteriores, sob os auspícios da SGBE dispõe internamente do MANUAL DO SERVIÇO CONSUlar E JURídico ${ }^{435}$, cujo

Consolidada de demandas da comunidade, balanço das ações governamentais implementadas em benefício das comunidades brasileiras no exterior."

${ }^{434}$ III Conferência "Brasileiros no Mundo". Rio de Janeiro, 2 e 3 de dezembro de 2010. Ata Consolidada de Reivindicações das Comunidades Brasileiras no Exterior, p. 16. Ministério das Relações Exteriores Subsecretaria-Geral das Comunidades Brasileiras no Exterior. Departamento Consular e de Brasileiros no Exterior. Disponível online em: $<$ http://sistemas.mre.gov.br/kitweb/datafiles/BRMundo/pt-

br/file/Ata_Consolidada_III_CBM_dez_2010\%5B1\%5D\%5B1\%5D.pdf> (acesso em 03/03/2011). A Ata consiste na soma das reivindicações feitas pelos representantes de brasileiros presentes à I e à II Conferências "Brasileiros no Mundo". Conforme estabelecido no referido Decreto, será o roteiro para os órgãos públicos prestarem contas a respeito de suas ações que beneficiam os brasileiros no exterior. Poderá também incentivar e inspirar novas políticas. Trata-se de um documento dinâmico, pois poderá ser emendados mediante as discussões nas mesas temáticas e plenária das Conferências. Na tarde do dia 3/12 foram realizadas reuniões das quatro regiões geográficas que compõem o sistema de Conferências Brasileiros no Mundo (América do Sul e Central; América do Norte e Caribe; Europa; Ásia, África e Oceania), para examinar os resultados das mesas temáticas e discutir temas de interesse local, muitos dos quais já mencionados naquelas mesas. Todos os grupos contaram com a participação ativa dos Embaixadores e Cônsules nos respectivos países, o que muito contribuiu para a troca de experiências com os representantes da comunidade brasileira regional. A canditada ao título de Mestre participou da Mesa "América do Norte e Caribe", comentando sobre a importância do direito de informação sobre a assistência consular para preso estrangeiro, a partir da casuística internacional sobre a violação do artigo 36 da Convenção de Viena sobre Relações Consulares de 1963, tratada neste trabalho. O resultado foi um documento chamado "Relato dos Trabalhos", uma espécie de Relatório dos trabalhos, com as reveindicações colocadas em cada mesa, com propostas de alterações ao Manual do Serviço Consular e Jurídico. Entre as revindicações está a de "melhorar o acompanhamento dos brasileiros detidos, em especial aqueles para deportação". O documento está disponível online na Página do Portal "Brasileiros no Mundo" em: $<$ http://sistemas.mre.gov.br/kitweb/datafiles/BRMundo/ptbr/file/Relato\%20Mesas\%20Regionais.pdf> (acesso em 27/03/2011).

${ }^{435}$ República Federativa do Brasil. Ministério das Relações Exteriores. Subsecretaria-Geral das Comunidades Brasileiras no Exterior. Manual do Serviço Consular e Jurídico. Capítulo $3^{\circ}$. Assistência e Proteção a Brasileiros. Edição 2010. Esta candidata ao título de Mestre em Direito Internacional pela Faculdade de Direito da Universidade de São Paulo agradece imensamente ao apoio da Excelentíssima Senhora Secretária ADRIANA Telles RIBEIRO, Diplomata da Subsecretaria-Geral das Comunidades Brasileiras no Exterior, pelo gentilíssimo apoio e envio do Manual interno em fevereiro de 2011. Aproveita para agradecer pela sugestão de contatos com o Departamento de Assistência Consular do Ministério das Relações Exteriores - DAC. 
Capítulo $3^{\circ}$ dispõe sobre a prática do Itamaraty quanto à Assistência e Proteção a Brasileiros. Entre diversos aspectos, destacam-se as mais ligadas ao tema do direito de informação sobre assistência consular para preso estrangeiro. De acordo com a Seção $1^{\text {a }}$ do MANUAL, a Autoridade Consular zelará para que, dentro de sua jurisdição, os brasileiros possam gozar, plena e eficazmente, respeitada a legislação local e, no que for cabível, dos direitos previstos na Constituição Federal e demais normas legais do Brasil. O cônsul cuidará para que as autoridades locais ajam com equidade, justiça e civilidade em relação aos cidadãos brasileiros em Estados Receptores afora. Portanto, a situação do brasileiro perante as autoridades locais de imigração, como a irregularidade, não deverá diferenciar o seu atendimento. Os pedidos de pequenos auxílios financeiros serão examinados caso a caso pela autoridade consular e, verificado o caráter emergencial serão, extraordinariamente, concedidos aos brasileiros em estado de necessidade e em situação de desvalimento.

Quanto à efetivação do direito de defesa do brasileiro no exterior, consta no item 3.1.20 do MANUAL que "em casos excepcionais, a Autoridade Consular poderá submeter à Secretaria de Estado pedido de contratação de advogado para prestação de assistência jurídica, principalmente nos casos de falta de previsão da lei local para designação de defensor público ou de sérias dificuldades institucionais ou operacionais para a eficaz representação dos direitos do cidadão brasileiro local".

O item 3.1.24 da Seção $1^{\mathrm{a}}$ do Capítulo $3^{\mathrm{o}}$ do MANUAL trata exclusivamente do direito de informação sobre assistência consular para preso estrangeiro, ao determinar que ${ }^{436}$ :

Caberá igualmente à Autoridade Consular, no exercício do que lhe faculta o artigo 36 da Convenção de Viena sobre Relações Consulares: 1) prestar assistência aos brasileiros que se acharem envolvidos em processos criminais; 2) estabelecer contatos com autoridades de penitenciárias situadas em sua jurisdição e manter

\footnotetext{
${ }^{436}$ República Federativa do Brasil. Ministério das Relações Exteriores. Subsecretaria-Geral das Comunidades Brasileiras no Exterior. Manual do Serviço Consular e Jurídico. Capítulo $3^{\circ}$, Seção $1^{\text {a }}$ Página 4 de 6 . A Autoridade Consular não poderá ser parte ou procuradora em processos judiciais. No caso de cidadão brasileiro que seja considerado réu em quaisquer Tribunais ou Instâncias, deverá, todavia, quando oficialmente notificada, inteirar-se da natureza e peculiaridade do processo para comunicação à Secretaria de Estado.
} 
relação atualizada de presos brasileiros, bem como o andamento dos seus respectivos processos, remetendo à SERE/DAC, semestralmente, a respectiva relação; 3) caso solicitada, servir de ligação entre os prisioneiros e suas famílias, seja no Brasil ou no exterior; 4) nos postos onde é elevado o número de prisioneiros brasileiros, inteirar-se das condições de saúde e das instalações onde estejam detidos $e$, ainda, instruir servidor a visitar periodicamente os prisioneiros, mantendo fichário atualizado; e 5) assegurar, na medida do possível, aos brasileiros detidos ou encarcerados, acesso aos serviços consulares.

\section{A Seção 10 do Capítulo $3^{\circ}$ do Manual do Serviço Consular E} JURÍDICO trata exclusivamente do regulamento sobre Assistência e Proteção a Presos Brasileiros, e encontra fundamento jurídico nos artigos $5^{\circ}$ e $36^{\circ}$ da Convenção de Viena sobre Relações Consulares. A Autoridade Consular deverá elaborar e manter atualizada uma lista de presos brasileiros em sua jurisdição, com dados de qualificação civil do acusado, sua origem, pessoas de contato no Brasil e situação jurídica. Esses dados podem ser obtidos diretamente com o preso ou, indiretamente, com a autoridade penitenciária, apenas se o preso autorizar sua divulgação, e estabelecer um plano de visitas a instituições correcionais onde cidadãos brasileiros estejam cumprindo pena. O MANUAL estabelece também que sempre que oportuno, deverá ser relembrado às autoridades locais competentes o direito brasileiro provado de liberdade ser oficialmente informado de que poderá comunicar-se em curto prazo com a Autoridade Consular brasileira. E mais, caberá à Autoridade Consular indicar ao MRE eventual necessidade de aquisição, para detentos brasileiros, de itens, artigos ou produtos necessários à sua vida ou saúde (remédios, víveres não perecíveis, vestuário básico, artigos de higiene, agasalhos, material de leitura, etc). Onde houver demanda por esses itens, a Repartição Consular deverá estabelecer sua distribuição regular sempre que esta for permitida. ${ }^{437}$

\footnotetext{
${ }^{437}$ Por ocasião das visitas, periódicas e/ou eventuais, a Autoridade Consular procurará inteirar-se da situação jurídica do preso e fará breve relatório no qual inserirá os seguintes dados, que deverão ser mantidos em arquivo específico do Posto, para fins de consulta rápida quando requerido: 1) dados de qualificação civil; 2) delito(s) imputado(s); 3) especificações da pena restritiva de liberdade; 4) data prevista para a liberação; 5) se desempenha atividade laborativa no estabelecimento correcional; e 6) nome e número telefônico de contato do advogado ou defensor público. Manual do Serviço Consular e Jurídico. Capítulo $3^{\circ}$, Seção 10, item 3.10.4, p. 1. O Posto deverá acompanhar a evolução do processo criminal instaurado, sob a ótica estritamente consular.
} 


\section{CONCLUSÃo}

O interesse pelo estudo da casuística internacional referente à violação do direito de informação sobre assistência consular para preso estrangeiro, que ensejou a pesquisa da qual se originou este trabalaho, surgiu quando da realização de uma mesa de debates sobre o Caso AvEnA, ocorrida em 24 de setembro de 2008, no Salão Nobre da Faculdade de Direito da Universidade de São Paulo. Na ocasião, o Professor CELSO LAFER que, presidiu a mesa e palestrou justamente sobre a importância do tema, sobretudo para o Brasil. Em seguida, o advogado norteamericano Donald Francis Donovan, que representou o México perante a Corte Internacional de Justiça, comentou sobre os obstáculos de direito interno argüidos pelo governo norte-americano para não aplicação das decisões da Corte, em desafio às suas obrigações de Direito Internacional.

Por último, FRANCISCO ReZEK, Juiz da Corte Internacional de Justiça relatou a sua experiência pessoal na apreciação do caso BREARD e LAGRAND, como a reação dos juízes que, até o caso apresentado pelo Paraguai, jamais haviam se voltado para a importância da matéria em debate. Ele comentou ainda que, no julgamento do caso LAGRAND, os juízes permaneceram reunidos durante dias, discutindo se a assistência consular estaria presente no corpus juris dos direitos humanos.

O tema escolhido é de transcendental importância, sobretudo diante do mundo globalizado em que a migração é um fenômeno relevante. Tanto a Corte Internacional de Justiça quanto a Corte Interamericana de Direitos Humanos interpretaram que o direito de informação e notificação sobre assistência consular ao preso estrangeiro não pode mais ser considerado puramente instituidor de obrigações inter-estatais.. No exterior, esses estrangeiros são submetidos às mesmas leis que os nacionais e não podem ser discriminados. No entanto, ao se depararem com situações adversas, como a privação da liberdade, caso não sejam bem assistidos, correm o risco de sofrer discriminação no decorrer de um processo criminal desigual e injusto. 
É aqui que se apresenta uma das funções do da Autoridade Consular, senão a primordial, a de prestar assistência a seus nacionais, no caso, quando privados de liberdade no Estado Receptor, e por qualquer motivo. É exatamente esse o direito que está disposto pelo artigo 36 da Convenção de Viena sobre Relações Consulares de 1963, e que protege o indivíduo em duas vertentes: permite o acesso do preso, se ele não recusar, aos representantes consulares de seu país; e, por outro lado, permite que o Estado que envia seja notificado pelo Estado Receptor quanto à prisão de seu súdito, desde que ele não rejeite expressamente.

Com efeito, o estrangeiro quando se vê privado de liberdade, diante da sua peculiar situação de vulnerabilidade, deve contar com medidas que lhe permitam um verdadeiro e pleno acesso à justiça. Não basta que a lei lhe reconheça os mesmos direitos que os demais indivíduos nacionais do Estado em que se encontra preso, mas deve comparecer em pé de igualdade perante a justiça, sem as graves limitações que implicam a estranheza cultural, a ignorância do idioma, o desconhecimento do sistema processual e outras restrições de suas possibilidades de defesa. São necessárias "vias de compensação" que lhe garantam o pleno acesso à justiça, e conteúdo real ao devido processo legal. ${ }^{438} \mathrm{~A}$ assistência consular é um direito essencial para que o indivíduo, nessa situação, possa exercer a sua defesa de forma ampla.

A pesquisa envolveu vertentes que não implicam questões puramente de Direito Internacional Público, mas também o estudo dos efeitos da casuística internacional estudada na Parte II no Direito brasileiro, nominalmente no processo penal. O estudo dos casos levantou a discussão contemporânea sobre o destaque da pessoa humana em foro internacional que tradicionalmente é competente para julgar litígios entre Estados, com relação a todas as questões de Direito Internacional que as partes a submetam, e a todos os assuntos especialmente previstos na Carta das Nações Unidas ou nos tratados vigentes. ${ }^{439}$ Ainda que a capacidade postulatória condicionada à intervenção de agente que lhe assegure a representação seja pelo

\footnotetext{
${ }^{438}$ Opinión Consultiva OC-16/99 del 1 de octubre de 1999. El Derecho a la Información sobre la Asistencia Consular en el Marco de las Garantías del Debido Proceso Legal, Voto concordante do JUIZ SÉRGIO GARCIA RAMIREZ, pp. 02 e 03.

${ }^{439}$ Arts. 34 e 36 do Estatuto da Corte Internacional de Justiça.
} 
instituto da proteção diplomática, trata-se de direito do Estado e sua interdependência com o indíduo, isto é, de um lado o direito do Estado de proteger seu próprio interesse em proteger seu súdito, diplomática e consularmente, em território estrangeiro; de outro, o direito do indivíduo, enquanto estrangeiro, de usufruir o direito de assistência consular.

O desafio teórico proposto foi questionar quais seriam os efeitos das decisões internacionais sobre os Estados que, muito embora façam parte do tratado em litígio, não participaram da controvérsia internacional isto é, se poderiam esses Estados terceiros ao litígio aplicar internamente entendimento diverso ao da CIJ. Isso porque, embora as decisões dos casos LAGRAND e AVENA não sirvam como evidência de uma regra geral de Direito Internacional, as decisões da Corte representam um passo incremental na evolução do Direito Internacional, no sentido de invocar um tratado que estabelece direitos de proteção do indivíduo, desenvolvendo novas formas de os indivíduos fazerem valer os seus direitos tanto perante os tribunais internos quanto internacionalmente, inclusive perante a Corte Internacional de Justiça, por meio do instituto da proteção diplomática. ${ }^{440}$

A partir da apreciação dos casos julgados pela Corte Internacional de Justiça, BreArd, LAGRAnd e AvenA; assim como da Opinião Consultiva n. ${ }^{0} 16$ de 01 de outubro de 1999, emitida pela Corte Interamericana de Direitos Humanos, ambos os tribunais tiveram a oportunidade histórica de interpretar e regulamentar o direito de informação e notificação sobre assistência consular para preso estrangeiro. A casuística internacional representa uma grande contribuição para o aprimoramento e avanço da assistência consular para o preso estrangeiro, porque indica a forma como esse direito deve ser aplicado tanto perante o Estado Receptor, mas principalmente, perante o indivíduo. Ademais das conseqüências diretas no plano jurídico-processual interno dos Estados partes da Convenção, porque o Estado receptor não pode aplicar doutrinas de direito interno para fundamentar o não cumprimento da obrigação internacional.

\footnotetext{
${ }^{440}$ MurPhy, Sean D. Does International Law obligate States to open their national courts to persons for the invocation of treaty norms that protect or benefit persons?, p. 09.
} 
Basicamente, pelo estudo da casuística, destacam-se os seguintes principais pontos: 1) a condenação dos Estados Unidos à revisão e reconsideração das sentenças de morte; haja vista a violação da obrigação internacional de informar os réus estrangeiros sobre seus direitos previstos pelo artigo 36 da Convenção de Viena de 1963 ; 2) a interpretação da expressão "sem tardar", do artigo 36.1(b) da Convenção de Viena - a Corte decidiu que o Estado receptor deve informar o indivíduo assim que puder perceber tratar-se de estrangeiro, ou assim que houver indícios para pensar que não se trata de um nacional; precisamente, o exato momento poderá variar de acordo com as circunstâncias, assim que possível constatar-se que se trata de um estrangeiro; 3) a interdependência entre os direitos individuais do preso estrangeiro e os do Estado que envia; 4) o Estado Receptor não pode usar de doutrinas de direito interno para não cumprimento da obrigação internacional de informar o estrangeiro privado de liberdade em seu território do direito que ele tem de entrar em contato com seu Consulado; 5) o direito de informação sobre assistência consular para o preso estrangeiro, a partir da interpretação evolutiva dos tratados internacionais em matéria diplomática, e do impacto exercido pelo Direito Internacional dos Direitos Humanos, compõe o corpus iuris dos direitos humanos no que diz respeito às garantias mínimas do devido processo legal, quanto à efetivação do direito fundamental à ampla defesa do acusado estrangeiro.

Celebrada em Viena, em 24 de abril de 1963, a Convenção de Viena sobre Relações Consulares foi assinada pelo Brasil na mesma data. Aprovada pelo Congresso por força do Decreto Legislativo n. ${ }^{\circ} 9$ de 1967, foi ratificada e promulgada pelo Presidente da República, havendo sido incorporada ao ordenamento jurídico interno brasileiro por força do Decreto 61.078, de 26 de julho de 1967, publicada no Diário Oficial de 28 de julho de 1967. Assim sendo, as provisões da Convenção fazem parte do Direito brasileiro, sendo fonte soberana de direito público, de plena e irrestrita vigência. Suas disposições têm, portanto, validade e executoriedade no território nacional. Todavia, o Brasil não ratificou o Protocolo Opcional à Convenção de Viena de 1963, que permite a intervenção da Corte 
Internacional de Justiça, já que a reconhece como foro competente para julgar questões referentes à interpretação e aplicação desse tratado. ${ }^{441}$

É nesse contexto que se debate se as sentenças e medidas provisórias da Corte Internacional de Justiça teriam algum efeito com relação a terceiros Estados que são partes do tratado envolvendo a controvérsia, mas que não participam do litígio. No caso do Brasil, sugere-se que seria este um efeito análogo ao das Opiniões Consultivas da Corte Interamericana de Direitos Humanos, cuja função é interpretar normas jurídicas internacionais, fixando o seu alcance e conteúdo, mesmo na ausência de casos contenciosos, possibilitando uma maior certeza jurídica aos sujeitos de Direito Internacional $^{442}$. Desde que promulgou a aderência à Convenção Americana de Direitos Humanos, pelo Decreto n. ${ }^{\circ}$ 678, de 06 de novembro de 1992, o Brasil aceitou a jurisdição consultiva da Corte Interamenticana.

A partir da interpretação dada pelo Supremo Tribunal Federal concluise que, no Direito brasileiro, a Constituição Federal prevalece sobre quaisquer tratados internacionais aos que o País se encontre vinculado, incluídos os de proteção aos direitos humanos que não foram recepcionados na forma como exige o $\S 3^{\circ}$ do artigo $5^{\circ}$ da Constituição, introduzido pela Emenda Constitucional 45/2004.

Considerando o entendimento jurisprudencial do Supremo Tribunal Federal, a Convenção de Viena de 1963 tem validade e executoriedade no território nacional com o igual status de lei ordinária, por não ser tratado internacional tradicionalmente de direitos humanos. Assim, sequer recebe o tratamento diferenciado da supralegalidade, como recebem os que foram incorporados pelo Brasil anteriormente à Emenda Constitucional n. ${ }^{\circ}$ 45/2004. No entanto, a Corte Interamericana de Direitos Humanos, a partir de uma interpretação evolutiva do Direito Internacional Público, decidiu pelo impacto direto exercido pela dinâmica do

\footnotetext{
$441 \mathrm{O}$ art. $1^{\circ}$ do Protocolo Facultativo à CVRC sobre Solução Compulsória de Controvérsias, estabelece que "litígios decorrentes da interpretação ou aplicação da Convenção devem estar dentro da jurisdição obrigatória da Corte Internacional de Justiça e, consequentemente, pode ser interposto perante o Tribunal de Justiça um pedido feito por qualquer das partes em litígio seja Parte do presente Protocolo".

${ }_{442}$ RAMOS, André de Carvalho. Direitos Humanos em Juízo, pp. 341 e 342.
} 
Direito Internacional dos Direitos Humanos sobre o artigo 36 da Convenção. ${ }^{443}$ É nesse contexto que se sugeriu nesta Dissertação que o direito de informação sobre assistência consular para preso estrangeiro deve ser, no Direito brasileiro, interpretado da forma como o fez a Corte Interamericana, considerado-o como componente do rol das garantias processuais-constitucionais, com fundamento tanto no inciso LXIII como no $\S 2^{\circ}$, ambos do artigo $5^{\circ}$ da Constituição Federal. Consequentemente, a não efetivação do direito pode acarretar uma nulidade processual penal absoluta, uma vez demonstrado o prejuízo ao direito de defesa desse estrangeiro.

O inciso LV do artigo $5^{\circ}$ da Constituição Federal garante, como direito fundamental que é, que, "aos litigantes, em processo judicial ou administrativo, e aos acusados em geral são assegurados o contraditório e ampla defesa, com os meios e recursos a ela inerentes". O dispositivo, embora não mencione explicitamente os acusados estrangeiros, sugere-se neste trabalho que o termo "em geral" também os inclui. Já o inciso LXIII do mesmo dispositivo estabelece os direitos do preso: "o preso será informado de seus direitos, entre os quais o de permanecer calado, sendo-lhe assegurada a assistência da família e de advogado." Pela leitura do dispositivo, pela expressão "entre os quais" é possível argumentar que não se tratam de direitos estáticos do preso, que se limitam ao direito ao silêncio, à assistência da família e a um advogado. É pela interpretação dos presentes dispositivos, e pela expressão "entre os quais", que se entende incluído o direito de o estrangeiro ser informado de que tem direito de comunicar-se com o seu Consulado, na forma como interpretada pela Opinião Consultiva n. ${ }^{\circ} 16$ da Corte Interamericana de Direitos Humanos, a cuja jurisdição o Brasil se submete.

A Convenção Americana de Direitos Humanos está em vigor no ordenamento jurídico interno brasileiro e, conforme entendimento do Supremo Tribunal Federal, com hierarquia supralegal, ou seja, estando abaixo da Constituição, porém acima da legislação interna. Esse status normativo supralegal dos tratados internacionais de direitos humanos em vigor no Brasil, torna inaplicável

\footnotetext{
${ }^{443}$ Opinión Consultiva OC-16/99 del 1 de octubre de 1999. El Derecho a la Información sobre la Asistencia Consular en el Marco de las Garantías del Debido Proceso Legal, Voto concordante do Juiz CANÇADO TRINDADE, $§ 13$.
} 
a legislação infraconstitucional com ele conflitante, seja ela anterior ou posterior ao ato de ratificação, sendo fundamento de validade o $\S 2^{\circ}$ do artigo $5^{\circ}$ da Constituição de 1988. E tendo o Brasil reconhecido a jurisdição compulsória da Corte Interamericana de Direitos Humanos, é imperioso respeitar as interpretações dadas por meio das Opiniões Consultivas, devendo ser conhecidas e utilizadas pelos operadores jurídicos brasileiros. Atuando assim, em conformidade com a interpretação da Corte Interamericana, a qual se submete, o Brasil evita eventual futura responsabilização internacional por violação da Convenção Americana sobre Direitos Humanos. ${ }^{444}$

É nesse contexto, de estar sujeito à jurisdição compulsória da Corte Interamericana, que o Brasil poderia sofrer uma acusação de violação de um direito ou liberdade protegido no marco do artigo 64.1 do Pacto de São José, no sentido de entender-se que o direito de assistência consular para preso estrangeiro, estabelecido pelo art. 36 da Convenção de Viena sobre Relações Consulares de 1963 contem disposições concernentes à proteção de direitos humanos nos Estados Americanos. $\mathrm{O}$ caso de estrangeiros aqui presos, sem que o Brasil, como Estado Receptor, tenha garantido-lhes, efetivamente e oportunamente, o direito deles de informação e acesso ao Consulado de sua nacionalidade, pode ser levado à Comissão Interamericana de Direitos Humanos, que pode acionar a Corte Interamericana. O Brasil corre o risco

\footnotetext{
${ }^{444}$ Cita-se apenas um dos diversos exemplos de jurisprudência do Supremo Tribunal Federal que trata da hierarquia especial do Pacto de São José no Direito brasileiro. "Direito Processual. Habeas Corpus. Prisão Civil do Depositário Infiel. Pacto de São José da Costa Rica. alteração de orientação da jurisprudência do STF. concessão da ordem. 1. A matéria em julgamento neste habeas corpus envolve a temática da (in)admissibilidade da prisão civil do depositário infiel no ordenamento jurídico brasileiro no período posterior ao ingresso do Pacto de São José da Costa Rica no direito nacional. 2. Há o caráter especial do Pacto Internacional dos Direitos Civis Políticos (artigo 11) e da Convenção Americana sobre Direitos Humanos - Pacto de San José da Costa Rica (artigo $7^{\circ}, 7$ ), ratificados, sem reserva, pelo Brasil, no ano de 1992. A esses diplomas internacionais sobre direitos humanos é reservado o lugar específico no ordenamento jurídico, estando abaixo da Constituição, porém acima da legislação interna. O status normativo supralegal dos tratados internacionais de direitos humanos subscritos pelo Brasil, torna inaplicável a legislação infraconstitucional com ele conflitante, seja ela anterior ou posterior ao ato de ratificação. 3. Na atualidade a única hipótese de prisão civil, no Direito brasileiro, é a do devedor de alimentos. $O$ artigo $5^{\circ}, \S 2^{\circ}$, da Carta Magna, expressamente estabeleceu que os direitos e garantias expressos no caput do mesmo dispositivo não excluem outros decorrentes do regime dos princípios por ela adotados, ou dos tratados internacionais em que a República Federativa do Brasil seja parte. O Pacto de São José da Costa Rica, entendido como um tratado internacional em matéria de direitos humanos, expressamente, só admite, no seu bojo, a possibilidade de prisão civil do devedor de alimentos e, conseqüentemente, não admite mais a possibilidade de prisão civil do depositário infiel. 4. Habeas corpus concedido. HC 94702/GO Goiás. Relatora: Min. Ellen Gracie. Julgamento: 07/10/2008. Órgão Julgador: Segunda Turma. Supremo Tribunal Federal."
} 
de ser responsabilizado pela Corte Interamericana de Direitos Humanos caso atuar internamente ao contrário dos moldes da Opinião Consultiva n. ${ }^{\circ} 16$ de 01 de outubro de 1999.

Constatou-se ainda que o estudo dos casos reflete uma mudança de perspectiva na Corte Internacional de Justiça, embora muito tímida. Nas decisões dos casos LAGRAND e AVENA, a Corte, por meio da interpretação literal do artigo 36 da Convenção de Viena sobre Relações Consulares de 1963, reconheceu a existência de uma "circunstância especial de interdependência" entre direito individuais e direitos do Estado que envia. ${ }^{445}$ Sugeriu-se que tímido destaque do indivíduo em foro internacional tradicionalmente inter-Estatal, poderia ser uma aparente e discutível resistência ao voluntarismo positivista Westphaliano, que nega o jus standi aos indivíduos, dificultando a própria compreensão do Direito Internacional como um sistema verdadeiramente universal que deveria ser". 446

A concepção essencialmente universalista dos chamados "pais fundadores" do Direito Internacional dos séculos XVI e XVII (FrANCISCO DE Vitoria, Francisco Suárez, Alberto Gentili, hugo Grotius, C. Byunkershoek, SAMuel Pufendorf, CRistian WolfF e outros), baseava-se em uma série de princípios transcendentais como justiça, identificados pelo uso da razão, e pela noção de que toda atividade humana estaria vinculada a uma moralidade global. Foi submetida à emergência do positivismo jurídico, que personificou o Estado dotando-o de vontade própria. ${ }^{447} \mathrm{O}$ papel dos princípios gerais, que

445 "The Court would recall that, in the LaGrand case, it recognized that "Article 36, paragraph 1 [of the Vienna Convention], creates individual rights [for the national concerned], which . . may be invoked in this Court by the national State of the detained person" (I.C.J. Reports 2001, p. 494, para. 77). It would further observe that violations of the rights of the individual under Article 36 may entail a violation of the rights of the sending State, and that violations of the rights of the latter may entail a violation of the rights of the individual. In these special circumstances of interdependence of the rights of the State and of individual rights, Mexico may, in submitting a claim in its own name, request the Court to rule on the violation of rights which it claims to have suffered both directly and through the violation of individual rights conferred on Mexican nationals under Article 36, paragraph 1 (b)." Case concerning Avena and other Mexican nationals (Mexico v. United States of America), ICJ Reports of Judgments, Advisory Opinions and Orders (05/02/2003), parágrafo 40.

446 CANÇADO TRINDADE, Antônio Augusto. Tratado de Direito Internacional dos Direitos Humanos, pp. 447-448 e 453.

${ }^{447}$ O filósofo, diplomata e jurista suíço, EMERICH DE VATTEL, cuja principal obra, O Direito das Nações é de 1758, é uma figura fundamental nessa mudança em relação ao positivismo. Enquanto mantinha muitos aspectos do pensamento naturalista, ele enfatizou o poder e a autoridade do soberano de uma medida que suscitou dúvidas quanto ao fato de que o Direito Internacional jamais 
fundamentam qualquer sistema jurídico, e conformam suas normas na busca da realização da justiça, foi minimizado. Tratados e costumes passam a ser considerados como sendo a expressão primordial da vontade dos Estados.

Esse sistema positivista-voluntarista perdurou como premissa básica do sistema jurídico internacional, desde a época do colonialismo europeu até a paz de Versalhes, que celebrou o final da Segunda Guerra Mundial. A instauração da Liga das Nações, em 28 de junho de 1919, marcou a entrada do sistema internacional contemporâneo. $^{448}$ Ocorre uma mutação qualitativa do Direito Internacional do patamar da coexistência para a cooperação. Doravante, se fazem presentes e atuantes outros agentes além dos Estados - que permanecem atuando como protagonistas da cena internacional - e das organizações internacionais. Passam a ter voz os indivíduos, organizações não-governamentais, e demais entidades da sociedade, estes não como atores políticos de Direito Internacional, no sentido de que não firmam tratados, mas possuem importante papel no processo tanto de formação quanto de aplicação das normas internacionais, o que favorece a multiplicidade, fragmentação e aparente desconexão entre os atores desse sistema internacional, ao mesmo tempo, necessários para a realização de convivência ordenada.

Nesse avanço e tímida mudança de paradigma, é de se comentar uma das discussões atuais no seio da Comissão de Direito Internacional das Nações Unidas, concernente à proliferação de tribunais internaiconais, criados para atender o Direito Internacional contemporâneo e suas especialidades. Discute-se se essa multiplicação, ou "fragmentação", prejudicaria, ou ameaçaria, a coerência do sistema jurídico internaiconal, ou até mesmo se causaria conflitos entre decisões, o que resultou em um comentado Relatório. ${ }^{449} \mathrm{E}$ isso foi visto no estudo, eis que a Corte Internacional de Justiça e a Corte Interamericana de Direitos Humanos fazem suas

poderia vincular o soberano. Destacam-se também os filósofos políticos THOMMAS HoBBES e JEAN Bodin, e os ingleses JoHn AUSTIN e JEREMY BENTHAN. ANGHIE, Antony. Imperialism, sovereignty and the making of International Law, p. 42.

${ }^{448}$ CASELlA, Paulo Borba. Fundamentos do Direito Internacional Pós-Moderno, p. 57 e 1364.

${ }^{449}$ KoskenniEmI, Martti (finalization). Fragmentation of International Law: Difficulties Arising from the Diversification and Expansion of International Law. Report of the Study Group of the International Law Commission. United Nations General Assembly A/CN.4/L.682. 13 April 2006. 
constatações sobre o mesmo dispositivo do mesmo tratado, cada foro com com seu ponto de vista marcante, sendo o primeiro mais relutante.

Essa "fragmentação", ou proliferação, e o aumento do número de sujeitos internacionais caracterizam o tempo histórico e contexto cultural que se denomina pós-moderno. O quadro normativo e institucional, que existe há séculos, tornou-se consideravelmente mais extenso (pelo aumento do número de participantes), e mais complexo (pela multiplicação da presença e da influência de todo o conjunto de atores e agentes não estatais no sistema internacional). Daí depende a consciência e a convicção da juridicidade para assegurar grau adequado de implementação e aplicação dos sistemas institucionais e normativos, mediante a positivação de usos e costumes, consolidando-se novos patamares de juridicidade. ${ }^{450}$

Ao contrário do que se sucede com as comunidades nacionais organizadas na forma de Estados, o sistema internaiconal é ainda hoje descentralizado, e o será provavelmente por muito tempo. No plano internacional não existe autoridade superior nem milícia permanente. A organização em Estados é horizontal, e estes procedem de acordo com normas jurídicas internacionais " $n a$ medida em que tenham sido objeto de seu consentimento". São os destinatários que criam as normas. Ao contrário de como acontece com os parlamentos nacionais, que ouvem a voz dos povos, não existe representação ou subordinação, mas a convivência organizada baseia-se na coordenação. $\mathrm{O}$ Estado não é internacionalmente jurisdicionável perante corte alguma. É o consentimento do Estado que convalida a autoridade de um foro judiciário ou arbitral, tornando a sentença obrigatória, e que eventual descumprimento resulte em responsabilização internacional, embora sequer exista um sistema internacional de sanções, de execução de sentenças internacionais. ${ }^{451}$

O fato é que as decisões da Corte Internacional de Justiça são as mais significativas quando tratam do Direito Internacional Geral, em suas decisões e pareceres consultivos geralmente bem fundamentados. Os pontos de vista da Corte

\footnotetext{
${ }^{450}$ O professor PAULO CASELLA explica a importância do sistema normativo internacional efetivo, com relação aos planos internos dos Estados, porque sem a atuação ou omissão destes, nem haveria sistema internacional, por mais precário que seja. In: CASELla, Paulo Borba. Fundamentos do Direito Internacional Pós-Moderno, pp. 18-19, 26, 31.

${ }^{451}$ REZEK, Francisco. Direito Internacional. Curso Elementar, pp. 2-3.
} 
Internacional de Justiça sobre o Direito Internacional Geral continuará a ter influência que ultrapassa sua jurisdição nominal. E isso é verdade, muito embora o tribunal judicial das Nações Unidas não tenha sido dotado pela comunidade internacional com o status de "Suprema Corte de Direito Internacional", com autoridade universal de revisão. Mesmo assim, a Corte Internacional de Justiça tem um papel importante a desempenhar na manutenção da coerência da interpretação do Direito Internacional Geral - uma função valiosa. ${ }^{452}$

A dinâmica da sociedade internacional contemporânea tem desafiado o entendimento clássico positivista-voluntarista, de que o Direito Internacional é fruto e estaria submetido exclusivamente à livre-vontade dos Estados, em prejuízo de outros atores. Gradativamente passa a voltar-se para a gradual identificação e realização de valores, objetivos e metas comuns superiores e universais, que ultrapassam a condição do consentimento, para enfrentar o que é juridicamente necessário, como a proteção do ser humano e do meio ambiente, desarmamento nuclear, terrorismo, erradicação das discriminações, da pobreza e das disparidades entre os Estados, a busca do desenvolvimento humano, auto-determinação dos povos, entre outros - tudo para assegurar a própria sobrevivência da humanidade. É dessa forma que o Direito Internacional evolui, se expande, se aperfeiçoa e se fortalece e, por fim, se legitima.

\footnotetext{
452 CHARneY, Jonathan I. The impact on the international legal system of the growth of international courts and tribunals. Materials and Publications. NYU Journal of International Law and Politics, Vol. 31, p. 705 . Disponível online em: <http://www.pictpcti.org/publications/PICT_articles/JILP/Charney.pdf> (acesso em 29/09/2010).

452 ChARneY, Jonathan I. The impact on the international legal system of the growth of international courts and tribunals. Materials and Publications. NYU Journal of International Law and Politics, Vol. 31, p. 702. Disponível online em: <http://www.pictpcti.org/publications/PICT_articles/JILP/Charney.pdf> (acesso em 29/09/2010).
} 


\section{BIBLIOGRAFIA}

\section{A) Bibliografia Específica}

I CONFERÊNCIA SOBRE AS COMUNIDADES BRASILEIRAS NO EXTERIOR. Brasileiros no Mundo. Palácio Itamaraty do Rio de Janeiro, em 17 e 18 de julho de 2008. Subsecretaria Geral das Comunidades Brasileiras no Exterior (SGEB), do Ministério das Relações Exteriores, em parceria com a Fundação Alexandre de Gusmão, 2009. Manual de Direito Internacional Público. 16 ${ }^{\mathrm{a}}$ Ed., rev., atual., e ampl. São Paulo: Saraiva, 2008.

CARTER, Linda E. Compliance with ICJ Provisional Measures and the Meaning of Review and Reconsideration under the Vienna Convention on Consular Relations: Avena and other Mexican National Nationals (Mex. V. U.S.). Michigan Journal of International Law. Vol. 25:117, pp. 117-134, 2003-2004.

BuYs, Cindy Galway. Strangers in a Strange Land: The Importance of Better Compliance with Consular Notification Rights. Southern Illinois University School of Law. July 30, 2010.

CERnA, Christina Monica. The Right to Consular Notification as a Human Right. For the Medellin Symposium. Suffolk Transnational Law Review. Vol. 31, nr. 2, (2008), pp. 419 - 469.

Correia DE Brito, Wladimir Augusto. Direito Consular. Coimbra, Protugal. Coimbra Editora. 2004.

DJAJIC, Sanja. The Effect of International Court of Justice Decisions on Municipal Courts in the United States: Breard v. Greene. 23 Hastings Int'l \& Comp. L. Rev. 27 (1999).

Dolinger, Jacob. Os Estados Unidos perante o Direito Internacional. A decadência jurídica de uma grande nação. Estudos em homenagem ao Professor Celso D. Albuquerque Mello. In: DiREITo, Carlos Alberto; Cançado Trindade, A. A.; Pereira, Antônio Celso. (Orgs). Novas Perspectivas do Direito Internacional Contemporâneo. São Paulo: Renovar.

ElizOndo, Gonzalo e CASAFOnT, Paola. Migración y dinâmica de los derechos humanos hoy. In: Os Rumos do Direito Internacional dos Direitos Humanos. Ensaios em Homenagem ao Professor Antônio Augusto Cançado Trindade. Liber Amicorum Cançado Trindade. Tomo III. Porto Alegre: Sergio Antonio Fabris Editor. 2005. 
Fernandes, Antonio Scarance. A Reação Defensiva à Imputação, São Paulo: Revista dos Tribunais, 2002.

Processo Penal Constitucional. $5^{\text {a }}$ Ed. São Paulo: Revista dos Tribunais, 2007.

Fernandes, Antonio Scarance; AlmeIdA, José Raul Gavião de; Moraes, Maurício Zanoide de. Sigilo no Processo Penal: Eficiência e Garantismo. São Paulo: Revista dos Tribunais, 2008.

Ferrajoli, Luigi. Direito e Razão: Teoria do Garantismo Penal. São Paulo: Ed. Revista dos Tribunais, 2006.

FitZPATRICK, Joan e outros. Consular rights and the death penalty after LaGrand. American Society of International Law. Proceedings of the Annual Meeting; 2002; ABI/INFORM Global, pp. 309-319.

GonÇAlves, João Batista. O devido processo legal e o pacto de São José da Costa Rica. Tese de Doutorado defendida sob a orientação da Prof. Dra. Maria Sylvia Zanella Di Pietro. Faculdade de Direito da Universidade de São Paulo, 1999.

Grinover, Ada Pellegrini, Gomes FiLho, Antonio Magalhães, Fernandes, Antonio Scarance. As Nulidades no Processo Penal. $11^{\text {a }}$ Ed, São Paulo: Revista dos Tribunais, 2009.

Garantias processuais na cooperação internacional em matéria penal. In. BAPTISTA, Luiz Olavo; FONSECA, José Roberto Franco da, coords. O direito internacional no terceiro milênio: estudos em homenagem a Vicente Marotta Rangel São Paulo: LTr, 1998.

Gomes FilHo, Antônio Magalhães. Garantias Processuais nos recursos criminais. São Paulo Atlas 2002

HOPPE, Carsten. Implementation of LaGrand and Avena in Germany and the United States: Exploring a Transatlantic Divide in Search of a Uniform Interpretation of Consular Rights. The European Journal of International Law, Vol. 18 no. 2, 2007.

JAMES, Anne e Joanne Cecil. Equal Protection: Consular Assistance and Criminal Justice Procedures in the USA. An Introductory Guide for Consulates, The International Justice Project, Second Edition, 2005.

Jimenez Piernas, Carlos B. Protección consular y diplomática del ciudadano de la Unión Europea. Madrid: Instituto Estudios Politicos, pp. 9-51, 1993.

LeE, Luke T. J.D. and Quigley, John. Consular Law and Practice. Third Edition. Oxford University Press, 2008.

Manual do Serviço Consular e Jurídico. República Federativa do Brasil. Ministério das Relações Exteriores. Subsecretaria-Geral das 
Comunidades Brasileiras no Exterior. Capítulo $3^{\circ}$. Assistência e Proteção a Brasileiros. Brasília. Edição 2010.

MARESCA, Adolfo. Las relaciones consulares. Madrid: Tolle, Lege Aguilar, 1974.

Mon, Christopher J. Le. Post-Avena Application of the Vienna Convention on Consular Relations by United States Courts. Leiden Journal of International Law, Vol. 18, No. 2, pp. 215-235, 2005

Moraes, Alexandre de. Constituição do Brasil Interpretada e legislação constitucional. $7^{\mathrm{a}}$ Ed. São Paulo: Atlas, 2007.

Nascimento e Silva, G. E. de. Diplomacia e Protocolo. Rio de Janeiro: Gráfica Record, 1969.

NuCCI, Guilherme de Souza. Código de Processo Penal Comentado. $8^{a}$ ed. São Paulo: Revista dos Tribunais, 2008.

PARRY, John T. Congress, the supremacy clause, and the implementation of treaties. Fordham International Law Journal. Vol. 32, n. ${ }^{\circ}$ 4, 2008-2009, pp. 1209-1335.

PeñAlVer, Aurélio Blanco. Derecho de asistencia consular e información. In: CORAL Arangüena, Fanego. Garantías procesales en los procesos penales en la Unión Europea. Procedural safeguards in Criminal Proceedings throughout the European Union. 2007, ISBN 978-84-8406765-8 , pags. 345-354.

PERruChOud, Richard. Consular protection and assistance. In: CHOLEWINSKI, Richard. International Migration Law: Developing Paradigms and Key Challenges. Cambridge University Press. 2007.

RAMíREZ, Sergio García. Derechos Humanos y Justicia Penal. Los Reformadores. LEÃO, Renato Zerbini Ribeiro (Coordenador), e outros. Os Rumos do Direito Internacional dos Direitos Humanos. Ensaios em Homenagem ao Professor Antônio Augusto Cançado Trindade. Liber Amicorum Cançado Trindade. Tomo III. Porto Alegre: Sergio Antonio Fabris Editor. 2005.

RAY, Sarah M. Domesticating International Obligations: How to Ensure U.S. Compliance with the Vienna Convention on Consular Relations. California Law Review, 91, 2003, pp. 1729- 1772.

SHEIK, Mani. From Breard to Medellin: Supreme Court Inaction or ICJ Activism in the Field of International Law?, 94 California Law Review, (March, 2006), 531-574.

SiLveIRA, Paulo Fernando. Devido processo legal - Due process of Law. Belo Horizonte: Del Rey, 1996. 
SOARES, Guido Fernando Silva. Os direitos humanos e a proteção dos estrangeiros. Revista de Informação Legislativa Brasília, v. 41, n. 162, p. 169-204, abr./jun. 2004.

SouZA, Artur de Brito Gueiros. O preso estrangeiro no Brasil: aspectos jurídicos e criminológicos. 1 ed. Rio de Janeiro: Lumen Iuris Editora, 2007.

TAMS, Christian J. Consular Assistance: Rights, Remedies and Responsibility. Comments o $n$ the ICJ's Judgement in the LaGrand case. Vol. 13, No. 5, 1257-1259. European Journal of International Law. 2002.

Tranel, Adrienne M. The Ruling of the International Court of Justice in Avena and other Mexican Nationals. American University International Law Review, vol. 20, 2004, pp. 403-464.

ThIRlway, Hugh. Concepts, principles, rules and analogies: international and municipal legal reasoning". Recueil des cours, vol. 294, pp. 265-405, 2002.

VAsquez, Carlos Manuel. Breard, Printz, and the Treaty Power. University of Colorado Law Review, Vol. 70, pp. 1317-1360, 1999.

B) Bibliografia Complementar

AgO, Roberto. The First International Communities in the Mediterranean World, British Yearbook of International Law 53:213, 1982.

ANGHIE, Antony. Imperialism, sovereignty and the making of International Law. Cambridge: Cambridge University Press, 2004. 378pp.

ARAÚJO, Nadia de. Direito internacional privado: teoria e prática brasileira. 3 . Ed. Rio de Janeiro: Renovar, 2006.

A influência das Opiniões Consultivas da Corte Interamericana de Direitos Humanos no ordenamento jurídico brasileiro. Revista da Faculdade de Direito de Campos, Ano VI, No 6 - Junho de 2005. Disponível online em: $<$ http://www.fdc.br/Arquivos/Mestrado/Revistas/Revista06/Docente/09.p df $>$.

BARroso, Luís Roberto. Interpretação e aplicação da Constituição. São Paulo: Saraiva, 1996.

BROWNLIE, Ian. International Law at the Fiftieth Anniversary of the United Nations. General Course on Public International Law. Hague Academy 
of International Law. Recueil des Cours de l'Academie de Droit International de la Haye. Volume 255 (1995), pp. 9-228.

Principles of Public International Law. Seventh Edition. Oxford University Press, 2008.

CAnÇAdo Trindade, Antônio Augusto. Direito Internacional em um mundo em transformação. A determinação do surgimento da responsabilidade internacional dos Estados. São Paulo: Renovar, 2002, pp. 371 - 408.

International Law for Humankind: towards a new Jus Gentium (I). General Course on Public International Law. Hague Academy of International Law. Recueil des Cours de l'Academie de Droit International de la Haye, Volume 316 (2005), pp. 9-439.

International law for humankind: towards a new Jus Gentium (II). General Course on Public International Law. Recueil des Cours de l'Academie de Droit International de la Haye, Volume 317 (2005), pp. 9-312

Horizonte: Del Rey. 2006.

The Humanization of Consular Law: The Impact of Advisory Opinion No. 16 (1999) of the Inter-American Court of Human Rights on International Case-Law and Practice. Chinese Journal of International Law, Vol. 6, Issue 1, pp. 1-16, 2007

Casella, Paulo Borba. Fundamentos do Direito Internacional Pós-Moderno. São Paulo: Quartier Latin. 2008.

CASsese, Antonio. Internacional Law. $2^{\text {nd }}$ Edition. New York: Oxford University Press. 2005.

CHARNEY, Jonathan I. Is international law threatened by multiple international tribunals? Recueil des Cours de l'Academie de Droit International de la Haye, Vol. 271 (1998), pp. 101-382.

Corell, Hans. The Role of Public International Law and the ICJ in a Changing World. Freedom from Nuclear Weapons through Legal Accountability and Good Faith. A Conference Report. 31 de Julho de 06. George Farebrother for the World Court Coalition. Russell Press Ltd., 2007, pp. 12-22.

Dallari, Pedro B. A. Tratados internacionais na Emenda Constitucional 45. In: Tavares, André Ramos; LenZA, Pedro; Alarcón, Pietro de Jesús Lora, Coords Reforma do judiciário: analisada e comentada: emenda constitucional 45/2004. São Paulo: Ed. Método, pp. 83-98. 2005.

2003.

Constituição e Tratados Internacionais. São Paulo: Saraiva, 
DAMROSCH, Lori Fisler. Enforcing international law through non-forcible measures. Recueil des Cours

FELdMAN, David. Monism, dualism and constitutional legitimacy. Australian Year Book of International Law, Vol. 20, 1999, pp. 105-126.

HARRIS, Hadar. We are the world - or are we? The United States conflicting views on the use of international law and foreign legal decisions. Human Rights Brief. Washington. v.12. n. 3. p. 5-8. 2005.

Guillaume, Gilbert. Enforcement of Decisions of the International Court of Justice, in Jasentuliyana, N., Ed., Perspectives on International Law, London, Kluwer Law International, 1995.

The proliferation of international judicial bodies: The outlook for the international legal order. Speech by His Excellency Judge Gilbert Guillaume, President of the International Court of

Justice,

to the Sixth Committee of the General Assembly of the United Nations, October $27^{\text {th }}, 2000$. Disponível online em: <http://www.icjcij.org/presscom/index.php?p1=6\&p2=1\&pr=85\&search=\%22nagymaro s\%2>

Henkin, Louis. International Law: Politics, Values and Functions. General Course on Public International Law. Recueil des cours, Vol. 216, issue IV, pp. 9-416, 1989.

KosKenNIEMI, Martti (finalization). Fragmentation of International Law: Difficulties Arising from the Diversification and Expansion of International Law. Report of the Study Group of the International Law Commission. United Nations General Assembly A/CN.4/L.682. 13 April 2006.

LePard, Brian D; KoH, Harold Hongju; Teson, Fernando R; Charlesworth, Hilary. Why obey International Law? - theories for managing conflicts with municipal law. American Society of International Law. Proceedings of the Annual Meeting. January $1^{\text {st }}$, 2003, pp. 111-123.

LAUTERPACHT, E.. The international protection of human rights. Recueil des Cours, no I, Vol. 70, pp. 01-108, 1947.

The development of the law of international organization by the decisions of international tribunals. Recueil des Cours, no. IV, pp. 377-478, Volume 152, 1976.

Llamzon, Aloysius P. Jurisdiction and Compliance in Recent Decisions of the International Court of Justice. The European Journal of International Law Vol. 18, no.5, 2008;

Medeiros, Antônio Paulo Cachapuz de. O Poder de celebrar Tratados: competência dos poderes constituídos para a celebração de tratados a luz do direito internacional, do direito comparado e do direito 
constitucional brasileiro. Tese de Doutorado sob a orientação do Prof. Dr. Luiz Olavo Baptista. Faculdade de Direito da Universidade de São Paulo, 1995.

Mello, Celso D. de Albuquerque. Curso de Direito Internacional Público. $15^{\text {a }}$ Ed. Vol. 1. Rio de Janeiro: Renovar, 2004.

MERON, Theodor. International Law in the Age of Human Rights: General Course on Public International Law. Recueil des Cours, pp. 9-489, Vol. 301, 2003.

MuRPhy, Sean D. Does International Law obligate States to open their national courts to persons for the invocation of treaty norms that protect or benefit persons? In: SLOSS, David, Derek Jinks, eds. The role of domestic courts in treaty enforcement: a comparative study. Cambridge University Press, Forthcoming; GWU Law School Public Law Research Paper No. 438; GWU Legal Studies Research Paper No. 438. 2008.

Pedroso, Fernando de Almeida. Processo Penal. O direito de defesa: repercussão, amplitude e limites. $3^{\text {a }}$ Edição. São Paulo: Revista dos Tribunais, 2001.

Piovesan, Flavia. Direitos Humanos e o Direito Constitucional Internacional. $6^{\text {a }}$ Edição. São Paulo: Saraiva, 2006.

Temas de direitos humanos. 2.ed. São Paulo: Max Limonad, 2003.

Piovesan, Flávia. (Org.); IKAwA, Daniela (Org.). Direitos Humanos Fundamento, Proteção e Implementação. Perspectivas e Desafios Contemporâneo. Curitiba: Juruá, 2007.

REISMAN, W. Michael. The supervisory jurisdiction of the International Court of Justice: international arbitration and international adjudication. Recueil des Cours, Vol. 258, pp. 9-400, 1996.

Ramos, André de Carvalho. Direitos Humanos em Juízo. São Paulo: Max Limonad, 2001.

Direitos dos Estrangeiros no Brasil: imigração, direito de ingresso e os direitos dos estrangeiros em situação irregular. In. SARAMENTO, Daniel; IKAWA, Daniela; PiOVESAN, Flávia (Coord.) Igualdade diferença e direitos humanos. Rio de Janeiro: Lúmen Júris, 2008, pp. 721-746.

Responsabilidade Internacional por Violação de Direitos Humanos. Rio de Janeiro: Renovar, 2004.

Processo internacional de direitos humanos - análise dos sistemas de apuração de violações dos direitos humanos e a implementação das decisões no Brasil. Rio de Janeiro: Renovar, 2002. 
REZEK, Francisco. Tratados e suas relações com o ordenamento jurídico interno: antinomia e norma de conflito. Revista CEJ. Brasilia. v.1. n.2. p.54-9. ago. 1997.

RoDAS, Joao Grandino. Tratados internacionais. Sua executoriedade no direito interno brasileiro. Revista do Curso de Direito da Universidade Federal de Uberlândia. Uberlândia. v.21. n.1/2. p.311-23. dez. 1992.

SePinwall, Amy J., Failures to Punish: Command Responsibility in Domestic and International Law. Michigan Journal of International Law. Vol. 30, 2, 2009, pp. 251-313.

SHAW, Malcon. International Law. $6^{\text {th }}$ Edition. New York: Cambridge University Press, 2008.

Schulte, Constanze. Compliance with decisions of the International Court of Justice. Oxford; New York: Oxford University Press, 2004.

Silva, José Afonso da. Curso de Direito Constitucional Positivo. $30^{\text {a }}$ Ed. São Paulo: Malheiros, 2007.

StEINER, Sylvia Helena de Figueiredo. A convenção americana sobre direitos humanos e sua integração ao processo penal brasileiro. São Paulo: Revista dos Tribunais, 2000.

Tavares, André Ramos. Curso de Direito Constitucional. $6^{\text {a }}$ Ed. São Paulo: Saraiva, 2008.

\section{C) Bibliografia diSPONÍVEL ONLINE}

III Conferência "Brasileiros no Mundo". Rio de Janeiro, 2 e 3 de dezembro de 2010. Ata Consolidada de Reivindicações das Comunidades Brasileiras no Exterior. Decreto no. 7.214 de 15 de Junho de 2010, art. 3을 parágrafo $7^{\circ}$ : "O Ministério das Relações Exteriores e os demais órgãos envolvidos apresentarão anualmente, tendo como base a Ata Consolidada de demandas da comunidade, balanço das ações governamentais implementadas em benefício das comunidades brasileiras no exterior." Ministério das Relações Exteriores Subsecretaria-Geral das Comunidades Brasileiras no Exterior Departamento Consular e de Brasileiros no Exterior. Disponível online em: $<$ http://sistemas.mre.gov.br/kitweb/datafiles/BRMundo/ptbr/file/Ata_Consolidada_III_CBM_dez_2010\%5B1\%5D\%5B1\%5D.pdf $>$ (primeiro acesso em 06/12/2010).

Atos internacionais. PRÁticA DiPlomática BRASILEIRA. MANUAL DE PROCEDIMENTOS. Ministério das Relações Exteriores. Divisão de Atos Internacionais. Brasília, maio de 2008. Disponível online em: 
<http://www2.mre.gov.br/dai/PraticaDiplomaticaBrasileira.pdf> (acesso em janeiro de 2011).

BRASILEIRAS E BRASILEIROS NO EXTERIOR : informações úteis - Brasília. Ministério do Trabalho e do Emprego, CGIg, Brasília, 2007. 72 p. Disponível online em: < http://sistemas.mre.gov.br/kitweb/datafiles/BRMundo/ptbr/file/Brasileiros_no_Exterior_Cartilha_2008.pdf> (acesso em 06/11/2010).

BrasileIros NO Mundo. Estimativas. Subsecretaria Geral das Comunidades Brasileiras no Exterior (SGEB), do Ministério das Relações Exteriores. Departamento Consular e de Brasileiros no Exterior - DCB. Divisão de Assistência Consular - DAC. Segunda Edição. Setembro de 2009. Disponível online em: http://sistemas.mre.gov.br/kitweb/datafiles/BRMundo/ptbr/file/Brasileiros \%20no\%20Mundo\%202009\%20-\%20Estimativas\%20-\%20FINAL.pdf.

CHARNEY, Jonathan I. The impact on the international legal system of the growth of international courts and tribunals. Materials and Publications. NYU Journal of International Law and Politics. Disponível online em: $<$ http://www.pict-pcti.org/publications/PICT_articles/JILP/Charney.pdf> (acesso em 29/09/2010).

DAvis, Lynn W. et al., The Changing Face of Justice: A Survey of Recent Cases Involving Courtroom Interpretation, 7 Harv. Latino L. Rev. 1, Spring 2004. Disponível online em: <http://www.law.harvard.edu/students/orgs/llr/vol7/davis.pdf $>$.

DufFy, Edward. The Avena Act: An Option To Induce State Implementation of Consular Notification Rights After Medellín. $<$ http://legalworkshop.org/2010/09/13/the-avena-act-an-option-to-inducestate-implementation-of-consular-notification-rights-after-medellin $>$, acesso em: $\quad(21 / 03 / 2011)$.

InTERnATIONAL LAW COMMISSION. TeXts, InSTRUMENTS AND FinAl REPORTS. CONSUlar INTERCOURSE AND IMMUNITIES. Draft Articles on Consular Relations with Commentaries, 1961. Disponível online em: $<$ http://untreaty.un.org/ilc/texts/instruments/english/commentaries/9_2_1 961.pdf>.

INTERNATIONAL LAW COMMISSION. Consular Intercourse and Immunities. Summary. Disponível online em: < http://untreaty.un.org/ilc/summaries/9_2.htm>.

Hamilton, Alexander. The Federalist. 1787. Disponível online em: $<$ http://www.foundingfathers.info/federalistpapers/fedi.htm>

JaMes, Anne e Mark Warren. A Universal Safeguard: Providing Consular Assistance to Nationals in Custody. The International Justice Project. Disponível online em: $<$ http://www.internationaljusticeproject.org/pdfs/GenericVCCRprint.pdf $>$ 
James, Anne, Joanne Cecil \& Mark Warren. Equal Protection: Consular Assistance and Criminal Justice Procedures in the USA. The International Justice Project. Disponível online em: $<$ http://www.internationaljusticeproject.org/pdfs/Equal_Protection_final_ 2005.pdf>

JAY, John. The Powers of the Senate. Independent Journal. The Federalist. Nr. 64. Wednesday, March 5, 1788. Disponível online em: $<$ http://www.constitution.org/fed/federa64.htm> (acesso em 02/02/2010).

Posner, Eric A. e Figueiredo, Miguel de. Is the International Court of Justice Biased? University of Chicago. Law \& Economics, Olin Working Paper, Nr 234. December, 2004. p. 02. The Chicago Working Paper Series Index: Disponível online em: <http /Lawecon/index.html://www.law.uchicago.edu>. Social Science Research and at the Network Electronic Paper Collection: Disponível online em: <http://ssrn.com/abstract=642581>.

RoBledo, Juan Manuel Gómez. United Nations Conference on Consular Relations. Historical Context. Vienna, April 24th, 1963. Disponível online em: <http://untreaty.un.org/cod/avl/ha/vccr/vccr.html $>$.

Scheltema, Heko. The Fragmentation of International Law: Framing the Debate. European University Institute. February 20th, 2010. Disponível online em: $<$ http://papers.ssrn.com/sol3/papers.cfm?abstract_id=1581425>, (acesso em 01/10/2010).

United Nations CONFERENCE on CONSUlar Relations Vienna A/CONF.25/16. Official Records. Volume I: Summary records of plenary meetings and of the meetings of the First and Second Committees. Vienna, March $4^{\text {th }}-$ April 22 2 1963. Disponível online em: $<$ http://untreaty.un.org/cod/diplomaticconferences/consrelat1963/vol/english/vol_I_e.pdf>.

United Nations Conference on Consular Relations. A/CONFJS/16/Add.1. Official Records. Volume II: Annexes Vienna Convention on Consular Relations Final Act Optional Protocols Resolutions. Vienna, March $4^{\text {th }}$ April 22 nd $1963 . \quad$ Disponível online em: $<$ http://untreaty.un.org/cod/diplomaticconferences/consrelat1963/vol/english/vol_II_e.pdf>.

WILCOX, Elizabeth R., Ed. Digest of United States Practice in International Law, Digest. Chapter 02.INDD, Oxford University Press, 2008, disponível online em: <http://www.state.gov/documents/organization/138513.pdf>.

\section{JURISPRUdÊNCIA INTERNACIONAL CitAdA}


International Court of Justice. The Vienna Convention on Consular Relations (Paraguay v. United States of America), Provisional Measures, Order of 9 April 1998, I.C.J. Reports 1998, p. 248 (Breard).

International Court of Justice. The Vienna Convention on Consular Relations (Paraguay v. United States of America). Order of 10 November 1998, I.C.J. Reports 1998, p. 426 (Breard).

InTERnAtional COURT OF JUSTICE. LaGrand (Germany v. United States of America). Judgment, I.C. J. Reports 2001, p. 466.

International Court of Justice. Avena and Other Mexican Nationals (Mexico v. United States of America). Judgment, I.C.J. Reports 2004, p. 12.

INTERNATIONAL COURT OF JUSTICE Request for Interpretation of the Judgment of 31 March 2004 in the Case concerning Avena and Other Mexican Nationals (Mexico v. United States of America) (Mexico v. United States of America). ICJ Reports of Judgments, Advisory Opinions and Orders, 19/01/2008.

International Court of Justice. United States Diplomatic and Consular Staff in Tehran (United States of America $v$. Iran). Reports of Judgments, Advisory Opinions and Orders, Judgment of May $24^{\text {th }} 1980$.

International Court of Justice. Case concerning the Arrest Warrant of $11^{\text {th }}$ April 2000 (Democratic Republic of the Congo v. Belgium), ICJ Judgement Report, 14 ${ }^{\text {th }}$ February 2002.

Corte Interamericana de Direitos Humanos. Restrições à Pena de Morte (Artigos. 4.2 e 4.4 da Convenção Americana sobre Direitos Humanos. Opinião Consultiva OC-3/83 de 8 de setembro de 1983 . Série A, n. ${ }^{\circ} 3$.

CORTE INTERAMERICANA DE DiREITOS HumANOS. Garantias Judiciais em Estados de Emergência (arts. 27.2, 25 e 8 da Convencão Americana sobre Direitos Humanos). Opinião Consultiva OC-9/87 de 6 de outubro de 1987. Série $\mathrm{A} \mathrm{N}^{\mathrm{o}} .9$

CORTE InTERAmERICANA DE Direitos Humanos. Compatibilidade de um projeto de lei com o artigo 8.2.h da Convenção Americana sobre Diretos Humanos. Opinião Consultiva OC-12/91 de 6 de dezembro de 1991. Série A n. ${ }^{\circ} 12$

CORTE INTERAMERICANA DE DIREITOS HuMANOS. O direito de informação sobre a assistência consular no marco das garantias do devido processo legal. Opinião Consultiva OC n. ${ }^{\circ} 16 / 99$, de $1^{\circ}$ de outubro de 1999 , solicitada pelos Estados Unidos Mexicanos. Serie A n ${ }^{\circ} .16$.

Corte InTERAmericana De Direitos Humanos. Condição Jurídica e Direitos dos Migrantes Indocumentados. Opinião Consultiva OC-18/03, de 17 de 
setembro de 2003, solicitada pelos Estados Unidos Mexicanos. Serie A $\mathrm{n}^{\mathrm{o}} .18$.

\section{D) JURISPRUDÊNCIA NORTE AMERICANA}

Breard v. Greene, 523 U.S. 371 (1998) - Breard v. Greene, Warden - on application for stay and on petition for writ of certiorari to the united states court of appeals for the fourth circuit, April, $14^{\text {th }}, 1998$.

Karl LaGrand v Arizona, 484 US 872 (1987); Walter LaGrand v Arizona, 484 US 872 (1987)

State vs. LaGrand (Walter), 734 P $2 d 563$ (1987); State v LaGrand (Karl), 733 P 2d 1066 (1987).

State of Missouri vs. Holland, 252 U.S. 416 (1920), 252 U.S. 416. State of Missouri vs. Holland, U. S. Game Warden. No. 609. Argued March 2, 1920. Decided April 19, 1920.

Osagiede vs. United States. Johnbull K. Osagiede, Petitioner-Appellant, vs. United States of America, Respondent-Appellee. 07-1131. No. Argued April 1, 2008. September 09, 2008.

Padilla v. Kentucky, 130 S.Ct.1473 (2010). Supreme Court of The United States.

Certiorari to the Supreme Court of Kentucky. No. 08-651. Argued October 13, 2009

- Decided March 31, 2010.

United States Court of ApPeals for the Ninth Circuit, LaGrand v. Stewart, 133 F.3d 1253 (1998), 16 January 1998.

United States Supreme Court, Breard v. Greene, 523 U.S. 371 (1998), 14 April 1998.

United States Supreme Court, Sánchez-Llamas v. Oregon, 548 U.S. 331 (2006), 28 June 2006.

\section{E) Sites de Consulta}

AMNESTY INTERNATIONAL: <http://www.amnesty.org/>

CORTE INTERAMERICANA DE DERECHOS HuMANOS: <http://www.corteidh.or.cr/ >

INTERNATIONAL COURT OF JUSTICE: <www.icj-cij.org>

INTERNATIONAL LAW COMISSION. CONSULAR INTERCOURSE AND IMMUNITIES. $<$ http://untreaty.un.org/ilc/summaries/9_2.htm>

EXECUTED TODAY. < http://www.executedtoday.com/> 
Secretaria da Administração Penitenciária do Estado de SÃo Paulo. Disponível online em: $<$ http://www.sap.sp.gov.br/common/unidprisionais/crn/pen_itai_cabo_pm_marcelo_ pires_da_silva.html>

SubSECRETARIA GERAL DAS COMUNIDADES BRASILEIRAS NO EXTERIOR (SGEB), DO MINISTÉRIO DAS RELAÇÕES EXTERIORES: $<$ http://www.mre.gov.br/index.php?option=com_content\&task=view\&id=1783\&Ite $\operatorname{mid}=351 \#>$

SUPREME COURT OF THE UNITED STATES: < http://www.supremecourtus.gov/>

The InTERnATIONAL Justice PROJECT: http:<//www.internationaljusticeproject.org/> UNITED NATIONS ORGANIZATION: http:<//www.un.org/english/> 
ANEXo I - ORGANOGRAMA DOS CASOS 